Mariane Secco

\title{
Avaliação do potencial terapêutico de células- tronco mesenquimais do cordão umbilical humano associadas ao IGF-1 para Distrofias Musculares Progressivas
}

São Paulo 
Mariane Secco

\title{
Avaliação do potencial terapêutico de células- tronco mesenquimais do cordão umbilical humano associadas ao IGF-1 para Distrofias Musculares Progressivas
}

\author{
Tese apresentada ao Instituto de Biociências da \\ Universidade de São Paulo, para a obtenção de \\ Título de Doutor em Ciências, na Área de \\ BIOLOGIA/GENÉTICA. \\ Orientadora: Profa. Dra. Mayana Zatz
}

Co-orientador: Prof. Dr. Oswaldo Keith Okamoto

São Paulo

2011 


\section{Ficha Catalográfica}

Secco, Mariane

Avaliação do potencial terapêutico de células-tronco mesenquimais do cordão umbilical humano associadas ao IGF-1 para distrofias musculares progressivas

Número de páginas: 207

Tese (Doutorado Direto) - Instituto de Biociências da Universidade de São Paulo. Departamento de Genética e Biologia Evolutiva.

1. Distrofia Muscular 2. Células-tronco Mesenquimais 3. IGF-1

I. Universidade de São Paulo. Instituto de Biociências. Departamento de Genética e Biologia Evolutiva

\section{Comissão Julgadora:}

Prof(a). Dr(a).

Prof(a). Dr(a).

Prof(a). Dr(a).

Prof(a). Dr(a).

Profa. Dra. Mayana Zatz

Orientadora 


\section{Dedicatória}

Dedico essa tese aos meus pais, Irvando e Teresa, por tornarem possível o alcance de todos os meus sonhos, e sempre acreditarem nas minhas escolhas. 


\section{Agradecimentos}

A realização de cada uma das etapas do presente trabalho foi fruto de muito esforço e dedicação. No entanto, nada disso teria sido possível sem o apoio e ajuda de várias pessoas muito especiais. Por isso, serei eternamente grata a cada um de vocês.

A DEUS, pela proteção e amparo e por ter colocado no meu caminho uma Família exemplar e Amigos maravilhosos.

Aos meus pais, Irvando e Teresa, por todo amor que me dedicaram, por serem meus exemplos de vida, luta, coragem e determinação. Pai, Mãe, agradeço sempre a Deus por ter me abençoado com pais tão maravilhosos. Sem o apoio de vocês nada disso teria sido possível!

Ao meu marido maravilhoso, companheiro, amigo, meu porto-seguro, minha paz. Amor, desculpe pela minha ausência em tantos momentos. Sem o seu apoio e compreensão eu não teria conseguido. Te amo demais.

À minha irmã, Andressa, que assim como minha mãe, é meu exemplo de mulher forte, determinada, guerreira, meu exemplo de mãe, de esposa, de amiga. Que sorte a minha ter uma irmã tão maravilhosa. Dessinha, obrigada por me ouvir e me aconselhar sempre.

Ao meu cunhado Alexandre, exemplo de motivação. Xandy, obrigada por cuidar da minha irmã e da Manu.

A nossa Manuella, que com a sua pouca idade ainda não tem noção do quanto representa para cada um de nós. Aiiiiii, como eu te amo Manu.

A GRANDE Soninha, meu anjo-da-guarda. Benção de Deus na minha vida. Muito obrigada por tudo. 
Muito obrigada a toda minha Família e Amigos, por estarem presentes em todos os momentos da minha vida.

Em especial, agradeço aos meus padrinhos, Vaneide e Cuca (in memoriam).

Agradeço especialmente também aos meus primos maravilhosos, pela indescritível infância que tivemos juntos, mas principalmente por ter vocês na minha vida.

Aos meus avós, em especial a minha avó Alzira, que nos olha lá de cima, e certamente continua torcendo por todos nós e vibrando junto com as nossas conquistas. A minha avó Dirce, por ter gasto todas as velas em orações. Além disso, agradeço a ela por ter me ensinado a ter pensamento positivo SEMPRE. Vó, dentre tantas outras coisas, obrigada por me ensinar que "PALAVRA É ORAÇÃO".

Aos meus sogros, Conceição e Raul, e meus cunhados Ana, Paola, Paulinho e Fábio. Meus primos e amigos Lipe e Paty. Muito obrigada pelo carinho, apoio e torcida.

Aos meus sobrinhos lindos, Giulia, Bia e João. Vocês trazem ainda mais alegria e amor para todos nós.

As minhas amigas mais que especiais, Marley, Monica, Lu, Cintia. Grande parte dessa conquista também é de vocês. Obrigada por tudo!

No decorrer da vida científica aprendemos que a execução de ideias depende fundamentalmente do trabalho em equipe. No meu caso, além do trabalho em equipe, eu tive a sorte de fazer AMIGOS. Por isso, agradeço imensamente e divido essa conquista e alegria com todos vocês.

Agradeço especialmente a minha orientadora Mayana Zatz, que sem dúvida teve um papel fundamental no desenvolvimento desse trabalho. 
Mayana, muito obrigada por ter apostado em mim e por ter oferecido um espaço em seu laboratório por todos esses anos. Serei eternamente grata.

Agradeço especialmente também ao Prof. Oswaldo Keith Okamoto, pelas conversas, sugestões, e conselhos que foram fundamentais desde a primeira etapa deste projeto.

Tati, meu agradecimento especial também a você, que foi a primeira a me acolher de braços abertos no laboratório, que acreditou em mim desde o primeiro momento, e sempre torceu pela minha vitória. Muito obrigada por tudo.

Nati e Eder, meu agradecimento mais que especial para vocês. MEUS PARCEIROS. Tenho certeza que ainda vamos viver muito momentos maravilhosos juntos.

Carmão, muito obrigada pelas dicas e ensinamentos. Grande parte desse trabalho não teria sido possível sem a sua ajuda.

Marcos, não tenho palavras para expressar o quanto FOI FENOMENAL trabalhar com você durante todos esses anos. Dentre tantas outras coisas, levo comigo seu exemplo de determinação.

Amanda, Camila, Gabi, Jú, Mayra, Carla, Estela, Helô, muito obrigada pelos momentos de descontração e tantas risadas. Obrigada por todas as saídas gastronômicas. Não sei o que seria de mim sem o dogão da Reitoria, a tapioca, bolos da mãe da Mayra... Foi tudo inesquecível.

A todos os outros colegas e companheiros de laboratório: Toninha, Inês, Luciana, Miguel, Michel, Melinda, Monize, Naila, Nani. Agradeço em especial ao David, por ter me ajudado tanto com a minha avó.

Não poderia deixar de agradecer também aos amigos de outros laboratórios.

Agradeço a todos os amigos do Laboratório de Proteínas Musculares e Histopatologia Comparada, especialmente à Profa. Mariz pela disponibilidade de sempre. Agradeço também em especial à Paula, que sempre tinha ótimos conselhos para me dar. 
Agradeço ainda a todos os amigos do Laboratório de Genética do Desenvolvimento, especialmente à Profa. Dra. Maria Rita Passos Bueno e a Daniela Bueno.

Agradeço a todas as alunas do Prof. Keith, que sempre são tão gentis com todos nós.

Agradeço ainda a todos os funcionários do Genoma, que mantem a estrutura do Centro e nos permitem trabalhar com muito mais conforto. Muito obrigada a todos vocês.

Agradeço a Miriam e a Neide do IPEN, por toda a ajuda e disponibilidade.

Meu muito obrigada também ao Prof. Sérgio Verjovski e ao Yuri Moreira por terem me auxiliado em uma das etapas desse projeto.

À Constância Gotto pelo apoio e conselhos.

Agradeço também quem já passou pelo projeto e atualmente está em outros lugares. Em especial, agradeço a Kelly Bagattini, que sempre foi uma fofa comigo e que me ajudou muito no começo do estágio.

Aos funcionários, professores e amigos do Departamento de Genética e Biologia Evolutiva da USP.

A todas as mães e filhos que doaram o cordão umbilical e fizeram possível a realização deste trabalho.

A FAPESP e CNPq pelo apoio financeiro.

Enfim, agradeço a todos que de uma forma ou de outra me desejaram sucesso, sorte e felicidade durante o desenvolvimento deste estudo. Absorvi todas as coisas boas e desejo tudo em dobro para todos vocês. 


\section{Epígrafe}

"Se eu pude enxergar mais longe,

foi porque subi nos ombros de gigantes."

(Isaac Newton) 


\section{Nota do Autor}

A proposta deste trabalho é a avaliação do potencial terapêutico de células-tronco mesenquimais (MSCs; do inglês mesenchymal stem cells) de cordão umbilical associadas ao fator de crescimento semelhante à insulina (IGF-1; do inglês insulin-like growth factor 1) para terapia de distrofias musculares progressivas.

Esta tese foi organizada no formato de capítulos, sendo o primeiro deles composto por uma introdução geral e objetivos deste estudo (CAPÍTULO 1). Os capítulos seguintes consistem de artigos científicos publicados em revistas internacionais ou em processo de redação/publicação, os quais descrevem os resultados obtidos durante o período de doutoramento. No último capítulo é feita uma discussão geral sobre todos os resultados obtidos (CAPÍTULO 7). Nos anexos encontram-se os trabalhos relacionados com o tema desta tese, também já publicados em revistas internacionais.

A primeira etapa do nosso estudo consistiu na identificação de fontes abundantes e acessíveis de células-tronco. Neste contexto, descrevemos a eficiência no isolamento de MSCs a partir do tecido do cordão umbilical humano (CAPÍTULO 2) e, posteriormente, comparamos o perfil de expressão gênica de MSCs obtidas de sangue e tecido de cordão umbilical (CAPÍTULO 3). Nas etapas seguintes analisamos o potencial miogênico in vitro das MSCs obtidas do cordão umbilical, quando submetidas a dois diferentes protocolos de indução. Primeiramente investigamos o papel dos fatores solúveis liberados pelo músculo distrófico em induzir a diferenciação miogênica de MSCs (CAPÍTULO 4). Esse protocolo nos permitiu entender como o microambiente do músculo distrófico interfere na potencial miogênico de MSCs e contribuiu para a identificação de alguns dos fatores de crescimento e/ou citocinas presentes no músculo e que estariam, possivelmente, relacionados com a miogênese. Dada a relevância do IGF-1 neste processo, posteriormente analisamos o seu papel na diferenciação miogênica in vitro de MSCs (CAPÍTULO 5). Além disso, verificamos a influência do IGF-1 na interação de MSCs com células 
musculares obtidas de pacientes distróficos, quando em co-culturas (CAPÍTULO 5). Por fim, com base nos resultados obtidos a partir dos experimentos in vitro, analisamos se a associação de IGF-1 e MSCs in vivo seria capaz de promover uma melhora funcional no músculo de modelos murinos de distrofias musculares (CAPÍTULO 5 e 6).

Propor uma terapia para as diferentes formas de distrofias musculares requer ultrapassar diversas barreiras. Embora o uso de célulastronco tem se consolidado como uma estratégia terapêutica promissora, os resultados discrepantes obtidos até o momento reforçam a necessidade de otimizar os protocolos dos transplantes celulares, visando aumentar a efetividade da terapia celular para as distrofias musculares. Neste sentido, a ideia da combinação de diferentes abordagens - MSCs e IGF-1 - surgiu com o intuito de potencializar os efeitos das células-tronco no músculo distrófico. Com base nos resultados obtidos a partir dos experimentos do IGF-1 na diferenciação miogênica de MSCs in vitro, a nossa hipótese inicial era que o este fator contribuiria para promover a miogênese de MSCs in vivo. Visto que os resultados obtidos foram contrários a essa suposição, prosseguimos com a investigação de outros mecanismos que poderiam estar envolvidos no reparo do músculo. Enquanto algumas perguntas foram sendo respondidas, outras novas questões foram surgindo e algumas ainda permanecem em aberto como perspectivas para projetos futuros. 


\section{Sumário}

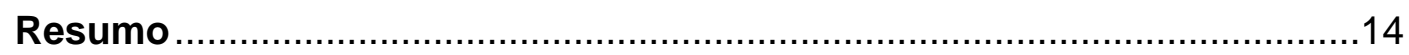

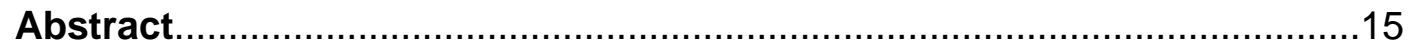

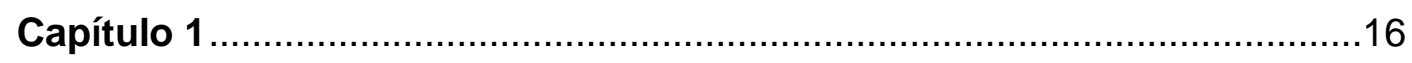

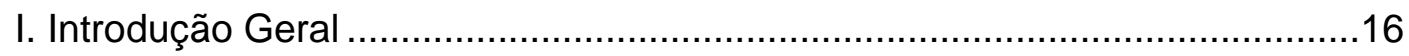

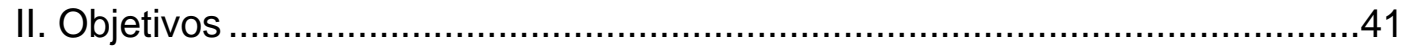

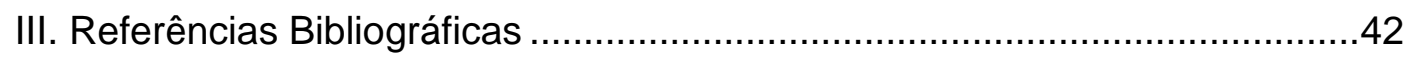

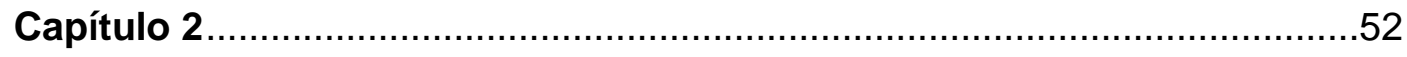

Isolamento de células-tronco mesenquimais de amostras de cordão umbilical

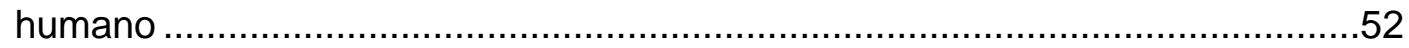

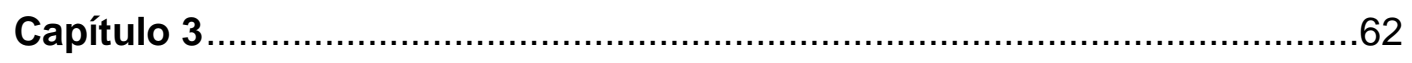

Análise comparativa do perfil de expressão gênica de células-tronco mesenquimais humanas provenientes de sangue de cordão versus tecido de

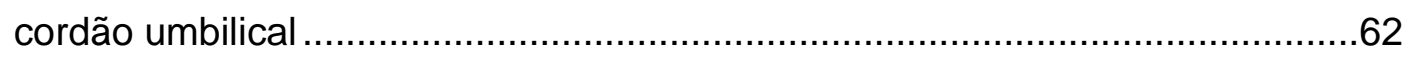

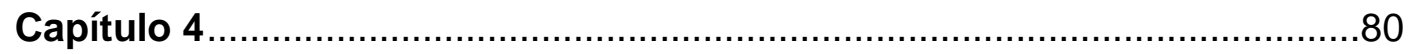

Efeitos dos fatores solúveis liberados pelo músculo distrófico na indução da proliferação e diferenciação miogênica de células-tronco mesenquimais humanas .80

Capítulo 5 106

Potencial terapêutico de células-tronco mesenquimais de cordão umbilical humano associadas ao IGF-1 em um modelo murino de distrofia muscular...106

Capítulo 6. .161

Administração local de IGF-1, em associação a células-tronco mesenquimais humanas, em um modelo murino de distrofia muscular. 161 


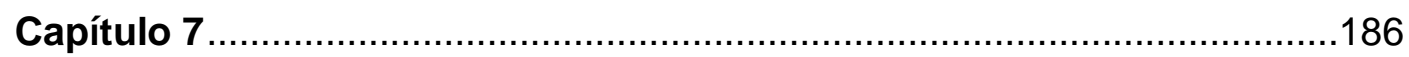

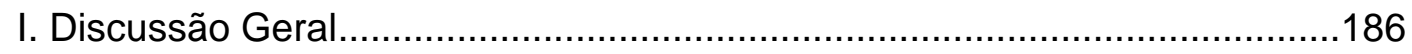

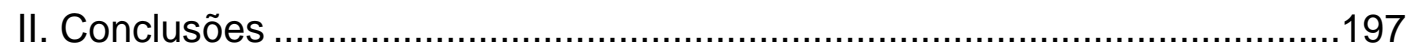

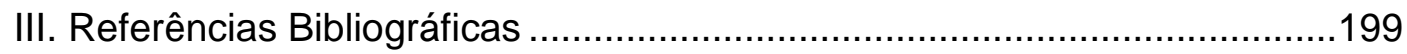

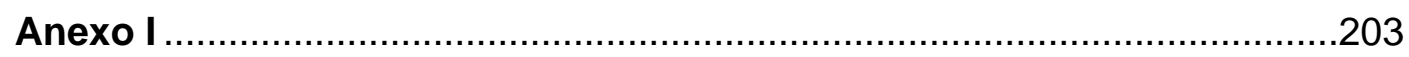

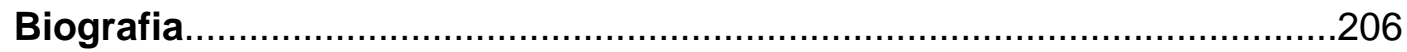




\section{Resumo}

As Distrofias Musculares Progressivas constituem um grupo de doenças genéticas caracterizadas por uma degeneração progressiva e irreversível da musculatura esquelética. As diferentes abordagens terapêuticas propostas para esse grupo de doenças têm como enfoque restaurar a proteína muscular deficiente por meio da terapia celular ou terapia gênica, ou o tratamento dos sinais e sintomas patológicos do músculo pela administração de fármacos e/ou fatores de crescimento. A combinação de diferentes estratégias pode aumentar a eficiência do reparo muscular. Deste modo, este trabalho tem como objetivo principal avaliar o potencial terapêutico das célulastronco mesenquimais (MSCs) associadas ao fator de crescimento semelhante à insulina (IGF-1) para diferentes tipos de distrofias musculares. Inicialmente avaliamos o potencial miogênico de MSCs humanas de cordão umbilical in vitro. Nossos resultados demonstraram que os fatores solúveis liberados pelo músculo distrófico de camundongos $m d x$ foram capazes de induzir a diferenciação miogênica terminal das células-tronco. Além disso, verificamos que o IGF-1, por si só, é capaz de promover a miogênese de MSCs, com mais eficiência que os protocolos de indução padrões. Ainda nos estudos in vitro, demonstramos que MSCs são capazes de interagir com células musculares de pacientes com Distrofia Muscular de Duchenne (DMD) e restaurar a expressão de distrofina, quando cultivadas em meios suplementados com IGF-1. Frente a estes resultados, prosseguimos com os estudos em modelos animais, in vivo, e demonstramos que as MSCs humanas de cordão umbilical e IGF-1, quando administrados conjuntamente por via sistêmica, são capazes de modular a inflamação, reduzir a fibrose, aumentar o reparo muscular e, consequentemente, promover uma melhora clínica significativa do músculo de camundongos LAMA $2^{\text {dy/2j }}$ - modelo murino de Distrofia Muscular Congênita. Cabe ressaltar que as células humanas não foram rejeitadas após administração sistêmica em modelos animais não imunossuprimidos. Esses resultados suportam o potencial uso combinado de MSCs de cordão umbilical humano e IGF-1 no tratamento de distrofias musculares. Contudo, a confirmação destes dados em um modelo animal de grande porte, como os modelos caninos de distrofia muscular, é de extrema importância visando o entendimento dos mecanismos envolvidos no reparo muscular e avaliação de eventuais efeitos adversos, o que pode representar um passo importante para o início dos testes clínicos em pacientes. 


\begin{abstract}
Progressive muscular dystrophies are a clinically and genetically heterogeneous group of disorders caused by the deficiency or abnormal muscle proteins, resulting in progressive degeneration and loss of skeletal muscle function. Strategies for the development of a muscular dystrophy therapy have focused on the possibility of restoring the defective muscle protein by cell therapy or on delivery of growth factors to treat or ameliorate muscular pathology symptoms. Combining both strategies could be a very useful approach to enhance the efficiency of muscle repair. The aim of this study is to evaluate the therapeutic potential of human mesenchymal stem cells (MSCs) from umbilical cord tissue combined with IGF-1 for muscle regeneration. Firstly, we verified the myogenic potential of these cells in vitro. Our results demonstrated that the soluble factors released from $m d x$ dystrophic muscle were able to promote the myogenic differentiation of MSCs. Moreover, we showed that IGF-1 is capable of enhancing considerably the myogenesis of human MSCs from UC in vitro. More interestingly, we showed that IGF-1 enhances the interaction of MSCs and DMD muscle cells in coculture and the restoration of dystrophin expression. Subsequently, our in vivo studies revealed that the association of IGF-1 and MSCs markedly reduced muscle inflammation and fibrosis, and significantly improved muscle strength in LAMA2 ${ }^{d y / 2 j}$ mice, a murine model for congenital muscular dystrophy. It is important to point out that human cells are not rejected even in xenotransplants without immunosuppression. In summary, our results suggest that a combinatorial strategy of both IGF-1 and MSCs could enhance the efficiency of muscle repair and, therefore, should be further tested as a potential therapeutic approach in muscular dystrophies. However it is important to repeat the experiments on canine dystrophic model (GRMD; Golden Retriever Muscular Dystrophy) - in order to enhance our knowledge about the mechanism involved in muscle repair and monitor any eventual long-term side effects, which could represent an important point to start the clinical trial in patients.
\end{abstract}




\section{Capítulo 1}

\section{I - INTRODUÇÃO GERAL}

\section{Distrofias Musculares Progressivas}

As Distrofias Musculares Progressivas (PMDs; do inglês Progressive Muscular Dystrophies) constituem um grupo heterogêneo de doenças hereditárias caracterizadas por degeneração progressiva e irreversível da musculatura esquelética. Atualmente foram descritas mais de 40 formas de PMDs que diferem entre si quanto à idade de manifestação dos primeiros sinais e sintomas, velocidade de progressão da doença, gravidade e localização preferencial das lesões, dentre outros sinais (Emery et al., 2002).

Em geral, as mutações que geram as distrofias estão de alguma forma relacionadas com a organização do complexo de glicoproteínas associadas à distrofina (DGC; do inglês Dystrophin-associated Glicoprotein Complex), localizado na porção interna do sarcolema (FIGURA 1; Jones et al., 1998; Ehmsen et al., 2002). O complexo DGC é considerado essencial para a manutenção da função muscular, porque promove a interação entre o citoesqueleto e a matriz extracelular. A ausência ou deficiência de uma das proteínas desse complexo causa instabilidade da membrana da célula muscular e estresse mecânico associado à contração, resultando na degeneração progressiva das fibras musculares (Petrof et al., 1993; Jones et al., 1998; Rando et al., 2001; Ehmsen et al., 2002; Dalkilic and Kunkel, 2003). Distrofia Muscular de Duchenne (DMD; do inglês Duchenne Muscular Dystrophy) e Becker (BMD; do inglês Becker Muscular Dystrophy) são causadas por mutações no gene da distrofina. Mutações na laminina- $\alpha 2$, por sua vez, causam a Distrofia Muscular Congênita tipo 1A (CMD; do inglês Congenital Muscular Dystrophin). Muitas das mutações nos genes do complexo DGC, incluindo mutações na disferlina, afetam a musculatura dos membros e do tronco 
proximal sendo denominadas de Distrofias Musculares do tipo Cinturas (LGMD; do inglês Limb-Girdle Muscular Dystrophy), o grupo mais heterogêneo das distrofias (Passos-Bueno et al., 1999; Zatz et al., 2000; Zatz et al., 2003).

Em biópsia muscular, os achados histológicos comuns a todas as PMDs consistem em variação no calibre das fibras musculares, áreas de necrose, invasão de células inflamatórias e reposição do tecido muscular por tecido adiposo e/ou tecido conjuntivo (Emery et al., 2002)

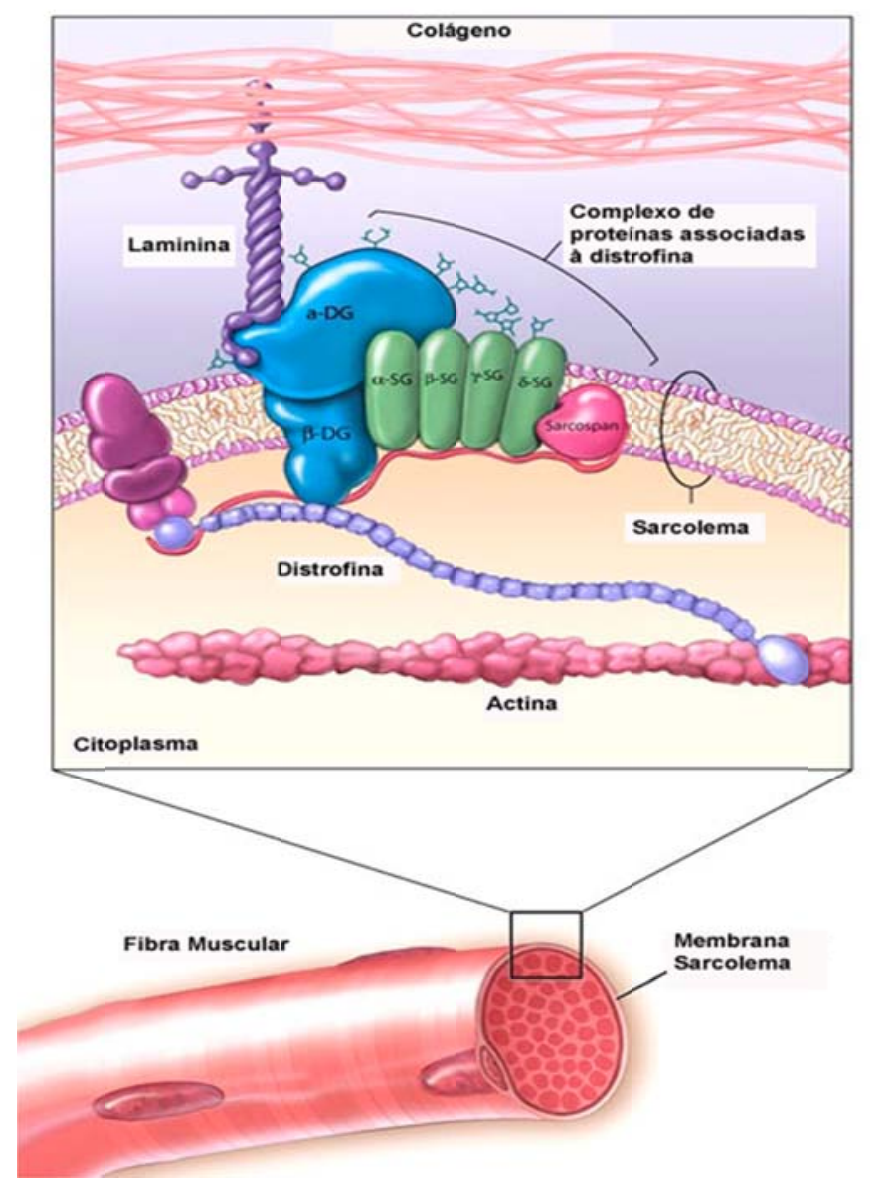

FIGURA 1 - Complexo de Glicoproteínas associadas à Distrofina. Representação esquemática mostrando a interação da distrofina com proteínas citoplasmáticas, transmembrana e extracelulares no músculo esquelético (Modificado a partir de Lydia Kibiuk). 


\subsection{Distrofia Muscular de Duchenne}

Dentre as diferentes miopatias genéticas, a Distrofia Muscular de Duchenne (DMD), é a mais grave e comum, com incidência de um em cada 3.500 nascimentos vivos do sexo masculino (O'Brien and Kunkel, 2001).

A causa primária da doença consiste de mutações no gene da distrofina, localizado no braço curto do cromossomo $X$, que codifica para uma proteína integrante do sarcolema, responsável por ancorar as proteínas do citoesqueleto às proteínas presentes na membrana plasmática (FIGURA 1; Kunkel et al., 1985; Blake et al., 2002; Van Deutekom \& Van Ommen, 2003; Vainzof \& Zatz, 2003). Em seres humanos, a importância do funcionamento da distrofina no músculo esquelético é demonstrada pela grave patologia que ocorre em sua ausência. Na maioria dos casos, os sinais clínicos iniciam-se entre 3-5 anos de idade, caracterizados por níveis séricos aumentados da enzima creatina quinase, pseudo-hipertrofia das panturrilhas, quedas frequentes e dificuldade em correr e subir escadas. Com a progressão da doença, ciclos repetitivos de degeneração superam a capacidade regenerativa do tecido muscular, causando sua substituição por tecido conjuntivo e adiposo. O confinamento em cadeira de rodas se dá em torno dos 10 a 12 anos de idade e, sem cuidados especiais, os afetados raramente sobrevivem após os 20 anos (Blake et al., 2002; Van Deutekom \& Van Ommen, 2003).

\subsubsection{Distrofina e o Complexo Glicoproteico Associado à Distrofina}

Em 1985 o gene responsável pela DMD foi localizado no braço curto do cromossomo X (Xp21). Com 2,3 megabases (Mb), o gene DMD é o maior gene humano já caracterizado (Kunkel et al., 1985). É constituído por 79 éxons, sendo transcrito em um RNA mensageiro (mRNA) de 14 kilobases (Kb). Após a localização do gene e sua clonagem em 1987, descobriu-se que o produto do gene é a distrofina, uma proteína de 3685 aminoácidos e massa molecular de 
427 kilodaltons $(\mathrm{kDa})$, localizada na face citoplasmática da membrana das fibras musculares esqueléticas e cardíacas (Hoffman et al., 1987).

A maioria dos afetados pela DMD apresentam uma mutação que altera a fase de leitura do mRNA (frame-shifting) do gene da distrofina, causando a produção de uma proteína truncada que é rapidamente degradada na célula muscular. Dentre as mutações que causam DMD 60\% são deleções, 5-6\% duplicações e mutações de ponto nos casos restantes (Koenig et al., 1987). Mutações que mantêm o quadro de leitura da distrofina, gerando uma proteína comprometida, mas parcialmente funcional, são responsáveis pela Distrofia Muscular de Becker (BMD), alélica à DMD (Koenig et al., 1989). A incidência da BMD é cerca de 10 vezes menor que a da DMD, ocorrendo um caso a cada 30 mil nascimentos do sexo masculino. Os sintomas e sinais da BMD são semelhantes aos da DMD, mas consideravelmente mais leves. $O$ início de manifestação é mais tardio e a evolução clínica da doença é mais lenta. Além disso, a velocidade de progressão da patologia é extremamente variável, podendo haver, em uma mesma família, afetados com diferentes graus de comprometimento muscular.

Além da manutenção do quadro de leitura do mRNA a gravidade do quadro clínico pode estar associada à localização da deleção. Deleções nas regiões de ligação da distrofina com a actina (região carboxi-terminal) ou na região de ligação com as proteínas da membrana plasmática (região aminoterminal) resultam em um quadro de DMD mais grave. Por outro lado, foram observados casos de deleção de $50 \%$ do gene, restrita à região central (domínio em bastão ou rod domain), associadas a um quadro clínico leve (Vainzof et al., 1993a,b; Passos-Bueno et al., 1994).

A análise da presença de distrofina no músculo pode ser feita por Western blot (WB) e imunofluorescência utilizando anticorpos para região amino-terminal e carboxi-terminal. Os pacientes DMD apresentam ausência de distrofina em WB. Entretanto, se a análise por imunofluorescência é feita com o anticorpo amino-terminal uma marcação positiva parcial de algumas fibras pode 
ser observada, geralmente sem correlação com a gravidade do quadro clínico. Além disso, algumas fibras isoladas distrofina positivas podem ser observadas, denominadas fibras revertentes. A análise de proteínas em pacientes BMD por WB mostra bandas de distrofina com peso molecular alterado ou em quantidade diminuída. A imunoflorescência apresenta uma marcação positiva para distrofina, embora diferente do músculo normal (Hoffman et al., 1988; Vainzof et al., 2003).

Estudos de solubilização da distrofina a partir de frações do sarcolema mostraram que esta proteína interage com várias outras proteínas e glicoproteínas que formam o complexo DGC. Acredita-se que o papel do DGC é estrutural, realizando a ligação entre o citoesqueleto de actina à matriz extracelular, e responsável pela estabilização do sarcolema durante os ciclos de contração e relaxamento da célula muscular, transmitindo a força gerada nos sarcômeros à matriz extracelular. Atualmente, há também evidências de que o DGC esteja envolvido na sinalização celular (Ehmsen et al., 2002; Petrof et al., 1993; Rando, 2001). Como mencionado anteriormente, mutações em outros componentes deste complexo podem acarretar no aparecimento de uma série de doenças musculares, o que ilustra o papel fundamental que ele desempenha na manutenção da integridade do músculo. Alterações na proteína laminina-2, por exemplo, acarretam em uma forma grave de distrofia muscular, a Distrofia Muscular Congênita tipo 1A (CMD1A).

\subsection{Distrofias Musculares Congênitas}

As Distrofias Musculares Congênitas (CMDs) formam um grupo heterogêneo de doenças musculares caracterizado clinicamente pela presença de hipotonia neonatal, atraso no desenvolvimento motor, grau variável de contraturas articulares, e possível associação com anormalidades no sistema nervoso central ou olhos. Pode ocorrer também comprometimento respiratório e da deglutição. A biópsia muscular invariavelmente apresenta alterações 
histopatológicas distróficas. O quadro clínico tende a ficar estável, mas alguns pacientes apresentam uma evolução clínica lenta e progressiva (Dubowitz, 1999).

Aproximadamente $50 \%$ dos casos de CMDs são classificados como forma clássica ou CMD tipo 1A (CMD1A), e são causados por mutações no gene LAMA2 que codifica a cadeia $\alpha 2$ da laminina-2, também conhecida como merosina (Hillaire et al., 1994). A laminina-2 é a principal proteína da matriz extracelular na membrana basal da fibra muscular. Encontra-se ligada às proteínas citoplasmáticas, como a distrofina, por meio de interações com o DGC (FIGURA 1). Forma um heterodímero em forma de cruz, composto por uma cadeia $\alpha 2$ e duas outras cadeias $\beta 1$ e $\gamma 1$. Originalmente com 400 kDa, a cadeia $\alpha 2$ da laminina sofre uma clivagem pós-traducional, originando os fragmentos de 80 e $300 \mathrm{kDa}$.

O gene LAMA2 é composto por 260 kb organizados em 64 éxons, sendo que a parte codificante do RNA mensageiro tem cerca de 9,5 kb. O estudo de mutações no gene LAMA2 mostrou grande heterogeneidade, com presença de deleções e mutações de sentido trocado levando a códons de parada prematuros (Guicheney et al., 1997). A mutação mais frequente, encontrada em cerca de $20 \%$ dos pacientes, é uma deleção de 2pb (20962097). Dado o grande tamanho do gene e a variabilidade de alterações, (grande parte dos pacientes é heterozigoto composto e as mutações pontuais são muito frequentes) a triagem de mutações não é feita rotineiramente nos grandes centros do mundo. Neste caso, o diagnóstico é estabelecido por biópsia muscular e análise imuno-histoquímica utilizando um anticorpo monoclonal comercial que reage com o fragmento de $80 \mathrm{kDa}$ da região Cterminal da proteína. Aproximadamente 95\% das mutações no gene LAMA2 acarretam na deficiência total da proteína, enquanto que os $5 \%$ restantes apresentam deficiência parcial de merosina no músculo, relacionadas às mutações de sentido trocado e pequenas deleções que não alteram o quadro de leitura (Hayashi et al., 1997). 
Clinicamente, o grupo de pacientes merosina-negativos apresenta um fenótipo mais grave; a maioria dos pacientes é incapaz de adquirir marcha independente e o comprometimento respiratório é mais intenso. A maior parte dos afetados por CMD1A não apresenta comprometimento da inteligência, mas apresentam alterações da substância branca do cérebro, observadas por exames tomográficos ou por ressonância magnética (Dubowitz, 1999).

Outras formas mais raras e menos graves de DMC são causadas pela deficiência genética de diversas proteínas. Foram identificados dez genes que causam formas específicas de distrofias congênitas, mas se acredita em uma heterogeneidade ainda maior (Sparks and Escolar, 2011). Atualmente, a classificação internacional reconhece as seguintes categorias de genes responsáveis pela doença:

a. Genes codificadores das proteínas estruturais da membrana basal ou matriz extracelular das fibras musculares esqueléticas: genes do colágeno $\mathrm{VI}$, cadeia laminina- $\alpha 2$ e integrina- $\alpha 7$;

b. Genes codificadores de glicosiltransferases e candidatos que afetam a glicosilação da a-distroglicana, uma proteína de membrana externa da membrana basal: genes POMT1, POMGnT1, fukutin, fukutin-related protein, Large.

c. Selenoproteína-1, que codifica uma proteína do retículo endotelial de função desconhecida.

Existe ainda um grupo heterogêneo de pacientes com CMD, cujo defeito genético, ou a deficiência proteica, ainda não foram identificados. Estes pacientes são incluídos no subgrupo chamado de CMD com merosina presente. 
Embora as bases moleculares das diferentes distrofias musculares estejam bem documentadas, os mecanismos envolvidos na progressão da doença ainda não foram esclarecidos. O avanço nessa área depende do entendimento dos processos envolvidos na regeneração muscular, visando identificar aqueles que podem estar alterados nas PMDs.

\section{Regeneração muscular e a importância do IGF-1}

A musculatura esquelética de mamíferos adultos exibe uma grande capacidade de se adaptar a demandas, como crescimento e lesão. Os processos pelos quais essas adaptações ocorrem são atribuídos a uma pequena população de células mononucleadas - denominadas células satélites ou precursores miogênicos - que residem na periferia das fibras musculares, entre o sarcolema e a lâmina basal. Sem nenhuma perturbação, essas células encontram-se em estado quiescente. Entretanto, em reposta a um estímulo, seja uma lesão do músculo ou uma demanda aumentada de trabalho, as células satélites são ativadas, proliferam, se diferenciam e se fundem a fibras musculares pré-existentes para formas novas miofibras multinucleadas (Chargé \& Rudnicki, 2004).

Apesar de certas peculiaridades, o processo de reparo do músculo nitidamente recapitula os eventos fundamentais do desenvolvimento embrionário, pois envolve a ativação de vários genes em comum, incluindo os genes da família Pax - Pax-3 e Pax-7 - e da família de fatores regulatórios miogênicos (MRFs; do inglês Myogenic Regulatory Factors), que consiste de MyoD, Myf5, MRF4 e miogenina. Células satélites quiescentes expressam Pax7. A ativação e proliferação dos precursores miogênicos é marcada pela expressão de Myf5 e MyoD. Miogenina, por sua vez, é expressa mais tardiamente e é associada com a fusão e diferenciação terminal (FIGURA 2; Chargé \& Rudnicki, 2004). 


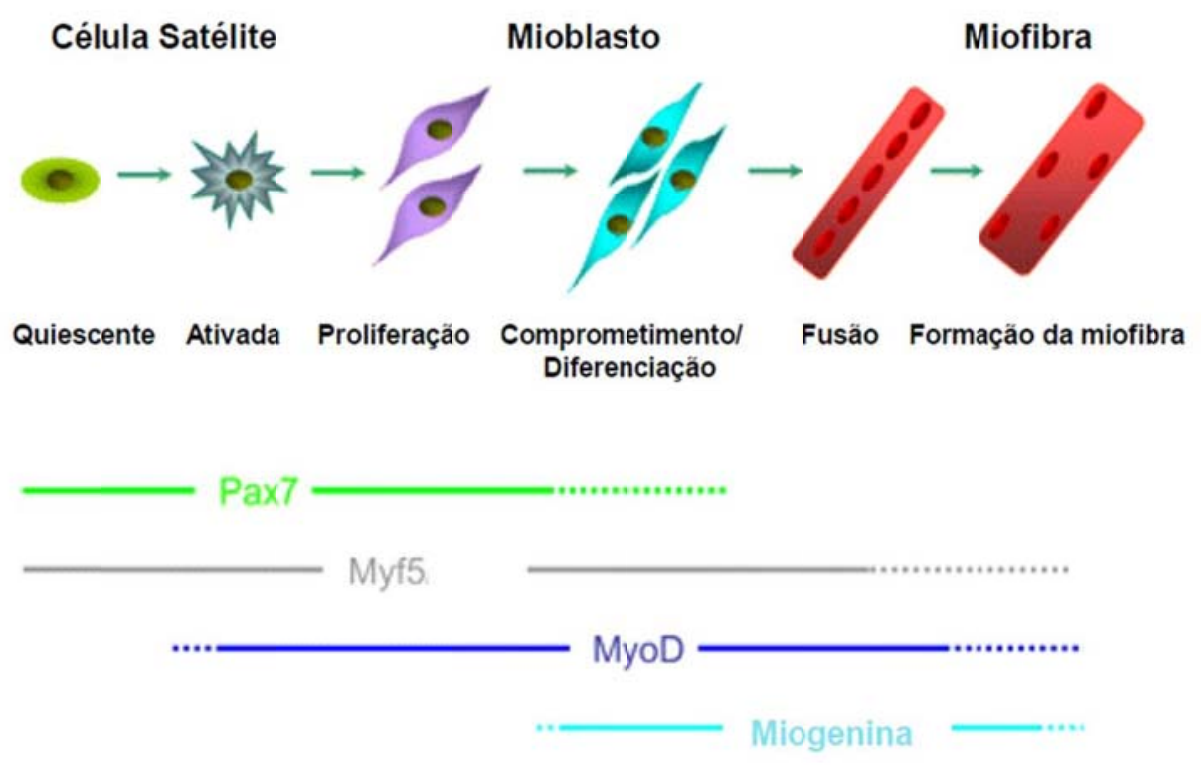

FIGURA 2 - Regeneração Muscular. Representação esquemática mostrando a ativação, proliferação e diferenciação miogênica de células satélites e marcadores típicos de cada estágio do processo de miogênese (modificado a partir de Zammit et al., 2006).

O reparo do músculo é um processo complexo que envolve quatro etapas interdependentes: degeneração, inflamação, regeneração e fibrose (Tidball et al., 1995; Pelosi et al., 2007). O dano tecidual inicia uma invasão rápida e sequencial de células inflamatórias que podem persistir por dias ou meses enquanto a regeneração e/ou reparo do tecido ocorrem. A participação da inflamação é crucial para a ativação do processo de regeneração muscular, mas a sua persistência nem sempre é benéfica para o tecido. Várias evidências demonstram que o processo inflamatório crônico prejudica a regeneração do músculo e, consequentemente, culmina na sua fibrose (Mourkioti \& Rosenthal, 2005; Pelosi et al., 2007). De fato, as interações entre células inflamatórias e fibroblastos são as responsáveis pela produção de citocinas pró-fibróticas, como o TGF- $\beta$ (do inglês Transforming Growth Factor- $\beta$ ), principal regulador da 
fibrose em diversas condições patológicas. Na musculatura esquelética, a cascata fibrogênica também é iniciada por TGF- $\beta$ (Bernasconi et al., 1995; Gosselin et al., 2004). Estudos prévios mostraram que essa citocina impede a expressão de MyoD e inibe a miogênese de células satélites, enquanto induz a sua diferenciação para miofibroblatos (Tidball, 2005). Para que o reparo do músculo possa ocorrer de forma satisfatória, outros fatores de crescimento e/ou citocinas atuam de forma a modular a inflamação, promover a regeneração e limitar a fibrose. Em especial o fator de crescimento semelhante à insulina (IGF1; do inglês insulin-like growth factor 1) têm sido mostrado por contribuir positivamente em vários processos durante o reparo do músculo (Pelosi et al., 2007; Mourkioti \& Rosenthal, 2005).

No caso de pacientes com PMDs, ciclos repetidos de degeneração/regeneração exaurem o "estoque" de células satélites e, consequentemente, a capacidade regenerativa do músculo é perdida (Laguens et al., 1963; Heslop et al., 2000). Além disso, há indícios de que a inflamação crônica instaurada no músculo distrófico promova um desbalanço entre os fatores pro e anti-fibrogênicos, resultando na substituição do tecido muscular por tecido conjuntivo. De fato, vários trabalhos têm demonstrado que os níveis de citocinas e quimiocinas pró-inflamatórias e pró-fibrogênicas encontram-se elevados no músculo distrófico gravemente comprometido, o que evidencia sua contribuição para o processo patológico. Por outro lado, os níveis de IGF-1 são elevados em animais distróficos portadores de uma forma clínica mais benigna de distrofia muscular (De Luca et al., 1999; Sakuma et al., 2000; De Lima et al., 2007). Esses achados são um forte indício da sua participação no processo de regeneração do músculo.

O entendimento dos mecanismos envolvidos no processo de reparo muscular é de extrema importância, uma vez que eles podem ser manipulados de forma a aumentar a eficiência da regeneração muscular e diminuir a fibrose em casos patológicos como nas distrofias musculares. Dada a sua importância nesse processo, o IGF-1 será considerado em mais detalhes a seguir. 


\subsection{Fator de Crescimento Semelhante à Insulina (IGF-1)}

O IGF-1 é um fator de crescimento peptídico, estruturalmente homólogo à insulina, e de fundamental importância nos processos de proliferação e diferenciação de diversos tipos celulares (Mourkioti \& Rosenthal, 2005). Sua síntese se dá principalmente no fígado, mas pode ocorrer em outros tecidos. A maioria dos IGFs em circulação apresentam-se associados a uma família de proteínas transportadoras, conhecidas pela sigla IGFBPs (do inglês insulin-like growth factor binding proteins). Seis IGFBPs foram clonadas e sequenciadas: IGFBP-1 a 6 . As IGFBPs humanas apresentam peso molecular entre 22,8 kDa (IGFBP-6) e 44 kDa (forma glicosilada da IGFBP-3) e exibem grande homologia estrutural entre si. Todas apresentam elevado grau de especificidade e de afinidade para IGFs. Além de aumentarem a sua vida média, as IGFBPs modulam as ações autócrinas, parácrinas e endócrinas do IGF-1, podendo tanto potencializá-las quanto inibi-las. De uma forma geral a associação do IGF-1 com as IGFBPs diminuem sua disponibilidade biológica (Mourkioti \& Rosenthal, 2005).

Na musculatura esquelética o IGF-1 exerce a maioria das suas ações via interação com o receptor IGF-1R e ativação de múltiplas vias de sinalização, entre elas a via da fosfoinositol-3-quinase (PI3K) e das MAP quinases, que resultam na proliferação, diferenciação miogênica e aumento da sobrevida de células precursoras - processos fundamentais para a regeneração muscular (FIGURA 3; Mourkioti \& Rosenthal, 2005). De fato, várias evidências têm mostrado que o IGF-1 contribui ativamente para o reparo do músculo, inclusive em condições patológicas como nas distrofias musculares (De Luca et al., 1999; Sakuma et al., 2000; De Lima et al., 2007). Além de participar da ativação e diferenciação de células satélites, diversos estudos têm mostrado que o IGF-1 é capaz de aumentar o recrutamento de outros progenitores celulares para auxiliar no reparo do músculo (Sacco et al., 2005), modular o processo inflamatório e reduzir a substituição do músculo por tecido adiposo e/ou conjuntivo (Pelosi et al., 2007). Esses efeitos são de extrema importância para amenizar os sintomas clínicos característicos dos diferentes tipos de distrofias 
musculares. Por essa razão, ensaios experimentais pré-clínicos e clínicos visando avaliar o potencial terapêutico do IGF-1 em casos de distrofias musculares tem sido realizados por diversos grupos de pesquisa (Barton et al., 2002; Gehrig et al., 2008; Kumar et al., 2011). No entanto, cabe ressaltar, que o IGF-1 por si só não é capaz de restaurar a expressão das proteínas ausentes nos diferentes casos de distrofias musculares. Por essa razão, a combinação de diferentes abordagens pode constituir uma estratégia terapêutica mais atraente para as distrofias musculares e, portanto, será considerada a seguir.

\section{IGF-1 no Músculo Esquelético}

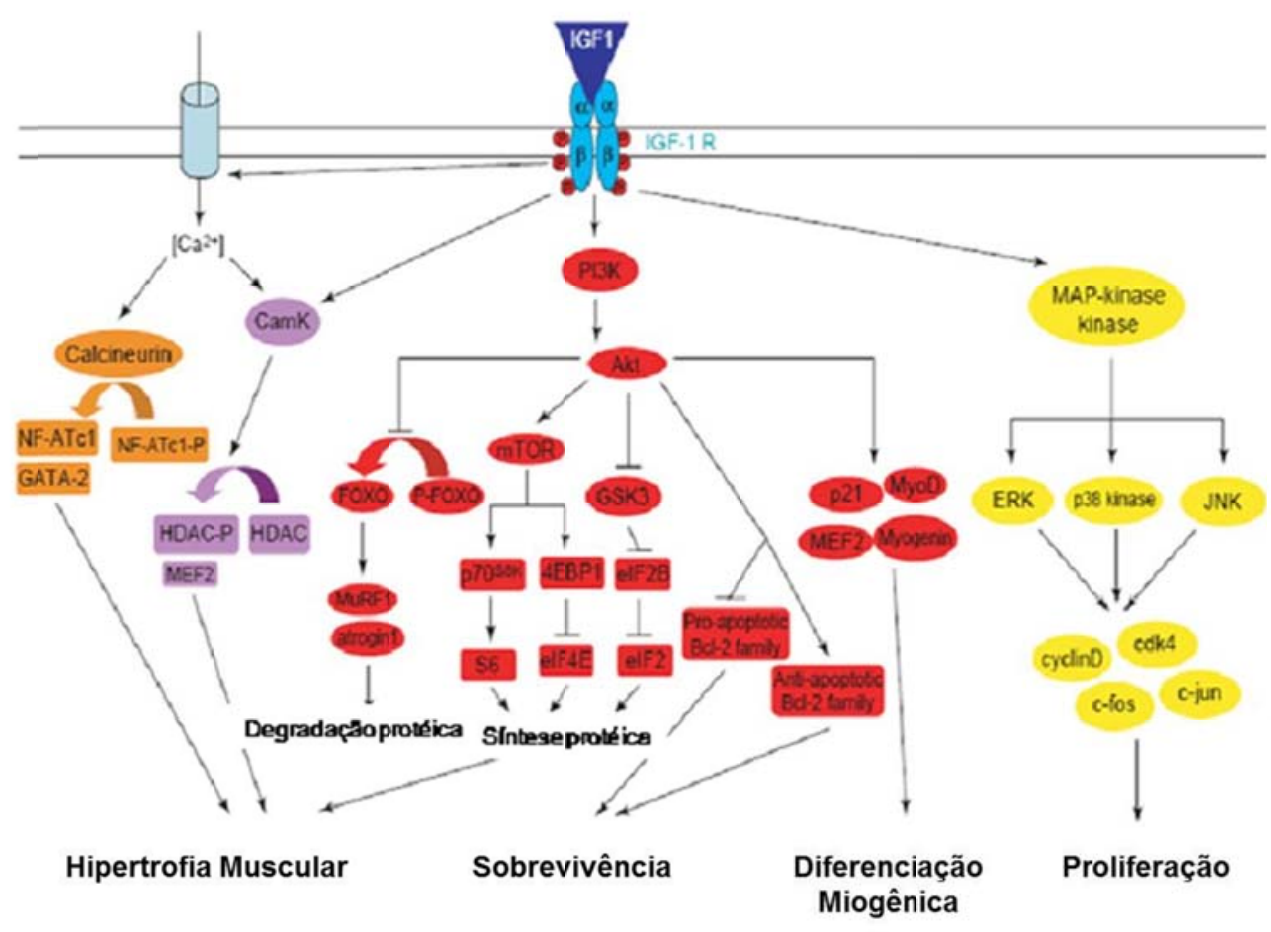

FIGURA 3 - Funções desempenhadas pelo IGF-1 no músculo esquelético. Representação esquemática das vias ativadas pela ligação do IGF-1 no receptor IGF-1R de células musculares esqueléticas (modificado a partir de Mourkioti \&Rosenthal, 2005). 


\section{Modelos animais para as DMPs}

Embora grandes avanços tenham sido obtidos no entendimento das bases moleculares e genéticas das PMDs, nenhum tratamento efetivo para esta doença está disponível. O progresso nesta área depende de modelos animais fiéis à patologia clínica humana, que constituem ferramentas importantes para o melhor entendimento das doenças genéticas e para a investigação de possíveis terapias para as diferentes formas de distrofias musculares.

A descoberta do gene responsável pela DMD e de seu produto proteico, a distrofina, permitiu a identificação de modelos animais homólogos à DMD humana em camundongos, cachorros, gatos e peixe (Bulfield et al., 1984; Sharp et al., 1992; Winand et al., 1994; Bassett and Currie, 2004; Vainzof et al., 2008). Nos humanos e nos cães, o processo de degeneração e fibrose predomina, levando a uma perda progressiva da estrutura e função muscular. Já nos modelos felino e murino, observa-se pouca fibrose e o processo de regeneração supera a necrose do músculo, gerando um fenótipo brando ou ausente de distrofia muscular. Dessa forma, a utilização do modelo murino e felino torna-se limitada, servindo apenas como modelo genético e bioquímico, mas não como modelo clínico-patológico da DMD humana (Partridge, 1991).

Nos últimos anos, cães da raça Golden Retriever portadores de distrofia muscular (GRMD - Golden Retriever Muscular Dystrophy) têm se mostrados importantes para a realização de triagens experimentais, pois suas alterações musculares assemelham-se a patogênese humana, além de possuírem uma massa muscular comparável a dos pacientes distróficos. Os cães afetados possuem uma mutação de ponto $(A>G)$ no sítio 3' de splicing do íntron 6 do gene da distrofina. Por consequência, durante o processamento do RNAm, ocorre a perda total do éxon 7 ou a perda dos 5 nucleotídeos iniciais deste éxon. Ambas variantes de splicing introduzem uma mudança no quadro de leitura e um códon de terminação prematuro, resultando em uma deficiência grave da proteína distrofina no músculo (Sharp et al., 1992). 
O Sapje é o modelo zebrafish para DMD. Surgiu recentemente como um modelo animal promissor para o estudo de distrofias musculares e outras doenças humanas devido ao seu pequeno tamanho, grande número de descendentes (50-350 por semana), rápido desenvolvimento da musculatura esquelética e transparência nas fases embrionária/juvenil. O Sapje apresenta musculatura normal até o dia 2 pós-fertilização, porém seu músculo vai perdendo a organização gradativamente, levando à perda da mobilidade por volta do dia 5 pós-fertilização (Steffen et al., 2007).

Com relação aos modelos murinos, o camundongo $m d x$ tem sido extensivamente estudado. Como na DMD humana, este modelo também apresenta deficiência total da proteína distrofina causada por uma mutação no éxon 23 do gene, que resulta em um códon de parada prematuro. Entretanto, o camundongo $m d x$ não apresenta fraqueza muscular evidente (Bulfield et al., 1984). Alguns pesquisadores sugerem que o fenótipo comparativamente leve deste camundongo pode, em parte, ser atribuído à utrofina, uma proteína relacionada à distrofina, a qual está aumentada nas fibras musculares regeneradas nos animais adultos. Foi demonstrado que camundongos duplamente mutantes para distrofina e utrofina apresentavam um fenótipo muito mais grave e morte prematura (Tinsley et al., 1996, 1998; Squire et al., 2002). Além disso, existem indícios de que estes animais apresentam um microambiente muscular que favorece uma capacidade regenerativa mais efetiva que em humanos (Dimario et al., 1989; De Luca et al., 1999; YablonkaReuveni and Andreson, 2006).

Outros modelos murinos de PMDs apresentam características fenotípicas semelhantes às encontradas em seres humanos. $O$ camundongo SJL, modelo da LGMD2B (disferlinopatia), apresenta uma PMD que afeta primeiramente os músculos proximais. Estes animais apresentam uma mutação em um sítio de splicing do gene que codifica a disferlina, levando a perda do éxon 45 (171 pb) no RNAm. As alterações histopatológicas são discretas e o animal apresenta pouco comprometimento muscular quando jovem; no geral, 
as alterações clínicas são evidentes após 9 meses de idade e, somente quando o animal é erguido pela cauda (Bittner et al., 1999).

Os camundongos $d y / d y$ e LAMA2 $2^{d y / 2 j}$ são modelos naturais da CMD1A. Ambos apresentam degeneração com comprometimento muscular grave e desmielinização do sistema nervoso periférico. O camundongo $d y / d y$, identificado em 1955, apresenta ausência total da proteína merosina no músculo, e o animal sofre de uma forma bastante grave de distrofia muscular, com fraqueza acentuada e reduzido tempo de vida. A mutação neste camundongo ainda não foi localizada. Os camundongos LAMA2 ${ }^{d y / 2 j}$, por sua vez, apresentam deficiência parcial da merosina. A mutação no gene LAMA2 presente nestes animais leva a uma alteração no seu splicing e, consequentemente, a produção de uma proteína truncada sem o domínio VI amino-terminal. Embora seu quadro clínico seja menos grave do que no camundongo $d y / d y$, os animais LAMA $2^{d y / 2 j}$ também apresentam redução na expectativa de vida e um comprometimento muscular bem evidente. No geral, a fraqueza muscular inicia-se em torno de três semanas e meia de idade, afetando primeiramente os membros traseiros, seguido dos axiais e da musculatura dianteira. O músculo esquelético apresenta alterações histopatológicas características do processo de degeneração, incluindo aumento de fibras centronucleadas e quantidade de tecido intersticial, presença de infiltrado inflamatório e variação no calibre das fibras musculares (Sunada et al., 1994, 1995).

Pelo fato de apresentarem um fenótipo diferencial e grave, os camundongos $d y / d y$ e LAMA2 $2^{d y / 2 j}$ têm despertado inestimável interesse no estudo do mecanismo patológico da doença e para o desenvolvimento de estratégias terapêuticas diversificadas.

\section{Estratégias terapêuticas para PDMs}

Diferentes estratégias terapêuticas para as PMDs já foram propostas ou testadas em modelos animais. Dentre elas, o transplante de mioblastos, 
apesar de restaurar a expressão de distrofina em camundongos $m d x$ e pacientes com DMD, ainda apresenta limitações, como baixa distribuição das células após injeção, rejeição imune e baixa sobrevivência celular (Urish et al., 2005; Grounds and Davies, 2007; Peault et al., 2007).

A terapia gênica também tem sido extensivamente testada para PMDs. No caso da DMD, o grande tamanho do mRNA da distrofina constitui um grande empecilho nesta área, pois dificulta a sua manipulação em vetores virais. Entretanto, a criação de miniaturas deste gene (micro e mini-distrofinas) tornou possível sua introdução em vetores virais adenoassociados (AVV) e a realização de ensaios pré-clínicos em camundongos $m d x$ (Wang et al., 2000; Abmayr et al., 2005; Liu et al., 2005). Atualmente, os grandes obstáculos a serem resolvidos envolvem a dose necessária para transdução viral em todo o corpo humano sem causar toxicidade, sua baixa permanência e necessidade de reinjeção sem causar rejeição, e por último, a efetividade da terapia gênica em modelos animais de grande porte (Blankinship et al., 2006; Yuasa et al., 2007; Muntoni and Wells, 2007).

Outras abordagens terapêuticas que têm sido avaliadas em modelos animais incluem drogas inibidoras da via de proteassomas responsáveis pela degradação de proteínas no músculo, a indução da super-expressão de genes relacionados com o reparo muscular, e inibição daqueles associados ao processo de degeneração e fibrose (O’Brien and Kunkel, 2001).

Concomitante aos estudos em modelos animais, já se encontram em andamento estudos clínicos avaliando a segurança da administração de AVV em pacientes com DMD, administração de oligonucleotídeos antisenso para indução de exon skipping e avaliação de drogas que atuariam no mecanismo de tradução do RNA, como por exemplo, a gentamicina (Howard et al., 2004; Wells et al., 2003; O'Brien and Kunkel, 2001; Benchaouir et al., 2007; Chamberlain and Chamberlain, 2010).

A gentamicina é um antibiótico aminoglicosídeo que ignora os chamados códons de parada gerados pela mutação de ponto em pacientes 
com mutações nonsense (Howard et al., 2004). A grande vantagem da gentamicina é que é uma droga muito conhecida e de uso regular em medicina. Por outro lado, as grandes desvantagens são a forma de aplicação, que deve ser injetável, e os efeitos colaterais para a função auditiva (surdez) e renal (insuficiência renal). Além disso, é sabido que os efeitos desse antibiótico só seriam aplicáveis em pacientes que tivessem mutação de ponto, que constituem a minoria dos casos. Em camundongos $m d x$, mais de $20 \%$ de distrofina foi produzida com o uso de gentamicina. No entanto, em estudos realizados com portadores de Duchenne e de Distrofia de Cinturas não foi constatado o restabelecimento da produção da proteína ausente. Não obstante, os pacientes apresentaram redução dos níveis da enzima creatina quinase sérica, o que poderia indicar menor agressão muscular (O’Brien \& Kunkel, 2001).

Outros tratamentos medicamentosos têm sido testados no sentido de prolongar a sobrevida de pacientes com PMDs. Os corticóides são medicamentos utilizados na tentativa de melhorar parcialmente a função pulmonar e diminuir o ritmo de perda da força muscular em pacientes com PMDs. A prednisolona e deflazacort são os corticóides mais usados na prática clínica para tal finalidade. Inclusive, a prednisolona tem sido indicada para crianças portadoras de DMD para manter a deambulação e prevenir ou retardar a escoliose, que é uma deformidade óssea frequente nestes pacientes. No entanto, estas drogas possuem efeitos colaterais importantes, incluindo obesidade, catarata, distúrbio do crescimento, diabetes, hipertensão arterial e osteoporose (Wong and Christopher, 2002; Merlini et al., 2003).

Cabe ressaltar que todos os métodos descritos são experimentais e/ou paliativos e ainda não existe nenhum tratamento efetivo para esse grupo de doenças. Contudo, a utilização de células-tronco tem sido considerada como uma abordagem terapêutica promissora para as diferentes formas de distrofias musculares e, portanto, será considerada em mais detalhes no tópico a seguir. 


\subsection{Células-tronco}

Células-tronco são definidas pela sua capacidade de auto-renovação e diferenciação em múltiplos tipos celulares. Graças a essas características, as células-tronco têm sido extensivamente estudadas como alternativa terapêutica para inúmeras doenças degenerativas e incapacitantes, onde o objetivo imediato é restaurar o funcionamento de tecidos e/ou órgãos por meio da proteção celular ou reposição de células danificadas por células sadias.

De acordo com a sua origem, as células-tronco se classificam em adultas ou embrionárias. Além disso, elas podem ser caracterizadas de acordo com o seu potencial em gerar diferentes tecidos.

As células-tronco embrionárias (CTEs) são definidas como pluripotentes, uma vez que são capazes de se diferenciar em todos os 216 tecidos que compõem o organismo humano. Tradicionalmente, elas são derivadas a partir da massa celular interna de blastocistos provenientes de embriões extranumerários produzidos nas clínicas de fertilização in vitro e doados à pesquisa pelos casais responsáveis, de acordo com as legislações vigentes em cada país (Thomson et al., 1998). Mais recentemente, célulastronco pluripotentes foram produzidas por meio da reprogramação de células adultas. Essas células são conhecidas como células-tronco pluripotentes induzidas (iPS, do inglês induced pluripotent stem cells) e possuem vantagem em relações às CTEs por não levantarem nenhum problema ético na sua obtenção (Klimanskaya et al., 2006; Nakagawa et al., 2007; Takahashi et al., 2007). No entanto, alguns trabalhos publicados mostram que as células iPS possuem diferenças quando comparadas às CTEs (Doi et al., 2009; Urbach et al., 2010). Quanto à aplicação terapêutica de CTEs, além da questão ética, dificuldades técnicas como compatibilidade genética entre doador e receptor e controle da formação de tumores são grandes desafios a serem superados com a pesquisa.

As células-tronco adultas (CTAs), por sua vez, não apresentam os impasses éticos relacionados à pesquisa com CTEs, uma vez que podem ser 
obtidas a partir de diversas fontes biológicas, muitas vezes descartadas após procedimentos cirúrgicos, incluindo-se o cordão umbilical, a medula óssea, polpa dentária, tecido adiposo, trompas de falópio, músculo orbicular do lábio, dentre outros (Zuk et al., 2001; Covas et al., 2003; Seo et al., 2004; Jazedje et al., 2009a; Gronthos et al., 2002; Romanov et al., 2003).

Com relação ao potencial de diferenciação, as CTAs são definidas como:

a. unipotentes: capazes de se diferenciarem em um único tipo celular;

b. oligopotentes: capazes de se diferenciarem em poucos tipos celulares;

c. multipotentes: dão origem a vários, porém limitados, tipos celulares;

Em relação aos tipos de CTAs, duas populações principais se destacam: células-tronco hematopoiéticas (HSCs; do inglês hematopoietic stem cells) e células-tronco mesenquimais (MSCs, do inglês mesenchymal stem cells). Tradicionalmente as HSCs são isoladas da medula óssea, porém, mais recentemente, o mesmo protocolo também está sendo realizado com o sangue do cordão umbilical. As HSCs por definição são capazes de originar toda a linhagem de células sanguíneas e as mesmas podem ser identificadas por uma série de marcadores de superfície celular, como CD34, CD38, CD45, CD133, dentre outros. Ao contrário das HSCs que crescem em suspensão in vitro, as MSCs são cultivadas aderidas nas placas de cultura. MSCs, hoje mais comumente conhecidas como células-tronco estromais mesenquimais, compreendem uma população de células progenitoras multipotentes capazes de diferenciar em vários tipos celulares de origem mesodérmica, incluindo condrócitos, osteócitos e adipócitos (Deans and Moseley, 2000). Além disso, estas células podem ser caracterizadas com os marcadores de superfície celular CD29, CD90, SH2, SH3, SH4, dentre outros.

As células-tronco provenientes do cordão umbilical apresentam um forte atrativo para o uso em terapias celulares devido à presença da fração hematopoiética e mesenquimal. Ademais, o cordão umbilical é geralmente descartado após o parto e sua coleta é realizada por um método simples, 
seguro e não doloroso, não causando nenhum dano para a mãe ou para a saúde do recém-nascido. Cabe ressaltar ainda que as células-tronco do cordão, por serem mais "imaturas", apresentam maior potencialidade e capacidade proliferativa frente a outros tipos de CTAs. Sua fração hematopoiética vem sendo utilizada com sucesso, desde o final da década de 80, para tratar diversas doenças hematológicas. Já o potencial terapêutico da fração mesenquimal vem sendo explorada in vitro e in vivo devido à maior plasticidade destas células em relação à fração hematopoiética.

\subsubsection{Otimizando a Terapia celular para DMPs}

Inicialmente usadas no tratamento de doenças hematológicas e distúrbios auto-imunes, o transplante de HSCs tem sido proposto como alternativa para terapia de outras doenças degenerativas. Entretanto, no caso das distrofias musculares, a maioria dos ensaios pré-clínicos demonstraram que HSCs não foram capazes de restaurar a expressão das proteínas musculares deficientes em níveis clinicamente relevantes (Dell'Agnola et al., 2004; Lapidos et al., 2004; Kuhr et al., 2007). Estudos previamente realizados em nosso laboratório relataram resultados similares ao transplantar HSCs provenientes de sangue de cordão umbilical em cães GRMDs (Zucconi et al., 2011). Recentemente, Kang et al (2010) também publicaram a ineficácia do transplante de HSCs em um paciente com DMD. Assim, abordagens terapêuticas atualmente em experimentação incluem o transplante de outros tipos de células-tronco.

Sampaolesi e colaboradores (2006) demonstraram que célulastronco isoladas dos vasos de biópsias musculares, denominadas mesoangioblastos, foram capazes de promover uma melhora funcional dos animais injetados e restaurar a expressão de distrofina em $70 \%$ das fibras musculares de cães GRMD, após injeções consecutivas via artéria femoral. Apesar do grande impacto do trabalho, este foi criticado internacionalmente devido ao uso de ciclosporina - uma droga anti-inflamatória que poderia ser 
responsável por si só pela melhora clínica - e pelo método subjetivo de avaliação física dos animais.

Um tipo de CTA que vem se destacando em estudos pré-clínicos e clínicos é a MSC. A facilidade de isolamento e cultivo, aliada a propriedades como capacidade de expansão in vitro e de migração in vivo, capacidade multipotente de diferenciação celular, poucas restrições relacionadas às interações com o sistema imunológico e atividade imunossupressora, aumentam o potencial de aplicação de MSCs na área de medicina regenerativa (Kassem et al., 2004; Le Blanc and Pittenger, 2005; Caplan and Dennis, 2006; Caplan and Correa, 2011).

Embora o uso terapêutico das MSCs tem sido extensivamente estudado, os dados apresentados ainda são um tanto quanto controversos. Em relação às distrofias musculares, um dos trabalhos pioneiros com MSCs de medula óssea mostrou que essas células foram utilizadas com sucesso em transplantes para reparo muscular em $m d x$ (Dezawa et al., 2005). Entretanto, a quantidade de MSCs obtidas da punção de medula óssea é pequena (aproximadamente uma célula-tronco por $10^{5}$ células aderentes), o que gera a necessidade de uma grande expansão celular in vitro para obter um número suficiente de células para transplante. Mais recentemente foi relatada a injeção de MSCs de medula óssea, transfectadas com vetores virais expressando PAX3 , em camundongos $m d x$. Ao contrário dos resultados demonstrados anteriormente, neste estudo os autores observaram que, apesar da restauração da expressão da distrofina, não houve melhora clínica da musculatura dos animais (Gang et al., 2009).

Em relação ao possível processo de diferenciação miogênica das células transplantadas no tecido hospedeiro, ensaios pré-clínicos também demonstraram resultados discrepantes. Em camundongos SJL, MSCs humanas obtidas de lipoaspirado injetadas sistemicamente (veia caudal), sem imunossupressão, migraram para a musculatura, se diferenciaram em músculo - comprovado pela presença de proteínas musculares - e melhoraram o 
quadro clínico dos animais afetados (Vieira et al., 2008). Por outro lado, o mesmo experimento realizado com MSCs de cordão umbilical humano mostrou que embora as células-tronco tenham migrado para o músculo dos animais injetados não foi possível detectar a presença de proteínas musculares humanas. Mesmo assim, os animais apresentaram um aparente benefício clínico (Vieira et al., 2010).

No modelo canino GRMD, a injeção de MSCs de polpa dentária humana mostrou resultados promissores após repetidas injeções por via sistêmica (Kerkis et al., 2008). Entretanto, os resultados foram significativamente melhores com MSCs de tecido adiposo humano, injetadas pela artéria femoral; as células injetadas migraram para os músculos distróficos sem causar nenhum efeito colateral e proteínas musculares humanas foram encontradas no músculo dos cães injetados, mesmo após seis meses dos transplantes (Vieira et al., 2011). Corroborando com os resultados obtidos nos modelos murinos, as MSCs de tecido de cordão umbilical humano não mostraram a mesma habilidade para se diferenciar em células musculares e restaurar a expressão de distrofina quando injetadas nos cães GRMD, em comparação com aquelas obtidas de tecido adiposo (Zuncconi et al., 2011). Por outro lado, estudos mais recentes destacaram o potencial miogênico in vivo e in vitro de MSCs de cordão umbilical (Gang et al., 2004; Conconi et al., 2006; Jazedje et al., 2009; Kocaefe et al., 2010).

Apesar dos benefícios clínicos demonstrados nesses trabalhos, as variáveis responsáveis pelo sucesso do transplante de MSCs ainda não foram estabelecidas. A primeira hipótese estudada para justificar os efeitos benéficos da terapia celular é a diferenciação miogênica das células injetadas e, consequentemente, a restauração da expressão da proteína ausente no músculo distrófico. No entanto, os estudos têm mostrado que a recuperação funcional de modelos murinos e/ou caninos de DMD é independente do resgate da expressão de distrofina após transplante de MSCs, o que sugere que a sua diferenciação não é o mecanismo determinístico dos efeitos observados (Gang et al., 2009; English et al., 2010; Gharaibeh et al., 2011; da Justa Pinheiro et al., 
2011; Caplan and Correa, 2011). De fato, estudos publicados recentemente revelaram que a diferenciação miogênica das MSCs in vivo é um evento raro, ocorrendo em apenas pequena proporção, muitas vezes não detectáveis. $A$ maioria dos estudos in vitro também reportou baixa eficiência na indução da miogênese de MSCs (Gharaibeh et al., 2011). Com base nos achados reportados anteriormente, deve-se considerar que o potencial miogênico de MSCs pode variar de acordo com o tecido de onde foram obtidas (Vieira et al., 2010; Gharaibeh et al., 2011). Além disso, é importante ressaltar que o micro ambiente do músculo distrófico também exerce influência na capacidade de diferenciação miogênica das células-tronco transplantadas e, portanto, deve ser avaliado em protocolos de terapia celular para distrofias musculares (Gharaibeh et al., 2011). Não obstante, a diferenciação miogênica de MSCs ainda permanece em debate e, trabalhos que tenham como objetivo a otimização desse processo continuam sendo de extrema importância.

Além da diferenciação miogênica direta das MSCs, outra hipótese cogitada para explicar os efeitos terapêuticos das MSCs em modelos experimentais de distrofias musculares é o efeito indireto como resultado da secreção de citocinas e fatores de crescimento, com ação tanto parácrina quanto autócrina. Sugere-se que os fatores secretados pelas MSCs exerceriam ação anti-apoptótica, anti-fibrogênica e anti-inflamatória, que contribuíram para aliviar os sintomas e sinais clínicos do músculo distrófico (Ichim et al., 2010; English et al., 2010; da Justa Pinheiro et al., 2011; Caplan and Correa, 2011).

O entendimento dos mecanismos de ação envolvidos nos efeitos promovidos pelas MSCs é fundamental para otimizar os benefícios clínicos da terapia celular. Além disso, outras questões essenciais ainda persistem e devem ser investigadas antes que a terapia celular possa se afirmar como uma alternativa de tratamento.

Com relação às MSCs, talvez a preocupação mais consistente seja seu potencial de originar outras linhagens celulares de mesoderme, tais como osso e tecido adiposo. Neste sentido, estratégias para prevenir a diferenciação 
intramuscular das células-tronco injetadas em tipos celulares não desejados, incluem o seu estímulo, ex vivo ou in situ, com fatores relacionados com a indução da miogênese. Idealmente esse estímulo melhoraria seu potencial terapêutico e, simultaneamente, limitaria sua diferenciação em tecidos indesejáveis. Neste sentido, alguns trabalhos têm proposto a indução da superexpressão de genes relacionados com a cascata da miogênese em MSCs, sobretudo MyoD, com o intuito de aprimorar a diferenciação miogênica das células in vitro e in vivo (Gang et al., 2008; Gang et al., 2009; Wagner et al., 2009; Goudenege et al., 2009; Kocaefe et al., 2010; Nitahara-Kasahara et al., 2011).

A manipulação do microambiente da lesão também é de extrema importância visando favorecer as ações diretas e/ou indiretas das MSCs no local da injúria e, consequentemente, otimizar os protocolos de terapia celular (Wagner et al., 2009). No caso das distrofias musculares, em estágios mais avançados da doença, os fatores solúveis liberados na musculatura esquelética em decorrência da inflamação crônica e da substituição do tecido muscular por tecido conjuntivo podem acarretar na indução da diferenciação de MSCs para gordura e/ou tecido conectivo, ou ainda diminuir a sobrevida das células. Além disso, a fibrose que se instaura no músculo distrófico forma uma barreira que dificulta a sua re-população pelas MSCs injetadas. De fato, muitos dos resultados obtidos até o momento demonstraram que as células parecem não tolerar o ambiente pós-transplante e efetivamente regenerar o músculo em quantidades clinicamente relevantes. Neste caso, pode-se presumir que intervenções terapêuticas visando amenizar as alterações secundárias do músculo distrófico - tais como inflamação crônica e fibrose intersticial - são fundamentais para aumentar a efetividade dos transplantes celulares. Tendo em vista a complexidade da doença, é provável que tratamentos mais efetivos resultem de uma combinação de diferentes estratégias terapêuticas.

Considerando os inúmeros papéis desempenhados pelo IGF-1 durante o processo de reparo do músculo - tais como aumento da sobrevida, ativação e diferenciação miogênica de células satélites, modulação da 
inflamação e redução da fibrose (Mourkioti \&Rosenthal, 2005) - pode-se sugerir que a associação de MSCs e IGF-1 constitui uma alternativa atraente para o tratamento das distrofias.

Com base nessas premissas, este trabalho visa avaliar o potencial de MSCs de cordão umbilical humano associadas ao IGF-1, de diferenciar-se em células musculares in vitro e in vivo, restaurar a expressão proteica e a morfologia do músculo distrófico, atenuando os sinais clínicos associados à degeneração muscular. 


\section{II - OBJETIVOS}

O presente estudo teve como objetivo principal avaliar o potencial terapêutico de células-tronco mesenquimais derivadas de tecido de cordão umbilical humano associadas ao IGF-1 em um modelo murino de distrofia muscular. Os objetivos específicos foram:

1. Identificar fontes abundantes e acessíveis de MSCs;

2. Avaliar o potencial miogênico de MSCs de tecido de cordão umbilical humano;

3. Testar a eficiência de diferentes protocolos de indução da miogênese em MSCs de tecido de cordão umbilical humano;

4. Investigar a capacidade dos fatores solúveis liberados pelo músculo distrófico em induzir a diferenciação miogênica de MSCs;

5. Comparar os efeitos dos fatores solúveis liberados pelo músculo de camundongos distróficos $m d x$ e LAMA $2^{d y / 2 j}$ na diferenciação miogênica de MSCs;

6. Quantificar os níveis dos fatores de crescimento IGF-1 e TGF- $\beta$ no músculo de camundongos $m d x$ e LAMA $2^{d y / 2 j}$;

7. Avaliar o papel do IGF-1 na diferenciação miogênica de MSCs humanas de tecido de cordão umbilical in vitro;

8. Avaliar a influência do IGF-1 na interação de MSCs humanas de tecido de cordão umbilical com células musculares in vitro;

9. Avaliar o potencial de MSCs de humanas de tecido de cordão umbilical associadas ao IGF-1, de diferenciar-se em células musculares in vivo, restaurar a expressão proteica e a morfologia do músculo e atenuar os sinais clínicos associados à degeneração muscular em um modelo murino de distrofia muscular. 


\section{III - REFERÊNCIAS BIBLIOGRÁFICAS}

Abmayr, S., Gregorevic, P., Allen, J.M., and Chamberlain, J.S. (2005). Phenotypic improvement of dystrophic muscles by $\mathrm{rAAV} /$ microdystrophin vectors is augmented by Igf1 codelivery. Mol. Ther. 12, 441-450.

Barton, E.R., Morris, L., Musaro, A., Rosenthal, N., and Sweeney, H.L. (2002). Muscle-specific expression of insulin-like growth factor I counters muscle decline in mdx mice. J. Cell Biol. 157, 137-148.

Bassett, D., and Currie, P.D. (2004). Identification of a zebrafish model of muscular dystrophy. Clin. Exp. Pharmacol Physiol. 31, 537-540.

Benchaouir, R. et al. (2007). Restoration of human dystrophin following transplantation of exon-skipping-engineered DMD patient stem cells into dystrophic mice. Cell Stem Cell 1, 646-657.

Bernasconi, P., Torchiana, E., Confalonieri, P., Brugnoni, R., Barresi, R., Mora, M., Cornelio, F., Morandi, L., and Mantegazza, R. (1995). Expression of transforming growth factor-beta 1 in dystrophic patient muscles correlates with fibrosis. Pathogenetic role of a fibrogenic cytokine. J. Clin. Invest. 96, 11371144.

Bittner, R.E. et al. (1999). Dysferlin deletion in SJL mice (SJL-Dysf) defines a natural model for limb girdle muscular dystrophy 2B. Nature Genetics 23, 141142.

Blake, D.J., Weir, A., Newey, S.E., and Davies, K.E. (2002). Function and genetics of dystrophin and dystrophin-related proteins in muscle. Physiological Reviews 82, 291-329.

Blankinship, M.J. et al. (2006). Gene therapy strategies for Duchenne Muscular Dystrophy utilizing recombinant adeno-associated virus vectors. Molecular Therapy, 13, 241-249.

Bulfield, G., Siller, W.G., Wight, P.A., and Moore, K.J. (1984). X chromosomelinked muscular dystrophy (mdx) in the mouse. Proc. Natl. Acad. Sci. U S A 81, 1189-1192.

Caplan, A.I., and Dennis, J.E. (2006). Mesenchymal stem cells as trophic mediators. J. Cell Biochem. 98, 1076-1084.

Caplan, A.I., and Correa, D. (2011). The MSC: an injury drugstore. Cell Stem Cell 9, 11-15.

Chamberlain, J.R., and Chamberlain, J.S. (2010). Muscling in: Gene therapies for muscular dystrophy target RNA. Nat. Med. 16, 170-171. 
Chargé, S.B., and Rudnicki, M.A. (2004). Cellular and molecular regulation of muscle regeneration. Physiol. Rev. 84, 209-238.

Conboy, I.M., Conboy, M.J., Wagers, A.J., Girma, E.R., Weissman, I.L., and Rando, T.A. (2005). Rejuvenation of aged progenitor cells by exposure to a young systemic environment. Nature 433, 760-764.

Conconi, M.T., Burra, P., Di Liddo, R., Calore, C., Turetta, M., Bellini, S., Bo, P., Nussdorfer, G.G., and Parnigotto, P.P. (2006). CD105(+) cells from Wharton's jelly show in vitro and in vivo myogenic differentiative potential. Int. J. Mol. Med. 18, 1089-1096.

Covas, D.T. et al. (2003). Isolation and culture of umbilical vein mesenchymal stem cells. Braz. J. Med. Biol Res. 36, 1179-1183.

Da Justa Pinheiro, C.H., De Queiroz, J.C., Guimarães-Ferreira, L., Vitzel, K.F., Nachbar, R.T., De Sousa, L.G., De Souza-Jr, A.L., Nunes, M.T., and Curi, R. (2011). Local Injections of Adipose-Derived Mesenchymal Stem Cells Modulate Inflammation and Increase Angiogenesis Ameliorating the Dystrophic Phenotype in Dystrophin-Deficient Skeletal Muscle. Stem Cell Rev. [Epub ahead of print].

Dalkilic, I., and Kunkel, L.M. (2003). Muscular dystrophies: genes to pathogenesis. Curr. Opin. Genet. Dev. 13, 231-238.

De Lima, A.R. et al. (2007). Muscular dystrophy-related quantitative and chemical changes in adenohypophysis GH-cells in golden retrievers. Growth Horm. IGF Res. 17, 480-491.

Deans, R.J., and Moseley, A.B. (2000). Mesenchymal stem cells: biology and potential clinical uses. Exp. Hematol. 28, 875-884.

Dell'Agnola, C., Wang, Z., Storb, R., Tapscott, S.J., Kuhr, C.S., Hauschka, S.D., Lee, R.S., Sale, G.E., Zellmer, E., Gisburne, S., et al. (2004). Hematopoietic stem cell transplantation does not restore dystrophin expression in Duchenne muscular dystrophy dogs. Blood. 104, 4311-4318.

Dezawa, M., Ishikawa, H., Itokazu, Y., Yoshihara, T., Hoshino, M., Takeda, S., Ide, C., and Nabeshima, Y. (2005). Bone marrow stromal cells generate muscle cells and repair muscle degeneration. Science 309, 314-317.

De Luca, A. et al. (1999). Higher content of insulin-like growth factor-I in dystrophic mdx mouse: potential role in the spontaneous regeneration through an electrophysiological investigation of muscle function. Neuromuscul Disord 9, 11-18. 
Di Mario, J., Buffinger, N., Yamada, S., and Strohman, R.C. (1989). Fibroblast growth factor in the extracellular matrix of dystrophic (mdx) mouse muscle. Science 244, 688-690.

Doi, A., Park, I.H., Wen, B., Murakami, P., Aryee, M.J., Irizarry, R., Herb, B., Ladd-Acosta, C., Rho, J., Loewer, S., Miller, J., Schlaeger, T., Daley, G.Q., and Feinberg, A.P. (2009). Differential methylation of tissue- and cancer-specific CpG island shores distinguishes human induced pluripotent stem cells, embryonic stem cells and fibroblasts. Nat. Genet. 41, 1350-1353.

Dubowitz, V. (1999). 68th ENMC international workshop: On Congenital Muscular Dystrophy, 9-11, April 1999, Naarden, The Netherlands: Neuromuscul. Disord. 9, 446-454.

Ehmsen, J., Poon, E., and Davies, K. (2002). The dystrophin-associated protein complex. J Cell Sci 115, 2801-2803.

Emery, A.E. (2002). The muscular dystrophies. Lancet 359, 687-695.

English, K., French, A., and Wood, K.J. (2010). Mesenchymal stromal cells: facilitators of successful transplantation? Cell Stem Cell 7, 431-442.

Gang, E.J., Jeong, J.A., Hong, S.H., Hwang, S.H., Kim, S.W., Yang, I.H., Ahn, C., Han, H., and Kim, H. (2004). Skeletal myogenic differentiation of mesenchymal stem cells isolated from human umbilical cord blood. Stem Cells. 22, 617-624.

Gang, E.J., Bosnakovski, D., Simsek, T., To, K., and Perlingeiro, R.C. (2008). Pax3 activation promotes the differentiation of mesenchymal stem cells toward the myogenic lineage. Exp. Cell Res. 314, 1721-1733.

Gang, E.J., Darabi, R., Bosnakovski, D., Xu, Z., Kamm, K.E., Kyba, M., and Perlingeiro, R.C., (2009). Engraftment of mesenchymal stem cells into dystrophin-deficient mice is not accompanied by functional recovery. Exp. Cell Res. 315, 2624-2636.

Gehrig, S.M., Ryall, J.G., Schertzer, J.D., and Lynch, G.S. (2008). Insulin-like growth factor-I analogue protects muscles of dystrophic mdx mice from contraction-mediated damage. Exp. Physiol. 93, 1190-1198.

Gharaibeh, B., Lavasani, M., Cummins, J.H., and Huard, J. (2011). Terminal differentiation is not a major determinant for the success of stem cell therapy - cross-talk between muscle-derived stem cells and host cells. Stem Cell Res. Ther. 2, 31.

Gosselin, L.E., Williams, J.E., Deering, M., Brazeau, D., Koury, S., and Martinez, DA. (2004). Localization and early time course of TGF-beta 1 mRNA expression in dystrophic muscle. Muscle Nerve 30, 645-653. 
Goudenege, S., Pisani, D.F., Wdziekonski, B., Di Santo, J.P., Bagnis, C., Dani, C., and Dechesne, C.A. (2009). Enhancement of myogenic and muscle repair capacities of human adipose-derived stem cells with forced expression of MyoD. Mol. Ther. 17, 1064-1072.

Gronthos, S. et al. (2002). Stem cell properties of human dental pulp stem cells. Journal of Dental Research 81, 531-535.

Grounds, M.D., and Davies, K.E. (2007). The allure of stem cell therapy for muscular dystrophy. Neuromuscular Disorders 17, 206-208.

Guicheney, P., Vignier, N., Helbling-Leclerc, A., Nissinen, M., Zhang, X., Cruaud, C., Lambert, J.C., Richelme, C., Topaloglu, H., Merlini, L., et al. (1997). Genetics of laminin alpha 2 chain (or merosin) deficient congenital muscular dystrophy: from identification of mutations to prenatal diagnosis. Neuromuscul. 7, 180-186.

Hayashi, Y.K., Ishihara, T., Domen, K., Hori, H., and Arahata K. (1997). A benign allelic form of laminin alpha 2 chain deficient muscular dystrophy. Lancet. 349, 1147.

Heslop, L., Morgan, J.E., and Partridge, T.A. (2000). Evidence for a myogenic stem cell that is exhausted in dystrophic muscle. Journal of Cell Science 113, 2299-2308.

Hillaire, D., Leclerc, A., Fauré, S., Topaloglu, H., Chiannilkulchaï, N., Guicheney, P., Grinas, L., Legos, P., Philpot, J., Evangelista, T., et al. (1994). Localization of merosin-negative congenital muscular dystrophy to chromosome $6 q 2$ by homozygosity mapping. Hum. Mol. Genet. 3, 1657-1661.

Hoffman, E.P. et al. (1988). Characterization of dystrophin in muscle-biopsy specimens from patients with Duchenne's or Becker's muscular dystrophy. N. Engl. J. Med. 318, 1363-1368.

Hoffman, E.P., Brown, R.H., Jr. and Kunkel, L.M. (1987). Dystrophin: the protein product of the Duchenne muscular dystrophy locus. Cell 51, 919-928.

Howard, M.T. et al. (2004). Readthrough of dystrophin stop codon mutations induced by aminoglycosides. Annals of Neurology 55, 422-426.

Ichim, T.E., Alexandrescu, D.T., Solano, F., Lara, F., Campion, R. de N., Paris, E., Woods, E.J., Murphy, M.P., Dasanu, C.A., Patel, A.N., Marleau, A.M., Leal, A., and Riordan NH. (2010). Mesenchymal stem cells as anti-inflammatories: implications for treatment of Duchenne muscular dystrophy. Cell Immunol. 260, 75-82. 
Jazedje, T. et al. (2009a). Human fallopian tube: a new source of multipotent adult mesenchymal stem cells discarded in surgical procedures. J. Transl. Med. 7, 46 .

Jazedje, T. et al. (2009). Stem cells from umbilical cord blood do have myogenic potential, with or without differentiation induction in vitro. J. Transl. Med. 7, 6 .

Jones, K.J., Kim, S.S., and North, K.N. (1998). Abnormalities of dystrophin, the sarcoglycans, and laminin alpha2 in the muscular dystrophies. J. Med. Genet. $35,379-386$.

Kang., PB., Lidov, H.G., White, A.J., Mitchell, M., Balasubramanian, A., Estrella, E., Bennett, R.R., Darras, B.T., Shapiro, F.D., Bambach, B.J. et al. (2010). Inefficient dystrophin expression after cord blood transplantation in Duchenne muscular dystrophy. Muscle Nerve. 41, 746-750.

Kassem, M. et al. (2004). Mesenchymal stem cells: cell biology and potential use in therapy. Basic Clin. Pharmacol. Toxicol. 95, 209-214.

Kerkis, I., Ambrosio, C.E., Kerkis, A., Martins, D.S., Zucconi, E., Fonseca, S.A., Cabral, R.M., Maranduba, C.M., Gaiad, T.P., Morini, A.C., et al. (2008). Early transplantation of human immature dental pulp stem cells from baby teeth to golden retriever muscular dystrophy (GRMD) dogs: local or systemic? J. Transl. Med. 6, 35.

Klimanskaya, I. et al. (2006). Human embryonic stem cell lines derived from single blastomeres. Nature 444, 481-485.

Kocaefe, C., Balci, D., Hayta, B.B., and Can, A. (2010). Reprogramming of human umbilical cord stromal mesenchymal stem cells for myogenic differentiation and muscle repair. Stem Cell Rev. 6, 512-522.

Koenig, M., Hoffman, E.P., Bertelson, C.J., Monaco, A.P., Feener, C., and Kunkel, L.M. (1987). Complete cloning of the Duchenne muscular dystrophy (DMD) CDNA and preliminary genomic organization of the DMD gene in normal and affected individuals. Cell. 50, 509-517.

Koenig, M. et al. (1989). The molecular basis for Duchenne versus Becker muscular dystrophy: correlation of severity with type of deletion. American Journal of Human Genetics 45, 498-506.

Kuhr, C.S., Lupu, M., and Storb, R. (2007). Hematopoietic cell transplantation directly into dystrophic muscle fails to reconstitute satellite cells and myofibers. Biol. Blood Marrow Transplant. 13, 886-888.

Kumar, A., Yamauchi, J., Girgenrath, T., and Girgenrath, M. (2011). Musclespecific expression of insulin-like growth factor 1 improves outcome in 
Lama2Dy-w mice, a model for congenital muscular dystrophy type 1A. Hum. Mol. Genet. 20, 2333-2343.

Kunkel, L.M., Monaco, A.P., Middlesworth, W., Ochs, H.D., and Latt, S.A. (1985). Specific cloning of DNA fragments absent from the DNA of a male patient with an X chromosome deletion. Proc. Natl. Acad. Sci. U S A 82, 47784782.

Laguens, R. (1963). Satellite Cells of Skeletal Muscle Fibers in Human Progressive Muscular Dystrophy. Virchows Archiv fur Pathologische Anatomie und Physiologie und fur Klinische Medizin 336, 564-569.

Lapidos, K.A., Chen, Y.E., Earley, J.U., Heydemann, A., Huber, J.M., Chien, M., Ma, A., and McNally, E.M. (2004). Transplanted hematopoietic stem cells demonstrate impaired sarcoglycan expression after engraftment into cardiac and skeletal muscle. J. Clin. Invest. 114, 1577-1585.

Le Blanc, K., and Pittenger, M. (2005). Mesenchymal stem cells: progress toward promise. Cytotherapy 7, 36-45.

Liu, M. et al. (2005). Adeno-associated virus-mediated microdystrophin expression protects young $\mathrm{mdx}$ muscle from contraction-induced injury. Mol. Ther. 11, 245-256.

Merlini, L. et al. (2003). Early prednisone treatment in Duchenne muscular dystrophy. Muscle and Nerve 27, 222-227.

Mourkioti, F., and Rosenthal, N. (2005). IGF-1, inflammation and stem cells: interactions during muscle regeneration. Trends Immunol 26, 535-42.

Muntoni, F., and Wells, D. (2007). Genetic treatments in muscular dystrophies. Curr. Opin. Neurol. 20, 590-594.

Nakagawa, M. et al. (2007). Generation of induced pluripotent stem cells without Myc from mouse and human fibroblasts. Nature Biotechnology 26, 101-106.

Nitahara-Kasahara, Y., Hayashita-Kinoh, H., Ohshima-Hosoyama, S., Okada, H., Wada-Maeda, M., Nakamura, A., Okada, T., and Takeda S. (2011). Longterm Engraftment of Multipotent Mesenchymal Stromal Cells That Differentiate to Form Myogenic Cells in Dogs With Duchenne Muscular Dystrophy. Mol Ther. [Epub ahead of print].

O'Brien, K.F., and Kunkel, L.M. (2001). Dystrophin and muscular dystrophy: past, present, and future. Molecular Genetics and Metabolism 74, 75-88.

Partridge, T. (1991). Animal models of muscular dystrophy--what can they teach us? Neuropathol Appl. Neurobiol. 17, 353-363. 
Passos-Bueno, M.R., Vainzof, M., Marie, S.K., and Zatz, M. (1994). Half the dystrophin gene is apparently enough for a mild clinical course: confirmation of its potential use for gene therapy. Hum. Mol. Genet. 3, 919-922.

Passos-Bueno, M.R., Vainzof, M., Moreira, E.S., and Zatz, M. (1999). Seven autosomal recessive limb-girdle muscular dystrophies in the Brazilian population: from LGMD2A to LGMD2G. American Journal of Medical Genetics 82, 392-398.

Peault, B. et al. (2007). Stem and progenitor cells in skeletal muscle development, maintenance, and therapy. Molecular Therapy 15, 867-877.

Pelosi, L., Giacinti, C., Nardis, C., Borsellino, G., Rizzuto, E., Nicoletti, C., Wannenes, F., Battistini, L., Rosenthal, N., Molinaro, M., et al. (2007). Local expression of IGF-1 accelerates muscle regeneration by rapidly modulating inflammatory cytokines and chemokines. FASEB J. 21, 1393-1402.

Petrof, B.J., Shrager, J.B., Stedman, H.H., Kelly, A.M. and Sweeney, H.L. (1993). Dystrophin protects the sarcolemma from stresses developed during muscle contraction. Proc Natl Acad Sci U S A 90, 3710-3714.

Rando, T.A. (2001). The dystrophin-glycoprotein complex, cellular signaling, and the regulation of cell survival in the muscular dystrophies. Muscle Nerve 24, 1575-1594.

Romanov, Y.A., Svintsitskaya, V.A., and Smirnov, V.N. (2003). Searching for alternative sources of postnatal human mesenchymal stem cells: candidate MSC-like cells from umbilical cord. Stem Cells 21, 105-110.

Rooney, J.E., J. V. Welser, et al. (2006). Severe muscular dystrophy in mice that lack dystrophin and alpha7 integrin. J. Cell Sci. 119, 2185-2195.

Sacco, A., Doyonnas, R., LaBarge, M.A., Hammer, M.M., Kraft, P., and Blau, H.M. (2005). IGF-I increases bone marrow contribution to adult skeletal muscle and enhances the fusion of myelomonocytic precursors. J. Cell Biol. 171, 483492.

Sakuma, K. et al. (2000). Postnatal profiles of myogenic regulatory factors and the receptors of TGF-beta 2, LIF and IGF-I in the gastrocnemius and rectus femoris muscles of dy mouse. Acta Neuropathol 99, 169-176.

Sampaolesi, M. et al. (2006). Mesoangioblast stem cells ameliorate muscle function in dystrophic dogs. Nature 444, 574-579.

Seo, B.M., Miura, M., Gronthos, S., Bartold, P.M., Batouli, S., Brahim, J., Young, M., Robey, P.G., Wang, C.Y., and Shi, S. (2004). Investigation of multipotent postnatal stem cells from human periodontal ligament. Lancet. 364, 149-155. 
Sharp, N.J. et al. (1992). An error in dystrophin mRNA processing in golden retriever muscular dystrophy, an animal homologue of Duchenne muscular dystrophy. Genomics 13, 115-121.

Sparks, S.E., and Escolar, D.M. (2011). Congenital muscular dystrophies. Handb. Clin. Neurol. 101, 47-79.

Squire, S., Raymackers, J.M., Vandebrouck, C., Potter, A., Tinsley, J., Fisher, R., Gillis, J.M., and Davies, K.E. (2002). Prevention of pathology in mdx mice by expression of utrophin: analysis using an inducible transgenic expression system. Hum. Mol. Genet. 11, 3333-3344.

Steffen, L.S. et al. (2007). Zebrafish orthologs of human muscular dystrophy genes. BMC Genomics 8, 79.

Sunada, Y., Bernier, S.M., Kozak, C.A., Yamada, Y., and Campbell, K.P. (1994). Deficiency of merosin in dystrophic dy mice and genetic linkage of laminin $M$ chain gene to dy locus. Journal of Biological Chemistry 269, 13729-13732.

Sunada, Y., Bernier, S.M., Utani, A., Yamada, Y., and Campbell, K.P.(1995). Identification of a novel mutant transcript of laminin alpha 2 chain gene responsible for muscular dystrophy and dysmyelination in dy2 $\mathrm{J}$ mice. Human Molecular Genetics 4, 1055-1061.

Takahashi, K., Tanabe, K., Ohnuki, M., Narita, M., Ichisaka, T., Tomoda, K., and Yamanaka, S. (2007). Induction of pluripotent stem cells from adult human fibroblasts by defined factors. Cell 131, 861-872.

Thomson, J. A. et al. (1998). Embryonic stem cell lines derived from human blastocysts. Science 5391, 1145-1147.

Tinsley, J., Deconinck, N., Fisher, R., Kahn, D., Phelps, S., Gillis, J.M., and Davies, K. (1998). Expression of full-length utrophin prevents muscular dystrophy in mdx mice. Nat. Med. 4, 1441-14444.

Tidball, J.G. (2005). Inflammatory processes in muscle injury and repair. Am. J. Physiol. Regul. Integr. Comp. Physiol. 288, 345-353.

Urbach, A., Bar-Nur, O., Daley, G.Q., and Benvenisty, N. (2010). Differential modeling of fragile $X$ syndrome by human embryonic stem cells and induced pluripotent stem cells. Cell Stem Cell. 6, 407-411.

Urish, K. et al. (2005). Initial failure in myoblast transplantation therapy has led the way toward the isolation of muscle stem cells: potential for tissue regeneration. Curr. Top. Dev. Biol. 68, 263-280. 
Vachon, P., H., F. Loechel, et al. (1996). Merosin and laminin in myogenesis; specific requirement for merosin in myotube stability and survival. J. Cell Biol. 134, 1483-1497.

Vainzof, M., and Zatz, M. (2003). Protein defects in neuromuscular diseases. Brazilian Journal of Medical and Biological Research 36, 543-555.

Vainzof, M., Passos-Bueno, M.R., Takata, R.I., Pavanello Rde, C., and Zatz, M. (1993a). Intrafamilial variability in dystrophin abundance correlated with difference in the severity of the phenotype. J. Neurol. Sci. 119, 38-42.

Vainzof, M., Takata, R.I., Passos-Bueno, M.R., Pavanello, R.C., and Zatz, M. (1993b). Is the maintainance of the C-terminus domain of dystrophin enough to ensure a milder Becker muscular dystrophy phenotype? Hum. Mol. Genet. 2, 39-42.

Vainzof, M., Ayub-Guerrieri, D., Onofre, P.C., Martins, P.C., Lopes, V.F., Zilberztajn, D., Maia, L.S., Sell, K., and Yamamoto, L.U. (2008). Animal models for genetic neuromuscular diseases. J. Mol. Neurosci. 34, 241-248.

Van Deutekom, J.C., and Van Ommen, G.J. (2003). Advances in Duchenne muscular dystrophy gene therapy. Nat. Rev. Genet. 4, 774-783.

Vieira, N. M. et al. (2008). Sjl dystrophic mice express a significant amount of human muscle proteins following systemic delivery of human adipose-derived stromal cells without immunosupression. Stem Cells 26, 2391-2398.

Vieira, N.M., Zucconi, E., Bueno, C.R. Jr., Secco, M., Suzuki, M.F., Bartolini, P., Vainzof, M., and Zatz, M. (2010) Human multipotent mesenchymal stromal cells from distinct sources show different in vivo potential to differentiate into muscle cells when injected in dystrophic mice. Stem Cell Rev. 6, 560-566.

Vieira, N. M., Valadares, M., Zucconi, E., Secco, M., Bueno, C.R. Jr., Brandalise, V., Assoni, A., Gomes, J., Landini, V., Andrade, T., et al. (2011). Human Adipose-Derived Mesenchymal Stromal cells injected systemically into GRMD dogs without immunosupression are able to reach the host muscle and express human dystrophin. Cell Transplant. [Epub ahead of print].

Wagner, J., Kean, T., Young, R., Dennis, J.E., and Caplan, A.I. (2009). Optimizing mesenchymal stem cell-based therapeutics. Curr. Opin. Biotechnol. 20, 531-536.

Wang, B. et al. (2000). Adeno-associated virus carrying human minidystrophin genes effectively ameliorates muscular dystrophin in mdx mouse model. Proc. Natl. Acad. Sci. USA 97, 13714-13719. 
Wells, K.E., Fletcher, S., Mann, C.J., Wilton, S.D., and Wells, D.J. (2003). Enhanced in vivo delivery of antisense oligonucleotides to restore dystrophin expression in adult mdx mouse muscle. FEBS Letters 552, 145-149.

Winand, N.J., Edwards, M., Pradhan, D., Berian, C.A., and Cooper, B.J. (1994). Deletion of the dystrophin muscle promoter in feline muscular dystrophy. Neuromuscul Disord 4, 433-445.

Wong, B.L., and Christopher, C. (2002). Corticosteroids in Duchenne muscular dystrophy: a reappraisal. J. Child Neurol. 17, 183-190.

Yablonka-Reuveni, Z., and Anderson, J.E. (2006). Satellite cells from dystrophic ( $\mathrm{mdx}$ ) mice display accelerated differentiation in primary cultures and in isolated myofibers. Dev. Dyn. 235, 203-212.

Yuasa, K. et al. (2007). Injection of a recombinant AAV serotype 2 into canine skeletal muscles evokes strong immune responses against transgene products. Gene. Ther. 17, 1240-1260.

Zammit, P.S., T. A. Partridge, et al. (2006). The skeletal muscle satellite cell: the stem cell that came in from the cold. J. Histochem Cytochem 54, 1177-1191.

Zatz, M., Vainzof, M., Passos-Bueno, M.R. (2000). Limb-girdle muscular dystrophy: one gene with different phenotypes, one phenotype with different genes. Curr. Opin. Neurol. 13, 511-517.

Zatz, M., De Paula, F., Starling, A., and Vainzof, M. (2003). The 10 autosomal recessive limb-girdle muscular dystrophies. Neuromuscul Disord 13, 532-544.

Zucconi, E., Vieira, N.M., Bueno, C.R. Jr., Secco, M., Jazedje, T., Costa Valadares, M., Fussae Suzuki, M., Bartolini, P., Vainzof, M., and Zatz, M. (2011). Preclinical studies with umbilical cord mesenchymal stromal cells in different animal models for muscular dystrophy. J. Biomed Biotechnol. 2011:715251.

Zuk, P.A. et al. (2001). Multilineage cells from human adipose tissue: implications for cell-based therapies. Tissue Engineering 7, 211-228. 


\section{Capítulo 2}

\section{ISOLAMENTO DE CÉLULAS-TRONCO MESENQUIMAIS DE AMOSTRAS DE CORDÃO UMBILICAL HUMANO}

Artigo publicado em 2008

Stem Cells 2008; 26:146-150

Multipotent stem cells from umbilical cord: cord is richer than blood!

Mariane Secco, Eder Zucconi, Natassia M. Vieira, Luciana L. Q. Fogaça, Antonia Cerqueira, Maria Denise Fernandes Carvalho,

Tatiana Jazedje, Oswaldo K. Okamoto, Alysson R. Muotri, Mayana Zatz.

Neuromuscular Disorders 2008; 18:17-18 (ANEXO 1)

Mesenchymal stem cells from umbilical cord: Do not discard the cord!

Mariane Secco, Eder Zucconi, Natassia M. Vieira, Luciana L. Q. Fogaça, Antonia Cerqueira, Maria Denise Fernandes Carvalho, Tatiana Jazedje, Oswaldo K. Okamoto, Alysson R. Muotri, Mayana Zatz. 


\section{ABSTRACT}

The identification of mesenchymal stem cell (MSC) sources that are easily obtainable is of utmost importance. Several studies have shown that MSCs could be isolated from umbilical cord (UC) units. However, the presence of MSCs in umbilical cord blood (UCB) is controversial. A possible explanation for the low efficiency of MSCs from UCB is the use of different culture conditions by independent studies. Here, we compared the efficiency in obtaining MSCs from unrelated paired UCB and UC samples harvested from the same donors. Samples were processed simultaneously, under the same culture conditions. Although MSCs from blood were obtained from only 1 of the 10 samples, we were able to isolate large amounts of multipotent MSCs from all UC samples, which were able to originate different cell lineages. Since the routine procedure in UC banks has been to store the blood and discard other tissues, such as the cord and/or placenta, we believe our results are of immediate clinical value. Furthermore, the possibility of originating different cell lines from the UC of neonates born with genetic defects may provide new cellular research models for understanding human malformations and genetic disorders, as well as the possibility of testing the effects of different therapeutic drugs. 


\section{RESUMO}

A identificação de fontes de células-tronco mesenquimais (MSCs; do inglês Mesenchymal Stem Cells) de fácil obtenção é de extrema importância. Diversos estudos têm apontado que MSCs podem ser isoladas a partir do tecido do cordão umbilical. No entanto, a presença de MSCs no sangue de cordão umbilical é controversa. Uma possível explicação para a baixa eficiência no isolamento de MSCs do sangue do cordão é o uso de diferentes condições de cultura em estudos independentes. Portanto, neste estudo, comparamos a eficiência de isolamento de MSCs em amostras pareadas do sangue e do tecido do cordão umbilical humano, obtidas do mesmo doador, processadas simultaneamente e sob as mesmas condições de cultivo. Embora a eficiência de isolamento das MSCs do sangue foi de apenas uma entre 10 amostras avaliadas, fomos capazes de isolar grandes quantidades de MSCs multipotentes de todas as amostras do tecido do cordão umbilical, as quais foram capazes de originar diferentes linhagens celulares. Uma vez que o procedimento de rotina nos bancos de cordão umbilical é armazenar os sangue e descartar outros tecidos como o cordão umbilical e a placenta, acreditamos que nossos resultados são de valor clínico imediato. Além disso, a possibilidade de originar diferentes linhagens a partir do tecido do cordão umbilical de neonatos com defeitos genéticos pode proporcionar novos modelos de pesquisa para entender malformações humanas e doenças genéticas, bem como proporcionar a possibilidade de testar o efeito de diferentes drogas terapêuticas. 


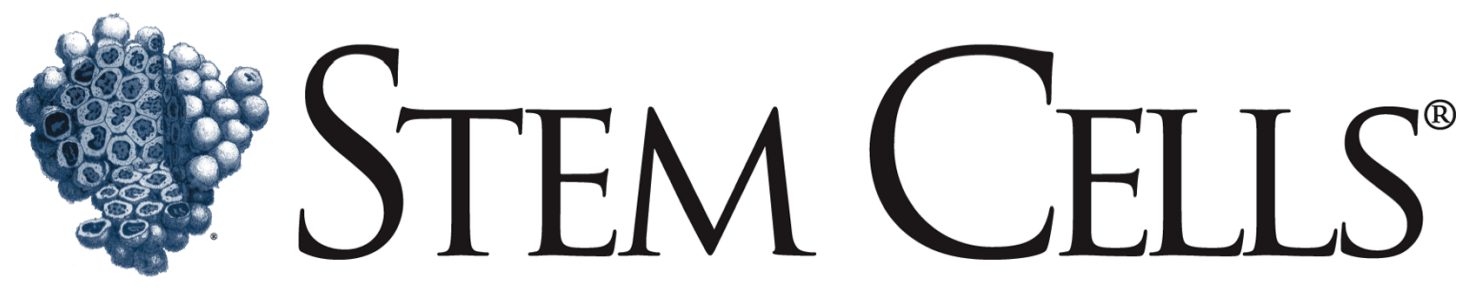

Multipotent Stem Cells from Umbilical Cord: Cord Is Richer than Blood! Mariane Secco, Eder Zucconi, Natassia M. Vieira, Luciana L.Q. Fogaça, Antonia Cerqueira, Maria Denise F. Carvalho, Tatiana Jazedje, Oswaldo K. Okamoto, Alysson R. Muotri and Mayana Zatz

Stem Cells 2008;26;146-150; originally published online Oct 11, 2007;

DOI: $10.1634 /$ stemcells.2007-0381

\section{This information is current as of January 21, 2008}

The online version of this article, along with updated information and services, is located on the World Wide Web at:

http://www.StemCells.com/cgi/content/full/26/1/146

STEM CELLS $®$, an international peer-reviewed journal, covers all aspects of stem cell research: embryonic stem cells; tissue-specific stem cells; cancer stem cells; the stem cell niche; stem cell genetics and genomics; translational and clinical research; technology development.

STEM CELLS $®$ is a monthly publication, it has been published continuously since 1983 . The Journal is owned, published, and trademarked by AlphaMed Press, 318 Blackwell Street, Suite 260, Durham, North Carolina, 27701. (C) 2008 by AlphaMed Press, all rights reserved. Print ISSN: 1066-5099. Online ISSN: 1549-4918.
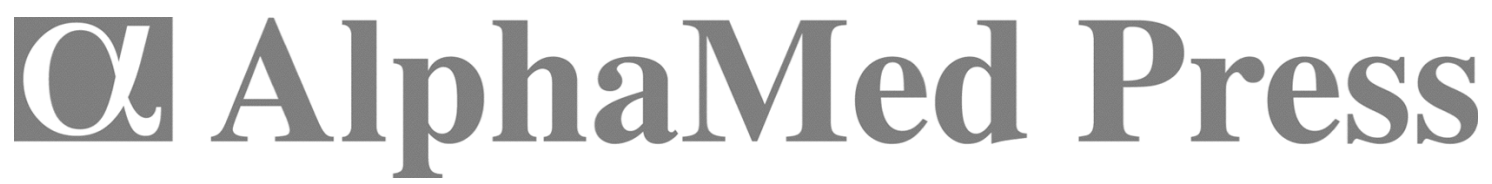


\title{
Stem Ceus
}

\section{The Stem Cell Niche}

\section{Multipotent Stem Cells from Umbilical Cord: Cord Is Richer than Blood!}

\author{
Mariane Secco, ${ }^{a}$ Eder Zucconi, ${ }^{a}$ Natassia M. Vieira, ${ }^{a}$ Luciana L.Q. FogaÇa,, antonia Cerqueira, \\ Maria Denise F. Carvalho, ${ }^{a}$ Tatiana Jazedje, ${ }^{a}$ Oswaldo K. OKamoto, ${ }^{b}$ Alysson R. Muotri, \\ MAYANA ZATZ \\ ${ }^{a}$ Human Genome Research Center, Department of Genetic and Evolutive Biology, University of São Paulo, São \\ Paulo, Brazil; ' ${ }^{\mathrm{D}}$ epartment of Neurology and Neurosurgery, Federal University of São Paulo, São Paulo, Brazil; \\ ${ }^{\mathrm{c}}$ Laboratory of Genetics, Salk Institute for Biological Studies, La Jolla, California, USA
}

Key Words. Human umbilical cord • Human umbilical cord blood • Mesenchymal stem cells • Umbilical cord banks

\begin{abstract}
The identification of mesenchymal stem cell (MSC) sources that are easily obtainable is of utmost importance. Several studies have shown that MSCs could be isolated from umbilical cord (UC) units. However, the presence of MSCs in umbilical cord blood (UCB) is controversial. A possible explanation for the low efficiency of MSCs from UCB is the use of different culture conditions by independent studies. Here, we compared the efficiency in obtaining MSCs from unrelated paired UCB and UC samples harvested from the same donors. Samples were processed simultaneously, under the same culture conditions. Although MSCs from blood were obtained from only 1 of the 10

samples, we were able to isolate large amounts of multipotent MSCs from all UC samples, which were able to originate different cell lineages. Since the routine procedure in UC banks has been to store the blood and discard other tissues, such as the cord and/or placenta, we believe our results are of immediate clinical value. Furthermore, the possibility of originating different cell lines from the UC of neonates born with genetic defects may provide new cellular research models for understanding human malformations and genetic disorders, as well as the possibility of testing the effects of different therapeutic drugs. STEM CELLS 2008;26: $146-150$
\end{abstract}

Disclosure of potential conflicts of interest is found at the end of this article.

\section{INTRODUCTION}

Mesenchymal stem cells (MSCs) are undifferentiated cells that are able to self-renew and that have a high proliferative capacity. These cells comprise a rare population of multipotent precursors that are capable of supporting hematopoiesis. Moreover, several reports suggest that MSCs were able to differentiate into various cell types, including chondrocytes, osteocytes, adipocytes, myocytes, and neurons [1-4]. MSCs can be isolated from different tissues, such as bone marrow (BM), adipose tissue, dental pulp, placenta, and umbilical cord blood (UCB), and from a variety of fetal tissues, such as spleen, lung, pancreas, kidneys, and amniotic fluid during midgestation [5-10]. Phenotypic and genetic evidence suggests that MSCs are an immature cell type, being a potentially useful model for developmental biology studies in normal and disease background, in addition to their therapeutic potential.

$\mathrm{BM}$ has been considered as one of the main sources of MSCs for both experimental and clinical applications, and most of the knowledge concerning MSCs comes from BM studies. However, MSCs from BM decrease significantly with age [11, 12], and their isolation is invasive and can cause infection, bleeding, and chronic pain. In past decades, human UCB has been regarded as an alternative source to BM cell transplantation and therapy because of its hematopoietic and mesenchymal components. Human UCB is obtained after full-term delivery of the newborn from a sample that would inevitably be discarded. The process is noninvasive, painless, and without harm for the mother or the infant.
Hematopoietic stem cells (HSCs) from UCB have already been proven to be useful in treating various hematological disorders [1316]. However, the presence of MSCs in UCB is controversial. Some researchers succeeded in isolating these cells [8, 17-19], whereas others failed or obtained a low yield [20-22]. More recently, some groups have reported success in isolating and establishing MSCs cultures from umbilical cord (UC) vein and UC stroma, also called Wharton's jelly [3, 20, 23-25]. According to Tondreau et al., the discrepant results in isolating MSC from UCB might be explained by different methodologies used for obtaining and culture these cells [26]. To address this issue, we compared 10 samples of UCB and UC, obtained from the same donors, regarding the presence of MSCs, as well as the differentiation potential in culture. Our results show that UC are rich in MSCs that are able to differentiate into various cell lines in vitro, whereas MSCs from blood were obtained from only 1 of the 10 samples. Based on these findings, we strongly suggest storing UC, in addition to $\mathrm{UCB}$, for future therapeutic applications and scientific investigation purposes.

\section{MATERIAls AND Methods}

\section{Harvesting of UCB and UC}

Ten human UCB and UC matching units were collected after informed consent was obtained from the mother in accordance with the ethical committee of Institute of Bioscience of University of São Paulo and Jesus José e Maria Hospital. Informed consent was obtained from all subjects. All studies and laboratory procedures

Correspondence: Mayana Zatz, Ph.D., Human Genome Research Center, Department of Genetic and Evolutive Biology, University of São Paulo, Rua do Matão, n. 106, Cidade Universitária, São Paulo, SP, CEP 05508-090, Brazil. Telephone: 55-11-3091-7966; Fax: 55-11-30917966; e-mail: mayazatz@usp.br Received May 18, 2007; accepted for publication September 28, 2007; first published online in STEM CELLS EXPRESS October 11, 2007. CAlphaMed Press 1066-5099/2007/\$30.00/0 doi: 10.1634/stemcells.2007-0381 
were carried out in the Human Genome Research Center, São Paulo, Brazil.

From each sample, UCB was harvested and conserved with 100 mM EDTA anticoagulant at $22^{\circ} \mathrm{C}$. Sections of $8-10 \mathrm{~cm}$ of umbilical cords, routinely discarded, were internally washed with phosphatebuffered saline (PBS) containing $300 \mathrm{U} / \mathrm{ml}$ penicillin and $300 \mu \mathrm{g} / \mathrm{ml}$ streptomycin (Gibco, Grand Island, NY, http://www.invitrogen. com) and immediately immersed in Dulbecco's modified Eagle's medium-low glucose (DMEM-LG; Gibco) supplemented with 10\% fetal bovine serum (FBS; Gibco), $300 \mathrm{U} / \mathrm{ml}$ penicillin, and 300 $\mu \mathrm{g} / \mathrm{ml}$ streptomycin. All samples were processed within 12-15 hours after collection.

\section{Isolation and Culture of Adherent Cells from UCB}

After blood dilution of 3:1 with RPMI 1640 medium (Gibco), mononuclear cells (MNCs) were isolated by density gradient centrifugation at $400 \mathrm{~g}$ for 30 minutes at room temperature using FicollPaque Premium (GE Healthcare, Little Chalfont, U.K., http://www. gehealthcare.com). MNCs were washed twice with PBS and resuspended in proliferation medium consisting of DMEM-LG, $10 \%$ FBS, $100 \mathrm{U} / \mathrm{ml}$ penicillin, and $100 \mu \mathrm{g} / \mathrm{ml}$ streptomycin. Cells were plated at a density of $5 \times 10^{7}$ cells per $\mathrm{ml}$ in culture flasks $(25$ $\mathrm{cm}^{2}$ ) and maintained at $37^{\circ} \mathrm{C}$ in a humidified atmosphere containing $5 \% \mathrm{CO}_{2}$. After 24 hours of incubation, nonadherent cells were removed, and culture medium was replaced every 3 days. Adherent cells were cultured until they reached $80 \%-90 \%$ confluence.

\section{Isolation and Culture of Adherent Cells from UC}

UCs were filled with $0.1 \%$ collagenase (Sigma-Aldrich, St. Louis, http://www.sigmaaldrich.com) in PBS and incubated at $37^{\circ} \mathrm{C}$ for 20 minutes. Each UC was washed with proliferation medium, and the detached cells were harvested after gentle massage of the UC. Cells were centrifuged at $300 \mathrm{~g}$ for 10 minutes, resuspended in proliferation medium, and seeded in $25-\mathrm{cm}^{2}$ flasks at a density of $5 \times 10^{7}$ cells per $\mathrm{ml}$. After 24 hours of incubation, nonadherent cells were removed and cultivated as described above.

\section{Immunophenotyping}

To analyze cell-surface expression of typical protein markers, adherent cells were incubated with the following anti-human primary antibodies: CD29-PECy5, CD34-PerCP, CD31-phycoerythrin (PE), CD45-fluorescein isothiocyanate (FITC), CD90-R-PE, CD117-PE, human leukocyte antigen (HLA)-ABC-FITC, HLA-DR-R-PE (Becton, Dickinson and Company, Franklin Lakes, NJ, http://www.bd. com), and SH3 (kindly provided by Dr. Kerkis, Instituto Butantã, São Paulo). Unconjugated markers were reacted with anti-mouse PE secondary antibody (Guava Technologies, Hayward, CA, http:// www.guavatechnologies.com). A total of 10,000 labeled cells were analyzed using a Guava EasyCyte flow cytometer running Guava ExpressPlus software (Guava Technologies).

\section{Cell Differentiation Procedures}

To evaluate MSC properties, adherent cells (third passage, at $80 \%-90 \%$ confluence) were subjected to adipogenic, chondrogenic, myogenic, and osteogenic differentiation in vitro, according to established protocols [1,3]. Normal human dermal fibroblasts were used as a negative control in the differentiation studies.

\section{Adipogenic Differentiation}

Subconfluent cells were cultured in proliferation medium supplemented with $1 \mu \mathrm{M}$ dexamethasone (Sigma-Aldrich), $500 \mu \mathrm{M}$ 3-isobutyl-1-methylxanthine (Sigma-Aldrich), $60 \mu \mathrm{M}$ indomethacin (Sigma-Aldrich), and $5 \mu \mathrm{g} / \mathrm{ml}$ insulin (Sigma-Aldrich). Adipogenic differentiation was confirmed on day 21 by intracellular accumulation of lipid-rich vacuoles stainable with oil red O (SigmaAldrich). For the oil red O stain, cells were fixed with $4 \%$ paraformaldehyde for 30 minutes, washed, and stained with a working solution of $0.16 \%$ oil red $\mathrm{O}$ for 20 minutes.

\section{Chondrogenic Differentiation}

A pellet culture system was used for chondrogenesis. Cells $(2.5 \times$ $10^{5}$ ) were centrifuged in a $15-\mathrm{ml}$ polypropylene tube at $500 \mathrm{~g}$ for 5 minutes, and the pellet was resuspended in $10 \mathrm{ml}$ of basal medium consisting of DMEM-LG supplemented with $100 \mathrm{nM}$ dexamethasone, $50 \mu \mathrm{M}$ ascorbic acid-2 phosphate (Sigma-Aldrich), $1 \mathrm{mM}$ sodium pyruvate (Gibco), and 1\% ITS-Premix (Becton Dickinson). Without disturbing the pellet, cells were resuspended in $0.5 \mathrm{ml}$ of chondrogenic differentiation medium consisting of basal medium supplemented with $10 \mathrm{ng} / \mathrm{ml}$ transforming growth factor- $\beta 1$ (R\&D Systems Inc., Minneapolis, http://www.rndsystems.com). On day 1, tubes were flipped gently to acquire a single floating cell sphere. Medium was changed every 3-4 days, and cells were fixed on day 21 with $4 \%$ paraformaldehyde. Cryosections $(10 \mu \mathrm{m}$ thick) were stained with toluidine blue to demonstrate extracellular matrix mucopolysaccharides.

For chondrogenic differentiation in monolayer culture, adherent cells were cultured in chondrogenic differentiation medium for 21 days. Chondrogenesis was demonstrated by staining with toluidine blue.

\section{Osteogenic Differentiation}

To promote osteogenic differentiation, subconfluent cells were treated with proliferation medium supplemented with $50 \mu \mathrm{M}$ ascorbate- 2 phosphate, $10 \mathrm{mM} \beta$-glycerophosphate (Sigma-Aldrich) and $0.1 \mu \mathrm{M}$ dexamethasone for 21 days. Osteogenesis was demonstrated by accumulation of mineralized calcium phosphate assessed by von Kossa stain. Briefly, cells were stained with $1 \%$ silver nitrate (Sigma-Aldrich) for 45 minutes under ultraviolet light, followed by 3\% sodium thiosulfate (Sigma-Aldrich) for 5 minutes, and then counterstained with van Gieson stain.

\section{Myogenic Differentiation}

For myogenic differentiation, adherent cells from UC were cultured in proliferation medium supplemented with $0.1 \mu \mathrm{M}$ dexamethasone (Sigma-Aldrich), $50 \mu \mathrm{M}$ hydrocortisone (Sigma-Aldrich), and 5\% horse serum (Gibco) for 30 days. After that, cells were fixed with $4 \%$ paraformaldehyde and blocked with a blocking solution containing 10\% fetal bovine serum, 5\% bovine serum albumin, and $0.1 \%$ Triton X-100 in PBS for 1 hour. Primary antibody was added at a concentration of 1:100 for Myosin (M7523; Sigma-Aldrich) and 1:20 for dystrophin (VP-D508; Vector Laboratories) and incubated at room temperature for 2 hours. After several washes, cells were incubated with secondary antibodies against mouse IgG tagged to FITC (green) or rabbit IgG tagged to cyanine 3 (red) for 2 hours at room temperature. Immunostaining controls were done in the same conditions but lacked the primary antibody. Slides were counterstained with 4,6-diamidino-2-phenylindole and mounted in Vectashield (Vector Laboratories, Burlingame, CA, http://www. vectorlabs.com) solution. All images in the same set (samples and controls) were obtained using the same photographic parameters of exposition and speed. Images were captured using the Axiovision 3.0 image analysis system (Carl Zeiss, Jena, Germany, http://www. zeiss.com).

\section{RESULTS}

\section{Isolation and Culture of Adherent Cells from UCB and $\mathrm{UC}$}

After plating MNCs from UCB, different cell types were observed. Most of them displayed an oval morphology (Fig. 1A), with few or no cytoplasmatic extensions. Some cells had an MSC-like phenotype (Fig. 1B), but most of them did not spread, migrate, or proliferate after 14 days in culture. Although we could isolate and expand MSCs from only one of the UCB units (data not shown), all the samples of UC generated primary adherent cultures, with cells displaying an MSC-like phenotype. After 4 days in culture, these cells grew in colonies, reaching confluence after 10-14 days. Most of the cells were spindle- 


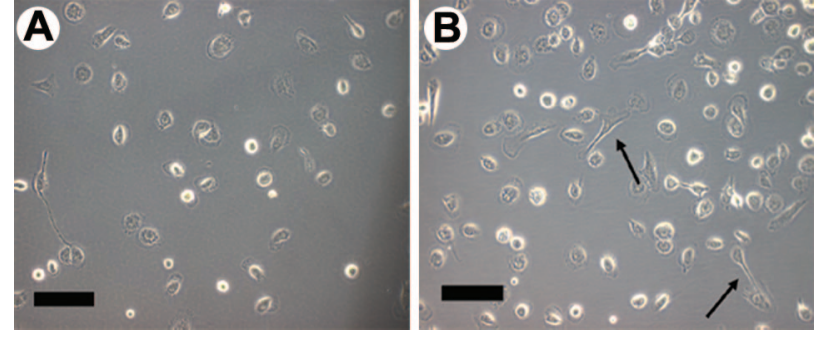

Figure 1. Morphology of adherent cells when isolated from umbilical cord blood. (A): Cells cultured for 4 days after initial plating displayed a round morphology. (B): Cells with an MSC-like phenotype (arrows) were also observed at day 4 but only in a few samples. However, these cells did not proliferate further than 14 days. Scale bars $=100 \mu \mathrm{m}$.

shaped, resembling fibroblasts. Some clusters of cells with endothelial appearance, which spread weakly and practically did not proliferate, could also be observed. After the second passage, adherent cells were constituted by homogeneous cell layers with an MSC-like phenotype (Fig. 2A-2D). The number of MSC from UC decreased slightly after freezing and thawing, and the remaining viable cells were successfully expanded on consecutive days (data not shown).

\section{Immunophenotypic Analyses}

All adherent cells derived from UC did not express hematopoietic lineage markers (CD34, CD45, and CD117) and endothelial markers (CD31), as assessed by flow cytometry. In addition, the majority of cells expressed high levels of adhesion markers (CD29 and CD90) and MSC markers (SH3). The isolated cells from UC were also positive for HLA-class I (HLA-ABC) but negative for HLA-class II (HLA-DR) (Fig. 3). In comparison with our fibroblast control, no obvious difference in the expression of these surface antigens could be observed (data not shown). Thus, the MSC property of isolated cells was further confirmed with cell differentiation studies.

\section{Multilineage Differentiation Potential}

The plasticity of adherent cells obtained from cord blood (CB) and UC was assessed 3 weeks after mesodermal induction. Osteogenic, adipogenic, and chondrogenic differentiation was demonstrated by the calcium deposits, lipid vacuoles, and mucopolysaccharide-rich extracellular matrix, respectively. No evident differences in MSCs from CB and UC differentiation potential were detected. Furthermore, an osteogenic, adipogenic, or chondrogenic phenotype was not observed in induced fibroblasts (negative controls; Fig. 4).

In addition, the potential of adherent cells from UC to differentiate into skeletal muscle cells was investigated. The myogenic differentiation was demonstrated by the expression of myogenic markers (myosin and dystrophin). As shown in Figure 5 , myosin and dystrophin were specifically expressed in the differentiated cells rather than in untreated cells (noninduced controls). Together, these results confirmed the mesenchymal nature of the isolated cells and their multipotency.

\section{DISCUSSION}

In this study we compared, for the first time, the efficiency in obtaining MSCs from match-paired UCB and UC samples harvested from the same donors, which were processed simultaneously and under the same culture conditions. Although MSCs from blood were obtained from only 1 of the 10 samples, we were able to generate primary MSCs cultures from all cord
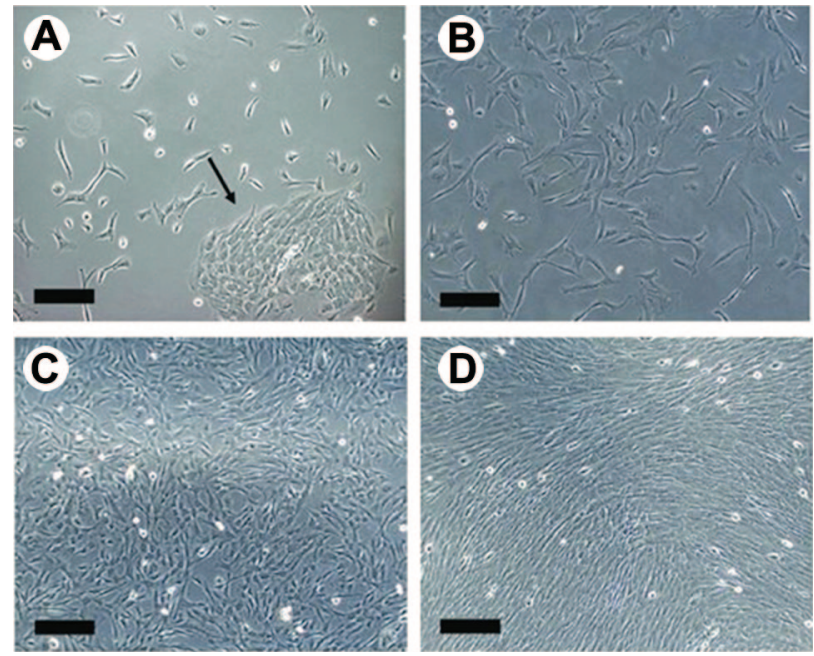

Figure 2. Adherent cells in primary cultures of UC. (A-D): The morphology and growth of cells with an MSC-like phenotype after 4, 7, 10, and 14 days of culturing, respectively. Some residual clusters of cells with endothelial appearance (arrow) could also be identified. Scale bars $=200 \mu \mathrm{m}$

samples with a $100 \%$ yield. MSCs from UC are isolated by a fast and simple procedure using short enzymatic digestion (which provides a large number of cells without risk to the donor) and can easily be expanded in vitro, stored cryogenically, and thawed. MSCs have been reported to be isolated from UC by others, using different protocols [3, 23, 24, 27-30]. Likewise, difficulties in obtaining MSCs from UCB have been reported previously $[8,17]$. Based on our experience, the efficiency in isolating MSC from blood in approximately 100 umbilical cord units stands around 10\% (unpublished data).

Crucial parameters for the isolation of MSCs from UCB, such as time between collection and processing, the volume of samples, and the amount of MNC have been already described. Even so, the MSCs yield is never greater than 60\% [19]. Recently, MSCs have successfully been derived from CD133+ hematopoietic stem cells originated from UCB [26]. However, this method would not allow the simultaneous isolation of hematopoietic and mesenchymal progenitors.

In mobilized peripheral blood, controversial results have been reported about the presence or absence of MSCs [22, 31-33]. da Silva Meirelles et al. reported that MSCs could not be detected in circulating blood in adult rats and suggested that all tissues have MSCs reservoirs localized in the perivascular niche [33]. According to these authors, it might be possible that during harvesting procedures only a few cells would detach from this perivascular niche as a result of needle syringe friction in blood vessel wall or the pressure applied in the UC during blood collection. On the other hand, a full success in obtaining MSCs from UC by our group and others might be explained by enzymatic dissociation processes within the UC perivascular niche. It is questionable whether the results observed in rats can be extrapolated to human samples and whether both MSC populations described here share the same genetic repertoire.

It has been suggested that the removal of myeloid and osteoclast-like cells seems to favors the isolation of MSCs from UCB [19]. Therefore, cocultivation with other hematopoietic cell types could inhibit the proliferation of the few MSCs present in the sample. Although some adherent primary cultures of UC contained cells with an endothelial phenotype, in our conditions, such contaminants did not interfere with MSCs growth. Others have also suggested that MSCs occurred at a low 

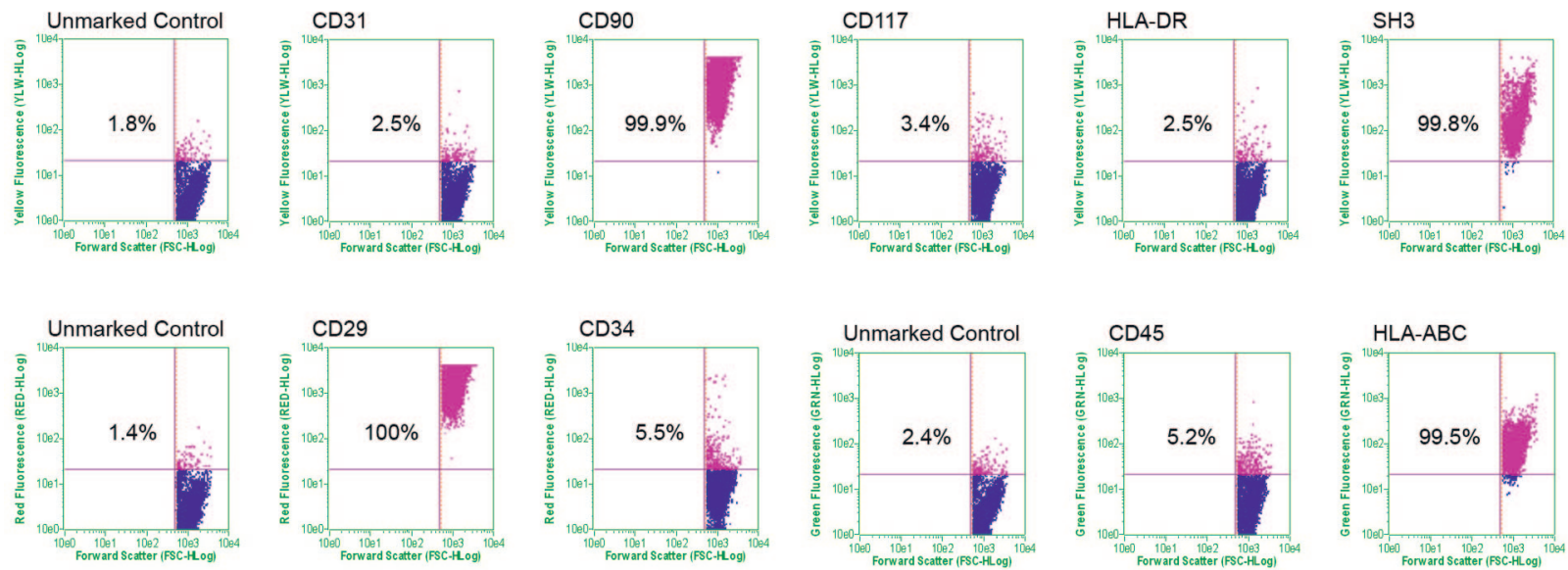

Figure 3. Immunophenotyping of adherent cells isolated from umbilical cord. Values represent the mean percentage of all assessed cells positively stained by the indicated antigens and analyzed by flow cytometry. Graphs show forward scatter versus fluorescence intensity. Abbreviations: HLA-ABC, human leukocyte antigen-ABC; HLA-DR, human leukocyte antigen-DR; SH3, Src homology 3.
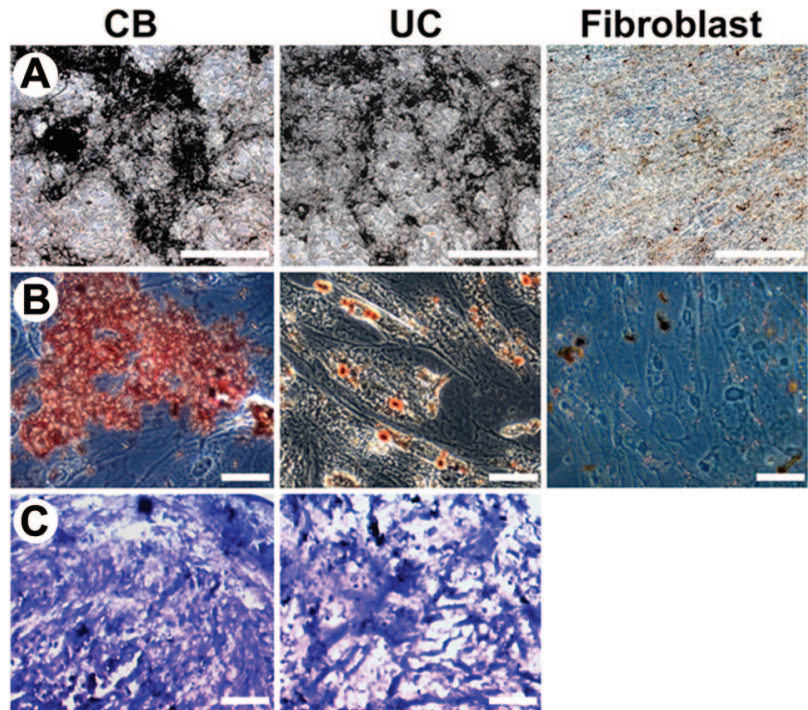

D

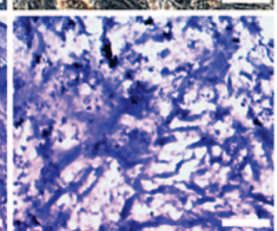

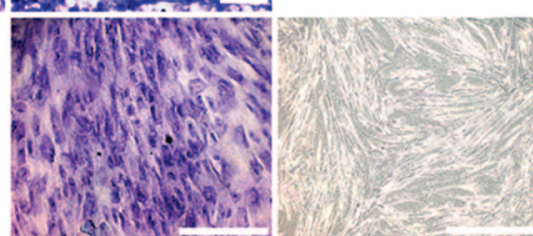

Figure 4. Differentiation potential of adherent cells isolated from $\mathrm{CB}$ and UC. (A): Osteogenic differentiation from adherent cells from CB and UC was demonstrated by calcium deposition shown by von Kossa stain. Scale bar $=50 \mu \mathrm{m}$. (B): Adipogenesis was detected by the formation of intracytoplasmic lipid droplets stained with oil red O. Scale bar $=200 \mu \mathrm{m}$. (C): Cell spheres from CB and UC were stained with toluidine blue to confirm chondrogenic differentiation. Mucopolysaccharide-rich extracellular matrix is shown in pinkish metachromatic areas. (D): Chondrogenic differentiation in monolayer culture of MSC from UC was demonstrated by stained with toluidine blue. Scale bars $=50 \mu \mathrm{m}$. (A, B, D): Osteogenic, adipogenic, or chondrogenic phenotype was not observed in induced fibroblasts (negative controls). Scale bars $=200 \mu \mathrm{m}$. More details are given in Materials and Methods. Abbreviations: CB, cord blood; UC, umbilical cord.

frequency in UCB and that their survival could be affected by different culture conditions [26]. However, our results show that the low yield of MSCs in UCB is likely not due to different culture methodologies.

www.StemCells.com
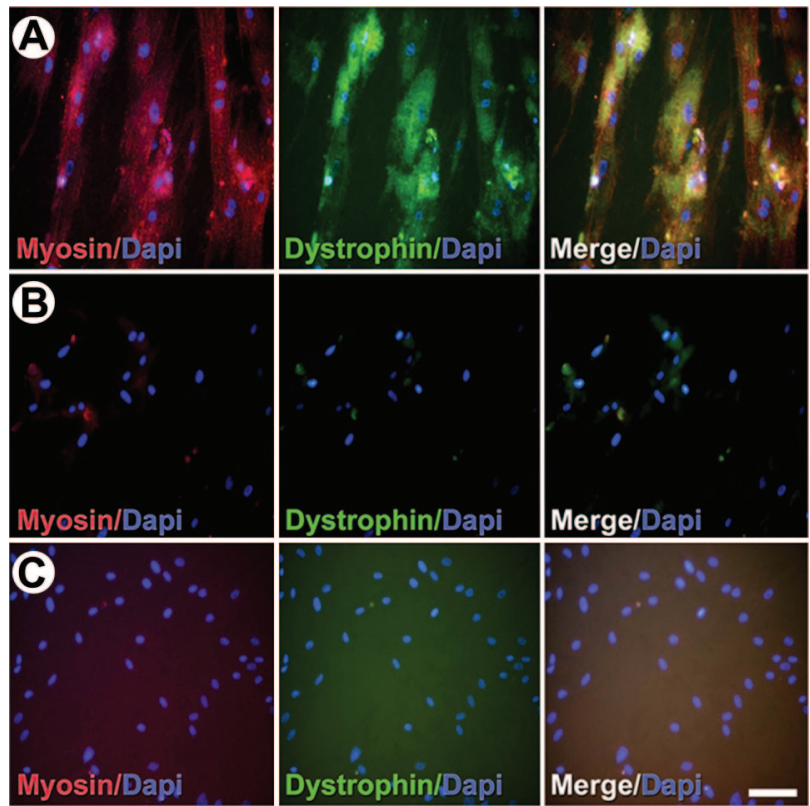

Figure 5. Myogenic differentiation potential of adherent cells isolated from umbilical cord. (A): Myogenic differentiation was assessed by immunocytochemistry. Induced cells were strongly labeled with antihuman myosin monoclonal antibody (Sigma-Aldrich) in red and, with anti-human dystrophin (dys1) monoclonal antibody (Vector Laboratories) in green. Counterstaining with Dapi (in blue) was used to identify all nuclei. (B): Noninduced controls. (C): Negative controls (without the first antibody). Scale bar $=50 \mu \mathrm{m}$. Abbreviation: Dapi, 4,6-diamidino-2-phenylindole.

An important issue in cellular therapy studies is the availability of alternative stem cell sources and the efficacy of isolation techniques to yield a reasonable amount of viable cells that could be successfully expanded. Despite the advantages of HSC from UCB in hematopoietic reconstitution [13-15], results from the present study demonstrated that UC, and not $\mathrm{UCB}$, is the best choice for isolating MSCs for future applications. Until very recently, BM has been considered the main source of MSCs. Panepucci et al. demonstrated that MSCs derived from UC and BM are highly similar at the transcriptional level, reinforcing the usefulness of UC from neonates [34]. 
In short, based on the present results and other studies, we believe that UC is the easiest obtainable biological source of MSCs. Storing UCB in private or public banks has been recently the subject of many ethical dilemmas. Here we show that regardless of being public or private, these banks are discarding a precious source of MSCs. In addition, since human UC contain a significant amount of MSCs, we suggest donors to split samples, storing in both public and private banks. Storing both UCB and UC would allow maximum recovery of HSCs and MSCs for possible therapeutic applications in the future. Furthermore, the possibility of originating different UC-derived cell lines from babies born with human malformations and genetic disorders may provide new research models for understanding pathological mechanisms responsible for these conditions. In addition, storing both UCB and UC would also create the possibility of testing the effects of therapeutic drugs in these different cell lineages.

\section{ACKNOWLEDGMENTS}

The collaboration of the following people is gratefully acknowledged: Constancia Urbani, Dr. Mariz Vainzof, Dr. Maria Rita Passos Bueno, Daniela Franco Bueno, the group of Dr. Irina Kerkis, and members of the Jesus José e Maria Hospital staff, particularly Roseli Aparecida Bueno and Solange Cabral da Silva. This work was supported by grants from Centro de Pesquisa, Inovação e Difusão-Fundação de Amparo a Pesquisa do Estado de São Paulo and Conselho Nacional de Desenvolvimento Científico e Tecnológico. M.S. and E.Z. contributed equally to this work.

\section{Disclosure of Potential Conflicts OF INTEREST}

The authors indicate no potential conflicts of interest.

\section{REFERENCES}

1 Zuk PA, Zhu M, Ashjian P et al. Human adipose tissue is a source of multipotent stem cells. Mol Biol Cell 2002;13:4279-4295.

2 Gang EJ, Jeong JA, Hong SH et al. Skeletal myogenic differentiation of mesenchymal stem cells isolated from human umbilical cord blood. STEM CELLS 2004;22:617-624.

3 Karahuseyinoglu S, Cinar O, Kilic E et al. Biology of the stem cells in human umbilical cord stroma: In situ and in vitro surveys. STEM CELLS 2007;25:319-331.

4 Kern S, Eichler H, Stoeve J et al. Comparative analysis of mesenchymal stem cells from bone marrow, umbilical cord blood, or adipose tissue. STEM CELLS 2006;24:1294-1301.

5 Zuk PA, Zhu M, Mizuno $\mathrm{H}$ et al. Multilineage cells from human adipose tissue: Implication for cell-based therapies. Tissue Eng 2001;7:211-228.

6 Gronthos S, Brahim J, Li W et al. Stem cell properties of human dental pulp stem cells. J Dent Res 2002;81:531-535.

7 Jiang Y, Jahagirdar BN, Reinhardt RL et al. Pluripotency of mesenchymal stem cells derived from adult marrow. Nature 2002;418:41-49.

8 Lee OK, Kuo TK, Chen WM et al. Isolation of multipotent mesenchymal stem cells from umbilical cord blood. Blood 2004;103:1669-1675.

9 Yen BL, Huang HI, Chien CC et al. Isolation of multipotent cells from human term placenta. STEM CELLS 2005;23:3-9.

10 De Coppi PD, Bartsch G, Siddigui MM et al. Isolation of amniotic stem cell lines with potential for therapy. Nat Biotechnol 2007;25:100-106.

11 Mueller SM, Glowacki J. Age-related decline in the osteogenic potential of human bone marrow cells cultured in three-dimensional collagen sponges. J Cell Biochem 2001;82:583-590.

12 Stenderup K, Justuesen J, Clausen $\mathrm{C}$ et al. Aging is associated with decreased maximal life span and accelerated senescence of bone marrow stromal cells. Bone 2003;33:919-926.

13 Cohena Y, Nagler A. Hematopoietic stem-cell transplantation using umbilical-cord blood. Leuk Lymphoma 2003;44:1287-1299.

14 Ooi J. The efficacy of unrelated cord blood transplantation for adult myelodysplastic syndrome. Leuk Lymphoma 2006;47:599-602.

15 Laughlin MJ, Barker J, Bamback B et al. Hematopoietic engraftment and survival in adult recipients of umbilical-cord blood from unrelated donors. N Engl J Med 2001;344:1815-1822.

16 Hayani A, Lampeter E, Viswanatha D et al. First report of autologous cord blood transplantation in the treatment of a child with leukemia. Pediatrics 2007;119:e296-e300.

17 Erices A, Conget P, Minguell JJ. Mesenchymal progenitor cells in human umbilical cord blood. Br J Haematol 2000;109:235-242.

18 Goodwin HS, Bicknese AR, Chien SN et al. Multilineage differentiation activity by cells isolated from umbilical cord blood: Expression of bone, fat and neural markers. Biol Blood Marrow Transplant 2001;7:581-588.

19 Bieback K, Kern S, Kluter $\mathrm{H}$ et al. Critical parameters for the isolation of mesenchymal stem cells from umbilical cord blood. STEM CELLS 2004;22:625-634

20 Romanov YA, Svintsitskaya VA, Smirnov VN. Searching for alternative sources of postnatal human mesenchymal stem cells: Candidate MSClike cells from umbilical cord. STEM CELLS 2003;21:105-110.

21 Mareschi K, Biasin E, Piacibello W et al. Isolation of human mesenchymal stem cells: Bone marrow versus umbilical cord blood. Haematologica 2001;86:1099-1100.

22 Wexler SA, Donaldson C, Denning-Kendall P et al. Adult bone marrow is a rich source of human mesenchymal 'stem' cells but umbilical cord and mobilized adult blood are not. Br J Haematol 2003;121:368-374.

23 Wang HS, Hung SC, Peng ST et al. Mesenchymal stem cells in the Wharton's jelly of the human umbilical cord. STEM CELLS 2004;22: $1330-1337$

24 Sarugaser R, Lickorish D, Baksh D et al. Human umbilical cord perivascular (HUCPV) cells: A source of mesenchymal progenitors. STEM CELLS 2005;23:220-229.

25 Can A, Karahuseyinoglu, S. Concise review: Human umbilical cord stroma with regard to the source of fetus-derived stem cells. STEM CELLS 2007 [Epub ahead of print]

26 Tondreau T, Meuleman N, Delforge A et al. Mesenchymal stem cells derived from CD133-positive cells in mobilized peripheral blood and cord blood: Proliferation, Oct4 expression, and plasticity. STEM CELLS 2005;23:1105-1112.

$27 \mathrm{Fu}$ YS, Cheng YC, Lin MY et al. Conversion of human umbilical cord mesenchymal stem cells in Wharton's jelly to dopaminergic neurons in vitro: Potential therapeutic application for Parkinsonism. STEM CELLS 2006; $24: 115-124$

28 Conconi MT, Burra P, Di Liddo R et al. CD105(+) cells from Wharton's jelly show in vitro and in vivo myogenic differentiative potential. Int J Mol Med 2006;18:1089-1096.

29 Mitchell KE, Weiss ML, Mitchell BM et al. Matrix cells from Wharton's jelly form neurons and glia. STEM CELLS 2003;21:50-60.

30 Weiss ML, Medicetty S, Bledsoe AR et al. Human umbilical cord matrix stem cells: Preliminary characterization and effect of transplantation in a rodent model of Parkinson's disease. STEM CELLS 2006;24:781-792.

31 Fernandez M, Simon V, Herrera G et al. Detection of stromal cells in peripheral blood progenitor cell collections from breast cancer patients. Bone Marrow Transplant 1997;20:265-271.

32 Zvaifler NJ, Marinova-Mutafchieva L, Adams G et al. Mesenchymal precursor cells in the blood of normal individuals. Arthritis Res 2000;2: $477-488$.

33 da Silva Meirelles L, Chagastelles PC, Nardi NB. Mesenchymal stem cells reside in virtually all post-natal organs and tissues. J Cell Sci 2006;119:2204-2213.

34 Panepucci RA, Siufi JL, Silva WA et al. Comparison of gene expression of umbilical cord vein and bone marrow-derived mesenchymal stem cells. STEM CELLS 2004;22:1263-1278. 
Multipotent Stem Cells from Umbilical Cord: Cord Is Richer than Blood!

Mariane Secco, Eder Zucconi, Natassia M. Vieira, Luciana L.Q. Fogaça, Antonia

Cerqueira, Maria Denise F. Carvalho, Tatiana Jazedje, Oswaldo K. Okamoto, Alysson

R. Muotri and Mayana Zatz

Stem Cells 2008;26;146-150; originally published online Oct 11, 2007;

DOI: $10.1634 /$ stemcells.2007-0381

This information is current as of January 21, 2008 


\section{Capítulo 3}

\section{ANÁLISE COMPARATIVA DO PERFIL DE EXPRESSÃO GÊNICA DE CÉLULAS-TRONCO MESENQUIMAIS HUMANAS PROVENIENTES DE AMOSTRAS DE SANGUE DE CORDÃO VERSUS TECIDO DE CORDÃO UMBILICAL}

Artigo Publicado em 2009

Stem Cells Rev 2009; 5(4):387-401

Gene expression profile of mesenchymal stem cells from paired umbilical cord units: cord is different from blood.

Mariane Secco, Yuri B. Moreira, Eder Zucconi, Natassia M. Vieira, Tatiana Jazedje, Alysson R. Muotri, Oswaldo K. Okamoto, Sergio Verjovski-Almeida, Mayana Zatz 


\section{ABSTRACT}

Mesenchymal stem cells (MSC) are multipotent cells which can be obtained from several adult and fetal tissues including human umbilical cord units. We have recently shown that umbilical cord tissue (UC) is richer in MSC than umbilical cord blood (UCB) but their origin and characteristics in blood as compared to the cord remains unknown. Here we compared, for the first time, the exonic protein-coding and intronic noncoding RNA (ncRNA) expression profiles of MSC from match-paired UC and UCB samples, harvested from the same donors, processed simultaneously and under the same culture conditions. The patterns of intronic ncRNA expression in MSC from UC and UCB paired units were highly similar, indicative of their common donor origin. The respective exonic protein-coding transcript expression profiles, however, were significantly different. Hierarchical clustering based on protein-coding expression similarities grouped MSC according to their tissue location rather than original donor. Genes related to systems development, osteogenesis and immune system were expressed at higher levels in UCB, whereas genes related to cell adhesion, morphogenesis, secretion, angiogenesis and neurogenesis were more expressed in UC cells. These molecular differences verified in tissue-specific MSC gene expression may reflect functional activities influenced by distinct niches and should be considered when developing clinical protocols involving MSC from different sources. In addition, these findings reinforce our previous suggestion on the importance of banking the whole umbilical cord unit for research or future therapeutic use. 


\section{RESUMO}

Células-tronco mesenquimais (MSCs; do inglês Mesenchymal Stem Cells) são células multipotentes que podem ser obtidas de diversos tecidos fetais e adultos, incluindo amostras de cordão umbilical humano. Recentemente, nós demonstramos que o tecido do cordão umbilical é mais rico em MSCs do que o sangue do cordão umbilical. Aqui, nós comparamos, pela primeira vez, o perfil de expressão intrônico e exônico de MSCs provenientes de amostras de sangue de cordão e tecido de cordão umbilical humano pareadas, ou seja, obtidas do mesmo doador, processadas simultaneamente e cultivadas nas mesmas condições. O padrão de expressão intrônico foi bastante similar entre as amostras pareadas de MSCs de sangue de cordão e tecido de cordão umbilical, o que indica a origem comum do doador. Entretanto, seu respectivo padrão de expressão exônica foi significativamente diferente. Os agrupamentos hierárquicos baseados nas similaridades de expressão exônicas separaram as MSCs de acordo com o seu tecido de origem e não de acordo com o indivíduo doador. Genes relacionados com desenvolvimento, osteogênese e sistema imune foram altamente expressos nas MSCs de sangue de cordão umbilical, enquanto que genes relacionados com adesão celular, morfogênese, secreção, angiogênese e neurogênese foram mais expressos nas amostras provenientes de tecido de cordão umbilical humano. Essas diferenças moleculares no perfil de expressão gênica de células-tronco tecido-específicas podem refletir a funcionalidade da célula influenciada pelo seu nicho e deve ser considerada em protocolos clínicos envolvendo células-tronco de diferentes origens. Além disso, esses achados reforçam nossa sugestão anterior de armazenar amostras de tecido de cordão umbilical para pesquisa e aplicações terapêuticas futuras. 


\title{
Gene Expression Profile of Mesenchymal Stem Cells from Paired Umbilical Cord Units: Cord is Different from Blood
}

\author{
Mariane Secco • Yuri B. Moreira • Eder Zucconi • Natassia M. Vieira • \\ Tatiana Jazedje • Alysson R. Muotri • Oswaldo K. Okamoto • \\ Sergio Verjovski-Almeida • Mayana Zatz
}

(C) The Author(s) 2009. This article is published with open access at Springerlink.com

\begin{abstract}
Mesenchymal stem cells (MSC) are multipotent cells which can be obtained from several adult and fetal tissues including human umbilical cord units. We have recently shown that umbilical cord tissue (UC) is richer in MSC than umbilical cord blood (UCB) but their origin and characteristics in blood as compared to the cord remains unknown. Here we compared, for the first time, the exonic protein-coding and intronic noncoding RNA (ncRNA) expression profiles of MSC from match-paired UC and UCB samples, harvested from the same donors, processed simultaneously and under the same culture conditions. The patterns of intronic ncRNA expression in MSC from UC
\end{abstract}

Mariane Secco and Yuri B. Moreira contributed equally to this work.

Electronic supplementary material The online version of this article (doi:10.1007/s12015-009-9098-5) contains supplementary material, which is available to authorized users.

M. Secco • E. Zucconi $\cdot$ N. M. Vieira $\cdot$ T. Jazedje $\cdot$ M. Zatz $(\bowtie)$ Human Genome Research Center, Department of Genetic and Evolutive Biology, University of São Paulo,

Rua do Matão, 106 - Cidade Universitária, 05508-090 São Paulo, SP, Brazil

e-mail: mayazatz@usp.br

Y. B. Moreira $\cdot$ S. Verjovski-Almeida

Departamento de Bioquimica, Instituto de Quimica,

Universidade de São Paulo,

05508-900 São Paulo, SP, Brazil

A. R. Muotri

UCSD Stem Cell Initiative, Department of Pediatrics and Cellular \& Molecular Biology, University of California San Diego,

La Jolla, CA 92093-0695, USA

\section{O. K. Okamoto}

Department of Neurology and Neurosurgery,

Federal University of São Paulo,

04023-900 São Paulo, SP, Brazil and UCB paired units were highly similar, indicative of their common donor origin. The respective exonic protein-coding transcript expression profiles, however, were significantly different. Hierarchical clustering based on protein-coding expression similarities grouped MSC according to their tissue location rather than original donor. Genes related to systems development, osteogenesis and immune system were expressed at higher levels in UCB, whereas genes related to cell adhesion, morphogenesis, secretion, angiogenesis and neurogenesis were more expressed in UC cells. These molecular differences verified in tissue-specific MSC gene expression may reflect functional activities influenced by distinct niches and should be considered when developing clinical protocols involving MSC from different sources. In addition, these findings reinforce our previous suggestion on the importance of banking the whole umbilical cord unit for research or future therapeutic use.

Keywords Human umbilical cord · Human umbilical cord blood - Mesenchymal stem cells $\cdot$ Comparative gene expression profile

\begin{tabular}{ll}
\multicolumn{2}{l}{ Abbreviations } \\
MSC & Mesenchymal stem cells \\
HSC & Hematopoietic stem cells \\
UC & Umbilical cord \\
UCB & Umbilical cord blood \\
BM & Bone marrow
\end{tabular}

\section{Introduction}

Multipotent mesenchymal stem cells (MSC) are an immature cell type with ability to self-renew and differentiate 
into specific functional cell types including chondrocytes, osteocytes, adipocytes, myocytes, and neurons. Phenotypic and genetic lines of evidence suggest that MSC are a useful model for developmental biology studies in normal and disease backgrounds, in addition to their therapeutic potential [1-4].

MSC were originally isolated from bone marrow (BM). Subsequently, similar populations have been reported in other tissues, such as adipose tissue [5, 6], dental pulp [7], placenta, umbilical cord blood (UCB) and umbilical cord tissue (UC), as well as from a variety of fetal tissues, such as spleen, lung, pancreas, kidney, and amniotic fluid during midgestation [8-13]. According to some authors, MSC are located in the vascular wall, constituting a MSC compartment extending throughout the entire organism [14-18]. In fact, it is known that many tissues contain lineage-committed progenitor cells for their maintenance and repair and several studies have demonstrated the presence of uncommitted MSC within the perivascular niche of several organs in animal models, where their function is to stabilize blood vessels, and to contribute to tissue homeostasis [19-21]. On the other hand, MSC seem to be absent from the circulating blood under normal physiological conditions [17, 22] and their presence in term UCB is controversial; some researchers successfully isolated MSC from UCB [10, 23-25], whereas others failed or obtained cells at low yield [11, 22, $26,27]$. We have recently shown that UC is much richer in MSC than UCB [11]. However, the question of whether the cells obtainable from both compartments were actually the same entity or not remained unanswered.

Several studies based on protein-coding gene expression profiling have been conducted with the aim of enhancing our understanding on MSC biology and ontogeny [28-33]. Further, recent investigation has demonstrated that noncoding RNAs, in addition to protein-coding genes, encompass several functions related to stem cell biology, including the maintenance of pluripotency and induction of cellular differentiation programs [34]. Given their presence in other cell-types and tissue, the noncoding transcripts are likely to be involved in other aspects of mammalian developmental and cellular biology [34-38]. More specifically, there are already a few examples of cellular mechanisms involving noncoding RNAs such as: an antisense noncoding RNA regulating usage of alternatively spliced isoforms of the Fas protein-coding gene transcribed from the same locus [39]; an antisense noncoding RNA regulating translation of the host PU.1 protein-coding gene [40]; and an intronic noncoding RNA from the CFTR locus regulating the expression of genes for specific cellular processes related to the function of the CFTR protein-coding gene [41].

Considering that large-scale expression studies are commonly restricted to protein-coding genes [28-33], studying the new and expanding class of noncoding RNA transcripts in a genome-wide scale is of great interest and may enhance our understanding of their biological functions in MSC.

Here, we analyzed, for the first time, the exonic proteincoding and intronic noncoding RNA expression profiles from match-paired UCB and UC samples, which were harvested from the same donors, processed simultaneously, and kept under the same culture conditions. The intronic noncoding RNA expression pattern of MSC from UC and UCB paired samples were highly similar suggesting that they share a common cellular origin. Surprisingly, we found significant differences in the global exonic protein-coding transcript expression patterns of MSC from UCB and UC paired samples, suggesting tissue specificity. These findings provide new insights on the biology and ontogeny of MSC in vivo, and add new information to be considered when developing clinical protocols involving MSC obtained from different sources.

\section{Materials and Methods}

\section{Harvesting of UC and UCB}

Sixty-five human UC and UCB matching units were collected after informed consent from all mothers and in accordance with the ethical committee of Jesus, José e Maria Hospital, University Hospital and Institute of Bioscience of University of São Paulo.

UCB was harvested from each sample, and conserved with $100 \mathrm{mM}$ EDTA anticoagulant at $22^{\circ} \mathrm{C}$. Sections of $8-10 \mathrm{~cm}$ of umbilical cords, which are routinely discarded, were internally washed with phosphate-buffered saline (PBS), supplemented with 3\% penicillin/streptomycin (Invitrogen-Gibco, Grand Island, NY, http://www.invitrogen.com) and immediately immersed in Dulbecco's modified Eagle's medium-low glucose (DMEM-LG; Invitrogen-Gibco) supplemented with $10 \%$ fetal bovine serum (FBS; Invitrogen-Gibco) and 3\% penicillin/streptomycin (Invitrogen-Gibco). All samples were processed within $12-15 \mathrm{~h}$ after collection.

Isolation and Culture of Adherent Cells from UCB and UC

After blood dilution of 3:1 with RPMI 1640 medium (Invitrogen-Gibco), mononuclear cells (MNCs) were isolated by density gradient centrifugation at $400 \mathrm{x} \mathrm{g}$ for $30 \mathrm{~min}$ at room temperature $\left(25^{\circ} \mathrm{C}\right)$ using Ficoll-Paque Premium (GE Healthcare, Little Chalfont, U.K., http://www.gehealthcare. com). MNCs were washed twice with PBS and resuspended in proliferation medium consisting of DMEM-LG, $10 \%$ FBS, $100 \mathrm{U} / \mathrm{ml}$ penicillin and $1 \%$ penicillin/streptomycin. Cells were plated at a density of $5 \times 10^{7}$ cells per $\mathrm{ml}$ in 
culture flasks $\left(25 \mathrm{~cm}^{2}\right)$ and maintained at $37^{\circ} \mathrm{C}$ in a humidified atmosphere containing $5 \% \mathrm{CO}_{2}$.

UCs were filled with $0.1 \%$ collagenase (Sigma-Aldrich, St. Louis, http://www.sigmaaldrich.com/sigma-aldrich/ home.html) in PBS and incubated at $37^{\circ} \mathrm{C}$ for $20 \mathrm{~min}$. Each UC was washed with proliferation medium, and the detached cells were harvested after gentle massage of the UC. Cells were centrifuged at $300 \mathrm{~g}$ for $10 \mathrm{~min}$, resuspended in proliferation medium, and seeded in $25-\mathrm{cm}^{2}$ flasks at a density of $5 \times 10^{7}$ cells per $\mathrm{ml}$.

After $24 \mathrm{~h}$ of incubation, non-adherent cells were removed, and culture medium was replaced every 3 days.

\section{Immunophenotyping}

To analyze cell-surface expression of typical protein markers, adherent cells were incubated with the following anti-human primary antibodies: CD29-PECy5, CD34-PerCP, CD31phycoerythrin (PE), CD45-fluorescein isothiocyanate (FITC), CD90-R-PE, CD73-PE, CD13-PE, CD44-PE, CD117-PE, human leukocyte antigen (HLA)-ABC-FITC, HLA-DR-R-PE (Becton, Dickinson and Company, Franklin Lakes, NJ, http:// www.bd.com). A total of 10,000 labeled cells were analyzed using a Guava EasyCyte flow cytometer running Guava ExpressPlus software (Guava Technologies Hayward, CA, http://www.guavatechnologies.com).

\section{Cell Differentiation Procedures}

To evaluate MSC properties, adherent cells (third passage, at $80-90 \%$ confluence) were subjected to adipogenic, chondrogenic, and osteogenic differentiation in vitro, according to established protocols $[4,11]$.

\section{RNA Preparation}

At $90 \%$ confluence, the MSC from four UC tissues and UCB paired samples $(n=4)$, at the second passage, were briefly rinsed with ice-cold PBS and lysed in TRIZOL reagent (Invitrogen, Carlsbad, CA, http://www.invitrogen. com) for RNA extraction. RNA purification and treatment with DNase I was performed in the 'on-column DNase digestion', according to protocol of the Qiagen RNeasy kit (Qiagen, Valencia, CA, USA). All RNA samples were checked for purity using a ND-1000 spectrophotometer (NanoDrop Technologies, Wilmington, DE, USA) and for integrity by electrophoresis on a 2100 BioAnalyzer (Agilent Technologies, Santa Clara, CA, USA).

Sample Labeling and Microarray Hybridization Procedures

Cy5- and Cy3-labeled cRNAs were obtained using $300 \mathrm{ng}$ total RNA as template for amplification of poly(A) RNA by
T7-RNA polymerase with the Agilent Low RNA Input Fluorescent Linear Amplification kit. The T7-polymerase amplified cRNA labeling approach advantageously replaces the reverse-transcriptase cDNA labeling used in early microarray experiments, because T7-RNA polymerase labeling of cRNA preserves the strand orientation of the original mRNA template. Reverse-transcriptase labeling can eventually generate a complementary cDNA second strand and cause artifactual labeling of a target with the opposite sense to that of the original message.

Hybridization of $825 \mathrm{ng}$ of Cy3- or Cy5-labeled RNA (dye swap technical replicate) from each UC sample with its paired UCB sample was performed with Agilent in situ Hybridization kit-plus, as recommended by the manufacturer, using a total of 4 intron-exon $44 \mathrm{~K}$ expression oligoarrays. This array comprises a total of 13,699 exonic probes representing different protein-coding genes, along with custom-designed intronic probes for the antisense or sense strand, as illustrated in Supplemental Figure 1 [37] (Figure S1).

Slides were washed and processed according to the Agilent Two-Color Microarray-Based Gene Expression Analysis protocol (Version 5.5) and scanned on a GenePix 4000B scanner (Molecular Devices, Sunnyvale, CA, USA). Fluorescence intensities were extracted using Feature Extraction (FE) software (version 9.0; Agilent). A gene was considered expressed if its probe intensity was significantly higher than the local background intensity, as calculated by the FE software. Then, the software applies local background subtraction and corrects for unequal dye incorporation using the default LOWESS (locally weighted linear regression) method. We have included into further statistical analyses only those genes that were detected as expressed in at least all UC samples or all CB samples as described below.

Microarray data has been deposited at the GEO database. The platform Access number is GPL9193 and the experimental series Access number is GSE18134.

\section{Statistical Analyses of Expression}

In order to identify differentially expressed transcripts between UC and UCB samples, we employed the Statistical Analysis of Microarray (SAM) approach [42] (http://wwwstat.stanford.edu/tibs/SAM/), using the following parameters: one-class analysis, 256 permutations, automatic K-Nearest Neighbors Imputer and a significance cutoff at 5\% False Discovery Rate. We performed a detailed functional annotation and description of the top 30 genes that were most significantly over-expressed in MSC from UC or UCB. To generate this list we started with the differentially expressed genes determined by the SAM analysis, ranked them by significance ( $q$-value) and subsequently by fold change, and 
we further eliminated the eventual duplicate probes for the same locus; the resulting two lists contain the 30 unique protein-coding genes over-expressed in MSC from either UC or UCB.

The set of differentially expressed protein-coding genes was further annotated by Gene Ontology (GO) terms and over-representation in functional categories was analyzed by hypergeometric distribution with the BenjaminiHochberg correction for multiple testing $(p \leq 0.05)$ using the eGOn tool [43]. Canonical pathways enrichment analyses of differentially expressed genes were performed using the Ingenuity Pathway Analysis (IPA) software (Ingenuity Systems, Redwood City, CA). This software uses a numerical value to rank the canonical pathways according to how relevant they are to the genes in the input dataset. The value is calculated taking into account the number of focus genes in the pathway and the size of the pathway in order to approximate how relevant this pathway is to the original list of focus genes. The significance value $(p \leq 0.05)$ is computed using the right-tailed Fisher's Exact Test and the $p$-value is corrected for multiple testing with the Benjamini-Hochberg method. The canonical pathway identified as significantly enriched $(p<0.05)$ is then presented as a graph indicating the molecular relationships between genes/gene products.

Using the SAM approach with the same parameters mentioned above, we found a very small number of intronic noncoding genes with statistically significant differential expression between UC and UCB samples (see Results). Therefore, in this case we chose to look for overrepresentation of GO functional categories and of enriched functions among the top 33\% most highly expressed intronic noncoding RNAs in each sample. For this purpose, each intronic noncoding transcript was functionally annotated according to the protein-coding gene of the same genomic locus and further classified by Gene Ontology terms.

\section{Real-Time Quantitative Polymerase Chain Reaction} Analysis

Differential expressions observed by microarray analysis were verified by Real-time Quantitative Polymerase Chain Reaction Analysis (RT-Q-PCR) for 7 differentially regulated genes and 1 housekeeping gene. Total RNA samples were reverse transcribed into cDNA using Superscript III reverse transcription kit (Invitrogen) and quantitative realtime PCR was performed using $1 \mu \mathrm{g}$ of cDNA and SYBR Green PCR master mix in an ABI Prism 7500 system (Applied Biosystems). Authenticity of the PCR products was verified by melt-curve analysis and agarose gel electrophoresis. Amplification efficiency of PCR products was determined by calculating the slope after semi- logarithmic plotting of the values against cycle number. Samples were run in triplicates, and the threshold suggested by the instrument software was used to calculate $\mathrm{Ct}$. Differential expression was calculated in relation to GAPDH. Data were analyzed statistically by MannWhitney test at a 0.05 level of significance. Primer sequences are provided in Supplemental Table 1 (Table S1).

\section{Results}

Isolation and Characterization of MSC from UC and UCB

MSC could be isolated from all 65 UC samples (100\%), but only from 6 out of 65 UCB samples (9\%). Previously, we had reported that the efficiency in isolating MSC from UCB stands around $10 \%$ [11].

All isolated MSC populations displayed a spindleshaped morphology (Fig. 1b, d). To evaluate MSC properties, their immunophenotype and differentiation capacity were considered. A panel of surface markers was tested by flow cytometry. MSC from all paired samples were negative for CD31 (endothelial cell marker), CD34, CD45, CD117 (hematopoietic cell markers), and HLA-DR (human leukocyte differentiation antigen class II), whereas they were positive for CD29, CD44 (adhesion markers), CD90, CD73, CD13 (mesenchymal markers), and HLAABC (human leukocyte differentiation antigen class I; Fig. 1a, c; Table 1). In vitro differentiation analysis confirmed that all isolated MSC from each matching units exhibited a comparable capacity to differentiate into osteoblasts, chondrocytes and adipocytes thus confirming their multipotent potential (Fig. 1e).

\section{Large-Scale Gene Expression Measurements in UC} and UCB Paired Samples

The observation that both populations of cells exhibit comparable properties and differentiation capacity, characteristic of MSC, does not exclude the possibility that they may differ in their potential to originate different cell lineages. To further evaluate how similar were MSC from UCB and UC paired samples, we examined their respective gene expression profiles $(n=4)$ using the $44 \mathrm{k}$ intron-exon oligoarray previously designed by our group [37].

A total of 38,960 probes are present in the oligoarray, comprising probes for exons of 13,699 protein-coding transcripts, along with 7,515 pairs of probes for totally intronic noncoding (TIN) transcripts, both for the sense (S-TIN) and anti-sense (AS-TIN) strands, plus 4,920 probes for antisense partially intronic noncoding (AS-PIN) transcripts (Table 2). The term AS-PIN is used to identify a transcript that overlaps an exon and is transcribed from the 
ô

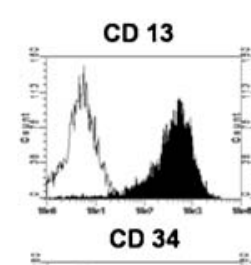

CD 29
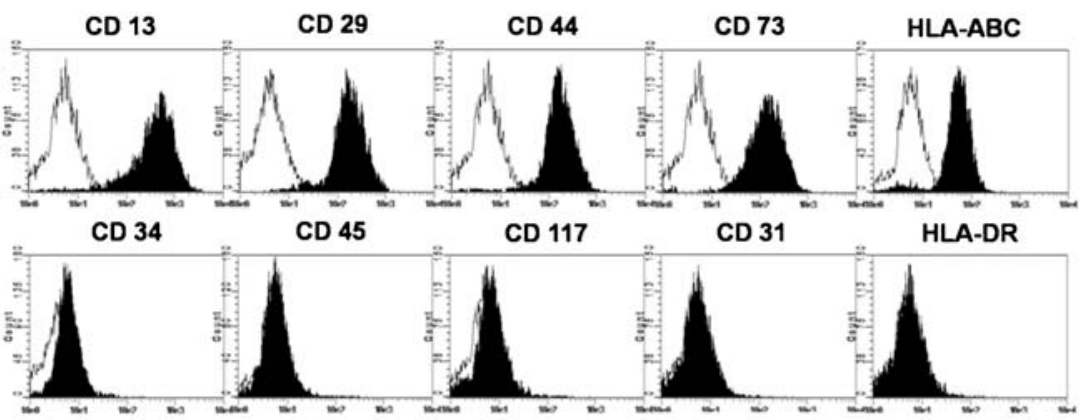

C

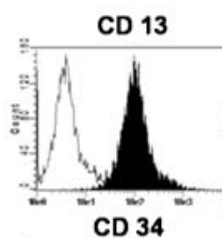

CD 29
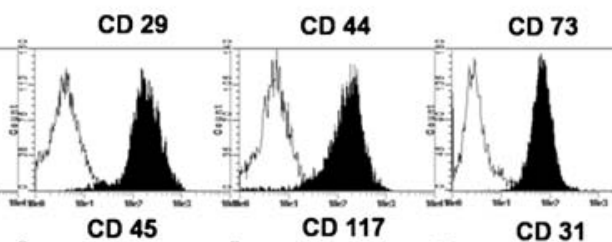

73

HLA-ABC
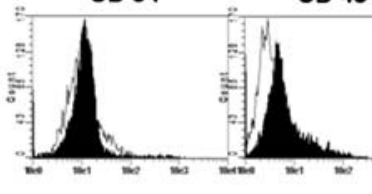

e
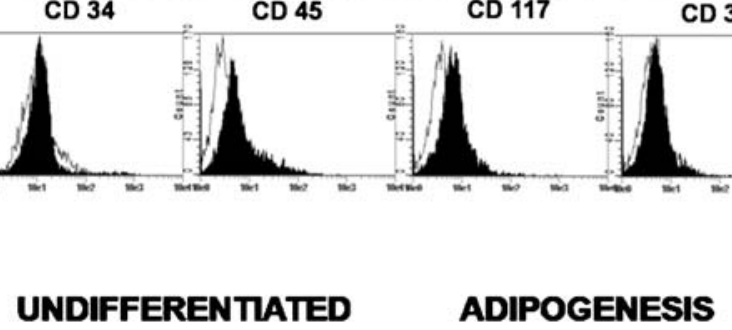

ADIPOGENESIS
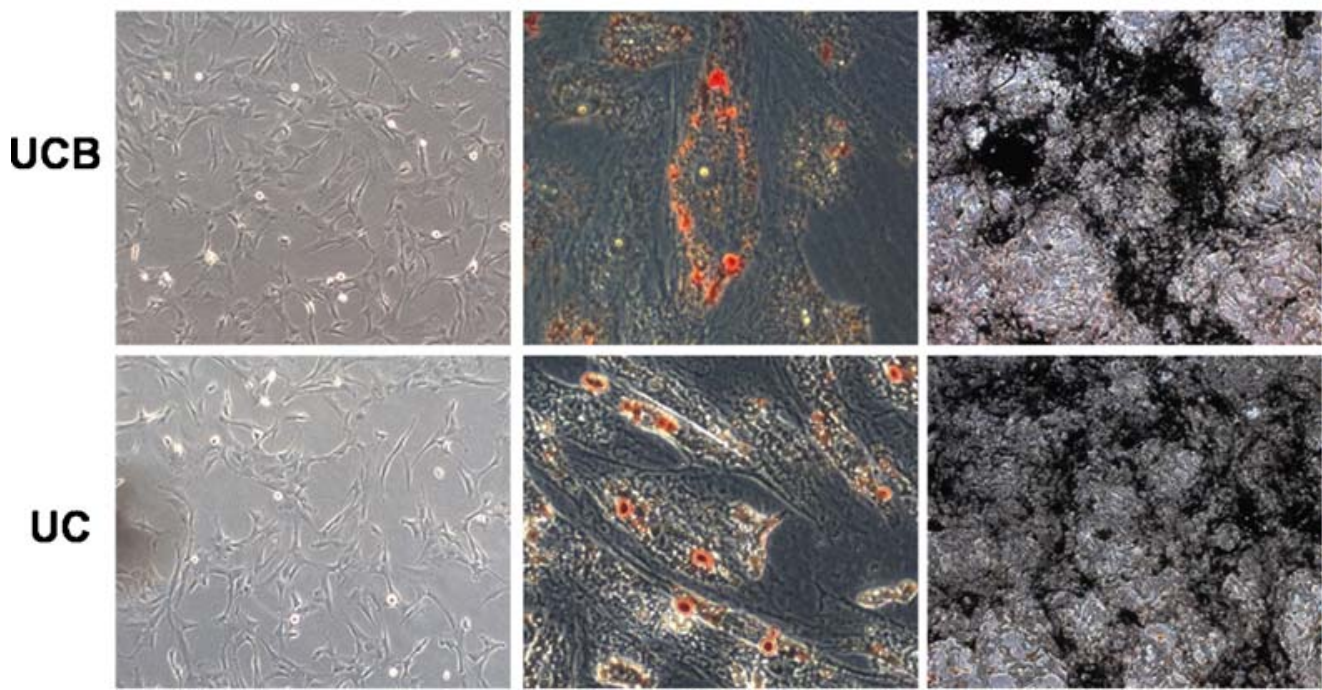

b

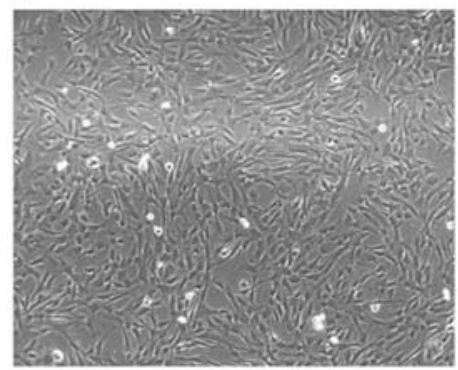

d

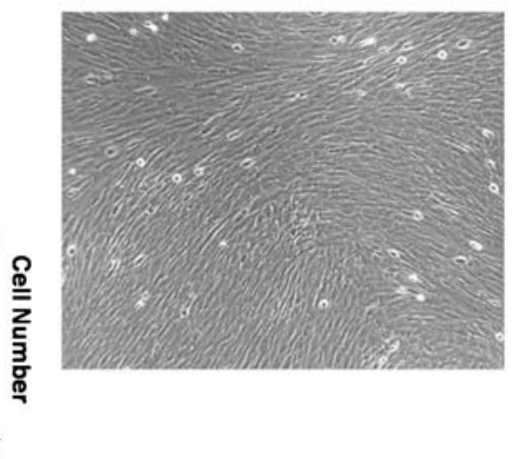

CHONDROGENESIS

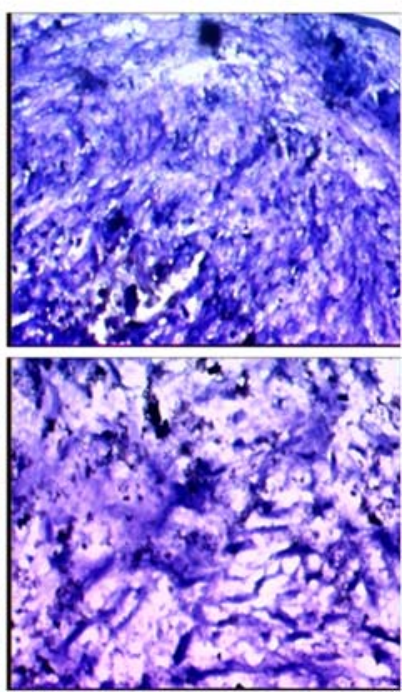

Fig. 1 Characterization of adherent cells isolated from UCB and UC. a, c Flow cytometric analysis of cell surface markers of MSC from UCB and UC, respectively. Representative histograms are demonstrated, and their respective controls are shown by the black lines. b, d Morphology of adherent cells isolated from UCB and UC. After 15 days in culture, all isolated MSC populations displayed a spindle-shaped morphology. e Differentiation potential of adherent cells isolated from UCB and UC. Osteogenic differentiation of adherent cells from UCB and UC was

opposite strand extending at least 30 bases into the adjacent introns over both ends of the exon [37] (Figure S1).

A total of 10,935 exonic, 1,645 AS-TIN, 2,651 AS-PIN and 2,420 S-TIN transcripts were found to be expressed in demonstrated by calcium deposition shown by von Kossa stain; Adipogenesis was detected by the formation of intracytoplasmic lipid droplets stained with oil red O; Cell spheres from UCB and UC were stained with toluidine blue to confirm chondrogenic differentiation. Mucopolysaccharide-rich extracellular matrix is shown in pinkish metachromatic areas. Abbreviations: $C D$ cluster of differentiation; $H L A-A B C$ human leukocyte antigen-ABC; HLA-DR human leukocyte antigen-DR; $U C B$ umbilical cord blood; $U C$ umbilical cord

UCB and UC samples (Table 2) and were further analyzed for differential expression as described in the next section.

Reproducibility in the microarray experiments was assessed by dye swap technical replicate using separately 
Table 1 Summary of surface markers expression in MSC from UCB and UC

\begin{tabular}{lrr}
\hline Surface Marker & UCB (\%) & UC (\%) \\
\hline Control & 0.84 & 0.98 \\
CD 13 & 98.18 & 96.64 \\
CD 29 & 97.88 & 97.94 \\
CD 44 & 97.72 & 97.18 \\
CD73 & 98.26 & 98.84 \\
CD 34 & 1.46 & 3.26 \\
CD 45 & 1.10 & 4.54 \\
CD 117 & 1.88 & 1.38 \\
CD 31 & 1.22 & 1.28 \\
HLA-ABC & 93.10 & 99.82 \\
HLA-DR & 1.68 & 1.94 \\
\hline
\end{tabular}

Data represent the mean of 3 different samples $(n=3)$. The results showed are percentage of positive cells

$H L A-A B C$ human leukocyte antigen-ABC; $H L A-D R$ human leukocyte antigen-DR; $U C$ umbilical cord; $U C B$ umbilical cord blood

prepared target RNA from each MSC sample. The correlation coefficient between two microarray datasets obtained from repeated experiments was greater than 0.98 , indicating that not only each microarray system per se, but also the overall experimental procedures were highly reproducible (Figure S2).

\section{Protein-Coding Expressed Transcripts}

The entire set of expressed protein-coding genes was used for a non-supervised hierarchical clustering analysis. The dendrogram in Fig. 2a evidences that MSC isolated from the same tissue (UC or UCB) clustered together, while MSC from different tissues of the same donor were found in different clusters.
These results indicated that gene expression profiles of MSC from the same tissue were more similar than those of MSC obtained from different tissues (UC versus UCB) of the same donor, suggesting the existence of a core gene expression profile for the MSC from each tissue, independent of the inter-donor differences.

In order to determine the statistical significance of such patterns, correlation coefficients were calculated for all possible combinations of expression measurements and a Student $t$-test was applied, as described below. Considering the exonic probes for protein-coding genes, the correlation coefficient among UC samples was in the range 0.899 to 0.972 (Table 3A, Figure S3 A). A similar trend was observed in the UCB group, where the correlation coefficient was in the range 0.901 to 0.955 (Figure $\mathrm{S} 3 \mathrm{D}$ ). In contrast, the correlation coefficient between paired UC versus UCB MSC samples from the same individuals (for example, $\mathrm{UC1}$ versus UCB1) was in the range 0.837 to 0.925 (Figure S3 B, C).

The correlation coefficient for comparisons within UC samples (Table 3A) was significantly higher than the correlation for comparisons between UC versus UCB within the same individual $(p=0.026)$ (Table $3 \mathrm{~A})$. A similar trend was observed for the UCB samples, although this difference was not statistically significant $(p=0.067)$ (Table $3 \mathrm{~A})$.

\section{Differential Gene Expression of Protein-Coding Genes in UC and UCB Tissues}

To identify the individual gene expression signature of each group of MSC, we used a one-class paired analysis with the SAM statistical approach (Fig. 3).

A total of 1,054 different protein-coding genes were expressed at significantly higher levels in MSC from UC while 816 genes were significantly higher in MSC from UCB (Table 2). The full list of differentially expressed genes is shown in Supplemental Table 2 (Table S2).

Table 2 Protein-coding and noncoding genes expressed in MSC from UC and UCB tissues

\begin{tabular}{|c|c|c|c|c|c|c|c|c|c|c|c|c|}
\hline & \multicolumn{2}{|l|}{ Exonic } & \multicolumn{8}{|c|}{ Intronic } & \multicolumn{2}{|c|}{ All ncRNAs } \\
\hline & \multirow[t]{2}{*}{ probes } & \multirow[t]{2}{*}{$\%$} & \multicolumn{2}{|c|}{ AS-TIN } & \multicolumn{2}{|l|}{ S-TIN } & \multicolumn{2}{|c|}{ AS-PIN } & \multicolumn{2}{|c|}{ Other ncRNA } & \multirow[b]{2}{*}{ probes } & \multirow[b]{2}{*}{$\%$} \\
\hline & & & probes & $\%$ & probes & $\%$ & probes & $\%$ & probes & $\%$ & & \\
\hline On the Array & 13699 & 100 & 7515 & 100 & 7515 & 100 & 4920 & 100 & 662 & 100 & 20612 & 100 \\
\hline \multirow[t]{2}{*}{ Expressed in UC and UCB } & 10935 & 80 & 1645 & 22 & 2420 & 32 & 2651 & 54 & 454 & 69 & 7170 & 35 \\
\hline & probes & $\%^{\mathrm{a}}$ & probes & $\%^{\mathrm{a}}$ & probes & $\%^{\mathrm{a}}$ & probes & $\%^{\mathrm{a}}$ & probes & $\%{ }^{\mathrm{a}}$ & probes & $\%{ }^{\mathrm{a}}$ \\
\hline Over-expressed in UC (FDR 5\%) & 1054 & 10 & 30 & 2 & 68 & 3 & 118 & 5 & 18 & 4 & 234 & 3 \\
\hline Over-expressed in UCB (FDR 5\%) & 816 & 8 & 25 & 2 & 124 & 5 & 51 & 2 & 19 & 4 & 219 & 3 \\
\hline Total differentially expressed & 1870 & 18 & 55 & 4 & 192 & 8 & 169 & 7 & 37 & 8 & 453 & 6 \\
\hline
\end{tabular}

$U C B$ umbilical cord blood; $U C$ umbilical cord

${ }^{\text {a }}$ Percent over-expressed probes is calculated in relation to the total number of probes of this category that are expressed in UC and UCB 

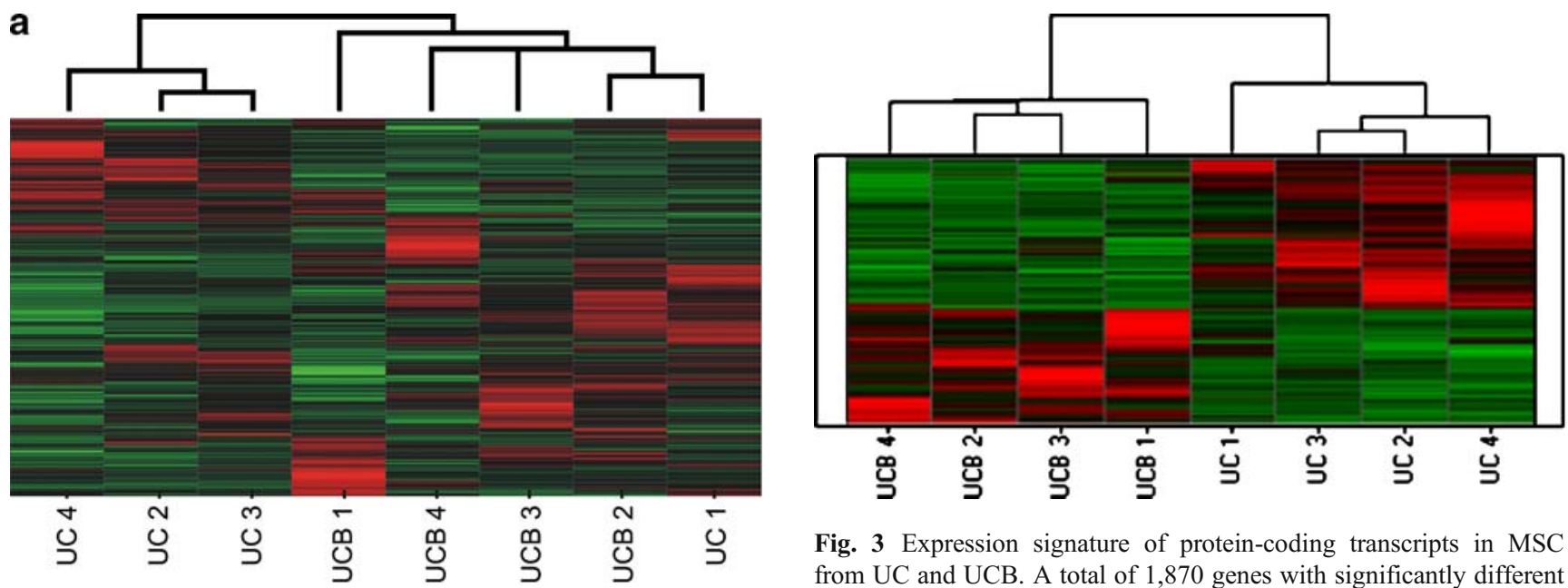

Fig. 3 Expression signature of protein-coding transcripts in MSC from UC and UCB. A total of 1,870 genes with significantly different levels among MSC from UC and UCB samples were identified by SAM one-class statistical analysis (FDR $<5 \%$ ) and hierarchically clustered as described in Materials and Methods. Each row represents the relative levels of expression for a single gene, calculated as the number of standard deviations above (red) or below (green) the average expression level of that gene across the samples. Each column represents the average expression of two technical replicate $(\mathrm{Cy} 3$ and Cy5) measurements of each sample

\section{Functional Annotation of Protein-Coding Genes Over-Expressed in MSC from UC}

Genes that were found to be over-expressed in MSC from UC were functionally annotated and analyzed with two different tools. First, enriched gene ontology (GO) terms were identified with the eGOn tool. A statistically significant over-representation of genes involved in morphogenesis, cell adhesion and secretion GO categories were identified (Table S3).

Next, the Ingenuity Pathway Analysis (IPA) software was used for identifying canonical pathways that were significantly enriched. We found that the "Synaptic Long Term Depression" pathway was significantly overrepresented (adjusted $p$-value $=0.042$ ). A total of 17 genes out of 139 genes in this pathway were found to be overexpressed in MSC from UC. A scheme of the pathway (Figure S4) and the full list of genes involved (Table S4) are shown.

Table 3 Correlation coefficients $\left(r^{2}\right)$ among expression profiles

Data shown are mean \pm SD from $r^{2}$ values within each group $\left(r^{2}\right.$ data from Figure S5)

$U C B$ umbilical cord blood; $U C$ umbilical cord

\begin{tabular}{lll}
\hline $\mathrm{r}^{2}$ within same tissue & $\mathrm{UC \text {vsUCB }}$ & $p$-value \\
& $\mathrm{r}^{2}$ within same donor \\
\hline
\end{tabular}

A) Protein-coding gene expression: analysis of correlations between MSC from UC and UCB
UC
$0.94 \pm 0.025$
$0.89 \pm 0.041$
0.026
UCB
$0.92 \pm 0.019$
$0.89 \pm 0.041$
0.067

B) Noncoding gene expression: analysis of correlations between MSC from UC and UCB
$\mathrm{UC}$
$0.98 \pm 0.005$
$0.99 \pm 0.006$
0.060
UCB
$0.98 \pm 0.007$
$0.99 \pm 0.006$
0.029 
Further, we ranked genes by significance (SAM $q$-value) and chose the top 30 genes that were significantly more expressed in MSC from UC (Table 4). The over- expressed genes in MSC from UC included genes involved in neurogenesis, such as SYNPO2 (synaptoidin) and NRP2, and angiogenesis, such as FLT1 (vascular endothelial growth factor-VEGF).

Functional Annotation of Protein-Coding Genes OverExpressed in MSC from UCB

Using a method similar to the aforementioned analysis of MSC from UC, we examined the gene expression profile of
MSC from UCB. Gene ontology analysis revealed a significantly higher representation of genes involved in anatomical structure development and multicellular organism development (Table S3). Using the Ingenuity Pathway Analysis (IPA) tool we could not find any significantly over-represented canonical pathway.

Among the top 30 genes that were significantly more expressed in MSC from UCB there were genes involved in osteogenesis, such as SPP1 (secreted phosphoprotein 1, osteopontin) and POSTN (periostin, osteoblast specific factor) (Table 5), and development of B-lymphoid cells, such as EBF1 and EBF3 (early B-cell factor 1,3 ).

Table 4 Top 30 over-expressed protein-coding genes in MSC from UC

\begin{tabular}{|c|c|c|c|c|c|}
\hline \multicolumn{6}{|c|}{ Overexpressed in UC } \\
\hline Entrez Gene ID & Gene Symbol & $\begin{array}{l}\text { Mapping. } \\
\text { location }\end{array}$ & Description & $\begin{array}{l}\text { SAM q-value } \\
(\%)\end{array}$ & $\begin{array}{l}\text { Fold } \\
\text { Change }\end{array}$ \\
\hline 139065 & SLITRK4 & $\mathrm{Xq} 27.3$ & SLIT and NTRK-like family, member 4 & 0 & 126.1 \\
\hline 590 & $\mathrm{BCHE}$ & $3 \mathrm{q} 26.1-\mathrm{q} 26.2$ & butyrylcholinesterase & 0 & 88.4 \\
\hline 10580 & SORBS1 & $10 \mathrm{q} 23.3-\mathrm{q} 24.1$ & sorbin and SH3 domain containing 1 & 0 & 57.8 \\
\hline 10788 & IQGAP2 & $5 \mathrm{q} 13.3$ & IQ motif containing GTPase activating protein 2 & 0 & 53.4 \\
\hline 2321 & FLT1 & $13 \mathrm{q} 12$ & $\begin{array}{l}\text { fms-related tyrosine kinase } 1 \text { (vascular endothelial } \\
\text { growth factor/vascular permeability factor receptor) }\end{array}$ & 0 & 52.7 \\
\hline 9699 & RIMS2 & $8 \mathrm{q} 22.3$ & regulating synaptic membrane exocytosis 2 & 0 & 27.2 \\
\hline 7980 & TFPI2 & $7 \mathrm{q} 22$ & tissue factor pathway inhibitor 2 & 0 & 25.7 \\
\hline 25849 & DKFZP564O0823 & $4 q 13.3-q 21.3$ & DKFZP564O0823 protein & 0 & 25.4 \\
\hline 753 & C18orf1 & $18 \mathrm{p} 11.2$ & chromosome 18 open reading frame 1 & 0 & 23.8 \\
\hline 171024 & SYNPO2 & $4 \mathrm{q} 26$ & synaptopodin 2 & 0 & 21.1 \\
\hline 57110 & HRASLS & $3 q 29$ & HRAS-like suppressor & 0 & 19.9 \\
\hline 144100 & PLEKHA7 & $11 \mathrm{p} 15.1$ & $\begin{array}{l}\text { pleckstrin homology domain containing, family } \\
\text { A member } 7\end{array}$ & 0 & 19.0 \\
\hline 244 & ANXA8 & $10 \mathrm{q} 11.2$ & annexin A8 & 0 & 17.4 \\
\hline 1803 & DPP4 & $2 \mathrm{q} 24.3$ & $\begin{array}{l}\text { dipeptidyl-peptidase } 4(\mathrm{CD} 26 \text {, adenosine deaminase } \\
\text { complexing protein } 2)\end{array}$ & 0 & 16.8 \\
\hline 55691 & FRMD4A & $10 \mathrm{p} 13$ & FERM domain containing $4 \mathrm{~A}$ & 0 & 16.1 \\
\hline 121551 & BTBD11 & $12 \mathrm{q} 23.3$ & BTB (POZ) domain containing 11 & 0 & 16.1 \\
\hline 50507 & NOX4 & $11 \mathrm{q} 14.2-\mathrm{q} 21$ & NADPH oxidase 4 & 0 & 15.1 \\
\hline 6653 & SORL1 & $11 \mathrm{q} 23.2-\mathrm{q} 24.2$ & $\begin{array}{l}\text { sortilin-related receptor, L(DLR class) A repeats- } \\
\text { containing }\end{array}$ & 0 & 14.9 \\
\hline 158038 & LRRN6C & $9 \mathrm{p} 21.2-\mathrm{p} 21.1$ & leucine rich repeat neuronal $6 \mathrm{C}$ & 0 & 14.7 \\
\hline 22998 & DKFZP686A01247 & $4 \mathrm{p} 13$ & hypothetical protein & 0 & 11.3 \\
\hline 104 & ADARB1 & $21 \mathrm{q} 22.3$ & $\begin{array}{l}\text { adenosine deaminase, RNA-specific, B1 (RED1 } \\
\text { homolog rat) }\end{array}$ & 0 & 11.2 \\
\hline 7163 & TPD52 & $8 \mathrm{q} 21$ & tumor protein D52 & 0 & 11.0 \\
\hline 23555 & TSPAN15 & $10 \mathrm{q} 21.3$ & tetraspanin 15 & 0 & 10.7 \\
\hline 55022 & FLJ20701 & $2 \mathrm{q} 36.3$ & hypothetical protein FLJ20701 & 0 & 9.4 \\
\hline 8828 & NRP2 & $2 \mathrm{q} 33.3$ & neuropilin 2 & 0 & 9.3 \\
\hline 54361 & WNT4 & $1 \mathrm{p} 36.23-\mathrm{p} 35.1$ & wingless-type MMTV integration site family, member 4 & 0 & 9.3 \\
\hline 256435 & ST6GALNAC3 & $1 \mathrm{p} 31.1$ & 1,3)-N-acetylgalactosaminide alpha-2,6-sialyltransferase 3 & 0 & 9.3 \\
\hline 5924 & RASGRF2 & $5 \mathrm{q} 13$ & Ras protein-specific guanine nucleotide-releasing factor 2 & 0 & 9.1 \\
\hline
\end{tabular}


Table 5 Top 30 over-expressed protein-coding genes in MSC from UCB

\begin{tabular}{|c|c|c|c|c|c|}
\hline Entrez Gene ID & $\begin{array}{l}\text { Gene } \\
\text { Symbol }\end{array}$ & $\begin{array}{l}\text { Mapping. } \\
\text { location }\end{array}$ & Description & $\begin{array}{l}\text { SAM q-value } \\
(\%)\end{array}$ & $\begin{array}{l}\text { Fold } \\
\text { Change }\end{array}$ \\
\hline 84302 & C9orf125 & $9 \mathrm{q} 31.1$ & chromosome 9 open reading frame 125 & 0 & 51.5 \\
\hline 81578 & COL21A1 & $6 \mathrm{p} 12.3-\mathrm{p} 11.2$ & collagen, type XXI, alpha 1 & 0 & 40.0 \\
\hline 3679 & ITGA7 & $12 \mathrm{q} 13$ & integrin, alpha 7 & 0 & 28.1 \\
\hline 79614 & C5orf23 & $5 \mathrm{p} 13.3$ & chromosome 5 open reading frame 23 & 0 & 25.7 \\
\hline 2044 & ЕРНА5 & $4 q 13.1$ & EPH receptor A5 & 0 & 25.0 \\
\hline 2006 & ELN & $7 q 11.23$ & elastin (supravalvular aortic stenosis, Williams-Beuren syndrome) & 0 & 23.9 \\
\hline 7373 & COL14A1 & $8 \mathrm{q} 23$ & collagen, type XIV, alpha 1 (undulin) & 0 & 23.9 \\
\hline 10631 & POSTN & $13 q 13.3$ & periostin, osteoblast specific factor & 0 & 22.3 \\
\hline 5168 & ENPP2 & $8 \mathrm{q} 24.1$ & ectonucleotide pyrophosphatase/phosphodiesterase 2 (autotaxin) & 0 & 16.7 \\
\hline 5137 & PDE1C & 7p15.1-p14.3 & phosphodiesterase $1 \mathrm{C}$, calmodulin-dependent $70 \mathrm{kDa}$ & 0 & 15.3 \\
\hline 8839 & WISP2 & 20q12-q13.1 & WNT1 inducible signaling pathway protein 2 & 0 & 15.2 \\
\hline 183 & AGT & $1 q 42-q 43$ & angiotensinogen (serpin peptidase inhibitor, clade A, member 8) & 0 & 14.4 \\
\hline 8490 & RGS5 & $1 \mathrm{q} 23.1$ & regulator of G-protein signalling 5 & 0 & 13.9 \\
\hline 182 & JAG1 & $20 \mathrm{p} 12.1-\mathrm{p} 11.23$ & jagged 1 (Alagille syndrome) & 0 & 13.1 \\
\hline 1879 & EBF1 & $5 \mathrm{q} 34$ & early B-cell factor 1 & 0 & 12.5 \\
\hline 253738 & EBF3 & $10 \mathrm{q} 26.3$ & early B-cell factor 3 & 0 & 12.3 \\
\hline 2012 & EMP1 & $12 \mathrm{p} 12.3$ & epithelial membrane protein 1 & 0 & 11.7 \\
\hline 6696 & SPP1 & $4 q 21-q 25$ & $\begin{array}{l}\text { secreted phosphoprotein } 1 \text { (osteopontin, bone sialoprotein I, } \\
\text { early T-lymphocyte activation 1) }\end{array}$ & 0 & 10.9 \\
\hline 23136 & EPB41L3 & $18 \mathrm{p} 11.32$ & erythrocyte membrane protein band 4.1-like 3 & 0 & 10.7 \\
\hline 3983 & ABLIM1 & $10 \mathrm{q} 25$ & actin binding LIM protein 1 & 0 & 10.5 \\
\hline 3783 & KCNN4 & $19 q 13.2$ & $\begin{array}{l}\text { potassium intermediate/small conductance calciumactivated } \\
\text { channel, subfamily } \mathrm{N} \text {, member } 4\end{array}$ & 0 & 10.2 \\
\hline 342184 & FMN1 & $15 \mathrm{q} 13.3$ & formin 1 & 0 & 10.1 \\
\hline 5328 & PLAU & $10 \mathrm{q} 24$ & plasminogen activator, urokinase & 0 & 9.2 \\
\hline 130916 & MTERFD2 & $2 \mathrm{q} 37.3$ & MTERF domain containing 2 & 0 & 8.6 \\
\hline 9510 & ADAMTS1 & $21 \mathrm{q} 21.2$ & ADAM metallopeptidase with thrombospondin type 1 motif, 1 & 0 & 8.5 \\
\hline 9783 & RIMS3 & 1 pter-p22.2 & regulating synaptic membrane exocytosis 3 & 0 & 7.9 \\
\hline 57520 & HECW2 & $2 \mathrm{q} 32.3-\mathrm{q} 33.1$ & HECT, $\mathrm{C} 2$ and WW domain containing E3 ubiquitin protein ligase 2 & 0 & 7.9 \\
\hline 4629 & MYH11 & $16 \mathrm{p} 13.11$ & myosin, heavy chain 11 , smooth muscle & 0 & 7.8 \\
\hline 255488 & IBRDC2 & $6 \mathrm{p} 22.3$ & IBR domain containing 2 & 0 & 6.8 \\
\hline
\end{tabular}

Partially and Totally Intronic Noncoding Transcripts Expressed in UC and UCB Paired Samples

Table 2 shows the number of protein-coding and intronic noncoding probes expressed in all UCB and UC samples. While $80 \%$ of protein-coding messages were expressed, only $22 \%$ of antisense TIN, $54 \%$ of antisense PIN and $32 \%$ of sense TIN transcripts were expressed in the tissues. This reveals that the diversity of intronic noncoding messages was lower than that of protein-coding messages.

We looked at the overall pattern of noncoding expression using a non-supervised hierarchical clustering (Fig. 2b). One can see that the MSC isolated from different tissues of the same donor clustered together while MSC from the same tissue and different donors were found in different clusters, thus suggesting that the intraindividual intronic noncoding expression profile was less variable between MSC from UC versus UCB than among the individuals.

The correlation coefficients between the UC and UCB paired samples from the same donor were in the range 0.9790.989 (Figure S5 B, C), while the correlation coefficients among the UCB samples from different donors were in the range 0.963-0.991 (Figure S5 A), and among UC samples in the range 0.967-0.987 (Figure S5 D). Table 3B shows that the average correlation coefficient between $\mathrm{UC}$ versus $\mathrm{UCB}$ of the same donors was significantly higher $(p=0.029)$ than the average correlation coefficient among MSC from UCBs of different donors. A similar comparison with the average 
correlation coefficient among MSC from UCs of different donors showed the same trend, although the difference was not statistically significant $(p=0.060)$ (Table 3B). The statistical analysis of correlation coefficients showed that the intronic noncoding expression profile was almost invariable among the individuals and even less variable between MSC from UC versus UCB of the same donor.

Using the same statistical significance analyses, a total of $4 \%$ expressed antisense PIN, 7\% antisense TIN and $8 \%$ sense TIN transcripts were detected as differentially expressed between UC and UCB paired samples, while $18 \%$ protein-coding transcripts were detected as differentially expressed in these samples (Table 2). This indicates that the tissue signature of intronic noncoding expression was more similar than the protein-coding messages between the UC and UCB paired samples.

Functional Annotation of ncRNA Over-Expressed in MSC from UCB and UC

The top 33\% most highly expressed TIN transcripts in each group of MSC (Table S5) were functionally annotated using Gene Ontology terms. The only statistically significant (adjusted $p$-value $=0.048$ ) enriched GO categories in MSC from UC comprise genes involved in transcription, including regulation of transcription, regulation of transcriptionDNA dependent, regulation of RNA metabolic process and biopolymer biosynthetic process (Table S6). The same GO categories were the most enriched ones in MSC from UCB, although this over-representation was not statistically significant (adjusted $p$-value $=0.153)$ (Table S6).

Next, the Ingenuity Pathway Analysis (IPA) software was used for identifying functions that were significantly enriched among the top 33\% most highly expressed TIN transcripts in MSC from UC and UCB. Functions related to Lymphoid Tissue Structure and Development, Cellular Development and Organ Development were shared between the samples from UC and UCB, while Visual System Development and Function was only enriched in UC. The entire list of identified functions and the genes involved are shown in Supplemental Tables 7 and 8 (Tables S7 and S8).

\section{Validation of Microarray Results with Real-Time} Quantitative PCR

Reproducibility of our microarray results has been shown to be fairly high [37] (Figure S2). Nevertheless, we have selected seven differentially expressed genes between UC and UCB samples and assessed their expression levels in $8 \mathrm{UC}$ and $6 \mathrm{UCB}$ units through RT-Q-PCR. Genes analyzed were significantly differentially expressed between UC and UCB samples $(p \leq 0.05$; Figure S6). The results were entirely consistent with DNA microarray data. Therefore, based on these results, we opted not to exhaustively reanalyze all genes of interest with RT-Q-PCR. In fact, recent microarray validation studies [44] have shown that the Agilent oligoarray technology, used in the present study, has been optimized to attain reproducible results.

\section{Discussion}

MSC are Isolated at Higher Yields from UC Compared with UCB

MSC have been defined by their plastic adherent growth and subsequent expansion under specific culture conditions, in addition to their in vitro differentiation potential into several cell types. Previous reports indicate that MSC can be found in perivascular niches of several organs [14-18] but they seem to be absent from the circulating blood under normal physiological conditions [17, 22]. However, their presence in UCB is controversial: some researchers successfully isolated MSC from UCB [23-25, 45], whereas others failed to isolate them or obtained a low yield [11, 22, 26, 27].

Based on a sample of 10 umbilical cord units, we had previously reported that under the same culture conditions, MSC could be obtained from all $10 \mathrm{UC}$ and, in contrast, from only one UCB [11, 12]. In the present study, these results were confirmed in a larger sampling, where MSC could be obtained from all 65 UC and from only 6 UCB. They support our previous observation on the importance of banking the whole umbilical cord unit as a source of MSC.

Genomic studies have provided another dimension for a detailed understanding of the MSC biology and ontogeny. Several authors have analyzed the gene expression profile of MSC, focusing mostly on three aspects: (i) changes induced during in vitro differentiation to specific cell lineages [46-50], (ii) direct comparison of gene expression profiles in population of MSC obtained from several sources [28-31, 45], and (iii) estimation of the absolute expression levels in MSC [30, 32, 33]. However these comparative studies were performed with different lineages of MSC obtained from various sources and processed under different conditions, which introduces many variables in the analysis of global gene expression profiles. A systematic comparison of the tissue expression signature of exonic and intronic noncoding transcripts of MSC derived from related sources and from match-paired samples analyzed under the same culture conditions had not been described previously.

Intronic Noncoding Transcripts are Abundantly Expresses in MSC from UC and UCB

We identified that $35 \%$ of all intronic noncoding transcripts on the array were expressed in MSC from UC and UCB, as 
opposed to $80 \%$ of exonic protein-coding genes on the array (Table 2). This reflects the fact that intronic noncoding RNAs have tissue and cell-type specific expression patterns, as demonstrated by our and other groups [34-38].

Interestingly, looking at the genomic loci of the most highly expressed noncoding transcripts in MSC from UC, the only statistically significant enriched GO categories were those associated with genes involved with regulation of transcription. The pattern found in MSC from umbilical cord samples is similar to that already observed for kidney, prostate and liver [37], emphasizing the importance of noncoding RNAs in providing an additional layer of regulatory functions in a number of different tissues [37, 51].

We also showed that both lineages of MSC share the high expression of a considerable number of intronic noncoding transcripts belonging to significantly enriched shared functional categories such as Lymphoid Tissue Structure and Development, Cellular Development and Organ Development (Tables S5, S6, S7 and S8), which supports a growing body of evidence in the literature indicating that the noncoding RNAs are related to the maintenance of pluripotency and the induction of alternative differentiation programs in stem cells [34]. Recently, Efroni et al. [52] demonstrated widespread transcription in protein-coding and noncoding regions in undifferentiated embryonic stem cells, whereas the lineage specification is driven by reduction of the transcribed portion of the genome. Since the MSC from UCB and UC analyzed here are undifferentiated and shared similar characteristics and differentiation potential, it seems reasonable that the most abundantly intronic expressed transcripts are, in fact, common to most of the cells in the culture instead of being expressed by a small subset of cells.

Nevertheless, the widespread expression of noncoding RNAs in undifferentiated cells and during the differentiation process support the hypothesis that these transcripts enclose several functions related to stem cells biology and therefore need to be considered to further understanding several fundamental biological processes of development, including ontogeny.

\section{Exonic Protein-Coding Expression Profile in MSC from UC Versus UCB}

Comparative correlation coefficients of exonic proteincoding expression profiles indicated that MSC from distinct UC samples are more similar to each other than to their UCB donor counterparts. In fact, MSC from different tissues (UC versus UCB) did not cluster together, even in paired MSC samples isolated from the same subject.

Previous studies comparing MSC obtained from unrelated individuals and different sources showed controversial results; Wagner et al. [53] demonstrated significant differences in the global gene expression patterns of MSC from adipose tissue, UCB and BM. Other studies have demonstrated that MSC populations obtained from different sources might exhibit significant differences in global gene expression patterns that are likely related to their differentiation capacities [3, 31, 54, 55]. On the other hand, some authors have reported that the gene expression profile of MSC of different sources were highly similar $[28,45]$. However, all these results should be regarded with caution, because the expression analysis was based on cell cultures obtained from different donors, and processed by different methodologies that might explain, at least in part, the observed diversity and/or similarity. Indeed, it had been previously reported that culture conditions have a significant impact on the gene expression profile [45]. Since the isolation of MSC is primarily based on adherence to plastic and growth under specific culture conditions, it is not surprising that culture media, the number of passages and growth factors might play a significant role in the selection of cell populations. To exclude such variables, all our experiments were performed in MSC isolated from the same donor, cultivated under the same culture conditions and processed in the same culture passage.

Despite that, our initial analysis using the entire set of expressed protein-coding genes demonstrated a significant difference in the exonic protein-coding transcript expression profiles of MSC from UC and UCB paired samples. Therefore, we have focused on the differentially expressed genes between them. Among the genes that were exclusively over-expressed in UCB are osteopontin and osteoblast specific factor, which are involved in osteogenesis. In fact, many of the integrin ligands implicated in the adherence of osteoblasts to the extracellular matrix are expressed at higher levels in MSC from UCB including type XXI and XIV collagen and alpha 7 integrin [55]. Other genes more expressed in UCB are EBF 1 and $E B F$ 3, recognized to be transcript factors related to development of B-lymphoid cells [56]. Given that UCB could be representing the neonatal defense system against the earliest encountered pathogens, it is not surprising that the genes related to the immune system were over-expressed in MSC from UCB.

Among the genes that were exclusively or expressed at higher levels by MSC from UC is FLT1 (vascular endothelial growth factor), a growth factor recognized to be a main regulator of angiogenesis [55]. Other genes more expressed in MSC from UC include SYNPO2, NRP2, $C D H 2$ and NPY [57-60]. All these genes could be related to neurogenesis or synaptic transmission and regulation of neurotransmitter secretion. In fact, the only significantly enriched canonical pathway related to the genes over- 
expressed in MSC from UC was "Synaptic Long Term Depression", a pathway of neurophysiological processes. It has been recently shown that MSC isolated from BM also can express neuronal markers without induction [61, 62]. Alternatively, considering the anatomic position of $\mathrm{BM}$, it is possible that their stroma is innervated and contains nerve terminals, which may be responsible for the expression of neuron-related proteins [31]. In any case, it will be of great interest to verify whether the differential expression of some tissue specific genes in MSC from distinct sources turns them more prone to differentiate into distinct cell lines. For example, MSC from UC, in their undifferentiated state, could be more appropriate for treatment of neurodegenerative syndromes while MSC from UCB could be more suitable for bone repair. In accordance to these findings, recent functional studies in vivo have indicated that MSC from UC may be therapeutically useful in treating central nervous systems disorders, which could be mediated by their ability to promote angiogenesis and/or neurogenesis [63-66].

Although MSC of both origins are highly similar in the noncoding transcript expression pattern, the differences in their respective protein-coding gene expression profiles might be due to the influence of the distinct local environment in which they are located, reflecting the importance of the niche in establishing the phenotype of its residing stem cells [67]. Functional classification of differentially expressed genes according to the Gene Ontology categories has demonstrated an enrichment of genes in the categories of development in UCB while cell adhesion, morphogenesis, and secretion in UC. In order to determine the role of individual genes on cell fate and differentiation potential, additional functional studies will be necessary and are currently underway.

\section{Origin of MSC in Umbilical Cord Blood}

Based on the technique used for cord blood harvesting, we had previously suggested that MSC from UCB might be derived from the umbilical cord tissue, which has been shown to be an alternative source for MSC [11]. However, results from the present study, demonstrating significant differences in the global gene expression patterns of MSC from UC and UCB paired samples, led us to suggest that these cells are not the same. The origin of MSC in UCB, however, remains to be elucidated.

Since the first report, several works have postulated that multipotent stem cells are present in the perivascular niche of various tissues [68]. The hypothesis that both hematopoietic and MSC are travelling, via cord blood, from early fetal hematopoietic sites to the newly formed bone marrow [24] suggests that MSC from UCB might be derived from the perivascular niche from fetal hematopoietic sites. The observation that the quantity of MSC in UCB decreases substantially with gestational age supports this hypothesis: the highest concentration of progenitors was observed during transition from hepatic to bone marrow hematopoiesis and the decline occurred with the termination of this process at birth [69-72]. Furthermore, several lines of evidence indicate that the MSC from UCB, liver and bone marrow are similar to those present in adult bone marrow. Despite the fact that MSC from UC and UCB are not the same cells, they may share a common origin, such as the perivascular niche.

The comparative gene expression profile observed in the present study provides additional support to this hypothesis. For example, the cluster analysis strongly indicates that MSC from UC and UCB share a close relationship based on the intronic noncoding transcripts, and this relationship may reflect their common ontogeny and differentiation status. On the other hand, clustering based on the protein-coding gene expression profiles could indicate the activation of specific sets of genes related to the tissue from which they were isolated.

\section{Conclusion}

In conclusion, we demonstrated, for the first time, that the intronic noncoding transcript expression patterns of MSC from UCB and UC paired samples are highly similar, suggesting that they share a common ontogeny and differentiation status. We showed significant differences in the protein-coding gene expression profile patterns of MSC from UC and UCB paired samples. A set of genes related to osteogenesis and immune systems was more expressed in MSC from UCB, whereas higher expression in MSC from UC tissue was observed for genes that participate in pathways related to angiogenesis and neurogenesis. These results suggest that MSC from a specific source may be more efficient for a particular therapeutic target, which may have important clinical implications. They reinforce our previous suggestion on the importance of keeping the whole umbilical cord unit by umbilical cord blood banks for research or future therapeutic uses, in addition to providing insight into MSC biology and ontogeny.

Acknowledgements Collaboration of the following persons is gratefully acknowledged: members from the Jesus José e Maria and University Hospital, Paula Onofre, Maria Denise Fernandes Carvalho, Marcos Valadares, Agnes Nishimura, Cleber Trujillo, Constancia Urbani, Daniela Bueno, Roberto Fanganiello, Antonia M. P. Cerqueira, Dr. Maria Rita Passos-Bueno and Dr. Mariz Vainzof for helpful suggestions. This work was supported by a grant from CEPID-FAPESP (Centro de Pesquisa, Inovação e Difusão-Fundação de Amparo a Pesquisa do Estado de São Paulo), and by grants from FAPESP, CNPq (Conselho Nacional de Desenvolvimento Científico e Tecnológico) and INCT (Instituto Nacional de Ciência e Tecnologia). 
Disclosures The authors indicate no potential conflicts of interest.

Open Access This article is distributed under the terms of the Creative Commons Attribution Noncommercial License which permits any noncommercial use, distribution, and reproduction in any medium, provided the original author(s) and source are credited.

\section{References}

1. Gang, E. J., Jeong, J. A., Hong, S. H., Hwang, S. H., Kim, S. W., Yang, I. H., et al. (2004). Skeletal myogenic differentiation of mesenchymal stem cells isolated from human umbilical cord blood. Stem Cells, 22, 617-624.

2. Karahuseyinoglu, S., Cinar, O., Kilic, E., Kara, F., Akay, G. G., Demiralp, D. O., et al. (2007). Biology of stem cells in human umbilical cord stroma: in situ and in vitro surveys. Stem Cells, 25, 319-331.

3. Kern, S., Eichler, H., Stoeve, J., Kluter, H., \& Bieback, K. (2006). Comparative analysis of mesenchymal stem cells from bone marrow, umbilical cord blood, or adipose tissue. Stem Cells, 24, 1294-1301.

4. Zuk, P. A., Zhu, M., Ashjian, P., De Ugarte, D. A., Huang, J. I., Mizuno, H., et al. (2002). Human adipose tissue is a source of multipotent stem cells. Mol Biol Cell, 13, 4279-4295.

5. Vieira, N. M., Brandalise, V., Zucconi, E., Jazedje, T., Secco, M., Nunes, V. A., et al. (2008). Human multipotent adipose-derived stem cells restore dystrophin expression of Duchenne skeletalmuscle cells in vitro. Biol Cell, 100, 231-241.

6. Vieira, N. M., Bueno, C. R., Jr., Brandalise, V., Moraes, L. V., Zucconi, E., Secco, M., et al. (2008). SJL dystrophic mice express a significant amount of human muscle proteins following systemic delivery of human adipose-derived stromal cells without immunosuppression. Stem Cells, 26, 2391-2398.

7. Kerkis, I., Kerkis, A., Dozortsev, D., Stukart-Parsons, G. C., Gomes Massironi, S. M., Pereira, L. V., et al. (2006). Isolation and characterization of a population of immature dental pulp stem cells expressing OCT-4 and other embryonic stem cell markers. Cells Tissues Organs, 184, 105-116.

8. Gronthos, S., Brahim, J., Li, W., Fisher, L. W., Cherman, N., Boyde, A., et al. (2002). Stem cell properties of human dental pulp stem cells. J Dent Res, 81, 531-535.

9. Jiang, Y., Jahagirdar, B. N., Reinhardt, R. L., Schwartz, R. E., Keene, C. D., Ortiz-Gonzalez, X. R., et al. (2002). Pluripotency of mesenchymal stem cells derived from adult marrow. Nature, 418, 41-49.

10. Lee, O. K., Kuo, T. K., Chen, W. M., Lee, K. D., Hsieh, S. L., \& Chen, T. H. (2004). Isolation of multipotent mesenchymal stem cells from umbilical cord blood. Blood, 103, 1669-1675.

11. Secco, M., Zucconi, E., Vieira, N. M., Fogaca, L. L., Cergueira, A., Carvalho, M. D., et al. (2008). Multipotent stem cells from umbilical cord: cord is richer than blood! Stem Cells, 26, 146-150.

12. Secco, M., Zucconi, E., Vieira, N. M., Fogaca, L. L., Cergueira, A., Carvalho, M. D., et al. (2008). Mesenchymal stem cells from umbilical cord: do not discard the cord! Neuromuscul Disord, 18 , 17-18.

13. Zuk, P. A., Zhu, M., Mizuno, H., Huang, J., Futrell, J. W., Katz, A. J., et al. (2001). Multilineage cells from human adipose tissue: implications for cell-based therapies. Tissue Eng, 7, 211-228.

14. Covas, D. T., Panepucci, R. A., Fontes, A. M., Jr Silva, W. A., Orellana, M. D., Freitas, M. C., et al. (2008). Multipotent mesenchymal stromal cells obtained from diverse human tissues share functional properties and gene-expression profile with CD146+ perivascular cells and fibroblasts. Exp Hematol, 36, 642-654.

15. Crisan, M., Yap, S., Casteilla, L., Chen, C.-W., Corselli, M., Park, T. S., et al. (2008). A perivascular origin for mesenchymal stem cells in multiple human organs. Cell Stem Cell, 3, 301-313.

16. da Silva Meirelles, L., Caplan, A. I., \& Nardi, N. B. (2008). In search of the in vivo identity of mesenchymal stem cells. Stem Cells, 26, 2287-2299.

17. da Silva Meirelles, L., Chagastelles, P. C., \& Nardi, N. B. (2006). Mesenchymal stem cells reside in virtually all post-natal organs and tissues. J Cell Sci, 119, 2204-2213.

18. da Silva Meirelles, L., Sand, T. T., Harman, R. J., Lennon, D. P., \& Caplan, A. I. (2008). MSC Frequency Correlates with Blood Vessel Density in Equine Adipose Tissue. Tissue Eng Part A.

19. Young, H. E., Ceballos, E. M., Smith, J. C., Mancini, M. L., Wright, R. P., Ragan, B. L., et al. (1993). Pluripotent mesenchymal stem cells reside within avian connective tissue matrices. In Vitro Cell Dev Biol Anim, 29A, 723-736.

20. Young, H. E., Mancini, M. L., Wright, R. P., Smith, J. C., Jr Black, A. C., Reagan, C. R., et al. (1995). Mesenchymal stem cells reside within the connective tissues of many organs. Dev Dyn, 202, 137-144.

21. Pate, D. W., Southerland, S., Grande, D. A., Young, H. E., \& Lucas, P. A. (1993). Isolation and differentiation of mesenchymal stem cells from rabbit muscle. Surg Forum, XLIV, 587.

22. Wexler, S. A., Donaldson, C., Denning-Kendall, P., Rice, C., Bradley, B., \& Hows, J. M. (2003). Adult bone marrow is a rich source of human mesenchymal 'stem' cells but umbilical cord and mobilized adult blood are not. Br J Haematol, 121, 368-374.

23. Bieback, K., Kern, S., Kluter, H., \& Eichler, H. (2004). Critical parameters for the isolation of mesenchymal stem cells from umbilical cord blood. Stem Cells, 22, 625-634.

24. Erices, A., Conget, P., \& Minguell, J. J. (2000). Mesenchymal progenitor cells in human umbilical cord blood. Br J Haematol, 109, 235-242.

25. Goodwin, H. S., Bicknese, A. R., Chien, S. N., Bogucki, B. D., Quinn, C. O., \& Wall, D. A. (2001). Multilineage differentiation activity by cells isolated from umbilical cord blood: expression of bone, fat, and neural markers. Biol Blood Marrow Transplant, 7, 581-588.

26. Mareschi, K., Biasin, E., Piacibello, W., Aglietta, M., Madon, E., \& Fagioli, F. (2001). Isolation of human mesenchymal stem cells: bone marrow versus umbilical cord blood. Haematologica, 86, $1099-1100$

27. Romanov, Y. A., Svintsitskaya, V. A., \& Smirnov, V. N. (2003). Searching for alternative sources of postnatal human mesenchymal stem cells: candidate MSC-like cells from umbilical cord. Stem Cells, 21, 105-110.

28. Jiang, Y., Vaessen, B., Lenvik, T., Blackstad, M., Reyes, M., \& Verfaillie, C. M. (2002). Multipotent progenitor cells can be isolated from postnatal murine bone marrow, muscle, and brain. Exp Hematol, 30, 896-904.

29. Majumdar, M. K., Thiede, M. A., Mosca, J. D., Moorman, M., \& Gerson, S. L. (1998). Phenotypic and functional comparison of cultures of marrow-derived mesenchymal stem cells (MSCs) and stromal cells. J Cell Physiol, 176, 57-66.

30. Tremain, N., Korkko, J., Ibberson, D., Kopen, G. C., DiGirolamo, C., \& Phinney, D. G. (2001). MicroSAGE analysis of 2, 353 expressed genes in a single cell-derived colony of undifferentiated human mesenchymal stem cells reveals mRNAs of multiple cell lineages. Stem Cells, 19, 408418.

31. Tsai, M. S., Hwang, S. M., Chen, K. D., Lee, Y. S., Hsu, L. W., Chang, Y. J., et al. (2007). Functional network analysis of the transcriptomes of mesenchymal stem cells derived from amniotic fluid, amniotic membrane, cord blood, and bone marrow. Stem Cells, 25, 2511-2523. 
32. Jia, L., Young, M. F., Powell, J., Yang, L., Ho, N. C., Hotchkiss, R., et al. (2002). Gene expression profile of human bone marrow stromal cells: high-throughput expressed sequence tag sequencing analysis. Genomics, 79, 7-17.

33. Wieczorek, G., Steinhoff, C., Schulz, R., Scheller, M., Vingron, M., Ropers, H. H., et al. (2003). Gene expression profile of mouse bone marrow stromal cells determined by cDNA microarray analysis. Cell Tissue Res, 311, 227-237.

34. Dinger, M. E., Amaral, P. P., Mercer, T. R., Pang, K. C., Bruce, S. J., Gardiner, B. B., et al. (2008). Long noncoding RNAs in mouse embryonic stem cell pluripotency and differentiation. Genome Res, 18, 1433-1445.

35. Brito, G. C., Fachel, A. A., Vettore, A. L., Vignal, G. M., Gimba, E. R., Campos, F. S., et al. (2008). Identification of protein-coding and intronic noncoding RNAs down-regulated in clear cell renal carcinoma. Mol Carcinog, 47, 757-767.

36. Mercer, T. R., Dinger, M. E., Sunkin, S. M., Mehler, M. F., \& Mattick, J. S. (2008). Specific expression of long noncoding RNAs in the mouse brain. Proc Natl Acad Sci U S A, 105, 716721.

37. Nakaya, H. I., Amaral, P. P., Louro, R., Lopes, A., Fachel, A. A., Moreira, Y. B., et al. (2007). Genome mapping and expression analyses of human intronic noncoding RNAs reveal tissue-specific patterns and enrichment in genes related to regulation of transcription. Genome Biol, 8, R43.

38. Birney, E., Stamatoyannopoulos, J. A., Dutta, A., Guigo, R., Gingeras, T. R., Margulies, E. H., et al. (2007). Identification and analysis of functional elements in $1 \%$ of the human genome by the ENCODE pilot project. Nature, 447, 799-816.

39. Yan, M. D., Hong, C. C., Lai, G. M., Cheng, A. L., Lin, Y. W., \& Chuang, S. E. (2005). Identification and characterization of a novel gene Saf transcribed from the opposite strand of Fas. Hum Mol Genet, 14, 1465-1474.

40. Ebralidze, A. K., Guibal, F. C., Steidl, U., Zhang, P., Lee, S., Bartholdy, B., et al. (2008). PU.1 expression is modulated by the balance of functional sense and antisense RNAs regulated by a shared cis-regulatory element. Genes Dev, 22, 2085-2092.

41. Hill, A. E., Hong, J. S., Wen, H., Teng, L., McPherson, D. T., McPherson, S. A., et al. (2006). Micro-RNA-like effects of complete intronic sequences. Front Biosci, 11, 1998-2006.

42. Tusher, V. G., Tibshirani, R., \& Chu, G. (2001). Significance analysis of microarrays applied to the ionizing radiation response. Proc Natl Acad Sci U S A, 98, 5116-5121.

43. Beisvag, V., Junge, F. K., Bergum, H., Jolsum, L., Lydersen, S., Gunther, C.-C., et al. (2006). GeneTools - application for functional annotation and statistical hypothesis testing. BMC Bioinformatics, 7, 470 .

44. Shi, L., Reid, L. H., Jones, W. D., Shippy, R., Warrington, J. A., Baker, S. C., et al. (2006). The MicroArray Quality Control (MAQC) project shows inter- and intraplatform reproducibility of gene expression measurements. Nat Biotechnol, 24, 1151-1161

45. Lee, R. H., Kim, B., Choi, I., Kim, H., Choi, H., Suh, K., et al. (2004). Characterization and expression analysis of mesenchymal stem cells from human bone marrow and adipose tissue. Cell Physiol Biochem, 14, 311-324.

46. Doi, M., Nagano, A., \& Nakamura, Y. (2002). Genome-wide screening by cDNA microarray of genes associated with matrix mineralization by human mesenchymal stem cells in vitro. Biochem Biophys Res Commun, 290, 381-390.

47. Nakamura, T., Shiojima, S., Hirai, Y., Iwama, T., Tsuruzoe, M., Hirasawa, A., et al. (2003). Temporal gene expression changes during adipogenesis in human mesenchymal stem cells. Biochem Biophys Res Commun, 303, 306-312.

48. Qi, H., Aguiar, D. J., Williams, S. M., La Pean, A., Pan, W., \& Verfaillie, C. M. (2003). Identification of genes responsible for osteoblast differentiation from human mesodermal progenitor cells. Proc Natl Acad Sci U S A, 100, 3305-3310.

49. Sekiya, I., Larson, B. L., Vuoristo, J. T., Cui, J. G., \& Prockop, D. J. (2004). Adipogenic differentiation of human adult stem cells from bone marrow stroma (MSCs). J Bone Miner Res, 19, 256-264.

50. Sekiya, I., Vuoristo, J. T., Larson, B. L., \& Prockop, D. J. (2002). In vitro cartilage formation by human adult stem cells from bone marrow stroma defines the sequence of cellular and molecular events during chondrogenesis. Proc Natl Acad Sci U S A, 99, $4397-4402$

51. Louro, R., Smirnova, A. S., \& Verjovski-Almeida, S. (2009). Long intronic noncoding RNA transcription: expression noise or expression choice? Genomics, 93, 291-298.

52. Efroni, S., Duttagupta, R., Cheng, J., Dehghani, H., Hoeppner, D. J., Dash, C., et al. (2008). Global transcription in pluripotent embryonic stem cells. Cell Stem Cell, 2, 437-447.

53. Wagner, W., Wein, F., Seckinger, A., Frankhauser, M., Wirkner, U., Krause, U., et al. (2005). Comparative characteristics of mesenchymal stem cells from human bone marrow, adipose tissue, and umbilical cord blood. Exp Hematol, 33, 1402-1416.

54. Chang, Y. J., Shih, D. T., Tseng, C. P., Hsieh, T. B., Lee, D. C., \& Hwang, S. M. (2006). Disparate mesenchyme-lineage tendencies in mesenchymal stem cells from human bone marrow and umbilical cord blood. Stem Cells, 24, 679-685.

55. Panepucci, R. A., Siufi, J. L., Silva, W. A., Jr., Proto-Sequiera, R., Neder, L., Orellana, M., et al. (2004). Comparison of gene expression of umbilical cord vein and bone marrow-derived mesenchymal stem cells. Stem Cells, 22, 1263-1278.

56. Bond, H. M., Mesuraca, M., Carbone, E., Bonelli, P., Agosti, V., Amodio, N., et al. (2004). Early hematopoietic zinc finger protein (EHZF), the human homolog to mouse Evi3, is highly expressed in primitive human hematopoietic cells. Blood, 103, 2062-2070.

57. Agasse, F., Bernardino, L., Kristiansen, H., Christiansen, S. H., Ferreira, R., Silva, B., et al. (2008). Neuropeptide Y promotes neurogenesis in murine subventricular zone. Stem Cells, 26, 16361645.

58. Ara, J., Bannerman, P., Shaheen, F., \& Pleasure, D. E. (2005). Schwann cell-autonomous role of neuropilin-2. J Neurosci Res, 79, 468-475.

59. Lim, S. T., Lim, K. C., Giuliano, R. E., \& Federoff, H. J. (2008). Temporal and spatial localization of nectin-1 and 1-afadin during synaptogenesis in hippocampal neurons. J Comp Neurol, 507, $1228-1244$.

60. Duband, J. L., Volberg, T., Sabanay, I., Thiery, J. P., \& Geiger, B. (1988). Spatial and temporal distribution of the adherens-junctionassociated adhesion molecule A-CAM during avian embryogenesis. Development, 103, 325-344.

61. Blondheim, N. R., Levy, Y. S., Ben-Zur, T., Burshtein, A., Cherlow, T., Kan, I., et al. (2006). Human mesenchymal stem cells express neural genes, suggesting a neural predisposition. Stem Cells Dev, 15, 141-164.

62. Tondreau, T., Lagneaux, L., Dejeneffe, M., Massy, M., Mortier, C., Delforge, A., et al. (2004). Bone marrow-derived mesenchymal stem cells already express specific neural proteins before any differentiation. Differentiation, 72, 319-326.

63. Weiss, M. L., Medicetty, S., Bledsoe, A. R., Rachakatla, R. S., Choi, M., Merchav, S., et al. (2006). Human umbilical cord matrix stem cells: preliminary characterization and effect of transplantation in a rodent model of Parkinson's disease. Stem Cells, 24, 781-792.

64. Fu, Y. S., Cheng, Y. C., Lin, M. Y., Cheng, H., Chu, P. M., Chou, S. C., et al. (2006). Conversion of human umbilical cord mesenchymal stem cells in Wharton's jelly to dopaminergic neurons in vitro: potential therapeutic application for Parkinsonism. Stem Cells, 24, 115-124.

65. Chen, M. Y., Lie, P. C., Li, Z. L., \& Wei, X. (2009). Endothelial differentiation of Wharton's jelly-derived mesenchymal stem cells 
in comparison with bone marrow-derived mesenchymal stem cells. Exp Hematol, 37, 629-640.

66. Liao, W., Xie, J., Zhong, J., Liu, Y., Du, L., Zhou, B., et al. (2009). Therapeutic effect of human umbilical cord multipotent mesenchymal stromal cells in a rat model of stroke. Transplantation, 87, 350359.

67. Fuchs, E., Tumbar, T., \& Guasch, G. (2004). Socializing with the neighbors: stem cells and their niche. Cell, 116, 769-778.

68. Abedin, M., Tintut, Y., \& Demer, L. L. (2004). Mesenchymal stem cells and the artery wall. Circ Res, 95, 671-676.

69. Campagnoli, C., Roberts, I. A., Kumar, S., Bennett, P. R., Bellantuono, I., \& Fisk, N. M. (2001). Identification of mesenchymal stem/progenitor cells in human first-trimester fetal blood, liver, and bone marrow. Blood, 98, 2396-2402.
70. Christensen, J. L., Wright, D. E., Wagers, A. J., \& Weissman, I. L. (2004). Circulation and chemotaxis of fetal hematopoietic stem cells. PLoS Biol, 2, E75.

71. Surbek, D. V., Holzgreve, W., Jansen, W., Heim, D., Garritsen, H., Nissen, C., et al. (1998). Quantitative immunophenotypic characterization, cryopreservation, and enrichment of second- and third-trimester human fetal cord blood hematopoietic stem cells (progenitor cells). Am J Obstet Gynecol, 179, 1228-1233.

72. Wyrsch, A., dalle Carbonare, V., Jansen, W., Chklovskaia, E., Nissen, C., Surbek, D., et al. (1999). Umbilical cord blood from preterm human fetuses is rich in committed and primitive hematopoietic progenitors with high proliferative and selfrenewal capacity. Exp Hematol, 27, 1338-1345. 


\section{Capítulo 4}

\section{EFEITOS DOS FATORES SOLÚVEIS LIBERADOS PELO MÚSCULO DISTRÓFICO NA INDUÇÃO DA PROLIFERAÇÃO E DIFERENCIAÇÃO MIOGÊNICA DE CÉLULAS-TRONCO MESENQUIMAIS HUMANAS}

Artigo em preparação para submissão - Setembro 2011

Soluble factors released from dystrophic muscle enhance the myogenic differentiation of human mesenchymal stromal cells

Mariane Secco, Carlos Bueno Júnior, Natassia M. Vieira, Marcos Valadares, Camila Almeida, Eder Zucconi, Oswaldo K. Okamoto, Mayana Zatz. 
ABSTRACT

Mesenchymal stromal cells (MSCs) therapy has been proposed for treatment of pathological conditions, including progressive muscular dystrophies (PMDs). Although MSCs have the ability to originate several mesoderm lineages, most recent studies have reported discrepant results about their myogenic differentiation after delivery into skeletal muscle. Here we investigated if factors released by degenerating dystrophic muscle might affect the myogenic potential of MSCs leading to impaired muscle regeneration. To address this question, we compared, for the first time, the effects of signals released from $m d x$ and LAMA2 $^{d y / 2 j}$ dystrophic muscle - murine models for Duchenne and Congenital Muscular Dystrophy, respectively - in the in vitro proliferation and myogenic differentiation of human umbilical cord derived-MSCs. Our results showed that soluble factors released from dystrophic muscle were able to promote an increase in the proliferation of MSCs. More interestingly, our data demonstrated that only soluble factors released from $m d x$ dystrophic muscle were able to promote an efficient terminal myogenic differentiation of MSCs. These findings have important implications for cell therapy and should be consider for future pre-clinical and clinical protocols since they may represent the cell transplantations success. 


\section{RESUMO}

O uso de células-tronco mesenquimais ou células estromais mesenquimais (MSCs; do inglês Mesenchymal Stem Cells) tem sido proposto para o tratamento de diversas condições patológicas, incluindo as distrofias musculares progressivas (PMDs; do inglês Progressive Muscular Dystrophies). Embora as MSCs possuam a habilidade de originar várias linhagens celulares de origem mesordérmica, resultados discrepantes têm sido reportados com relação a sua diferenciação miogênica após injeção no músculo distrófico. No presente estudo, nós investigamos se os fatores solúveis liberados pelo músculo distrófico são capazes de afetar o potencial miogênico das MSCs. Para isso, nós comparamos, pela primeira vez, os efeitos de meios condicionados preparados a partir do músculo de camundongos $m d x$ e LAMA2 $^{d y / 2 j}$ - modelos animais para a Distrofia Muscular de Duchenne e Congênita, respectivamente - na proliferação e diferenciação miogênica de MSCs. Nossos resultados mostraram que os fatores solúveis liberados pelo músculo distrófico são capazes de promover um aumento na proliferação de MSCs. Mais importante, nossos dados mostraram que somente os fatores solúveis liberados pelo músculo de camundongos $m d x$ foram capazes de promover a diferenciação miogênica terminal das MSCs humanas. Esses achados têm importantes implicações para a terapia celular e devem ser considerados para o planejamento de futuros protocolos pré-clínicos e clínicos, uma vez que podem significar o sucesso dos transplantes. 
Brief Article

Soluble factors released from dystrophic muscle enhance the myogenic differentiation of human mesenchymal stromal cells

Mariane Secco, Carlos Bueno Júnior, Natassia M. Vieira, Camila Almeida,

Marcos C. Valadares, Tatiana Jazedje, Oswaldo K. Okamoto, Mayana Zatz ${ }^{\dagger}$

1 Human Genome Research Center, Department of Genetic and Evolutive Biology, University of São Paulo, São Paulo, SP, Brazil.

\section{Keywords}

Human Mesenchymal stromal cells, myogenic differentiation, muscular dystrophy, IGF-1, TGF- $\beta$

†'Address correspondence to: Mayana Zatz, mayazatz@usp.br

Centro de Estudos do Genoma Humano, Departamento de Genética e Biologia Evolutiva, Universidade de São Paulo, São Paulo, SP, Brazil.

Rua do Matão, 106 - Cidade Universitária, 05508-090 São Paulo, SP, Brasil

Phone / fax number: (55) (11) 3091-7966

\section{Research support}

This work was supported by grants from CEPID-FAPESP (Centro de Pesquisa, Inovação e Difusão-Fundação de Amparo a Pesquisa do Estado de São Paulo), CNPq (Conselho Nacional de Desenvolvimento Científico e Tecnológico) and INCT (Instituto Nacional de Ciência e Tecnologia). 


\section{INTRODUCTION}

Adult skeletal muscle has the ability to regenerate itself after injury. This property is attributed to satellite cells, a subpopulation of undifferentiated mononuclear cells that surround muscle fibers. Most satellite cells are mitotically quiescent. However, in response to soluble factors released when muscle is damaged, they are activated, start to proliferate, undergo terminal differentiation, and fuse into new muscle fibers. The contribution of several growth factors and cytokines, deriving both from damage fibers and infiltrating inflammatory cells, has been pointed out as responsible for the establishment of a favorable microenvironment to initiate the muscle regeneration (Chargé and Rudnicki, 2004). In particular, IGF-1 is known to improve muscle repair, by inducing activation, enhancing the proliferation, myogenic differentiation and survival of the progenitor muscle cells (Mourkioti and Rosenthal, 2005). On the other hand, TGF- $\beta$, a fibrosis inductor, is a well-known potent inhibitor of myogenesis

(Tidball et al., 2005; Schabort et al., 2011; Gardner et al., 2011). Tissue regeneration depends on a precise balance between pro- and antiinflammatory/fibrotic factors that determine whether the damage is resolved or will induce scar formation (Mourkioti and Rosenthal, 2005; Pelosi et al., 2007; Schabort et al., 2011).

In pathological muscle conditions, such as muscular dystrophies, an intense and continuous degeneration of muscle fibers leads to a depletion of satellite cells and, therefore, the capacity to restore the skeletal muscle is lost (Heslop et al., 2000). It has been suggested that soluble factors released from dystrophic muscle as a result of marked degeneration and chronic inflammation 
may inhibit the proliferation and myogenic differentiation of satellite cells. Various muscle diseases, including Duchenne Muscular Dystrophy have been associated with muscle necrosis and fibrosis, and increased levels of TGF- $\beta$ (Bernasconi et al., 1995; Gosselin et al., 2004). Other evidences have indicated that the tissue niche is essential for controlling progenitor cells differentiation (Gharaibeh et al., 2011). Changes that occur in aged muscle environment have been previously shown to affect both early and late events in skeletal muscle regeneration. Parabiotic pairs of young and aged mice have showed that the sharing of the circulatory system allows "young" factors to act on the aged environment and improve skeletal muscle regeneration in aged mice (Conboy et al., 2005). Santa María et al. (2004) also showed that soluble factors released from chemically damaged but not undamaged muscle were able to induce the myogenic differentiation of rat progenitor cells.

Animal models for muscular dystrophies are important tools to understand how changes that occur in the skeletal muscle environment with disease progression may affect progenitor cells function and result in impaired muscle regeneration. For example, the $m d x$ mouse (murine $X$-linked muscular dystrophy) - the most widely used animal model for Duchenne Muscular Dystrophy (DMD) - is a very useful model to enhance our comprehension on muscle regeneration or maintenance, since these mice have a milder phenotype despite the complete absence of dystrophin (Vainzof et al., 2008). Corroborating the idea that the environment could affect muscle repair ability, previous studies have suggested that the mild progression of the muscular dystrophy condition in $m d x$ mice is due to their high muscle IGF-1 concentration that could contribute to effective muscle regeneration even in a later stagy of dystrophy (De Luca et 


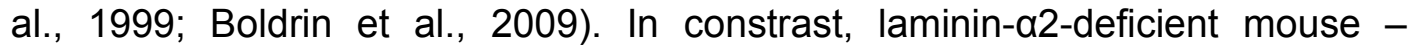
LAMA2 ${ }^{d y / 2 j}$, a murine model for Congenital Muscular Dystrophy - shows a severe muscle weakness and ineffective muscle regeneration probably due the markedly up-regulation of TGF- $\beta$ in the muscles (Sakuma et al., 2000).

Although several previously published studies have speculated about the effects of soluble factors released from the dystrophic muscle on the activation and myogenic differentiation of satellite cells, these events have not been analyzed in stem cells yet. Since in muscular dystrophy patients the muscle fibers degeneration exhausts the pool of satellite cells, the identification of alternative progenitor cell sources and understanding how the muscle environment can interfere in their myogenic potential is extremely important to evaluate cell therapy strategies.

The effects of mesenchymal stromal cells (MSCs), a population of adult stem cells obtained from different tissues, have been extensively investigated in various pre-clinical studies involving animal models of muscular dystrophy (Vieira et al., 2008; Kerkis et al., 2008; Gang et al., 2009; Vieira et al., 2010; Zucconi et al., 2011; da Justa Pinheiro et al., 2011). However, recent studies have demonstrated discrepant results regarding their myogenic differentiation after their delivery into skeletal muscle. According to some authors these cells would mediate tissue repair through their multilineage differentiation potential enabling them to replace damaged cells (Vieira et al., 2008; Vieira et al., 2011; Gang et al., 2009). Others suggest that this mechanism is unlikely and believe that in response to tissue injury, MSCs home to the site of damage and enhance repair through the production of trophic factors (Vieira et al., 2010; Gharaibeh et al., 2011; da Justa Pinheiro et al., 
2011; Caplan and Correa, 2011). Additionally, the success of stem cells transplantation could be also dependent of the host muscle environment (Gharaibeh et al., 2011).

To address this question, we analyzed "in vitro" the effects of soluble factors released from dystrophic muscle using conditioned medium prepared from $m d x$ and LAMA $2^{d y / 2 j}$ muscle in the MSCs myogenic differentiation capacity. Considering the phenotypic differences displayed between the $m d x$ and LAMA2 ${ }^{d y / 2 j}$ dystrophic mice, the comparison of their muscle environment could contribute to our knowledge about muscle regenerative capacity and cell transplantation outcomes.

\section{MATERIAL AND METHODS}

\section{Isolation and Characterization of human MSCs from umbilical cord}

All experiments were approved by the research ethics committee of the Biosciences Institute, University of São Paulo. All human samples were obtained after written informed consent from the donors. Human MSCs from umbilical cord were isolated and characterized using methods previously described (Secco et al., 2008, 2009).

\section{Preparation of conditioned medium from dystrophic muscle}

All tests involving animal models were conducted in accordance with the ethical principles in animal research adopted by the Brazilian College of Animal Experimentation (www.cobea.org.br). Conditioned medium was prepared from muscle of two-month old $m d x$ and LAMA $2^{d y / 2 j}$ dystrophic mice, 
according to protocols previously described. Briefly, the animals were sacrificed and both Tibialis Anterior (TA) muscles were excised by cutting the tendons. The whole muscle was placed into a glass beaker containing $1 \mathrm{~mL}$ of cold $\alpha$ MEM (Invitrogen-Gibco) and incubated with gentle stirring, for $2 \mathrm{~h}, 4-8^{\circ} \mathrm{C}$. The conditioned medium was collected by centrifugation, filtered through a $0,2 \mu \mathrm{m}$ filter, analyzed for protein content by BCA method, and stored at $-80^{\circ} \mathrm{C}$. The same procedure was followed for the preparation of a conditioned medium from C57BL/6J non-dystrophic control muscle (undamaged). Conditioned medium prepared from chemically damaged (CD) muscle was used as a positive control. The muscle chemical injury was performed by the administration of $25 \mu$ l of an aqueous solution of $\mathrm{BaCl}_{2}$ into both TA muscle of $\mathrm{C} 57 \mathrm{BL} / 6 \mathrm{~J}$ mice, according to Santa María et al. (2004). Two days post injection, the animals were sacrificed and their TA muscles were used for conditioned medium preparation.

\section{Proliferation and Myogenic Differentiation Assay In Vitro}

To evaluate and compare the effects of soluble factors released from dystrophic muscle on the proliferation and myogenic differentiation of MSCs, cells were plated in 6-wells plates and incubated in a-MEM containing $0,5 \%$ of Fetal Bovine Serum (FBS; Invitrogen-Gibco) alone (control) or supplemented with $0,5 \mathrm{mg} / \mathrm{mL}$ conditioned medium prepared from undamaged muscle, $m d x$ and LAMA2 ${ }^{d y / 2 j}$ dystrophic muscle and chemically damaged (CD) muscle. After 15 days, number and viability (Trypan blue staining) of adherent cells was assessed. In parallel studies, the expression of selected myogenic markers was analyzed by Western Blot and Immunofluorescence, as described below. 


\section{Western Blot Analysis}

Cell proteins were extracted through treatment with a buffer containing 10mM Tris- $\mathrm{HCl}(\mathrm{pH} 8.0), 150 \mathrm{mM} \mathrm{NaCl}, 5 \mathrm{mM}$ EDTA, 1\% Triton X-100 and $60 \mathrm{mM}$ octyl glucoside. Samples were centrifuged at $13,000 \times \mathrm{g}$ for 10 minutes to remove insoluble debris. Soluble proteins were resolved by $6 \%$ sodium dodecyl sulfate-polyacrylamide gel electrophoresis (SDSPAGE), and transferred to nitrocellulose membranes (Hybond; Amersham). Equal loading of samples $(50 \mu \mathrm{g})$ and transfer efficiency were monitored using $0.5 \%$ Ponceau $\mathrm{S}$ staining of the blotted membrane. Blots were blocked for 1 hour in Tris-buffered saline Tween (TBST) containing 5\% powdered skim milk and reacted overnight with the following primary antibodies: mouse monoclonal anti-MyoD $(2 \mu / \mathrm{mL}$; Becton Dickinson), mouse monoclonal anti-myogenin (1:200; Abcam), rabbit anti-desmin (1:100; Sigma-Aldrich); rabbit anti-Skeletal Myosin (1:50; SigmaAldrich). Blots were incubated one hour with secondary antibodies (horseradish peroxidase-conjugated antibody) and immunoreactive bands were detected with ECL chemiluminescence detection system (GE Healthcare). Quantitative analysis of human dystrophin at the host muscle was performed by using the ImageJ software (http://rsb.info.nih.gov/ij/), considering the Myosin at the Ponceau staining as a load protein control.

\section{Immunofluorescence}

Cells grown in a 1-chamber slides (Nalgene-NUNC) were fixed in $4 \%$ paraformaldehyde in PBS for $20 \mathrm{~min}$ at $4^{\circ} \mathrm{C}$ and permeabilized in $0,05 \%$ Triton X-100 in PBS for 5 minutes. Non-specific binding was blocked with $10 \%$ 
FBS in PBS for 1 hour at room temperature. Cells were incubated with primary antibody overnight at $4^{\circ} \mathrm{C}$ and with secondary antibody for 1 hour at room temperature. The following antibodies were used: Anti- Skeletal Myosin (1:20, Sigma), combined with goat anti-rabbit IgG secondary antibody, Cy3Conjugated (1:100, Chemicon). The fluorescence signal was examined in Axiovert 200 (Carl Zeiss) and in ApoTome Imaging System (Carl Zeiss).

\section{Enzyme-linked immunosorbent assay (ELISA)}

IGF-1 and TGF- $\beta$ in the conditioned medium were determined by enzyme-linked immunosorbent assay using a commercially available assay set (R\&D Systems Inc., Minneapolis, Minn). The process was performed according to the manufacturer's instructions. The results were compared with a standard curve constructed with mouse IGF-1 and TGF- $\beta$. Absorbance was measured at $450 \mathrm{~nm}$ by means of a microplate reader.

\section{Statistical Analysis}

All values are presented as means \pm standard error (SE). One-way ANOVA followed by Tukey's posttest were used to compare the groups. Statistical significance was considered as $p<0.05$. 


\section{RESULTS AND DISCUSSION}

A growing body of evidences suggests that cell therapy with MSCs might be beneficial for the treatment of neuromuscular conditions (Vieira et al., 2008; Kerkis et al., 2008; Gang et al., 2009; Vieira et al., 2010; Zucconi et al., 2011; da Justa Pinheiro et al., 2011; Caplan and Correa, 2011). However, the understanding of the mechanisms involved in stem cell differentiation after the delivery to skeletal muscle is a critical step towards clinical translation of cell therapies.

Here we cultured human MSCs from umbilical cord with conditioned medium prepared from $m d x$ and LAMA2 $2^{d y / 2 j}$ animal muscles dystrophic mice that present a mild and severe muscular dystrophy phenotype, respectively - in order to investigate if soluble factors released from dystrophic muscle with different degrees of severity could interfere in the proliferation and myogenic differentiation of MSCs. Other in vivo studies have already speculated that differentiation potential of MSCs seems to be strongly related to the microenvironment surrounding cells and signals (Gharaibeh et al., 2011). However, to the best of the knowledge, this is the first study comparing the effects of signals released from $m d x$ and LAMA $2^{d y / 2 j}$ dystrophic muscle in the in vitro myogenic differentiation of MSCs.

Muscle histological analysis illustrates some of the differences displayed by $m d x$ and LAMA2 ${ }^{d y / 2 j}$ mice. As showed in FIGURE 1, mdx muscle presents markedly more centronucleated fibers than LAMA2 ${ }^{d y / 2 j}$ mice, which characterizes pronounced muscle regeneration (FIGURE 1B,C). On the other hand, LAMA $2^{d y / 2 j}$ muscles show minor signs of regeneration, whereas the extent 
of interstitium and fibrosis is prominent (FIGURE 1B). These histological characteristics are consistent with the phenotypic differences exhibited by these animals (Vainzof et al., 2008).

The effects of dystrophic muscle on MSCs proliferation were studied after incubating cells in culture medium containing either $0,5 \%$ FBS alone (control) or supplemented with $0,5 \mathrm{mg} / \mathrm{mL}$ of conditioned medium from $m d x$ and LAMA2 ${ }^{d y / 2 j}$ muscle (FIGURE 2). At day 7, viable cells were counted after staining with Trypan blue. Since the effects of conditioned medium prepared from chemically damaged (CD) muscle on the proliferation and myogenic differentiation of rat MSCs were previously showed, it was used as a positive control.

Although not significant, our results demonstrated that MSCs proliferation was increased by soluble factors released from dystrophic muscle (FIGURE 2F). On the other hand, there was a significant increase in the MSCs proliferation when cultured in conditioned medium prepared from CD muscle, in comparison to control conditions (FIGURE 2F). This result is consistent with previously published data (Santa María et al., 2004).

At the molecular level, activation and proliferation of satellite cells is characterized by the rapid upregulation of MyoD and Myf5. The proliferative phase is followed by myoblast terminal differentiation, which is characterized by the expression of intermediate myogenic regulator factors, including MRF4 and Myogenin, and muscle-specific late proteins, such as Myosin Heavy Chain (MyHC) and Desmin (Chargé and Rudnicki, 2004). In order to understand how the soluble factors released from dystrophic muscle affect the myogenic differentiation, we analyzed the expression of MyoD, Myogenin, Desmin and 
MyHC in MSCs cultured in conditioned medium prepared from $m d x$ and LAMA2 ${ }^{d y / 2 j}$ muscle (FIGURE 3).

Our results demonstrated that Myogenin expression remained unchanged in MSCs culture in conditioned medium from both damaged and undamaged muscles, in comparison to control conditions (FIGURE 3A). In contrast, MSCs cultured in conditioned medium prepared from $m d x$ muscle presented a significant decrease of MyoD expression, while the Desmin and MyHC expression was notable increased (FIGURE 3A). In addition, continuous exposure of human MSCs to soluble factors released from $m d x$ dystrophic muscle resulted in the development of multinucleated MyHC-positive fibers on immunofluorescence staining (FIGURE 3F). These results suggest that only soluble factors released from $m d x$ dystrophic muscle were able to induce the terminal myogenic differentiation of MSCs.

Although MSCs cultured in conditioned medium from CD muscle presented an increase in Desmin expression, these values did not reach statistical significance. Based on our data, it seems that the effects of soluble factors released from CD muscle are limited to induce the cell proliferation. In contrast, Santa María et al. (2004) reported that conditioned medium prepared from chemically damaged rat muscle was able to induce the proliferation and myogenic differentiation of rat bone marrow derived-MSCs. Stem cells-source as well as the animal model used to prepare the conditioned medium can account for these discrepancies. Finally, we observed that the signals released from LAMA2 ${ }^{\text {dy/2j }}$ dystrophic muscle and undamaged muscle were not able to induce the activation, proliferation, neither terminal differentiation of MSCs, as 
demonstrated by the low expression of MyoD, Desmin and $\mathrm{MyHC}$ in these conditions (FIGURE 3).

In order to better understand these effects, we performed a quantitative analysis of IGF-1 and TGF- $\beta$ in the conditioned medium, since it has been previously reported that these growth factors participate in the myogenic differentiation of satellite cells (Mourkioti and Rosenthal, 2005; Tidball et al., 2005; Schabort et al., 2011). Our results demonstrated that conditioned medium prepared from two-month old $m d x$ dystrophic muscle had significant higher levels of IGF-1 in comparison to control muscle (FIGURE 4A). Conversely, TGF$\beta$ levels were reduced in $m d x$ muscle (FIGURE 4B). Considering the IGF-1 effects on the myogenic differentiation of satellite cells previously reported, our data suggest a direct causal link between the increase in IGF-I and the efficient myogenic conversion of MSCs promoted by conditioned medium obtained from muscle $m d x$ mice. Similarly, the significant high levels of TGF- $\beta$ reported in LAMA $^{d y / 2 j}$ muscles (FIGURE 4B) could be associated with failed myogenesis of MSCs after exposure to conditioned medium prepared from these dystrophic mice. In chemically damaged muscle, we showed an increase of both IGF-1 and TGF- $\beta$ levels (FIGURE 4A,B). Whereas the myogenesis induced by soluble factors released from CD muscle was not as efficient as that induced by $m d x$ soluble factors, we could assume that TGF- $\beta$ and IGF-1 display opposite effects. In fact, recent studies showed that TGF- $\beta$ inhibit IGF-1-induced myogenic differentiation (Schabort et al., 2011; Gardner et al., 2011). Altogether our results provide evidence that IGF-1 contributes to induce the myogenic differentiation of MSCs. Further investigations are of utmost importance to confirm these data. 
Finally, we also analyzed the IGF-1 levels in different stages during the course of muscular dystrophy. We showed that IGF-1 levels in $m d x$ muscle increase significantly between 1 and 2 months of age, and these levels remained high in animals up to at least 6 months of age (FIGURE 4C). Interestingly, it has been previously shown that $m d x$ dystrophic mice presents a spontaneous and effective regeneration, particularly between 8th-10th weeks of age in hind limbs (De Luca et al., 1999), which correspond to the greatest IGF-1 concentration detected in the present study (FIGURE 4C). These results strongly support a role of IGF-1 in the spontaneous regeneration process which occurs in $m d x$ mice during the 2 nd month. In contrast, the LAMA $2^{d y / 2 j}$ presents significantly low IGF-1 levels between 1 and 6 months of age (FIGURE 4C) and, consistently, this murine model develops severe muscle weakness at about 3 weeks of age (Vainzof et al., 2008).

Other researches have already reported the crucial role of IGF-1 in muscle regeneration. For example, the immunoneutralization of IGF-I markedly delayed the recovery of damaged muscle. Moreover, supplemental expression of IGF-1 transgene in damaged muscle increased its regeneration capacity, reducing the replacement of muscle fibers by fibrotic tissue, suggesting that prevention of fibrosis can improve muscle healing (Mourkioti and Rosenthal, 2005; Barton et al., 2002). On the other hand, TGF- $\beta$ high levels we found in LAMA $^{d y / 2 j}$ dystrophic mice are consistent with the prominent fibrosis established in their muscle since the up-regulation of this cytokine has been associated to increased fibrogenesis (Prisk and Huard, 2003). The FIGURE 4D, illustrates a schematic representation of muscle repair, emphasizing the role of IGF-1 and TGF- $\beta$ in this process. 
In short, our results strongly suggest that changes occurring in skeletal muscle during the progression of the dystrophic process may affect stem cells proliferation and myogenic differentiation and, therefore, should be considered in future pre-clinical or clinical cell therapy protocols. For example, animals with a severe phenotype such as LAMA2 ${ }^{d y / 2 j}$ dystrophic mice and their human counterpart - congenital muscular dystrophy $1 \mathrm{~A}-$ might not be effectively treated only by stem cells. Modifying the skeletal muscle environment - for example, through the association of IGF-1 - the stem cell therapy may be a very promising approach for an effective treatment for different forms of muscular dystrophies.

\section{Acknowledgements}

The collaboration of the following persons is gratefully acknowledged: Members from University Hospital, Constancia Urbani, Estela Cruvinel, Mayra Pellati, Carla Freitas, Juliana Gomes, Amanda Assoni, Gabriela Polster, Heloisa Caetano, Paula Onofre, Marta Canovas, Dra. Maria Rita Passos-Bueno, Dr. Mariz Vainzof, for helpful suggestions. This work was supported with grants of CEPID-FAPESP (Centro de Pesquisa, Inovação e Difusão-Fundação de Amparo a Pesquisa do Estado de São Paulo), CNPq (Conselho Nacional de Desenvolvimento Científico e Tecnológico), INCT (Instituto Nacional de Ciência e Tecnologia).

\section{Disclosures}

The authors indicate no potential conflicts of interest. 


\section{REFERENCES:}

Barton, E.R., Morris, L., Musaro, A., Rosenthal, N., and Sweeney, H.L. (2002). Muscle-specific expression of insulin-like growth factor I counters muscle decline in mdx mice. J. Cell Biol. 157, 137-148.

Bernasconi, P., Torchiana, E., Confalonieri, P., Brugnoni, R., Barresi, R., Mora, M., Cornelio, F., Morandi, L., and Mantegazza, R. (1995). Expression of transforming growth factor-beta 1 in dystrophic patient muscles correlates with fibrosis. Pathogenetic role of a fibrogenic cytokine. J. Clin. Invest. 96, 11371144.

Boldrin, L., Zammit, P.S., Muntoni. F., and Morgan, J.E. (2009). Mature adult dystrophic mouse muscle environment does not impede efficient engrafted satellite cell regeneration and self-renewal. Stem Cells. 27, 2478-2487.

Caplan, A.I., and Correa, D. (2011). The MSC: an injury drugstore. Cell Stem Cell 9, 11-15.

Chargé, S.B., and Rudnicki, M.A. (2004). Cellular and molecular regulation of muscle regeneration. Physiol. Rev. 84, 209-238.

Conboy, I.M., Conboy, M.J., Wagers, A.J., Girma, E.R., Weissman, I.L., and Rando, T.A. (2005). Rejuvenation of aged progenitor cells by exposure to a young systemic environment. Nature 433, 760-764.

Da Justa Pinheiro, C.H., De Queiroz, J.C., Guimarães-Ferreira, L., Vitzel, K.F., Nachbar, R.T., De Sousa, L.G., De Souza-Jr, A.L., Nunes, M.T., and Curi, R. (2011). Local Injections of Adipose-Derived Mesenchymal Stem Cells Modulate Inflammation and Increase Angiogenesis Ameliorating the Dystrophic Phenotype in Dystrophin-Deficient Skeletal Muscle. Stem Cell Rev. [Epub ahead of print].

De Luca, A., Pierno, S., Camerino, C., Cocchi, D., and Camerino, D.C. (1999). Higher content of insulin-like growth factor-I in dystrophic mdx mouse: potential role in the spontaneous regeneration through an electrophysiological investigation of muscle function. Neuromuscul. Disord. 9, 11-18.

Gang, E.J., Darabi, R., Bosnakovski, D., Xu, Z., Kamm, K.E., Kyba, M., and Perlingeiro, R.C., (2009). Engraftment of mesenchymal stem cells into dystrophin-deficient mice is not accompanied by functional recovery. Exp. Cell Res. 315, 2624-2636. 
Gardner, S., Alzhanov, D., Knollman, P., Kuninger, D., and Rotwein, P. (2011). TGF- $\beta$ inhibits muscle differentiation by blocking autocrine signaling pathways initiated by IGF-II. Mol. Endocrinol. 25, 128-137.

Gharaibeh, B., Lavasani, M., Cummins, J.H., and Huard, J. (2011). Terminal differentiation is not a major determinant for the success of stem cell therapy - cross-talk between muscle-derived stem cells and host cells. Stem Cell Res. Ther. 2, 31.

Gosselin, L.E., Williams, J.E., Deering, M., Brazeau, D., Koury, S., and Martinez, DA. (2004). Localization and early time course of TGF-beta 1 mRNA expression in dystrophic muscle. Muscle Nerve 30, 645-653.

Heslop, L., Morgan, J.E., and Partridge, T.A. (2000). Evidence for a myogenic stem cell that is exhausted in dystrophic muscle. Journal of Cell Science 113, 2299-2308.

Kerkis, I., Ambrosio, C.E., Kerkis, A., Martins, D.S., Zucconi, E., Fonseca, S.A., Cabral, R.M., Maranduba, C.M., Gaiad, T.P., Morini, A.C., et al. (2008). Early transplantation of human immature dental pulp stem cells from baby teeth to golden retriever muscular dystrophy (GRMD) dogs: local or systemic? J. Transl. Med. 6, 35.

Mourkioti, F., and Rosenthal, N. (2005). IGF-1, inflammation and stem cells: interactions during muscle regeneration. Trends Immunol 26, 535-42.

Pelosi, L., Giacinti, C., Nardis, C., Borsellino, G., Rizzuto, E., Nicoletti, C., Wannenes, F., Battistini, L., Rosenthal, N., Molinaro, M., et al. (2007). Local expression of IGF-1 accelerates muscle regeneration by rapidly modulating inflammatory cytokines and chemokines. FASEB J. 21, 1393-1402.

Prisk, V., and Huard, J. (2003). Muscle injuries and repair: the role of prostaglandins and inflammation. Histol. Histopathol. 18, 1243-1256.

Sakuma, K., Watanabe, K., Sano, M., Uramoto, I., and Totsuka, T. (2000). Postnatal profiles of myogenic regulatory factors and the receptors of TGF-beta 2, LIF and IGF-I in the gastrocnemius and rectus femoris muscles of dy mouse. Acta Neuropathol. 99, 169-176.

Santa María, L., Rojas, C.V., and Minguell, J.J. (2004). Signals from damaged but not undamaged skeletal muscle induce myogenic differentiation of rat bonemarrow-derived mesenchymal stem cells. Exp. Cell Res. 300, 418-426. 
Secco, M., Moreira, Y.B., Zucconi, E., Vieira, N.M., Jazedje, T., Muotri, A.R., Okamoto, O.K., Verjovski-Almeida, S., and Zatz, M. (2009). Gene expression profile of mesenchymal stem cells from paired umbilical cord units: cord is different from blood. Stem Cell Rev. 5, 387-401.

Secco, M., Zucconi, E., Vieira, N.M., Fogaça, L.L., Cerqueira, A., Carvalho, M.D., Jazedje, T., Okamoto, O.K., Muotri, A.R., and Zatz, M. (2008). Multipotent stem cells from umbilical cord: cord is richer than blood! Stem Cells. 26, 146150.

Schabort, E.J., Van der Merwe, M., and Niesler, C.U. (2011). TGF- $\beta$ isoforms inhibit IGF-1-induced migration and regulate terminal differentiation in a cellspecific manner. J. Muscle Res. Cell Motil. 31, 359-367.

Tidball, J.G. (2005). Inflammatory processes in muscle injury and repair. Am. J. Physiol. Regul. Integr. Comp. Physiol. 288, 345-353.

Vainzof, M., Ayub-Guerrieri, D., Onofre, P.C., Martins, P.C., Lopes, V.F., Zilberztajn, D., Maia, L.S., Sell, K., and Yamamoto, L.U. (2008). Animal models for genetic neuromuscular diseases. J. Mol. Neurosci. 34, 241-248.

Vieira, N. M., Bueno, C.R. Jr., Brandalise, V., Moraes, L.V., Zucconi, E., Secco, M., Suzuki, M.F., Camargo, M.M., Bartolini, P., Brum, P.C., et al. (2008). Sjl dystrophic mice express a significant amount of human muscle proteins following systemic delivery of human adipose-derived stromal cells without immunosupression. Stem Cells 26, 2391-2398.

Vieira, N.M., Zucconi, E., Bueno, C.R. Jr., Secco, M., Suzuki, M.F., Bartolini, P., Vainzof, M., and Zatz, M. (2010) Human multipotent mesenchymal stromal cells from distinct sources show different in vivo potential to differentiate into muscle cells when injected in dystrophic mice. Stem Cell Rev. 6, 560-566.

Vieira, N. M., Valadares, M., Zucconi, E., Secco, M., Bueno, C.R. Jr., Brandalise, V., Assoni, A., Gomes, J., Landini, V., Andrade, T., et al. (2011). Human Adipose-Derived Mesenchymal Stromal cells injected systemically into GRMD dogs without immunosupression are able to reach the host muscle and express human dystrophin. Cell Transplant. [Epub ahead of print].

Zucconi, E., Vieira, N.M., Bueno, C.R. Jr., Secco, M., Jazedje, T., Costa Valadares, M., Fussae Suzuki, M., Bartolini, P., Vainzof, M., and Zatz, M. (2011). Preclinical studies with umbilical cord mesenchymal stromal cells in different animal models for muscular dystrophy. J. Biomed. Biotechnol. 2011:715251. 


\section{Figure Legends}

Figure 1: Histological analysis of undamaged and damaged muscle. (A-D) Representative H\&E cross sections of Tbialis Anterior (TA) muscle from undamaged, LAMA $2^{d y / 2 j}$ and $m d x$ dystrophic mice and chemically damaged mice (CD). Scale bar $=100 \mu \mathrm{m}$.

Figure 2: Signals released from chemically damaged muscle are able to promote the proliferation of MSCs. (A-E) Cells $\left(1000 \mathrm{cells} / \mathrm{cm}^{2}\right)$ were incubated in culture medium containing 0,5\% FBS alone (control) or supplemented with $0,5 \mathrm{mg} / \mathrm{mL}$ of conditioned medium prepared from undamaged muscle, LAMA2 ${ }^{d y / 2 j}$ and $m d x$ dystrophic muscle, and chemically damaged muscle (CD). Phase-contrast microscopy images were taken at day 7 of incubation. Scale Bar $=200 \mu \mathrm{m} ; \mathrm{F}$ ) Viable cells were counted after staining with Trypan blue. Data represent mean cell number \pm SE, of three experiments $(n=3)$, performed in duplicate. ${ }^{*} P<0.05$ versus control cells; one-way ANOVA.

Figure 3: Signals released from $\mathbf{m d x}$ dystrophic muscle are able to induce the terminal myogenic differentiation of MSCs. (A) Western Blot analysis of MyoD, Myogenin, Desmin and MyHC (Myosin Heavy Chain) expression in MSCs cultured in culture medium containing 0,5\% Fetal Bovine Serum (FBS) alone (control) or supplemented with $0,5 \mathrm{mg} / \mathrm{ml}$ of conditioned medium from undamaged muscle, LAMA $2^{d y / 2 j}$ and $m d x$ dystrophic muscle and chemically damaged muscle $(C D)$. Data represent mean \pm SE, of four experiments $(n=4)$. ${ }^{*} \mathrm{P}<0.05$, versus control cells; one-way ANOVA; (B) Representative Western 
Blot bands. Samples: 1) MSCs cultured in 0,5\% FBS alone (control); 2) MSCs cultured in $0,5 \mathrm{mg} / \mathrm{mL}$ of conditioned medium from undamaged muscle; 3 ) MSCs cultured in $0,5 \mathrm{mg} / \mathrm{mL}$ of conditioned medium from LAMA2 $2^{\text {dy } / 2 j}$ dystrophic; 4) MSCs cultured in $0,5 \mathrm{mg} / \mathrm{mL}$ of conditioned medium from $m d x$ dystrophic muscle; 5) MSCs cultured in $0,5 \mathrm{mg} / \mathrm{mL}$ of conditioned medium from chemically damaged (CD) muscle; (C-G) Representative images of MSCs myogenic differentiation assessed by immunofluorescence using anti-human MyHC antibodies (red), after 15 days of incubation in culture medium containing $0,5 \%$ FBS alone (control) or supplemented with $0,5 \mathrm{mg} / \mathrm{mL}$ of conditioned medium prepared from undamaged muscle, LAMA $2^{d y / 2 j}$ and $m d x$ dystrophic muscle, and chemically damaged muscle (CD). Counterstaining with DAPI (blue) was used to identify all nuclei. Scale bar $=100 \mu \mathrm{m}$.

Figure 4: IGF-1 and TGF- $\beta$ levels determined by ELISA. (A,B) IGF-I and TGF- $\beta$ levels determined by ELISA in conditioned medium prepared from twomonth old undamaged $(n=7)$ muscle, LAMA2 ${ }^{d y / 2 j}(n=8)$ and $m d x \quad(n=11)$ dystrophic muscle and chemically damaged muscle $(n=12 ; C D)$. Data are presented as mean $\pm \mathrm{SE}$. ${ }^{*} \mathrm{P}<0.05$, versus undamaged muscle; one-way ANOVA; (C) IGF-1 levels in conditioned medium prepared from Tibialis Anterior (TA) muscles from $m d x$ and LAMA2 $2^{d y / 2}$ dystrophic mice of 1, 2 and 6 months of age. Data are presented as mean $\pm \mathrm{SE}$. ${ }^{*} \mathrm{P}<0.05$, versus one-month old muscle; one-way ANOVA. (D) Schematic representation of muscle repair, emphasizing the role of IGF-1 and TGF- $\beta$ in this process (Adapted from; Mourkioti and Rosenthal, 2005). Muscle damage disruptions capillaries and triggers the events of inflammation. Concomitantly with the muscle regeneration, the process of 
fibrosis is initiated - by the activation of TGF- $\beta$ - in order to replace the space within the broken myofibres with connective tissue. As the healing process continues the extent of fibrosis increases and, consequently, fills essential space in the muscle, which would otherwise be occupied by newly forming muscle cells. Therefore, the muscle regeneration is impaired, resulting in progressive muscle weakness. On the other hand, IGF-1 reduces the chronic inflammation and improves the muscle repair. Tissue regeneration depends on a precise balance between pro- and anti-inflammatory/fibrotic factors - including TGF- $\beta$ and IGF-1, respectively - that determine whether the damage is resolved or will induce scar formation. 
FIGURE 1

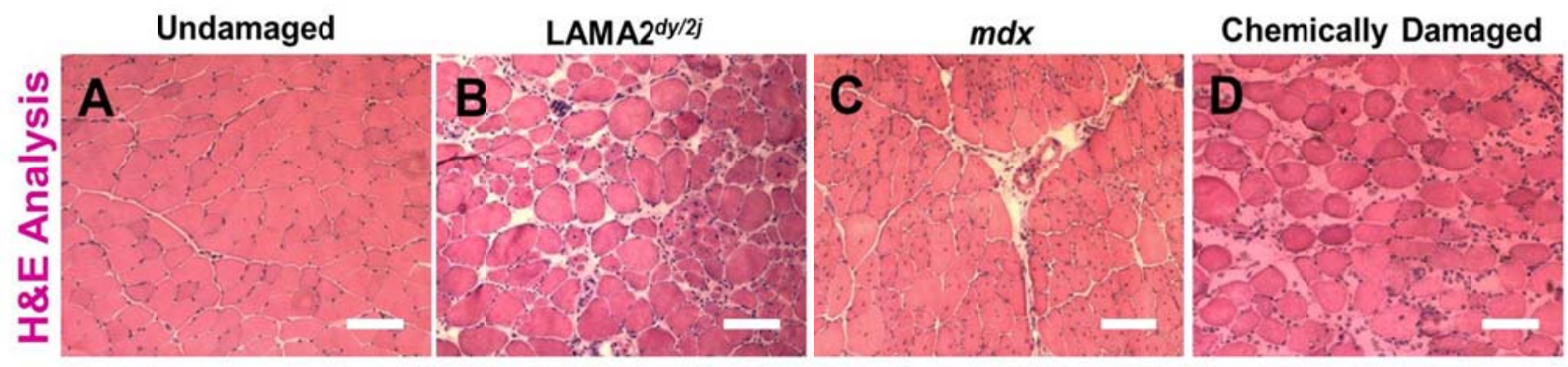

FIGURE 2

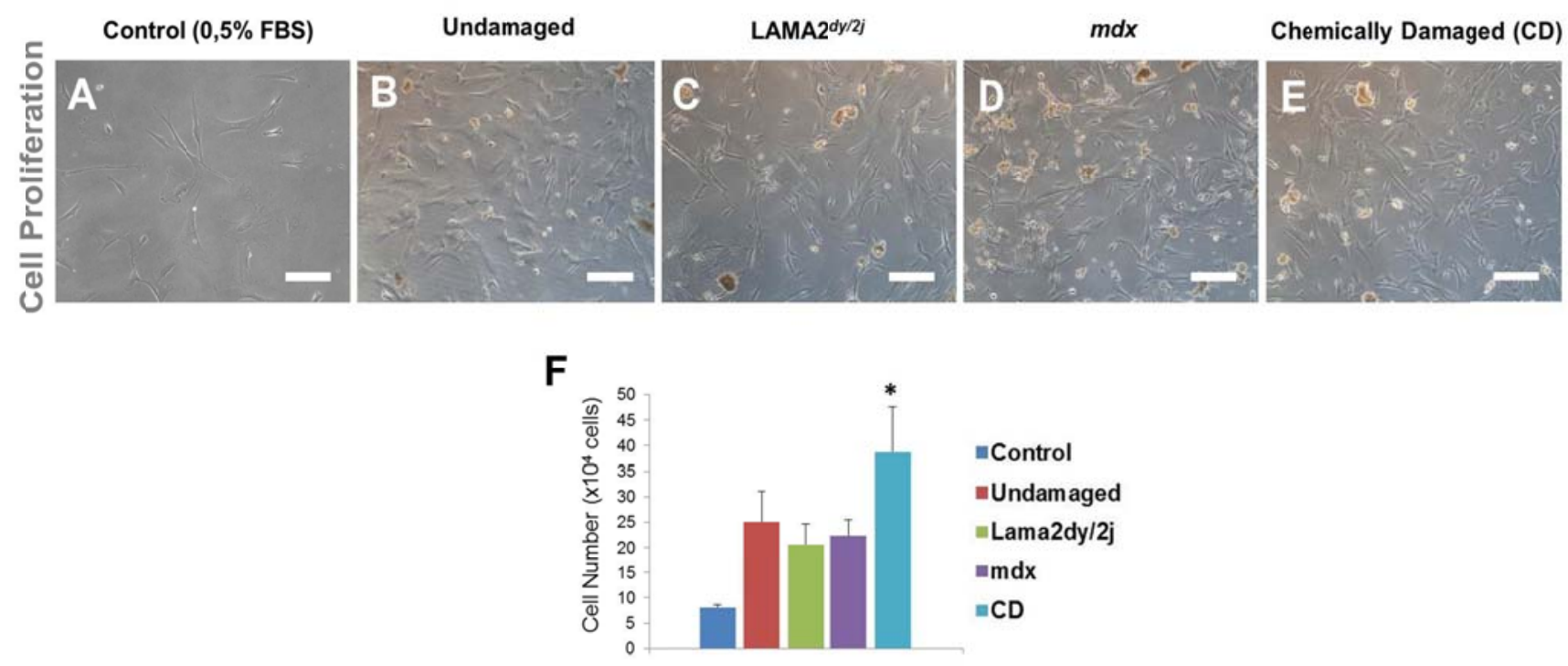




\section{FIGURE 3}
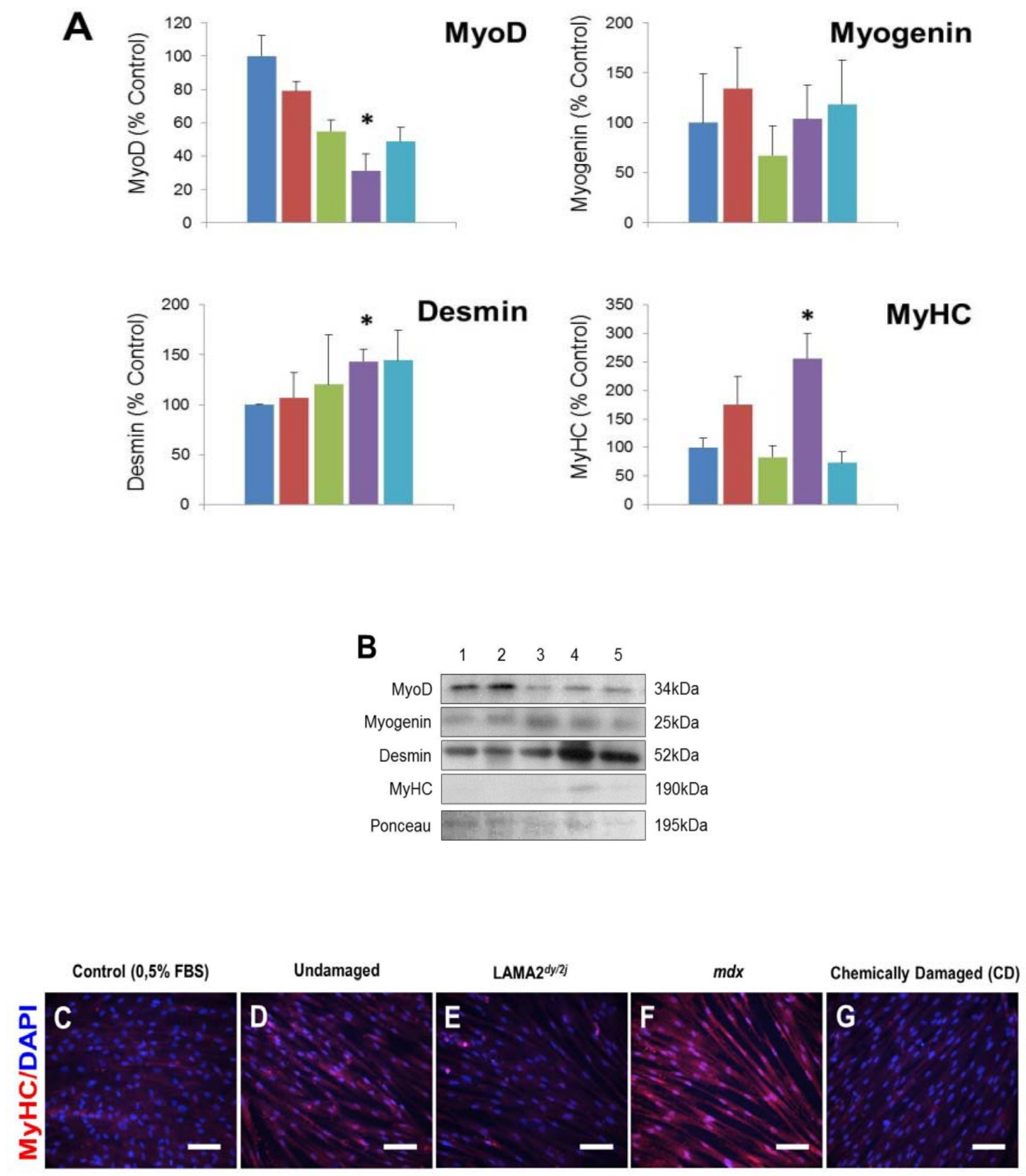


\section{FIGURE 4}
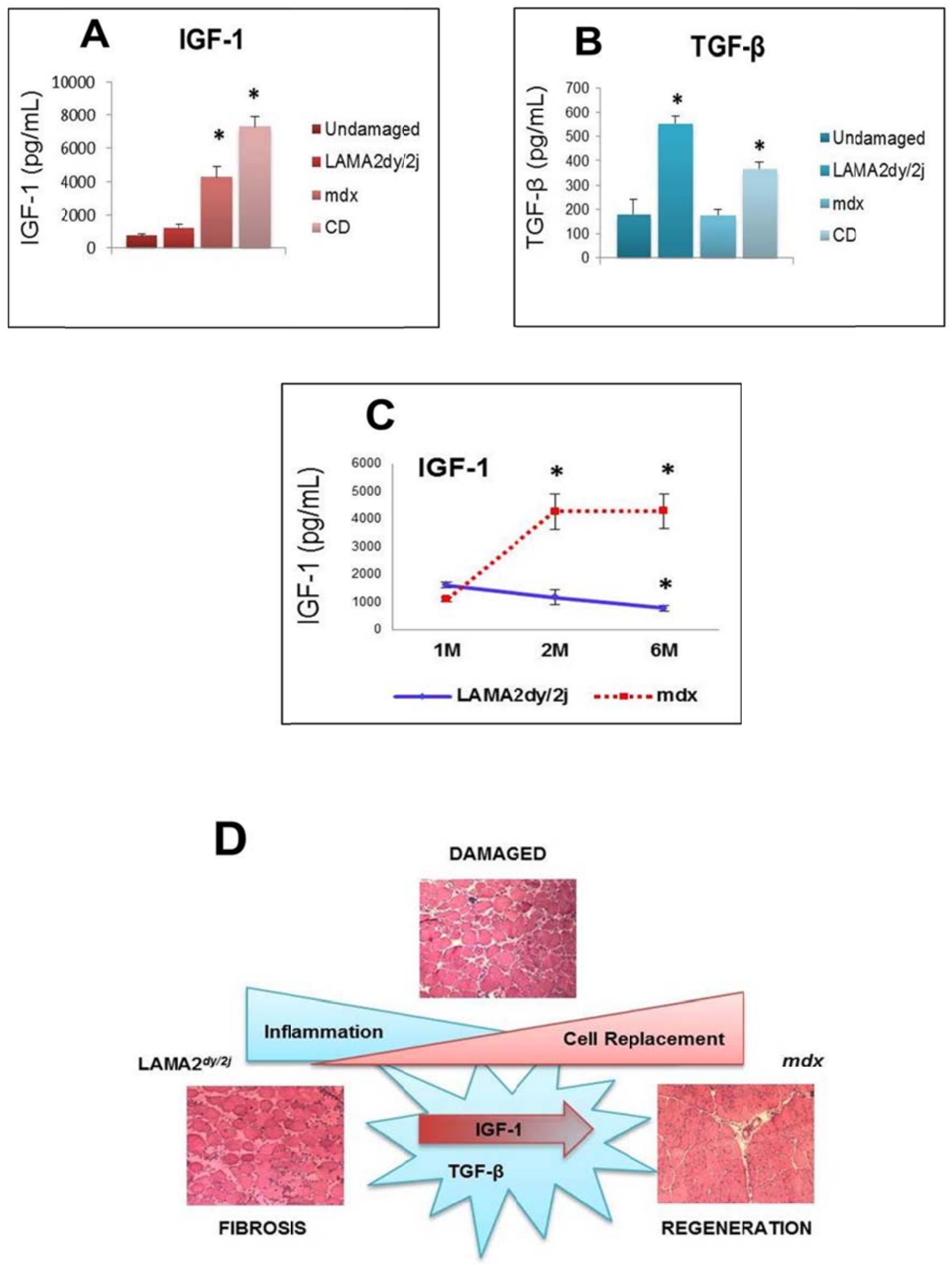

(Mourkioti and Rosenthal, 2005) 


\section{Capítulo 5}

POTENCIAL TERAPÊUTICO DE CÉLULAS-TRONCO MESENQUIMAIS DE CORDÃO UMBILICAL HUMANO ASSOCIADAS AO IGF-1 EM UM MODELO MURINO DE DISTROFIA MUSCULAR

Artigo submetido à Cell Stem Cells em Outubro de 2011

Systemic delivery of human mesenchymal stromal cells combined with IGF-1 enhances muscle functional recovery in a murine model of congenital muscular dystrophy.

Mariane Secco, Carlos Bueno Júnior, Natassia M. Vieira, Camila Almeida, Mayra Pelatti, Elen H. Miyabara, Mariz Vainzof, Oswaldo K. Okamoto, Mayana Zatz. 


\section{ABSTRACT}

Progressive muscular dystrophies are a heterogeneous group of disorders caused by the absence or deficiency of muscle proteins and characterized by progressive degeneration of skeletal muscle. Strategies for the development of a muscular dystrophy therapy have focused on the possibility of restoring the defective muscle protein by cell therapy or on delivery of growth factors to treat or ameliorate muscular pathology symptoms. Combining both strategies could be a very useful approach to enhance the efficiency of muscle repair. The main goal of the present study was to investigate the effects of insulin-like growth factor-1 (IGF-1) in the myogenic differentiation of human mesenchymal stromal cells (MSCs) from umbilical cord tissue (UC) in vitro and to assess the outcomes of the association of both IGF-1 and MSCs on muscle functional performance of the murine model for congenital muscular dystrophy type $1 \mathrm{~A}-\mathrm{LAMA}^{\text {dy/2j }}$. Therefore, 46 one-month old B6.WK-Lama2 ${ }^{\text {dy/2J }}$ dystrophic mice was assigned into four groups: untreated dystrophic group, IGF-1 treated group (2 mg/Kg/day for 8 weeks, via osmotic pumps), MSCs injected group $\left(1 \times 10^{6}\right.$ cells systemically injected, once a week for 2 months), and IGF-1+MSCs treated group. We demonstrated, for the first time, that IGF-1 is capable to enhance considerably the myogenesis of human MSCs from UC in vitro, through a stepwise progression similar to that which occurs during embryonic myogenesis. More interestingly, we showed that IGF-1 enhances the interaction of MSCs and DMD muscle cells in co-culture and the restoration of dystrophin expression. Our in vivo studies showed that MSCs were able to reach the skeletal muscle from LAMA $2^{d y / 2 j}$ mice but did not differentiate into muscle cells, even when associated with IGF-1. On the other hand, our data revealed that the association of IGF-1 
and MSCs markedly reduced muscle inflammation and fibrosis, and significantly improved muscle strength in muscular dystrophic mice. In summary, our results suggest that a combinatorial strategy of both IGF-1 and MSCs could enhance the efficiency of muscle repair and, therefore, should be further tested as a potential therapeutic approach in muscular dystrophies.

\section{RESUMO}

As Distrofias Musculares Progressivas constituem um grupo heterogêneo de doenças genéticas causadas pela deficiência ou ausência de proteínas musculares e caracterizadas pela degeneração progressiva da musculatura esquelética. As diferentes abordagens terapêuticas propostas para esse grupo de doenças têm como enfoque restaurar a proteína muscular deficiente por meio da terapia celular ou terapia gênica, ou o tratamento dos sinais e sintomas patológicos do músculo pela administração de fármacos e/ou fatores de crescimento. A combinação de diferentes estratégias pode aumentar a eficiência do reparo muscular. Com base nessa premissa, o principal objetivo deste estudo é investigar os efeitos do fator de crescimento semelhante à insulina (IGF-1; do inglês insulin-like growth factor) na diferenciação miogênica de células-tronco mesenquimais ou células estromais mesenquimais humanas (MSCs; do inglês mesenchymal stem cells) de tecido de cordão umbilical in vitro e avaliar o potencial terapêutico de MSCs, associadas ao IGF-1, em um modelo murino para a distrofia muscular congênita tipo 1A - LAMA2 ${ }^{d y / 2 j}$. Para isso, 46 camundongos LAMA2 $2^{d y / 2 j}$ foram randomicamente divididos em 4 grupos: grupo não tratado, grupo tratado com IGF-1 $(2 \mathrm{mg} / \mathrm{Kg} /$ dia por 8 semanas, via bombas

de infusão osmótica), grupo tratado com MSCs $\left(1 \times 10^{6}\right.$ células injetadas 
sistemicamente, 1 vez por semana por 2 meses), e grupo co-tratado IGF1+MSCs. Nós demonstramos, pela primeira vez, que o IGF-1 é capaz de aumentar significativamente a miogênese de MSCs humanas de cordão umbilical in vitro, em um processo que recapitula os eventos do desenvolvimento embrionário. Ainda nos estudos in vitro, nós mostramos que o IGF-1 aumenta a interação de MSCs com células musculares de pacientes DMD, quando em co-culturas, e restaura a expressão de distrofina. Os estudos in vivo mostraram que MSCs foram capazes de atingir o músculo esquelético dos camundongos LAMA2 $2^{d y / 2 j}$, mas não foram capazes de se diferenciar em células musculares in vivo, mesmo quando associadas ao IGF-1. Por outro lado, nosso dados indicam que as MSCs, em associação ao IGF-1, foram capazes de modular a inflamação, reduzir a fibrose, aumentar o reparo muscular e, consequentemente, promover uma melhora clínica significativa do músculo de camundongos LAMA2 ${ }^{d y / 2 j}$. Em suma, nossos resultados sugerem que a combinação de diferentes estratégias terapêuticas - IGF-1+MSCs - pode contribuir para aumentar a eficiência do reparo do músculo e, por essa razão, deve ser considerada como uma potencial abordagem terapêutica para as distrofias musculares. 


\title{
Systemic delivery of human mesenchymal stromal cells combined with IGF-1 enhances muscle functional recovery in a murine model of congenital muscular dystrophy
}

\author{
Mariane Secco ${ }^{1}$, Carlos Bueno Júnior ${ }^{1}$, Natassia M. Vieira ${ }^{1}$, Camila Almeida ${ }^{1}$, \\ Mayra Pelatti , Elen H. Miyabara ${ }^{2}$, Mariz Vainzok ${ }^{1}$, Oswaldo K. Okamoto ${ }^{1}$, \\ Mayana Zatz ${ }^{1 \dagger}$
}

1

Human Genome Research Center, Department of Genetic and Evolutive Biology, University of São Paulo, São Paulo, Brazil.

2

Department of Anatomy, Institute of Biomedical Sciences, University of São Paulo, São Paulo, Brazil.

\section{Keywords}

Human mesenchymal stromal cells, umbilical cord, IGF-1, muscular dystrophy therapy

Address correspondence to: Mayana Zatz, mayazatz@usp.br

Centro de Estudos do Genoma Humano, Departamento de Genética e Biologia Evolutiva, Universidade de São Paulo, São Paulo, SP, Brazil.

Rua do Matão, 106 - Cidade Universitária, 05508-090 São Paulo, SP, Brasil

Phone / fax number: (55) (11) 3091-7966

\section{Research support}

This work was supported by grants from CEPID-FAPESP (Centro de Pesquisa, Inovação e Difusão-Fundação de Amparo a Pesquisa do Estado de São Paulo), CNPq (Conselho Nacional de Desenvolvimento Científico e Tecnológico) and INCT (Instituto Nacional de Ciência e Tecnologia). 


\section{INTRODUCTION}

Progressive muscular dystrophies (PMDs) are a clinically and genetically heterogeneous group of disorders caused by the deficiency or abnormal muscular proteins and characterized by progressive degeneration and loss of skeletal muscle. Although the primary cause of disease, as well as specific signs and symptoms, vary among the different forms of muscular dystrophy, secondary events, including chronic inflammation, fibrosis and muscle regeneration failure, represent the final common pathway of virtually all chronic degenerative muscular dystrophies. These secondary events may also actively contribute toward the disease progression (Emery, 2002).

The most frequent and severe form of muscular dystrophy is Duchenne Muscular Dystrophy (DMD), a recessive lethal X-linked disease. The disease is caused by the absence of dystrophin, a critical component of the dystrophin-associated glycoprotein complex (DGC), which stabilizes the link of the muscle fiber cytoskeleton to the extracellular matrix (O'Brien \& Kunkel, 2001). Affected boys display progressive muscle weakness, resulting in loss of ambulation by age 12 and eventual death from cardiac or respiratory failure (O’Brien \& Kunkel, 2001).

Mutations in other DGC constituents result in numerous types of muscular dystrophies (Dalkilic and Kunkel, 2003; Petrof et al., 1993; Jones et al., 1998; Rando et al., 2001; Ehmsen et al., 2002). Among them, Laminin- $\alpha 2$ deficiencies result in a severe form of muscular dystrophy - Congenital Muscular Dystrophy type 1A (CMD1A) - the second most prevalent form of congenital muscular dystrophy. Affected patients present severe congenital hypotonia, 
extremely compromised neuromuscular function and muscle weakness that lead to the inability to achieve independent ambulatory capacity. Many children suffering from CMD1A succumb to premature death, also as a result of respiratory complications (Dubowitz, 1999; Dalkilic and Kunkel, 2003; Kumar et al., 2011).

Animal models manifesting phenotypes typical of specific human genetic disorders are important tools for understanding the disease pathogenesis and can be used as highly valuable resources to test new therapeutic approaches. The $m d x$ mouse (murine $X$-linked muscular dystrophy) is the most widely used animal model of DMD. Although it is a good genetic and biochemical model, this mouse is not very informative for pre-clinical trials due to its mild phenotype. On the other hand, the laminin- $\alpha 2$-deficient mouse model we used here - LAMA2 $2^{d y / 2 j}$ - develops severe muscle weakness at about 3 weeks of age, which progressively worsens. Histological analysis shows significant evidences of muscle degeneration, muscle fiber necrosis, increased fibrosis, and severe inflammation (Vainzof et al., 2008).

Despite several efforts aiming to enhance our understanding of the molecular basis of these groups of disorders, and that several promising experimental strategies are emerging (O'Brien \& Kunkel, 2001; Wells et al., 2003; Howard et al., 2004; Benchaouir et al., 2007; Chamberlain \& Chamberlain, 2010), currently there is no effective therapy for muscular dystrophies. Cellular therapies - involving the transplantation of stem cells or progenitors cells - have been the focus of worldwide investigation as candidates for regenerative treatment of a variety of diseases, including muscular dystrophies. Although most of the reported cell therapy studies in muscular 
dystrophies used cell populations isolated directly from muscle tissues, such as satellite cells and mesoangioblasts (Sampaolesi et al., 2006; Rouger et al., 2011), other identified sources of stem cells have also shown the ability to generate normal muscle fibers in vitro and in vivo. In particular, mesenchymal stem cells or mesenchymal stromal cells (MSCs), a population of adult stem cells obtained from different tissues, have been extensively investigated in various pre-clinical studies involving animal models of muscular dystrophy (Kerkis et al., 2008; Vieira et al., 2008; Gang et al., 2009; Vieira et al., 2010; Vieira et al., 2011; Nitahara-Kasahara et al., 2011; da Justa Pinheiro et al., 2011). We demonstrated recently that MSCs obtained from human adipose tissue are able to migrate from the circulation into dystrophic muscles, express a significant amount of human muscle proteins and improve motor ability of murine and canine models of muscular dystrophies when injected systemically without immunosuppression (Vieira et al., 2008; Vieira et al., 2011). Other abundant and accessible source of MSCs is umbilical cord (UC) tissue. The ability of human MSCs from UC to differentiate into skeletal muscle was also demonstrated by us in vitro (Secco et al., 2008a,b). On the other hand, more recently we showed that MSCs from UC, when systemically injected in a dystrophic mouse, are able to reach the skeletal muscle but did not differentiate into muscle cells (Vieira et al., 2010; Zucconi et al., 2011). In fact, most recent studies have reported discrepant results about MSCs differentiation after delivery into skeletal muscle. Therefore, several works have tried to improve the myogenic potential of MSCs, by the forced expression of key regulators of the myogenic program (Gang et al., 2008; Gang et al., 2009; Wagner et al., 2009; Goudenege et al., 2009; Kocaefe et al., 2010; Nitahara-Kasahara et al., 2011). 
Other limitations also remained to be resolved to improve the success of MSCs clinical application. One of them is the early cell death following stem cell injection. The chronic inflammation observed in dystrophic muscle could explain part of this observed cell death. Furthermore, fibrotic tissue inevitably forms a barrier to muscle cell repopulation. Taking into account these difficulties, recent studies have attempted to optimize MSC-based therapeutics, by either enhancing their survival, potency or increasing their engraftment to target tissues. Combining both MSCs transplantation and administration of potency-enhancing factors is an approach that could be interesting for these purposes (Wagner et al., 2009).

Insulin-like growth factor-1 (IGF-1) is known to improve muscle regeneration, by enhancing proliferation, differentiation, and survival of progenitor muscle cells (Mourkioti and Rosenthal, 2005). IGF-1 administration or muscle-specific overexpression have contributed to maintain regeneration efficacy and to reduce muscle pathology in dystrophic mice, by modulating the inflammatory response and reducing fibrosis (Barton et al., 2002; Gehrig et al., 2008; Kumar et al., 2011). In addition, several evidences indicate that IGF-1 can enhance the recruitment of muscle progenitor cells to the site of injury during muscle regeneration and, therefore, improve the cell transplantation success (Sacco et al., 2005; Pelosi et al., 2007; Mills et al., 2007; Kumar et al., 2011). However, the effects of IGF-1 in MSCs transplantation in muscular dystrophy animal models were not described yet. Although IGF-1 proprieties are very useful to muscle repair, it is important to point out that overexpression of IGF-1 alone is unable to restore mechanical integrity of muscle fibers lacking muscle 
proteins and therefore is incapable of preventing the degeneration of dystrophic muscle fibers.

Altogether, these previous reports led us to investigate, for the first time, whether IGF-1 is able to promote the myogenic differentiation of MSC from UC in vitro, and if the association of both IGF-1 and human MSCs from UC could improve functional performance when administrated in a murine model for congenital muscular dystrophy type $1 \mathrm{~A}-\mathrm{LAMA}^{d y / 2 j}$.

\section{MATERIAL AND METHODS}

All experiments were approved by the research ethics committee of the Biosciences Institute, University of São Paulo. All human tissue samples were obtained after written informed consent of the donors. In vivo studies were conducted in accordance with the ethical principles in animal research adopted by the Brazilian College of Animal Experimentation (www.cobea.org.br) and were approved by the University of São Paulo, Institute of Biosciences Ethical Committee.

\section{Isolation and Culture of Adherent Cells from UC}

Human umbilical cord tissue was obtained and processed using methods previously described (Secco et al., 2008, 2009). Briefly, sections of 8$10 \mathrm{~cm}$ of umbilical cords were internally washed with phosphate-buffered saline (PBS), supplemented with 3\% penicillin/streptomycin (Invitrogen-Gibco, Grand Island, NY, http://www.invitrogen.com) and immediately immersed in Dulbecco's 
modified Eagle's medium-low glucose (DMEM-LG; Invitrogen-Gibco) supplemented with $10 \%$ fetal bovine serum (FBS; Invitrogen-Gibco) and 3\% penicillin/streptomycin (Invitrogen-Gibco). UCs were filled with 0,1\% collagenase (Sigma-Aldrich, St. Louis, http://www.sigmaaldrich.com/sigmaaldrich/home.html) in PBS and incubated at $37^{\circ} \mathrm{C}$ for $15-20$ minutes. Each UC was washed with proliferation medium (DMEM-LG supplemented with $10 \%$ FBS and $1 \%$ penicillin/streptomycin), and the detached cells were harvested after gentle massage of the UC. Cells were centrifuged at $300 \mathrm{~g}$ for 10 minutes, resuspended in proliferation medium (PM), and seeded in $25-\mathrm{cm}^{2}$ flasks at a density of $5 \times 10^{7}$ cells per $\mathrm{mL}$. After 24 hours of incubation, non-adherent cells were removed, and PM was replaced every 3 days. Cultures were passaged repeatedly until passage 4 , when we started the experiments. The remaining cells were cryopreserved in cryopreservation media $(10 \%$ dimethylsulfoxide, $90 \%$ FBS), frozen at $-80^{\circ} \mathrm{C}$ in isopropanol-jacked closed container and stored in liquid nitrogen the next day.

\section{Characterization of Adherent Cells from UC}

To analyze cell-surface expression of typical protein markers, adherent cells were incubated with the following anti-human primary antibodies: CD29-PECy5, CD34-PerCP, CD31-phycoerythrin (PE), CD45-fluorescein isothiocyanate (FITC), CD90-R-PE, CD73-PE, CD13-PE, CD44-PE, CD117-PE, human leukocyte antigen (HLA)-ABC-FITC, HLA-DR-R-PE (Becton, Dickinson and Company, Franklin Lakes, NJ, http://www.bd.com). A total of 10,000 labeled cells were analyzed using a Guava EasyCyte flow cytometer running Guava 
ExpressPlus software (Guava Technologies Hayward, CA, http:// www.guavatechnologies.com). To evaluate MSCs properties, adherent cells (third passage, at $80 \%-90 \%$ confluence) were subjected to adipogenic, chondrogenic, and osteogenic differentiation in vitro, according to established protocols (Secco et al., 2008).

\section{Myogenic Differentiation Assay In Vitro}

To induce myogenic differentiation, MSCs were incubated in differentiation medium - DMEM-High Glucose (DMEM-HG), supplemented with $3 \%$ Horse Serum (HS) and 1\% penicillin/streptomycin - for 15 days, according to protocols previously established (Secco et al., 2008; Vieira et al., 2008a).

To evaluate and compare the effect of IGF-1 on the myogenic differentiation of MSCs, approximately $2 \times 10^{5}$ cells were plated in 6 -wells plates (Costar, Corning) and incubated in differentiation medium enriched or not with IGF-1 (Long R3-IGF-1; Sigma-Aldrich) at different concentrations, as indicated in the respective figures. At each time interval, the expression of selected myogenic markers was analyzed by Real Time RT-PCR, Western Blot and Immunofluorescence, as described below.

\section{Co-culture Experiments}

For the co-culture experiments we used DMD muscle cells from primary cultures obtained from muscle biopsies taken for diagnostic purposes in the Human Genome Research Center, following informed consent. Normal 
skeletal muscle was obtained from healthy DMD fathers. The biopsies were processed according to protocol 11.4 described in Freshney, 2000.

The myoblasts were cultured in PM for muscle cells - DMEM-HG supplemented with $20 \%$ FBS and $1 \%$ penicillin/streptomycin. Cells were maintained at $37^{\circ} \mathrm{C}$ and $5 \% \quad \mathrm{CO}_{2}$. To differentiate human myoblasts into myotubes, the cells were rinsed twice with PBS and cultured in DM for 1 week.

The identification of MSCs from UC in the co-cultures with myoblasts was done by transfection with lentiviral vectors expressing GFP, produced as described previously (Vieira et al., 2008a).

Two different types of co-cultures were tested. In the first we mixed equal amounts of myoblasts stained with DAPI (4'-6-Diamidino-2-phenylindole; Sigma-Aldrich) and GFP-positive MSCs from UC plated at 90\% confluence on culture dishes in differentiation medium supplemented or not with $50 \mathrm{ng} / \mathrm{mL}$ IGF1. In the second, DMD myotubes stained with DAPI were co-cultured with GFPpositive MSCs from UC at a ratio of 3:1 of plated myotubes and MSCs, and the co-cultures were maintained in proliferation medium supplemented or not with $50 \mathrm{ng} / \mathrm{mL}$ IGF-1. Culture medium was replaced every 2-3 days. After 45 days, cells were observed through direct fluorescence microscopy to confirm if there was interaction between the MSCs and DMD muscle cells, by the presence of DAPI/GFP ${ }^{+}$myotubes. Dystrophin expression was analyzed by Western Blot, as described below.

Co-culture control experiments were: GFP-positive MSCs from UC maintained undifferentiated; GFP-positive MSCs from UC maintained in DM; normal control myoblasts co-cultured with GFP-positive MSCs from UC; DMD 
myoblasts. The myoblast controls were exposed to DM supplemented or not with $50 \mathrm{ng} / \mathrm{mL}$ IGF-1, as the co-culture experiments described above.

\section{In Vivo Experimental Design}

A cohort of 46 one-month old B6.WK-Lama2 ${ }^{d y / 2 J}$ dystrophic mice (Jackson Laboratory) was randomly assigned into four experimental groups: untreated group (U; n=11), IGF-1-treated group (IGF-1;n=9), MSCs group (MSC; n=13), and group treated with both IGF-1 and MSC (IGF-1+MSC; n=13). Age-matched B6.WK non-dystrophic mice were used as wild-type controls (CNT; $n=21)$. PCR assays on tail DNA were performed to genotype the animals, in order to delineate between LAMA2 ${ }^{d y / 2 j}$ dystrophic mice, heterozygous for the LAMA2 gene mutation and B6.WK non-dystrophic mice.

The analog recombinant human IGF-1 (Long R3-IGF-1; SigmaAldrich) was administered via a subcutaneously implanted osmotic mini-pump (model 1002; Alzet, Cupertino, CA) at a daily dose of $2 \mathrm{mg} / \mathrm{kg}$ body mass, for a period of 8 weeks. The untreated and MSCs group received the vehicle solution (100 mM acid acetic) via the same osmotic pump as a control for the administration method. Mice were anesthetized with pentobarbitone sodium (Nembutal, 40 mg/kg i.p.; Rhone Merieux, Pinkenba, QLD, Australia) such that they were unresponsive to tactile stimuli. The surgical site was shaved and a small right paravertebral incision was made on the dorsal surface between the hind limbs. Connective tissue below the skin was blunt dissected to create a pouch for placement of the pump. The loaded osmotic pump (IGF-1 or vehicle solution) was inserted into this cleft with the pumping end orientated caudally. The small skin incision was closed with nonabsorbable sutures and swabbed 
with povidone iodine solution. Since the mini-osmotic pumps deliver continuously for 14 days, the 8-week administration period required each animal to have a new pump (with identical IGF-I or saline solution) implanted every 2 weeks of continuous treatment. During 2 months, weekly, $1 \times 10^{6}$ MSCs were systemically injected in the tail vein of the animals from the MSCs and IGF1+MSCs groups.

\section{Functional Analysis}

At the end of the 8-week treatment, animals were submitted to muscle functional tests. In order to evaluate the grip force, animals were allowed to grab onto the Grip Strength System (model: DFE-002, San Diego Instruments, San Diego, Cal, USA) with both hind paws which measures the maximal force before the animal releases the paws of the bar.

For the measurement of contractile properties, mice were anesthetized with pentobarbitone sodium (Nembutal, $40 \mathrm{mg} / \mathrm{kg}$; Rhone Merieux, Pinkenba, QLD, Australia) with supplemental doses administered to maintain a depth of anesthesia that prevented all responses to tactile stimuli. In brief, Tibialis Anterior (TA) muscles from animal models were stimulated by supramaximal $(10 \mathrm{~V}) 0.2-\mathrm{ms}$ square wave pulses of $500 \mathrm{~ms}$ in duration at $2 \mathrm{~Hz}$, delivered via two wire electrodes adjacent to the sciatic nerve. For determination of tetanic force, the frequency of electrical stimulus was elevated to $250 \mathrm{~Hz}$. The muscle twitch force (peak of muscle twitch force) and tetanic force (peak of tetanus) were recorded using the Biopac Systems. The muscle strength was analyzed using the AcqKnowledge 3.9.1.6. Twitch and Tetanic Forces were normalized to body mass. 
After completion of all surgical procedures, the mice were killed by cervical dislocation. The muscles were then excised, weight and prepared for molecular, biochemical, and histological analysis. Blood samples were also harvested for glucose, triglycerides and cholesterol analysis, as recommended by the manufacturer (Labtest, Lagoa Santa, MG, Brazil).

\section{Human DNA analysis}

The presence of human DNA in the host samples was evaluated as described in Pelz et al., 2005. Human chromosome 7 a-satellite sequence (H7) was amplified by PCR (35 cycles, annealing at $59^{\circ} \mathrm{C}$ ). The PCR products were separated by electrophoresis on $6 \%$ acrylamide gels and stained with ethidium bromide. Non-saturated digital images were obtained using an Image Quant Imaging System (GE HealthCare). The primers sequences are listed in

\section{TABLE 1.}

\section{Muscle Histopathology}

Muscles prepared for histological analysis were immediately frozen in melting isopentane and stored in liquid nitrogen. The frozen muscles were cut into $10 \mu \mathrm{m}$ cross sections from the proximal to distal region using a cryostat (Criostat Mícron HM505E, Walldorf, Germany). Sections of muscle were then stained with Hematoxylin and Eosin (H\&E) as previously described (Dubowitz, 1985). Muscle cross sections were evaluated at 200x magnification and further analyzed on a digitizing unit connected to a computer (Image Pro-plus, Media Cybernetic, Silver Spring, MD, USA). The cross-sectional areas (CSA), 
percentage of fibers with centronuclei and interstitium extent in the muscle were analyzed in blind test.

\section{Real-Time Quantitative RT-PCR}

Total RNA was extracted from cultured cells (in vitro studies) or mouse muscle samples (in vivo studies) using TRIzol reagent (Invitrogen) as recommended by the manufacturer. First strand cDNA was produced from $1 \mu \mathrm{g}$ of RNA using Superscript III reverse transcription kit (Invitrogen). Real-time Quantitative RT-PCR was performed with $50 \mathrm{ng}$ of cDNA and SYBR Green PCR master mix (Applied Biosystems) in an 7500 Real-Time PCR System (Applied Biosystems). The PCR conditions were: $94^{\circ} \mathrm{C}$ for $15 \mathrm{~s}, 58^{\circ} \mathrm{C}$ for $30 \mathrm{~s}$, and $72^{\circ} \mathrm{C}$ for $30 \mathrm{~s}$ for 40 cycles. The authenticity of the PCR products was verified by meltcurve analysis. The primers sequences are listed in TABLE 1. Samples were run in triplicates, and the threshold suggested by the instrument software was used to calculate $\mathrm{Ct}$. To normalize the readings we used $\mathrm{Ct}$ values from the GAPDH. The data are reported as a ratio of absolute mRNA copy number of each specific gene to the absolute copy number of GAPDH.

\section{Western Blot Analysis}

Cell (in vitro studies) or muscle (in vivo studies) proteins were extracted through treatment with a buffer containing $10 \mathrm{mM}$ Tris- $\mathrm{HCl}(\mathrm{pH} 8.0)$, 150mM NaCl, 5mM EDTA, 1\% Triton X-100 and 60mM octyl glucoside. Samples were centrifuged at $13,000 \times \mathrm{g}$ for 10 minutes to remove insoluble debris. 
Soluble proteins were resolved by sodium dodecyl sulfate-polyacrylamide gel electrophoresis (SDS-PAGE), and transferred to nitrocellulose membranes (Hybond; Amersham). Equal loading of samples (50 $\mu \mathrm{g})$ and transfer efficiency were monitored using $0.5 \%$ Ponceau $S$ staining of the blotted membrane. Blots were blocked for 1 hour in Tris-buffered saline Tween (TBST) containing 5\% powdered skim milk and reacted overnight with the following primary antibodies: rabbit monoclonal anti-Pax $7(0,1 \mathrm{ug} / \mathrm{mL}$; Lifespan Bioscience), mouse monoclonal anti-MyoD $(2 \mu \mathrm{g} / \mathrm{mL}$; Becton Dickinson), mouse monoclonal antimyogenin (1:200; Abcam), rabbit anti-desmin (1:100; Sigma-Aldrich); mouse monoclonal anti-dystrophin MANDYS 104 (1:500; kindly provided by Dr. Glenn E. Morris at Center for Inherited Neuromuscular Diseases, Oswestry,

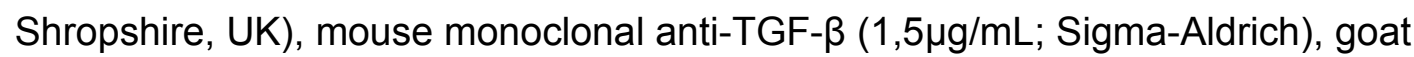
polyclonal anti-TNF-a (1:200; Santa Cruz Biotechnology), goat polyclonal antiMURF1 (1:1000; Santa Cruz Biotechnology), rabbit polyclonal anti-calpain1 (1:1000; Cell Signaling), rabbit polyclonal anti-calpain 2 (1:1000; Cell Signaling), rabbit polyclonal anti-calpastatin (1:1000; Abcam); mouse monoclonal anti-NCX (1:1000; ABR Incorporation) and mouse monoclonal anti-SERCA1 (1:1000, ABR Incorporation). Blots were incubated one hour with secondary antibodies (horseradish peroxidase-conjugated antibody) and immunoreactive bands were detected with ECL chemiluminescence detection system (GE Healthcare). Quantitative analysis of human dystrophin at the host muscle was performed by using the ImageJ software (http://rsb.info.nih.gov/ij/), considering the Myosin at the Ponceau staining as a load protein control. 


\section{Immunofluorescence}

Cells grown in a 1-chamber slides (Nalgene-NUNC) were fixed in $4 \%$ paraformaldehyde in PBS for $20 \mathrm{~min}$ at $4^{\circ} \mathrm{C}$ and permeabilized in $0,05 \%$ Triton X-100 in PBS for 5 minutes. Non-specific binding was blocked with $10 \%$ FBS in PBS for 1 hour at room temperature. Cells were incubated with primary antibody overnight at $4^{\circ} \mathrm{C}$ and with secondary antibody for 1 hour at room temperature. The following primary antibodies were used: Anti-Desmin (1:20, Sigma-Aldrich), Anti- Skeletal Myosin (1:20, Sigma), combined with goat antirabbit IgG secondary antibody, Cy3-Conjugated (1:100, Chemicon). The fluorescence signal was examined in Axiovert 200 (Carl Zeiss) and in ApoTome Imaging System (Carl Zeiss).

\section{Statistical Analysis}

All values are presented as means \pm standard error (SE). Student's $t$ test and one-way ANOVA followed by Tukey's posttest were used to compare the groups. Statistical significance was considered as $p<0.05$.

\section{RESULTS}

IGF-1 enhances the myogenic differentiation of MSCs. Adherent cells from UC were previously characterized (Secco et al., 2008). The evaluation of MSCs properties included immunophenotyping by flow cytometric analysis, using a panel of surface markers. At passage four, adherent cells from UC were 
negative for CD31 (endothelial cell marker), CD34, CD45, CD117 (hematopoietic cell markers), and HLA-DR (human leukocyte differentiation antigen class II), whereas they were positive for CD29, CD44, CD90, (adhesion markers) CD73, CD13 (mesenchymal markers), and HLA-ABC (human leukocyte differentiation antigen class I; data not shown). The cell plasticity was assessed by in vitro differentiation capacity, after three weeks of induction using appropriate conditions. Adipogenic, chondrogenic and osteogenic differentiation was demonstrated by the presence of lipid vacuoles, mucopolysaccharide-rich extracellular matrix and calcium deposits, respectively (data not shown). These results confirmed the mesenchymal nature of the isolated cells as well as their multipotent potential.

In order to verify if IGF-1 is capable of promoting a more efficient myogenesis of MSCs than the usual protocols, the cells were incubated in DM supplemented with different concentrations of IGF-1. Prior to myogenic induction (Control), MSCs from UC were negative or expressed low levels of muscle lineage markers, as measured by immunofluorescence and western blot analysis (FIGURE 1 A,B). Continuous exposure of MSCs from UC to DM (HS) supplemented or not with IGF-1 over 15 days resulted in the development of multinucleated Desmin and MyHC-positive fibers on immunofluorescence staining (FIGURE 1B). However, myogenic differentiation was more prominent in MSCs cultured with DM containing IGF-1 than those cells cultured only in DM, as shown by Western Blot analysis which revealed up-regulation of earlier myogenic markers, such as Pax7, MyoD and Myogenin, as well as markers of 
terminal muscle differentiation, including, MyHC, Desmin and Dystrophin (FIGURE 1A).

Finally, a time course examination of myogenic markers by western blot analysis revealed a gradual increase in Pax-7 expression in MSCs subjected to myogenic differentiation. In contrast to non-induced cells, MSCs exposed to $50 \mathrm{ng} / \mathrm{mL}$ IGF-1 showed an increase of approximately 4 and 16 -fold in the expression of Pax-7 at 8 and 15 days, respectively. The expression of MyoD and Myogenin also increased sequentially; 16 and 34-fold in the MyoD expression, 4 and 6-fold in the Myogenin levels in MSC treated with 50ng/mL for 8 and 15 days, respectively. In a similar manner, the expression of later myogenic markers also increased over time in MSCs treated with IGF-1. When compared with non-induced cells, MSCs exposed to $50 \mathrm{ng} / \mathrm{mL}$ IGF-1 showed about 5- and 13-fold increased expression of Desmin, as well as Dystrophin, at 8 and 15 days, respectively (FIGURE 1A).

These results were confirmed by Real-Time Quantitative RT-PCR that showed a significantly increase in MyHC expression only in MSCs treated with $25 \mathrm{ng} / \mathrm{mL}$ IGF-1 for 15 days, in comparison with MSCs treated with DM alone (FIGURE 1C).

IGF-1 enhances the interaction between MSCs and DMD muscle cells and restores dystrophin expression. MSCs expressing GFP were co-cultured with primary GFP-negative DMD myoblasts or myotubes previously stained with DAPI. The FIGURE 2A shows a schematic representation of the co-culture experiments. The MSCs from UC were stably transfected with GFP in order to 
distinguish them from DMD myoblasts. About $80-90 \%$ of cells were GFP-positive and GFP expression did not decline during culture passages (FIGURE 2B). In addition, we demonstrated previously that GFP transduction did not influence the multilineage potential of human MSCs (Lin et al., 2006). The co-culture of DMD myoblasts and MSCs was exposed to DM supplemented or not with IGF-1 to induce myoblasts to coalesce and form multinucleated structures.

After 45 days, multinucleated myotubes were observed with areas of GFP-positive syncytia in the resulting cultures (data not shown). These results indicate that GFP-positive MSCs were able to interact with DMD myoblasts. To evaluate whether MSCs from UC contributed to the pool of human myotubes by differentiation, fusion, or both, co-cultures were kept under myogenic differentiation conditions and visualized through direct fluorescence microscopy analysis. Only in co-cultures treated with IGF-1, we observed GFPpositive syncytia presenting at least one DAPI stained nucleus. Similarly, in the co-culture of DMD myotubes and MSCs maintained in proliferation medium supplemented with IGF-1, we showed GFP-positive myotubes containing DAPI stained nuclei (FIGURE 2B). Therefore, we could conclude that MSCs from UC participate in the generation of human myotubes through cellular fusion, and that IGF-1 contributes actively to this process.

Finally, we analyzed the dystrophin protein levels in the two different co-cultivation assays. As expected, there was no dystrophin expression in DMD muscle cell culture. In contrast, as seen in FIGURE 2C, dystrophin expression was restored in DMD muscle cells co-cultured with MSCs. More interestingly, IGF-1 treatment induced a robust increase in the levels of 
dystrophin protein in both $\mathrm{DMD} /$ normal myoblast and myotubes co-cultures (FIGURE 2C).

IGF-1 and MSCs treatment do not alter basic parameters of LAMA2/y2j injected mice. As presented in the TABLE 2, continuous administration of IGF1 protein for 8 weeks, MSCs injections or both treatments combined did not alter morphometric properties such as body, heart, liver and Tibialis Anterior (TA) mass as well as the triglycerides values in comparison to untreated dystrophic LAMA2 ${ }^{d y / 2 j}$ mice. Although we observed an increase in the glucose levels of the dystrophic mice from the treated-groups, similar to those observed in control mice, these values did not reach a statistical significance. Only the levels of cholesterol were significantly decreased in the group that received both IGF-1 and MSC, when compared to the values of the untreated dystrophic group (TABLE 2).

\section{Association of IGF-1 and MSCs improves skeletal muscular strength in} LAMA2 $^{\text {dy/2j }}$ dystrophic mice. To verify the effects of the associated treatment on disease progression, we compared the grip force of each LAMA2 $2^{d y / 2 j}$ mouse before and after treatment. As shown in FIGURE 3A, untreated dystrophic mice presented a significant decrease of $43 \pm 12 \%$ in their grip force, measured 2 months after the experiment onset. Although mice treated with either IGF-1 or MSC individually showed a delay in disease progression compared with the untreated dystrophic mice, they also worsened significantly their performance in about $23 \pm 8 \%$ and $25 \pm 12 \%$, respectively (FIGURE $3 A$ ). Only the group of mice treated with both IGF-1 and MSCs presented a significant improvement of 
$12 \pm 9 \%$ in grip force when evaluated two months post-treatment, in comparison with untreated, IGF-1 and MSCs group (FIGURE 3A). IGF-1+MSC group also presented a significant increase in both muscle twitch and tetanic force, similar to those observed in control muscle (FIGURE 3B,C).

We also assessed the LAMA2 ${ }^{d y / 2 j}$ dystrophic mice performance in rotarod, ambulation and running tests, before and after treatment. However, there were no statistical differences among groups (data not shown).

Altogether, these results indicate that only the combination of both IGF-1 and MSCs restored skeletal muscle strength in dystrophic mice.

MSCs from UC injected systemically in LAMA2 ${ }^{d y / 2 j}$ dystrophic mice were able to reach the skeletal muscle but did not differentiate into muscle cells, even when associated with IGF-1. IGF-1 is considered an important modulator of several cellular processes, such as proliferation, differentiation, survival and migration (Mourkioti and Rosenthal, 2005). In order to verify if IGF1 could contribute to survival and muscle engraftment of MSCs systemically injected in dystrophic mice, we performed a PCR using specific primers to human DNA. As observed in FIGURE 4A, human DNA was found in TA muscle of both MSCs injected mice and IGF-1+MSCs-treated mice. According to our previous in vitro results, IGF-1 increased myogenic differentiation of MSCs. To verify whether the improvement in muscular strength observed in the IGF1/MSC group could be associated with an enhanced myogenesis from injected MSCs, we analyzed the expression of human muscle proteins. However, no human dystrophin was found in the muscles of the MSCs injected animals through western-blot analysis (IGF-1+MSC and MSC groups; FIGURE 4B). We 
also confirmed these results with Real-time Quantitative RT-PCR using specific human primers to dystrophin, which showed no transcript expression (data not shown). These results suggest that MSCs from UC - differently from results obtained from in vitro experiments - were not able to differentiate into muscle cells in vivo. These findings reinforce the importance of pre-clinical studies to confirm the results obtained in vitro.

\section{Association of both MSCs and IGF-1 reduces fibrosis in LAMA2 $^{\text {dy/2j }}$} dystrophic muscle. To better understand the effects of both IGF-1 and MSCs in dystrophic muscle, we stained muscle sections with hematoxylin and eosin (H\&E) and analyzed the morphological characteristics of LAMA2 ${ }^{d y / 2 j}$ pathology (FIGURE 5A). As expected, H\&E staining of untreated dystrophic TA muscle showed typical features of muscular dystrophy, including abnormal variation of fiber size, central nucleation and excessive interstitial fibrosis, when compared with control muscle (FIGURE 5A,B). Moreover, detailed morphological analysis of random fields of muscle cross sections demonstrated that the TA muscle median CSA was $\sim 40 \%$ lower in untreated LAMA2 ${ }^{d y / 2 j}$ mice as compared with control muscles $(P<0.05)$. The administration of IGF-1, MSC or IGF-1+MSC did not alter significantly the fiber CSA in the TA muscles compared with the untreated group. Although not significant, there was a decrease in the mean percentage of central nucleation in IGF-1 and IGF-1+MSC-treated mice when compared with the untreated group (FIGURE 5A,B). In contrast, MSCs treatedgroup revealed an increase in the number of centronucleated fibers in TA muscle relative to untreated LAMA $2^{d y / 2 j}$ mice (FIGURE 5B). Finally, we analyzed the amount of interstitium in the TA muscles of untreated and treated groups. 
Although the IGF-1 group presented a moderate reduction in the interstitium, only the group of mice treated with IGF-1+MSC showed a significant decrease in the interstitium extent. Muscles of MSC-treated mice, on the other hand, showed an average amount of interstitium similar to LAMA2 ${ }^{d y / 2 j}$ untreated muscles (FIGURE 5B). To verify if the amount of interstitium was related with the extent of fibrosis in LAMA $2^{d y / 2 j}$ mice, we performed a picro-sirius red staining (FIGURE 5A). Only mice treated with IGF-1+MSC had a significant reduction in the extent of fibrosis, measured by percent of picro-sirius red staining, when compared with the untreated dystrophic group (FIGURE 5B). This result suggests that only the association of IGF-1 and MSCs reduces the fibrosis in dystrophic muscle.

In addition to picro-sirius analysis, we examined the expression patterns of specific proteins related with the fibrous tissue formation, including type I (Col1a1) and III (Col3a1) fibrillar collagens and transforming growth factor beta 1 (TGF- $\beta 1$; FIGURE 5C,D) . Western blot analysis revealed that the expression of TGF- $\beta$ protein was prominently down-regulated in the group treated with IGF-1+MSC in comparison with the untreated group. On the other hand, administration of IGF-1 or MSCs individually did not alter TGF- $\beta$ protein expression (FIGURE 5D). We also confirmed these results with Real-time Quantitative RT-PCR analysis, which showed that only the IGF-1+MSC group presented a significantly reduction in TGF- $\beta$ expression (FIGURE 5C). Consistent with the overall decreased in TGF- $\beta$ expression, the levels of Col1a1 and Col1a3 expression were also significantly decreased in the group treated with IGF-1+MSC and in the control group when compared with the untreated group. However, when analyzing the IGF-1 or MSC administration individually, 
there was a statistical decreased of Col1a1 only in the IGF-1 treated group (FIGURE 5C).

Association of both MSC and IGF-1 modulates inflammation through reduction of inflammatory molecules in skeletal muscle of LAMA2 ${ }^{\text {dy/2j }}$ dystrophic model. A further complication that exacerbates muscular dystrophy is the persistence of inflammation (Mourkioti and Rosenthal, 2005; Pelosi et al., 2007). To verify whether the improvement in muscular strength observed in the IGF-1+MSC group was also associated with a modulation of the inflammatory response, we examined expression patterns of specific cytokines and chemokines related with the infiltration of inflammatory cells into damaged muscle (FIGURE 6). Western blot analysis showed that the levels of TNF-a, an important mediator of the early inflammatory response, decreased significantly in the IGF-1+MSC treated animals, when compared with untreated LAMA2 ${ }^{d y / 2 j}$ mice. Conversely, higher TNF- $\alpha$ levels were found in mice treated with either IGF-1 or MSCs individually, relative to control levels (FIGURE 6A). At later stages, the inflammatory response to muscle injury is associated with elevated expression of CC chemokines involved in the recruitment of monocytes/macrophages. A significant decrease in CCL2 expression was observed in IGF-1, MSC, and IGF1+MSC-treated mice, when compared with untreated dystrophic mice (FIGURE 6B). Notably, the CCL8 expression was significantly decreased only in IGF-1+MSC treated mice. Similarly, only the association of IGF-1+MSC decreased significantly the RNA levels of CCL3 (FIGURE 6B). As shown in FIGURE 6B, IGF-1 only and IGF-1+MSC groups presented significantly reduced levels of CCL5 in comparison with untreated 
group, while MSC group presented an increased expression of these same chemokines. Finally, our results did not reveal significant differences in the expression of IkB- $\alpha$ - the inhibitory protein of the NFk-B, one of the central players of the inflammatory system - between the untreated and treated dystrophic mice (FIGURE 6B).

Association of both MSC and IGF-1 contributes to the regeneration process in Lama2 ${ }^{d y / 2 j}$ dystrophic muscle. Attenuation of the inflammatory response is beneficial to muscle repair (Mourkioti and Rosenthal, 2005; Pelosi et al., 2007). To verify whether the mild inflammatory response observed in IGF1+MSC group was associated with enhanced muscle regeneration, we examined the expression levels of proteins involved in myogenesis, including myogenin, MyoD, Pax7 and MRF4 (FIGURE 7). Western blot analysis revealed significantly increased levels of myogenin in IGF-1, MSC and IGF-1+MSC treated $\mathrm{LAMA}^{d y / 2 j}$ mice when compared with untreated dystrophic mice (FIGURE 7A). Control groups, on the other hand, showed a significantly decrease in myogenin protein expression relative to dystrophic mice. Although IGF-1 or MSC treatments alone somewhat induced MyoD expression, significantly higher levels of MyoD were only found in mice subjected to the combined IGF-1+MSC treatment (FIGURE 7A). Real-time Quantitative RT-PCR analysis demonstrated a significantly increase in myogenin expression only in MSCs group. On the other hand, transcript levels of MyoD and MRF4 were similar between the untreated and treated dystrophic mice (FIGURE 7B). In accordance with the increase in the number of newly regenerated fibers represented by the centrally nucleated fibers - observed in TA muscle of only 
MSCs-treated mice, the up-regulation of myogenin expression provides further evidence that MSCs transplantation can enhance the regeneration of dystrophic muscle. Moreover, the increased myogenin and MyoD expression may contribute to enhance muscle regeneration and, therefore, improve the muscular strength observed in IGF-1+MSCs co-treated mice.

\section{Association of both MSC and IGF-1 affects expression of proteins related with proteolytic systems in muscle of LAMA2 $2^{d y / 2 j}$ dystrophic model.} Considering that the protein breakdown has been postulated to be one of the intrinsic factors responsible for muscle wasting, we studied the expression of proteins related to proteolytic systems. As it can be observed in FIGURE 8A, only the association of both IGF-1+MSCs decreased significantly the protein levels of Murf-1, an important protein of the proteolytic pathways activated in several pathologies, in comparison with the untreated dystrophic mice. MSCtreated group also presented lower levels of Murf-1 protein, but these values did not reach a statistical significance. In contrast, the Murf-1 protein levels were similar in IGF-1 treated group and untreated group. Furthermore, we also examined the expression of calpain-1, -2 and calpastatin, since the calpain/calpastatin system-mediated protein degradation is an important proteolytic pathway activated during myofiber degeneration (FIGURE 8 B-D). We observed that protein levels of calpain-1 and calpain-2 remained unchanged in untreated and treated dystrophic mice (FIGURE 8B,C). However, significant differences in the expression of calpastatin - an endogenous calpain inhibitor were verified between the IGF-1+MSC treated mice and untreated mice; 
western blot analysis revealed that the association of both IGF-1+MSC resulted in an increased calpastatin protein level (FIGURE 8D). Although not significant, we also observed increased levels of calpastatin in mice muscles treated with IGF-1 or MSC separately (FIGURE 8D).

Association of both MSC and IGF-1 do not change calcium handling protein expression in the muscle of LAMA2 ${ }^{d y / 2 j}$ dystrophic model. Finally, we analyzed NCX and SERCA1 expression to assess if treatment with IGF-1 and MSCs would change the expression of proteins related with calcium influx, the main contributor to skeletal muscle functional and structural abnormalities. However, as shown in FIGURE 9, there were no statistical differences among groups.

\section{DISCUSSION}

IGF-1 enhances the myogenic differentiation of MSCs from UC and the interaction between MSCs and DMD muscle cells in vitro. IGF-1 is one of the most potent factors mediating muscle growth, and has been shown to prevent muscle wasting associated with neuromuscular disease. Several studies have already demonstrated that IGF-1 is responsible for activating both myoblast proliferation and subsequent differentiation, two processes that are crucial for muscle regeneration (Mills et al., 2007; Mourkioti and Rosenthal, 2005). Since the effects of IGF-1 on the myogenic differentiation have only been 
tested on muscular progenitor cells, we analyzed, for the first time, these events on human MSCs.

Our in vitro data demonstrated that IGF-1 enhanced myogenic differentiation of MSCs when added as a supplement in usual muscle induction medium containing HS. Western blot data showed that IGF-1-induced myogenic differentiation is accompanied by the sequential expression of early, intermediate, and late MRFs, such as Pax7, MyoD, and Myogenin, respectively, comparable to what occurs during embryonic development and skeletal muscle regeneration. Interestingly, we also demonstrated that the continuous IGF-1 exposure in MSCs cultures resulted in a robust increase in the levels of later myogenic markers, such as Desmin, MyHC, and Dystrophin, observed as early as eight days of myogenic differentiation induction. This data suggest that IGF-1 is able to rapidly induce an efficient myogenic conversion of MSCs with formation of mature myotubes in vitro.

The in vitro myogenic conversion evidenced here, when MSCs were cultured in medium supplemented with IGF-1, is considerably greater than any other previously reported with human MSCs from UC. Although MSCs are characterized by their potential to differentiate into multiple mesenchymal lineages, myogenesis has proven to be much more difficult to induce (Goudenege et al., 2009; Gang et al., 2009). In fact, most studies have only demonstrated their capacity to differentiate into bone, fat, cartilage, and connective tissue. Chan et al. (2006) described a highly efficient protocol to induce myogenic differentiation of fetal MSCs, by their exposure to galactin-1. However, it is not known yet whether these protocols can be reproduced for 
adult MSCs. Although Gang et al. (2004) demonstrated muscle differentiation by expression of later myogenic markers, such as $\mathrm{MyHC}$, in up to $56 \%$ of umbilical cord blood-derived MSCs, this result was achieved after a long myogenic differentiation protocol, which lasted up to six weeks. Recently, other authors have described an efficient myogenic induction program in MSCs by overexpression of factors involved in myogenesis (Gang et al., 2008; Gang et al., 2009; Wagner et al., 2009; Goudenege et al., 2009; Kocaefe et al., 2010; Nitahara-Kasahara et al., 2011). However, the transfection of these factors may affect subsequent cell function/metabolism both in vitro and in vivo. Barberi et al. (2005) demonstrated that $10 \%$ of mesenchymal progenitor cells derived from human embryonic stem cells could fuse with $\mathrm{C} 2 \mathrm{C} 12$ cells in co-culture. Interestingly, our group has also previously demonstrated that MSCs from adipose tissue when co-cultured with DMD muscle cells were able to fuse into muscle cells and reestablish dystrophin expression (Vieira et al., 2008a).

Although here we investigated MSCs from another source, we show that IGF-1, when added to co-cultures of MSCs from UC and DMD muscle cells, enhance the fusion of MSCs with myoblasts as well as myotubes, restoring the dystrophin expression in both situations. These results further reinforce two mechanisms for the contribution of IGF-1 signaling to muscle differentiation: de novo generation of muscle-specific cells by the fusion of myoblasts - a process known as hyperplasia - or the fusion of myoblasts with preexisting muscle fibers and myofiber maturation, characterizing the process known as hypertrophy. In vitro expression of dystrophin supports the hypothesis that MSCs from UC, when associated with IGF-1 have the potential to be used 
for Duchenne muscular dystrophy therapy and, therefore, should be further tested as a potential therapeutic approach.

\section{Association of IGF-1 and MSCs improves skeletal muscular strength in}

LAMA2 ${ }^{d y / 2 j}$ dystrophic mice. Although a growing body of evidences suggests a clear therapeutic potential of MSCs for a variety of diseases, including muscular dystrophies, some questions remain to be addressed before embarking in clinical application (Kerkis et al., 2008; Vieira et al., 2008; Gang et al., 2009; Vieira et al., 2010; Vieira et al., 2011; Nitahara-Kasahara et al., 2011; da Justa Pinheiro et al., 2011). To first elucidate if the association of IGF-1 and MSCs could be beneficial to muscle repair and strength we performed in vivo studies, using a murine model for congenital muscular dystrophy. In muscular dystrophy patients there is a significant muscle fiber degeneration that exhausts the pool of progenitor muscle cells able to proliferate and replace damaged fibers (Heslop et al., 2000). Therefore, the identification of alternative cells sources and the understanding on their potential mechanism on muscle repair and maintenance is extremely important to evaluate cell therapy strategies. Recent studies have attempted to optimize MSC-based therapeutics by enhancing their survival, potency, and/or delivery to target tissue, through overexpression of trophic factors or administration of potency-enhancing factors (Wagner et al., 2009). The present study showing IGF-1 role in promoting myogenic differentiation of MSCs - obtained in our tests in vitro - and their other effects in muscle regeneration published by others, support the hypothesis that it may improve MSCs transplantation. To further investigate if IGF-1 together with MSCs would 
benefit muscle repair, we performed in vivo studies, using a murine model for congenital muscular dystrophy. Previous studies have obtained encouraging results following IGF-1 treatment or transplantation of different stem cell preparations into mouse models of muscular dystrophy (Kerkis et al., 2008; Vieira et al., 2008; Gang et al., 2009; Vieira et al., 2010; Vieira et al., 2011; Nitahara-Kasahara et al., 2011; da Justa Pinheiro et al., 2011; Barton et al., 2002; Gehrig et al., 2008; Kumar et al., 2011). However, we are not aware of any reported pre-clinical study testing the IGF-1 effects on MSCs transplantations. Moreover, most of these studies were performed in DMD murine model $-m d x$ - that has no evident muscular weakness and therefore is not the best model to assess potential functional effects of different therapeutic approaches. Mouse models for congenital muscular dystrophy, including the allelic mutant LAMA $2^{d y / 2 j}$ mouse that we used here, present a significant reduction of a2-laminin in muscle and an extremely severe phenotype (Vainzof et al., 2008).

Since a significant obstacle in designing a therapy for muscular dystrophies is the necessity to reach the entire body musculature, a problem that cannot be easily overcome unless systemic delivery methods are proved to be effective, we performed a systemically administration of both IGF-1 and MSC. Previous studies have already proposed different methods to increase the IGF-1 levels during muscle regeneration, including virus-mediated IGF-1 overexpression. However, it is important to point out the side effects and the cytotoxicity associated to viral-mediated gene delivery. In our tests, we did not find any evidence of side effects, followed by the continuous administration of 
IGF-1 protein for eight weeks, MSCs injections or both treatments combined. On the other hand, our results suggest a clear beneficial effect in the animals submitted to both IGF-1+MSCs. Previous studies have already documented that the dystrophic mice present elevated cholesterol content in muscle and serum as a result of the progressive substitution of skeletal muscle by connective and fatty tissue (Brazeau et al., 1992; Heatwole et al., 2011). Contrary to that, here we showed that the cholesterol levels in the animals submitted to both IGF$1+\mathrm{MSC}$ were significantly decreased in comparison to untreated dystrophic animals. Moreover, although it has been reported that the chronic administration of IGF-1 leads to insulin-like hypoglycemic effects (Heatwole et al., 2011), our results demonstrated that the IGF-1 treated animals presented an increase in the glucose levels in comparison with the untreated dystrophic animals, similar to those observed in non-dystrophic control mice. Although further studies are necessary to monitor long-term effects, the present investigation suggests that the continuous IGF-1 administration at a relatively low dose for eight weeks is apparently safe and does not cause evident severe side effects.

Finally, our results demonstrated that only the association of both IGF-1+MSCs resulted in significant functional improvements of treated in LAMA $^{d y / 2 j}$ in comparison to untreated, IGF-1 and MSCs groups. To further understand the effects of IGF-1 associated with MSCs in muscle repair, we firstly analyzed if IGF-1 was able to promote muscle engraftment and myogenic differentiation of MSCs after their systemic delivery. 
MSCs from UC injected systemically in dystrophic mice were able to reach the skeletal muscle from LAMA2 ${ }^{d y / 2 j}$ mice but did not differentiate into muscle cells, even when associated with IGF-1. Our results showed that human MSCs from UC were not rejected and can reach and engraft into recipient dystrophic muscle cells after systemic delivery, even without immunosuppression. On the other hand, since we did not find human dystrophin in skeletal muscle of MSCs injected mice, it seems unlikely that MSCs have differentiated to muscle cells.

Considering that dystrophin is a later myogenic marker, we cannot exclude the possibility that the injected cells were in earlier stages of myogenesis. However, most importantly is that we observed a functional recovery in the animals treated with IGF-1+MSC. Therefore, it is possible that dystrophin expression is not required for a significant functional amelioration, as it has been recently suggested by a growing body of evidences. Several animal models for DMD have shown that muscle can be functional despite the absence of dystrophin, including the $m d x$ murine model and also larger exceptional animals such as the golden retriever muscular dystrophy or Labrador muscular dystrophy dogs described previously (Zatz et al., 2010; Zucconi et al., 2010; Diane Shelton, personal communication). On the other hand, Gang et al. (2009) reported that MSCs could restore dystrophin expression when injected into dystrophin-deficient mouse, but this effect was not accompanied by functional recovery. Conversely, our group demonstrated that human MSCs from UC injected in a sjl mice model were able to reach the muscle and promote a therapeutic benefit in injected animals, although not expressing human 
dystrophin (Vieira et al., 2010). Supporting these findings, several evidences have indicated that terminal differentiation is not a major determinant for the success of stem cell therapy (Gang et al., 2009; English et al., 2010; Gharaibeh et al., 2011; da Justa Pinheiro et al., 2011; Caplan \& Correa, 2011). These authors reported that MSCs contribute to tissue repair through the production of trophic factors, including growth factors, cytokines and antioxidants, some of which providing the basis for their capacity to modulate inflammatory and/or immune responses (Ichim et al., 2010; English et al., 2010; da Justa Pinheiro et al., 2011; Caplan \& Correa, 2011). In order to explore how the association of IGF-1 and MSC could enhance muscle repair, we analyzed some aspects related with muscle inflammation and/or fibrosis and regeneration process.

\section{Association of both MSC and IGF-1 modulates inflammation and reduces fibrosis in skeletal muscle of LAMA2 ${ }^{\text {dy/2j }}$ dystrophic model. Muscle} regeneration and repair occur in four interdependent stages: degeneration, inflammation, regeneration, and fibrosis. Inflammation is clearly a critical component of the regenerative process, since it contributes to the removal of the necrotic material and also to the secretion of several cytokines and growth factors stimulating progenitor muscle cells activation (Mourkioti and Rosenthal, 2005; Pelosi et al., 2007). Nevertheless, the inflammatory response must be resolved to allow muscle repair and prevent the replacement of skeletal muscle by fibrotic tissue (Pelosi et al., 2007; Mourkioti and Rosenthal, 2005). Regarding the inflammation, our results demonstrated that only in the group in which MSCs were associated with IGF-1 administration, there was a significantly decreased 
expression of pro-inflammatory cytokines, such as TNF- $\alpha$ and the CC chemokines. Several works have reinforced the anti-inflammatories proprieties of IGF-1 as well as MSCs (Pelosi et al., 2007; Ichim et al., 2010; da Justa Pinheiro et al., 2011). Indeed our results demonstrated that CCL2, CCL3 and CCL8 expression was also decreased in the muscle of animals treated with IGF1 or MSC alone although these values did not reach a statistical significance. It is possible that additive effects produced by the association of IGF-1 and MSCs are responsible for the significant reduction of these cytokines and chemokines observed here.

These cytokines and chemokines are associated with sustained influx of inflammatory cells into damaged muscle and to the switch from acute to a chronic inflammatory process and, consequently, onset of the fibrotic process. Therefore, their down-regulation could contribute to accelerate the timing of inflammation and to limit the fibrosis (Pelosi et al., 2007). Although the IGF-1 group presents some minor signs of decreased fibrosis, only the muscle of animals submitted to both procedures (IGF+MSCs) presented significant evidences of fibrosis reduction, such as decreased interstitium in muscle sections and down-regulation of specific proteins related with the fibrous tissue formation. It has been previously demonstrated that IGF-1 contributes to prevent the fibrosis in several pathological conditions, but more recent studies have reported that IGF-1 alone was not able to alter the extent of collagen infiltration in dystrophic murine models (Gehrig et al., 2008; Kumar et al., 2011). Similarly, there are conflicting results about MSCs anti-fibrotic proprieties: in opposition to the evidences showing that MSCs are able to reduce fibrosis, some authors have demonstrated that MSCs induce an increased expression of TGF- $\beta$, a 
cytokine responsible to mediate the fibrotic process (Puissant et al., 2005; Lee et al., 2010; Ohnishi et al., 2007). Corroborating with this last point, our results showed that MSCs treated-group revealed an unchanged expression or a slightly increase of TGF- $\beta$ levels, as well as, of Col1a1 and Col3a1 expression in comparison with untreated dystrophic mice. These results suggest that MSCs could limit or increase fibrosis extent according to different conditions of the tissue microenvironment.

In short our data provide the initial evidence that the prominent pathogenic features of muscular dystrophies that lead to muscle dysfunction and clinical weakness - such as chronic inflammation and fibrosis - were diminished when IGF-1 and MSCs were associated. Considering that no effective pharmacotherapy exists to attenuate muscle necrosis or fibrosis in patients with muscular dystrophy without considerable side effects, our results are of utmost clinical importance.

\section{Association of both MSC and IGF-1 contributes to the muscular regeneration process and prevents the skeletal muscle wasting of} LAMA2 $^{\text {dy/2j }}$ dystrophic model. If a decreased inflammatory response and fibrosis might create a qualitatively different environment for sustaining more efficiently muscle regeneration, the down-regulation of growth factors, cytokines and chemokines pro-inflammatory and pro-fibrotic could be responsible for the muscle repair observed in our animals treated with both IGF-1 and MSCs. Interestingly, we observed that muscle regenerative markers such as the myogenic regulatory factors, MyoD and Myogenin were expressed at significantly higher levels in the group treated with both IGF-1+MSC. The 
animals submitted only to IGF-1 or MSCs also demonstrated an increase in myogenin expression by Western Blot analysis. The MSCs group also showed an increased myogenin expression assessed by Real-time Quantitative RTPCR, as well as, in the number of centronucleated fibers in TA muscle. Since it has already been reported that IGF-1 prevents cell death, it is possible that the reduced number of centrally nucleated myofibers in animals submitted to IGF-1 or IGF-1+MSC, may be a result of considerable reduction in fiber necrosis/damage eliminating the need for a pronounced regeneration. A previous study in another mouse model of laminin-2 deficiency demonstrated that muscle IGF-1 overexpression alone was able to improve muscle regeneration - evidenced by the increased number of centronucleated fibers without reducing inflammation and fibrosis (Kumar et al., 2011). It is possible that much more aggressive muscle degeneration that cannot be compensated by improved regeneration alone is occurring in these mice compared with LAMA2 ${ }^{d y / 2 j}$ mice co-treated here, creating an environment for fibroblasts to infiltrate and promote fibrosis. These data reinforce the need to develop a combined therapy to target the multiple disease drivers in CMD1A.

H\&E analysis also demonstrated that a relatively low dose of IGF-I administration and/or MSC injections did not cause myofiber hypertrophy in the muscle of treated mice in this or previous studies, as evidenced by changes in the fibers CSA (Gregorevic et al., 2002, 2004; Gehrig et al., 2008). On the other hand, other studies have also showed that a similar regimen of exogenous IGF-I administration or IGF-1 overexpression caused hypertrophy of the dystrophic fibers (Musaro et al., 2001; Lynch et al., 2001; Barton et al., 2002; Kumar et al., 
2011). Discrepancies regarding the effects of IGF-I on muscle hypertrophy may be due to the dose and timing of IGF-I employed and the experimental animal model used to test its effects. Further research is required to unravel the intracellular signaling cascades that may be responsible for these differences.

Besides the increased muscle regeneration capacity, we also observed that the association of IGF-1+MSCs caused significantly changes in the expression of proteins related with proteolytic systems in muscles of LAMA $^{d y / 2 j}$ dystrophic model, including Murf- 1 and calpastatin. If the primary cause of the rapid loss of mass muscle is the accelerated protein degradation, down-regulation of proteins responsible for proteolysis could help prevent muscle wasting (Scicchitano et al., 2009), as observed in animals submitted to both IGF-1+MSC. Corroborating our findings, previous studies have already showed that IGF-1 alone can result in the decrease of Murf-1 expression, as well as, the increase of calpastatin, which are important modulators of the proteolytic systems during muscle atrophy (Wingertzahn et al., 1998). However, this is the first report addressing the effects of MSCs and/or association of IGF-1 and MSCs in skeletal muscle wasting induced by increased protein breakdown.

In summary, our study demonstrated that IGF-1 is able to promote a robust myogenic differentiation of MSCs in vitro and to contribute to enhance the interaction between MSCs and DMD muscle cells in co-cultures. Furthermore, our in vivo studies showed, for the first time, that the association of IGF-1 and MSCs has a positive complementary and/or additive effect improving muscle function and reducing skeletal muscle pathology in a murine model of 
congenital muscular dystrophy. In addition, we showed that these effects are related with modulation of the inflammatory response and reduction of fibrosis. Moreover, since we could not find human muscle specific protein in skeletal muscles of injected mice, it is more plausible to suggest that muscle regeneration improvement in dystrophic mice subjected to a combined treatment with IGF-1 and MSC is correlated mainly with enhanced activation of progenitor cells and/or satellite cells rather than myogenic differentiation of injected MSCs. These results may have important applications for future therapy in patients with different forms of muscular dystrophies. 


\section{Acknowledgements}

The collaboration of the following persons is gratefully acknowledged: Members from University Hospital, Constancia Urbani, Marcos Valadares, Tatiana Jazedje, Eder Zucconi, Estela Cruvinel, Carla Freitas, Juliana Gomes, Amanda Assoni, Gabriela Polster, Heloisa Caetano, Paula Onofre, Marta Canovas, Fernando Luis Molina, Dra. Maria Rita Passos-Bueno, for helpful suggestions. We would like to thank Dr. Glenn Morris from the Center for Inherited Neuromuscular Disease (CIND), RJAH Orthopaedic Hospital, Oswestry, Shropshire, UK for providing anti-human dystrophin antibody. This work was supported with grants of CEPID-FAPESP (Centro de Pesquisa, Inovação e Difusão-Fundação de Amparo a Pesquisa do Estado de São Paulo), CNPq (Conselho Nacional de Desenvolvimento Científico e Tecnológico), INCT (Instituto Nacional de Ciência e Tecnologia)

\section{Disclosures}

The authors indicate no potential conflicts of interest. 


\section{REFERENCES:}

Barton, E.R., Morris, L., Musaro, A., Rosenthal, N., and Sweeney, H.L. (2002). Musclespecific expression of insulin-like growth factor I counters muscle decline in mdx mice. J. Cell Biol. 157, 137-148.

Benchaouir, R., Meregalli, M., Farini, A., D'Antona, G., Belicchi, M., Goyenvalle, A., Battistelli, M., Bresolin, N., Bottinelli, R., Garcia, L., et al. (2007). Restoration of human dystrophin following transplantation of exon-skipping-engineered DMD patient stem cells into dystrophic mice. Cell Stem Cell. 1, 646-657.

Brazeau, G.A., Mathew, M., and Entrikin, R.K., (1992). Serum and organ indices of the mdx dystrophic mouse. Res. Commun. Chem. Pathol. Pharmacol. 77, 179-189.

Caplan, A.I., and Correa, D. (2011). The MSC: an injury drugstore. Cell Stem Cell 9, 1115.

Chamberlain, J.R., and Chamberlain, J.S. (2010). Muscling in: Gene therapies for muscular dystrophy target RNA. Nat Med. 16, 170-171.

Chan, J., O'Donoghue, K., Gavina, M., Torrente, Y., Kennea, N., Mehmet, H., Stewart, H., Watt, D.J., Morgan, J.E., and Fisk, N.M. (2006). Galectin-1 induces skeletal muscle differentiation in human fetal mesenchymal stem cells and increases muscle regeneration. Stem Cells. 24, 1879-1891.

Da Justa Pinheiro, C.H., De Queiroz, J.C., Guimarães-Ferreira, L., Vitzel, K.F., Nachbar, R.T., De Sousa, L.G., De Souza-Jr, A.L., Nunes, M.T., and Curi, R. (2011). Local Injections of Adipose-Derived Mesenchymal Stem Cells Modulate Inflammation and Increase Angiogenesis Ameliorating the Dystrophic Phenotype in DystrophinDeficient Skeletal Muscle. Stem Cell Rev. [Epub ahead of print].

Dalkilic, I., and Kunkel, L.M. (2003). Muscular dystrophies: genes to pathogenesis. Curr. Opin. Genet. Dev. 13, 231-238.

Dubowitz, V. (1999). 68th ENMC international workshop: On Congenital Muscular Dystrophy, 9-11, April 1999, Naarden, The Netherlands: Neuromuscul. Disord. 9, 446454.

Ehmsen, J., Poon, E., and Davies, K. (2002). The dystrophin-associated protein complex. J. Cell Sci. 115, 2801-2803.

Emery, A.E. (2002). The muscular dystrophies. Lancet 359, 687-695.

English, K., French, A., and Wood, K.J. (2010). Mesenchymal stromal cells: facilitators of successful transplantation? Cell Stem Cell 7, 431-442. 
Gang, E.J., Jeong, J.A., Hong, S.H., Hwang, S.H., Kim, S.W., Yang, I.H., Ahn, C., Han, $\mathrm{H}$., and Kim, H. (2004). Skeletal myogenic differentiation of mesenchymal stem cells isolated from human umbilical cord blood. Stem Cells. 22, 617-624.

Gang, E.J., Bosnakovski, D., Simsek, T., To, K., and Perlingeiro, R.C. (2008). Pax3 activation promotes the differentiation of mesenchymal stem cells toward the myogenic lineage. Exp. Cell Res. 314, 1721-1733.

Gang, E.J., Darabi, R., Bosnakovski, D., Xu, Z., Kamm, K.E., Kyba, M., and Perlingeiro, R.C., (2009). Engraftment of mesenchymal stem cells into dystrophin-deficient mice is not accompanied by functional recovery. Exp. Cell Res. 315, 2624-2636.

Gehrig, S.M., Ryall, J.G., Schertzer, J.D., and Lynch, G.S. (2008). Insulin-like growth factor-I analogue protects muscles of dystrophic $\mathrm{mdx}$ mice from contraction-mediated damage. Exp. Physiol. 93, 1190-1198.

Goudenege, S., Pisani, D.F., Wdziekonski, B., Di Santo, J.P., Bagnis, C., Dani, C., and Dechesne, C.A. (2009). Enhancement of myogenic and muscle repair capacities of human adipose-derived stem cells with forced expression of MyoD. Mol. Ther. 17, 1064-1072.

Gregorevic, P., Plant, D.R., and Lynch, G.S. (2004). Administration of insulin-like growth factor-I improves fatigue resistance of skeletal muscles from dystrophic $\mathrm{mdx}$ mice. Muscle Nerve. 30, 295-304.

Gregorevic, P., Plant, D.R., Leeding, K.S., Bach, L.A., and Lynch, G.S. (2002). Improved contractile function of the $\mathrm{mdx}$ dystrophic mouse diaphragm muscle after insulin-like growth factor-I administration. Am. J. Pathol. 161, 2263-2272.

Heatwole, C.R., Eichinger, K.J., Friedman, D.I., Hilbert, J.E., Jackson, C.E., Logigian, E.L., Martens, W.B., McDermott, M.P., Pandya, S.K, Quinn, C. et al (2011). Open-label trial of recombinant human insulin-like growth factor $1 /$ recombinant human insulin-like growth factor binding protein 3 in myotonic dystrophy type 1. Arch Neurol. 68, 37-44.

Heslop, L., Morgan, J.E., and Partridge, T.A. (2000). Evidence for a myogenic stem cell that is exhausted in dystrophic muscle. Journal of Cell Science 113, 2299-2308.

Howad, M.T., Anderson, C.B., Fass, U., Khatri, S., Gesteland, R.F., Atkins, J.F., and Flanigan, K.M. (2004). Readthrough of dystrophin stopcodon mutations induced by aminoglycosides. Ann. Neurol. 55, 422-426.

Jones, K.J., Kim, S.S., and North, K.N. (1998). Abnormalities of dystrophin, the sarcoglycans, and laminin alpha2 in the muscular dystrophies. J. Med. Genet. 35, 379386. 
Kerkis, I., Ambrosio, C.E., Kerkis, A., Martins, D.S., Zucconi, E., Fonseca, S.A., Cabral, R.M., Maranduba, C.M., Gaiad, T.P., Morini, A.C., et al. (2008). Early transplantation of human immature dental pulp stem cells from baby teeth to golden retriever muscular dystrophy (GRMD) dogs: local or systemic? J. Transl. Med. 6, 35.

Kocaefe, C., Balci, D., Hayta, B.B., and Can, A. (2010). Reprogramming of human umbilical cord stromal mesenchymal stem cells for myogenic differentiation and muscle repair. Stem Cell Rev. 6, 512-522.

Kumar, A., Yamauchi, J., Girgenrath, T., and Girgenrath, M. (2011). Muscle-specific expression of insulin-like growth factor 1 improves outcome in Lama2Dy-w mice, a model for congenital muscular dystrophy type 1A. Hum. Mol. Genet. 20, 2333-2343.

Lee, M.J., Jung, J., Na, K.H., Moon, J.S., Lee, H.J., Kim, J.H., Kim, G.I., Kwon, S.W., Hwang, S.G., and Kim G.J. (2010). Anti-fibrotic effect of chorionic platederived mesenchymal stem cells isolated from human placenta in a rat model of $\mathrm{CCl}(4)$ injured liver: potential application to the treatment of hepatic diseases. J. Cell Biochem. $111,1453-1463$.

Lin, Y., Liu, L., Li, Z., Qiao, J., Wu, L., Tang, W., Zheng, X., Chen, X., Yan, Z., Tian, W. (2006). Pluripotency potential of adipose-derived stem cells marked withexogenous green fluorescent protein. Mol. Cell Biochem. 291, 1-10.

Lynch, G.S., Cuffe, S.A., Plant, D.R, and Gregorevic, P. (2001). IGF-I treatment improves the functional properties of fast- and slow-twitch skeletal muscles from dystrophic mice. Neuromuscul. Disord. 11, 260-268.

Mills, P., Dominique, J.C., Lafrenière, J.F., Bouchentouf, M., and Tremblay, J.P. (2007). A synthetic mechano growth factor $E$ Peptide enhances myogenic precursor cell transplantation success. Am J. Transplant. 7, 2247-2259.

Mourkioti, F., and Rosenthal, N. (2005). IGF-1, inflammation and stem cells: interactions during muscle regeneration. Trends Immunol. 26, 535-42.

Musarò, A., McCullagh, K., Paul, A., Houghton, L., Dobrowolny, G., Molinaro, M., Barton, E.R., Sweeney, H.L., and Rosenthal, N. (2001). Localized Igf-1 transgene expression sustains hypertrophy and regeneration in senescent skeletal muscle. Nat Genet. 27, 195-200.

Nitahara-Kasahara, Y., Hayashita-Kinoh, H., Ohshima-Hosoyama, S., Okada, H., Wada-Maeda, M., Nakamura, A., Okada, T., and Takeda S. (2011). Long-term Engraftment of Multipotent Mesenchymal Stromal Cells That Differentiate to Form Myogenic Cells in Dogs With Duchenne Muscular Dystrophy. Mol. Ther. [Epub ahead of print].

O'Brien, K.F., and Kunkel, L.M. (2001). Dystrophin and muscular dystrophy: past, present, and future. Molecular Genetics and Metabolism 74, 75-88. 
Ohnishi, S., Sumiyoshi, H., Kitamura, S., and Nagaya, N. (2007). Mesenchymal stem cells attenuate cardiac fibroblast proliferation and collagen synthesis through paracrine actions. FEBS Lett. 581, 3961-3966.

Pelosi, L., Giacinti, C., Nardis, C., Borsellino, G., Rizzuto, E., Nicoletti, C., Wannenes, F., Battistini, L., Rosenthal, N., Molinaro, M., et al. (2007). Local expression of IGF-1 accelerates muscle regeneration by rapidly modulating inflammatory cytokines and chemokines. FASEB J. 21, 1393-1402.

Petrof, B.J., Shrager, J.B., Stedman, H.H., Kelly, A.M. and Sweeney, H.L. (1993). Dystrophin protects the sarcolemma from stresses developed during muscle contraction. Proc Natl Acad Sci U S A 90, 3710-3714.

Puissant, B., Barreau, C., Bourin, P., Clavel, C., Corre, J., Bousquet, C., Taureau, C., Cousin, B., Abbal, M., Laharrague P., et al. (2005). Immunomodulatory effect of human adipose tissue-derived adult stem cells: comparison with bone marrow mesenchymal stem cells. Br. J. Haematol. 129, 118-129.

Rando, T.A. (2001). The dystrophin-glycoprotein complex, cellular signaling, and the regulation of cell survival in the muscular dystrophies. Muscle Nerve 24, 1575-1594.

Rouger, K., Larcher, T., Dubreil, L., Deschamps, J.Y., Le Guiner, C., Jouvion, G., Delorme, B., Lieubeau, B., Carlus, M., Fornasari, B. et al. (2011). Systemic Delivery of Allogenic Muscle Stem (MuStem) Cells Induces Long-Term Muscle Repair and Clinical Efficacy in Duchenne Muscular Dystrophy Dogs. Am. J. Pathol. [Epub ahead of print].

Sacco, A., Doyonnas, R., LaBarge, M.A., Hammer, M.M., Kraft, P., and Blau, H.M. (2005). IGF-I increases bone marrow contribution to adult skeletal muscle and enhances the fusion of myelomonocytic precursors. J. Cell Biol. 171, 483-492.

Sampaolesi, M., Blot, S., D'Antona, G., Granger, N., Tonlorenzi, R., Innocenzi, A., Mognol, P., Thibaud, J.L., Galvez, B.G., Barthélémy, I., et al. (2006). Mesoangioblast stem cells ameliorate muscle function in dystrophic dogs. Nature 444, 574-579.

Scicchitano, B.M., Rizzuto, E., and Musarò, A. (2009). Counteracting muscle wasting in aging and neuromuscular diseases: the critical role of IGF-1. Aging (Albany NY). 1, 451-457.

Secco, M., Moreira, Y.B., Zucconi, E., Vieira, N.M., Jazedje, T., Muotri, A.R., Okamoto, O.K., Verjovski-Almeida, S., and Zatz, M. (2009). Gene expression profile of mesenchymal stem cells from paired umbilical cord units: cord is different from blood. Stem Cell Rev. 5, 387-401. 
Secco, M., Zucconi, E., Vieira, N.M., Fogaça, L.L., Cerqueira, A., Carvalho, M.D., Jazedje, T., Okamoto, O.K., Muotri, A.R., and Zatz, M. (2008a). Multipotent stem cells from umbilical cord: cord is richer than blood! Stem Cells 26, 146-150.

Secco, M., Zucconi, E., Vieira, N.M., Fogaça, L.L., Cerqueira, A., Carvalho, M.D., Jazedje, T., Okamoto, O.K., Muotri, A.R., and Zatz, M. (2008b). Mesenchymal stem cells from umbilical cord: do not discard the cord! Neuromuscul. Disord. 18, 17-18.

Vainzof, M., Ayub-Guerrieri, D., Onofre, P.C., Martins, P.C., Lopes, V.F., Zilberztajn, D., Maia, L.S., Sell, K., and Yamamoto, L.U. (2008). Animal models for genetic neuromuscular diseases. J. Mol. Neurosci. 34, 241-248.

Vieira, N. M., Bueno, C.R. Jr., Brandalise, V., Moraes, L.V., Zucconi, E., Secco, M., Suzuki, M.F., Camargo, M.M., Bartolini, P., Brum, P.C., et al. (2008). Sjl dystrophic mice express a significant amount of human muscle proteins following systemic delivery of human adipose-derived stromal cells without immunosupression. Stem Cells 26, 2391-2398.

Vieira, N. M., Valadares, M., Zucconi, E., Secco, M., Bueno, C.R. Jr., Brandalise, V., Assoni, A., Gomes, J., Landini, V., Andrade, T., et al. (2011). Human Adipose-Derived Mesenchymal Stromal cells injected systemically into GRMD dogs without immunosupression are able to reach the host muscle and express human dystrophin. Cell Transplant. [Epub ahead of print].

Vieira, N.M., Brandalise, V., Zucconi, E., Jazedje, T., Secco, M., Nunes, V.A., Strauss, B.E., Vainzof, M., and Zatz, M. (2008a). Human multipotent adipose-derived stem cells restore dystrophin expression of Duchenne skeletal-muscle cells in vitro. Biol. Cell. 100, 231-41.

Vieira, N.M., Zucconi, E., Bueno, C.R. Jr., Secco, M., Suzuki, M.F., Bartolini, P., Vainzof, M., and Zatz, M. (2010) Human multipotent mesenchymal stromal cells from distinct sources show different in vivo potential to differentiate into muscle cells when injected in dystrophic mice. Stem Cell Rev. 6, 560-566.

Wagner, J., Kean, T., Young, R., Dennis, J.E., and Caplan, A.I. (2009). Optimizing mesenchymal stem cell-based therapeutics. Curr. Opin. Biotechnol. 20, 531536.

Wells, K.E., Fletcher, S., Mann, C.J., Wilton, S.D., and Wells, D.J. (2003). Enhanced in vivo delivery of antisense oligonucleotides to restore dystrophin expression in adult $\mathrm{mdx}$ mouse muscle. FEBS Lett. 552, 145-149.

Wingertzahn, M.A., Zdanowicz, M.M., and Slonim, A.E. (1998). Insulin-like growth factor-I and high protein diet decrease calpain-mediated proteolysis in murine muscular dystrophy. Proc. Soc. Exp. Biol. Med. 218, 244-250. 
Zatz, M., Zucconi, E., Valadares, M., and Jazedje T. (2010). Phenotypes in golden retriever. Neuromuscul. 20, 71.

Zucconi, E., Valadares, M.C., Vieira, N.M., Bueno, C.R. Jr., Secco, M., Jazedje, T., Da Silva H.C., Vainzof, M., and Zatz M. (2010). Ringo: discordance between the molecular and clinical manifestation in a golden retriever muscular dystrophy dog. Neuromuscul. Disord. 2064-2070.

Zucconi, E., Vieira, N.M., Bueno, C.R. Jr., Secco, M., Jazedje, T., Costa Valadares, M., Fussae Suzuki, M., Bartolini, P., Vainzof, M., and Zatz, M. (2011). Preclinical studies with umbilical cord mesenchymal stromal cells in different animal models for muscular dystrophy. J. Biomed Biotechnol. 2011:715251.

\section{Tables and Figures}

\section{Figures Legends}

Figure 1: IGF-1 enhances the myogenic differentiation of MSCs. (A-E) Western Blot analysis of Pax-7, MyoD, Myogenin, Desmin, and Dystrophin expression in non-differentiated MSCs (control) and MSCs cultured in differentiation medium (HS; horse serum) supplemented or not with different concentrations of IGF-1 $(25 \mathrm{ng} / \mathrm{mL}$ or $50 \mathrm{ng} / \mathrm{mL})$, for 8 and 15 days. Data correspond to optical density of respective protein bands, assessed by ImageJ software. Results are expressed as percentage from control; (F) Representative Western Blot bands. Samples: 1) Non-differentiated MSCs (control); 2) MSCs cultured in differentiation medium alone (HS); 3) MSCs cultured in differentiation medium supplemented with $25 \mathrm{ng} / \mathrm{mL}$ IGF-1; 4) MSCs cultured in differentiation medium supplemented with $25 \mathrm{ng} / \mathrm{mL}$ IGF-1; (G) Representative myogenic differentiation images assessed by immunofluorescence. MSCs treated with either 25 or $50 \mathrm{ng} / \mathrm{mL}$ IGF-1 $(c, d)$ were more strongly labeled with anti-human 
Desmin and MyHC antibodies (red) than cells cultured in the absence of IGF-1 $(a, b)$. Counterstaining with DAPI (blue) was used to identify all nuclei. Scale bar $=100 \mu \mathrm{m} ; \mathbf{( H )}$ Real-time Quantitative RT-PCR analysis of MyHC (Myosin Heavy Chain) in non-differentiated MSCs (control) or MSCs cultured in differentiation medium (HS) supplemented or not with different concentrations of IGF-1 ( $25 \mathrm{ng} / \mathrm{mL}$ or $50 \mathrm{ng} / \mathrm{mL})$, for 8 and 15 days. The number of cell lines analyzed in each group is shown in parentheses and the data are presented as mean $\pm \mathrm{SE}$. ${ }^{*} \mathrm{P}<0.05$ versus MSCs cultured in HS; Student's $t$ test.

Figure 2: IGF-1 enhances the interaction between MSCs and DMD muscle cells and restores the dystrophin expression. (A) Schematic representation of co-culture experiments; (B) Images from fluorescence microscopy show the GFP-positive (green) MSCs (a) and DAPI (blue) DMD muscle cells (b), before the experiments. After 45 days of co-culture, interaction between Mesenchymal Stromal Cells (MSCs) and Duchenne Muscular Dystrophy (DMD) muscle cells was confirmed by the presence of DAPI/GFP ${ }^{+}$myotubes (c-e). Arrows indicate the nuclei of a DAPI/GFP ${ }^{+}$myotubes (c-e); (C) Western Blot analysis of Dystrophin expression; First Line: Co-culture of $\underline{\text { myoblasts }}$ with MSCs, maintained in differentiation medium supplemented or not with IGF-1; Second Line: Co-culture of myotubes with MSCs, maintained in proliferation medium supplemented or not with IGF-1; Samples: 1) GFP-positive MSCs; 2) DMD muscle cells; 3) DMD muscle cells culture in medium supplemented with IGF-1; 4) Co-culture of MSCs with DMD muscle cells; 5) Co-culture of MSC with DMD muscle cells maintained in medium supplemented with IGF-1; 6) Normal muscle cells ; 7) Normal muscle cells culture in medium supplemented with IGF-1; 8) 
Co-culture of MSCs with normal muscle cells; 9) Co-culture of MSCs with normal muscle cells maintained in medium supplemented with IGF-1.

Figure 3: Association of IGF-1 and MSCs improves skeletal muscular strength in LAMA2 ${ }^{d y / 2 j}$ dystrophic mice. (A) Grip Force indicated as performance variation before and after the treatments $(\mathbf{B}, \mathbf{C})$ Muscle Twitch and Tetanic Force determined at $1 \mathrm{~Hz}$ and $250 \mathrm{~Hz}$ of electrical stimulus frequency, respectively, in untreated dystrophic mice $(\mathrm{U} ; \mathrm{n}=11)$, IGF-1 treated mice (IGF-1; $\mathrm{n}=9$ ), MSC treated mice (MSC; $n=13$ ) and both IGF-1 and MSC treated mice (IGF-1+MSC; n=13). Twitch and Tetanic Forces were normalized to body mass. Data are presented as mean $\pm \mathrm{SE}$. ${ }^{*} \mathrm{P}<0.05$; Student's $t$ test.

Figure 4: MSCs from UC injected systemically in dystrophic mice were able to reach the skeletal muscle but did not differentiate into muscle cells, even when associated with IGF-1. (A) PCR analysis for human chromosome 7 a-satellite sequences $(\mathrm{H} 7)$ or endogenous sequence (Endogenous) in the Tibialis Anterior (TA) muscle from untreated and treated mice. (B) Western blot analysis of human dystrophin in TA muscle from mice. Samples: 1) Untreated dystrophic mice; 2) IGF-1 treated mice; 3) MSC treated mice; 4) IGF-1+MSC treated mice; 5) Non-dystrophic mice (control-CNT); H) Human DNA or protein, used as a positive control.

Figure 5: Association of both MSCs and IGF-1 reduces fibrosis in LAMA2 $^{\text {dy/2j }}$ dystrophic muscle. (A) Representative H\&E and Picro-sirius Redstained cross sections of Tibialis Anterior (TA) muscle from untreated or treated mice; (B-E) Diagram showing the quantitative analysis of Cross-Sectional Area, Centronucleated Fibers, Interstitium and Fibrotic Area percentage (C,D,E); (F-H) 
Real-time Quantitative RT-PCR analysis of Col1a1, Col3a1, and TGF- $\beta$ expression in muscle samples from untreated dystrophic mice (U), IGF-1 treated mice (IGF-1), MSC treated mice (MSC), both IGF-1 and MSC treated mice (IGF1+MSC), in comparison with non-dystrophic mice (control; CNT) expression; (I) Western Blot analysis of TGF- $\beta$ expression in muscle samples from untreated and treated mice, compared with the control (CNT). Data correspond to optical density of respective protein bands, assessed by ImageJ software; (J) Representative Western Blot bands. Samples: 1) Untreated dystrophic mice; 2) IGF-1 treated mice; 3) MSC treated mice; 4) IGF-1+MSC treated mice; 5) Nondystrophic mice (CNT). The number of animals analyzed in each group is shown in parentheses and the data are presented as mean $\pm \mathrm{SE}$. ${ }^{*} \mathrm{P}<0.05$; Student's $t$ test.

Figure 6: Association of both MSCs and IGF-1 modulates inflammation through reduction of inflammatory molecules in skeletal muscle of LAMA2 $^{\text {dy/2j }}$ dystrophic model. (A) Western Blot analysis of TNF- $\alpha$ expression in muscle samples from untreated dystrophic mice (U), IGF-1 treated mice (IGF1), MSC treated mice (MSC), both IGF-1 and MSC treated mice (IGF-1+MSC), in comparison with non-dystrophic mice (control; CNT) expression. Data correspond to optical density of respective protein bands, assessed by ImageJ software; (B) Representative Western Blot bands. Samples: 1) Untreated dystrophic mice; 2) IGF-1 treated mice; 3) MSC treated mice; 4) IGF-1+MSC treated mice; 5) Non-dystrophic mice (CNT); (C-G) Real-time Quantitative RTPCR analysis of CCL2, CCL8, CCL5, CCL3, and IkB- $\alpha$ expression in muscle samples of untreated and treated mice, compared with control. The number of 
animals in each group is shown in parentheses and the data are presented as mean \pm SE. ${ }^{*} \mathrm{P}<0.05$; Student's $t$ test.

Figure 7: Association of both MSCs and IGF-1 contributes to the regeneration process in Lama2 ${ }^{d y / 2 j}$ dystrophic muscle. (A-C) Western Blot analysis of Pax-7, MyoD and Myogenin expression in muscle samples from untreated dystrophic mice (U), IGF-1 treated mice (IGF-1), MSC treated mice (MSC), both IGF-1 and MSC treated mice (IGF-1+MSC), in comparison with non-dystrophic mice (control; CNT) expression. Data correspond to optical density of respective protein bands, assessed by ImageJ software; (D) Representative Western Blot bands. Samples: 1) Untreated dystrophic mice; 2) IGF-1 treated mice; 3) MSC treated mice; 4) IGF-1+MSC treated mice; 5) Nondystrophic mice (CNT); (E-G) Real-time Quantitative RT-PCR analysis of Myf5, MyoD and Myogenin expression in muscle samples of untreated and treated mice, compared with control. The number of animals in each group is shown in parentheses and the data are presented as mean $\pm \mathrm{SE}$. ${ }^{*} \mathrm{P}<0.05$; Student's $t$ test.

Figure 8: Association of both MSCs and IGF-1 affects expression of proteins related with proteolytic systems in muscle of LAMA2 ${ }^{\text {dy/2j }}$ dystrophic model. (A-D) Western Blot analysis of MuRF1, Calpain-1, Calpain2, and Calpastatin in muscle samples from untreated dystrophic mice (U), IGF-1 treated mice (IGF-1), MSC treated mice (MSC), both IGF-1 and MSC treated mice (IGF-1+MSC), in comparison with non-dystrophic mice (control; CNT) expression. Data correspond to optical density of respective protein bands, assessed by ImageJ software; (E) Representative Western Blot bands. 
Samples: 1) untreated dystrophic mice; 2) IGF-1 treated mice; 3) MSC treated mice; 4) IGF-1+MSC treated mice; 5) Non-dystrophic mice (CNT). The number of animals in each group is shown in parentheses and the data are presented as mean $\pm \mathrm{SE}$. ${ }^{*} \mathrm{P}<0.05$; Student's $t$ test.

Figure 9: Association of both MSCs and IGF-1 do not change calcium handling protein expression in the muscle of LAMA2 ${ }^{d y / 2 j}$ dystrophic model. $(A, B)$ Western Blot analysis of NCX and SERCA1 in muscle samples from untreated dystrophic mice (U), IGF-1 treated mice (IGF-1), MSC treated mice (MSC), both IGF-1 and MSC treated mice (IGF-1+MSC), in comparison with non-dystrophic mice (control; CNT) expression. Data correspond to optical density of respective protein bands, assessed by ImageJ software; (C) Representative Western Blot bands. Samples: 1) untreated dystrophic mice; 2) IGF-1 treated mice; 3) MSC treated mice; 4) IGF-1+MSC treated mice; 5) Nondystrophic mice (CNT). The number of animals in each group is shown in parentheses and the data are presented as mean $\pm \mathrm{SE}$. ${ }^{*} \mathrm{P}<0.05$; Student's $t$ test. 
TABLE 1. Primer Sequences for Human DNA Analysis and Real-time Quantitative RT-PCR

\begin{tabular}{ccc}
\hline Gene & Forward Primer Sequence (5'-3') & Reverse Primer Sequence (5'-3') \\
\hline H7 & AGCGATTTGAGGACAATTGC & CCACCTGAAAATGCCACAGC \\
Endogenous & AAATGCGGCACATCAGTTTT & TAAGCTGGAGAGACGGTGCT \\
Human Dystrophin & GAATAAGTCAGTGACCCAGAAGAC & TGGTGACAGCCTGTGAAAC \\
COI1a1 & GATGGTCACCCTGGAAAACC & CACGAGCACCCTGTGGTCC \\
Col3a1 & AACCTGGAAGGGATGGAAAC & GCACCAGGAGAACCATTTC \\
TGF- $\beta$ & CCCCACTGATACGCCTGAGT & AGCCCTGTATTCCGTCTCCTT \\
CCL2 & GGCTCAGCCAGATGCAGTTA & GCTGCTGGTGATCCTCTTGT \\
CCL8 & CTGGGCCAGATAAGGCTCC & CATGGGGCACTGGATATTGTT \\
CCL5 & ATATGGCTCGGACACCACTC & GCACTTGCTGCTGGTGTAGA \\
CCL3 & CGCCATATGGAGCTGACAC & GATGAATTGGCGTGGAATCT \\
IKB- $\alpha$ & AGACTCGTTCCTGCACTTGG & AAGTTGAGGAAGGCCAGGTC \\
Myf5 & CTGTCTGGTCCCGAAAGAAC & GACGTGATCCGATCCACAATG \\
MyoD & TACAGTGGCGACTCAGATGC & TAGTAGGCGGTGTCGTAGCC \\
Myogenin & CAGTACATTGAGCGCCTACAG & GGACCGAACTCCAGTGCAT \\
GAPDH & AGGTCGGTGTGAACGGATTTG & TGTAGACCATGTAGTTGAGGTCA \\
& & \\
\hline
\end{tabular}


TABLE 2. Basic Parameters of dystrophic LAMA2 $2^{d y / 2 j}$ mice after treatment with IGF-1 and MSC

\begin{tabular}{|c|c|c|c|c|c|}
\hline & $\begin{array}{l}\text { Untreated } \\
\qquad(n=7)\end{array}$ & $\begin{array}{l}\text { IGF-1 } \\
(n=8)\end{array}$ & $\begin{array}{l}\text { MSC } \\
(n=8)\end{array}$ & $\begin{array}{c}\text { IGF-1+MSC } \\
(n=8)\end{array}$ & $\begin{array}{c}\text { Control } \\
(n=7)\end{array}$ \\
\hline Body mass (g) & $20.61 \pm 0.70$ & $19.88 \pm 0.30$ & $18.98 \pm 0.39^{*}$ & $20.73 \pm 0.84$ & $25.34 \pm 0.78^{* *}$ \\
\hline TA mass/body mass $(\mathrm{mg} / \mathrm{g})$ & $1.47 \pm 0.05$ & $1.40 \pm 0.04$ & $1.47 \pm 0.05$ & $1.46 \pm 0.04$ & $1.90 \pm 0.03^{* *}$ \\
\hline Heart mass/body mass $(\mathrm{mg} / \mathrm{g})$ & $4.97 \pm 0.12$ & $5.23 \pm 0.12$ & $5.16 \pm 0.28$ & $5.27 \pm 0.18$ & $4.60 \pm 0.13^{* *}$ \\
\hline Liver mass/body mass $(\mathrm{mg} / \mathrm{g})$ & $52.55 \pm 1.87$ & $55.96 \pm 2.58$ & $55.35 \pm 2.03$ & $53.41 \pm 2.64$ & $45.79 \pm 1.49^{* *}$ \\
\hline Glucose (mg/dL) & $132.04 \pm 35.68$ & $171.08 \pm 27.69$ & $204.97 \pm 28.88$ & $180.10 \pm 36.45$ & $205.23 \pm 28.19$ \\
\hline Triglycerides (mg/dL) & $157.86 \pm 23.31$ & $128.90 \pm 13.03$ & $159.13 \pm 37.83$ & $126.06 \pm 14.74$ & $117.07 \pm 12.71$ \\
\hline Cholesterol (mg/dL) & $101.15 \pm 7.50$ & $102.57 \pm 6.48$ & $90.22 \pm 7.73$ & $83.53 \pm 4.98^{* * *}$ & $93.80 \pm 6.27$ \\
\hline
\end{tabular}

The number of animals in each group is shown in parentheses and the data are presented as mean \pm SE. Tibialis Anterior (TA), heart and liver mass was normalized to body mass. ${ }^{*} \mathrm{P}<0.05$ versus untreated group; ${ }^{* *} \mathrm{P}<0.05$ versus untreated and treated $\mathrm{LAMA} 2^{d y / 2 j}$ dystrophic mice; ${ }^{* *} \mathrm{P}<0.05$ versus untreated and IGF-1 treated mice; Student's $t$ test. 
FIGURE 1

A

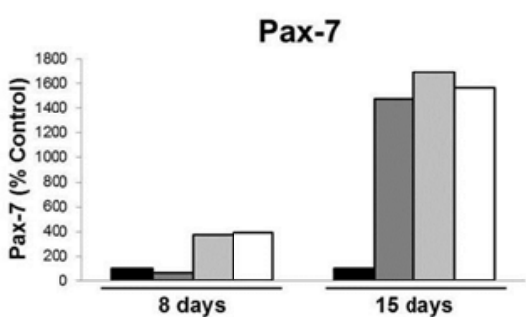

C

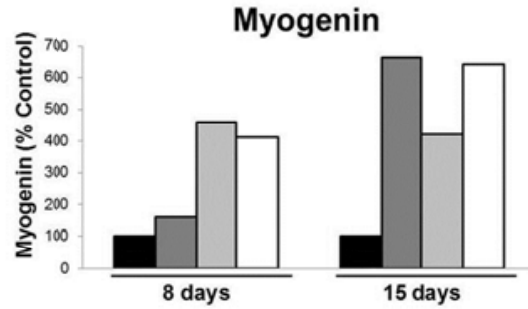

E

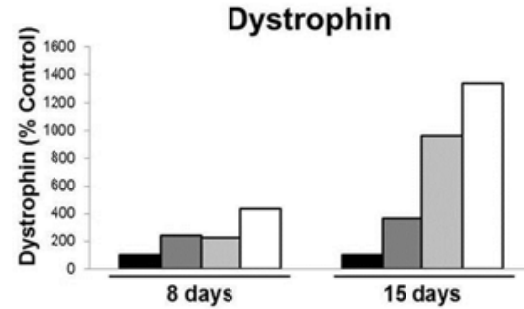

B

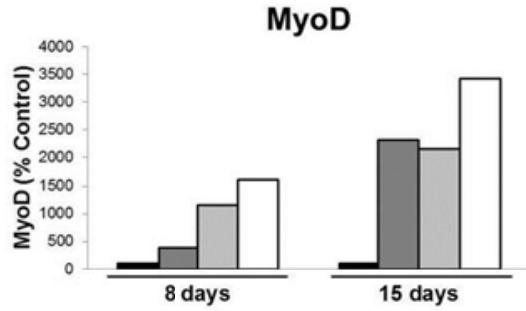

D

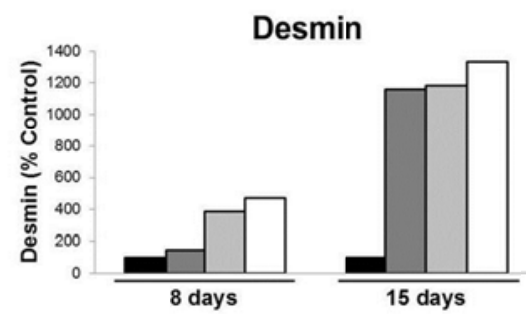

$\mathbf{F}$

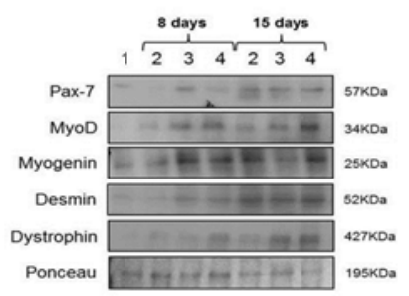

aControl ㅁHS ㅁIGF $25 \mathrm{ng} / \mathrm{mL}$ ㅁIGF $50 \mathrm{ng} / \mathrm{mL}$

G

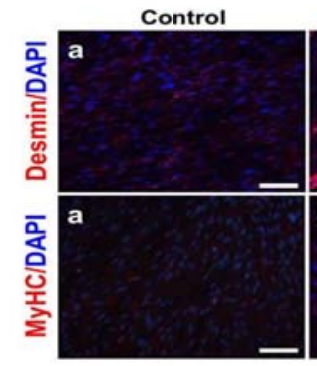

HS

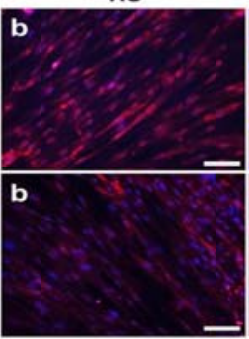

IGF $25 n g / m L$

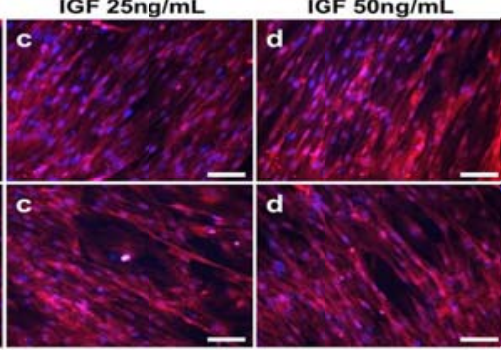

H

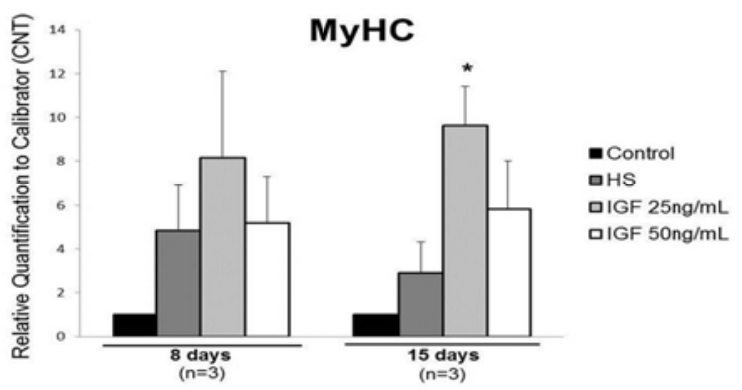




\section{FIGURE 2}

A

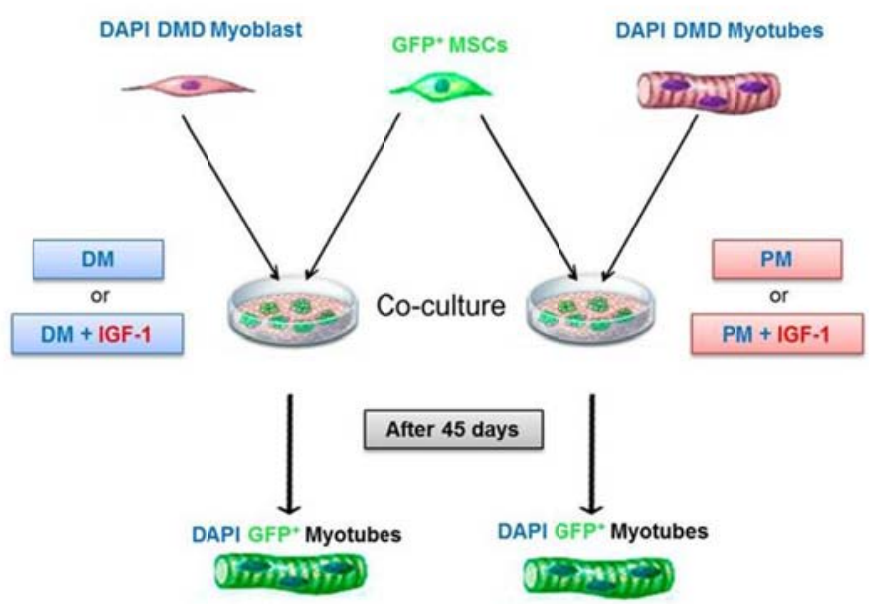

B
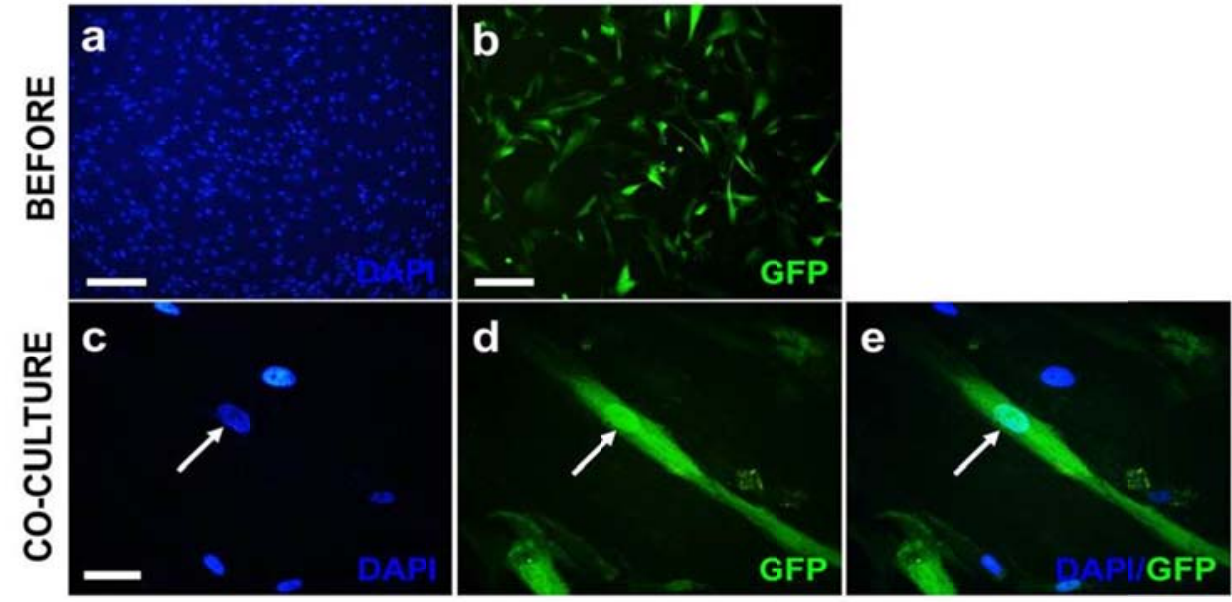

C

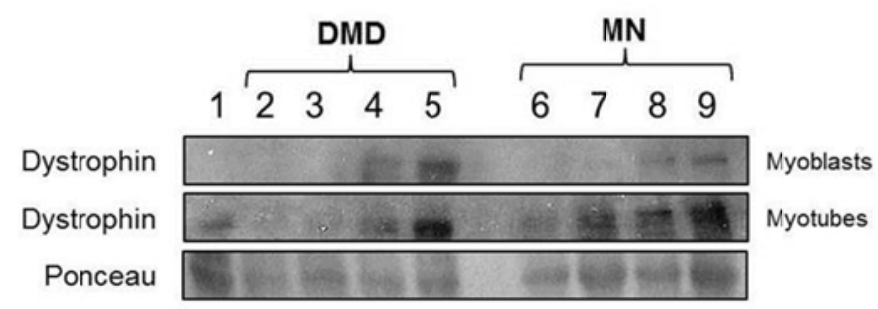


FIGURE 3

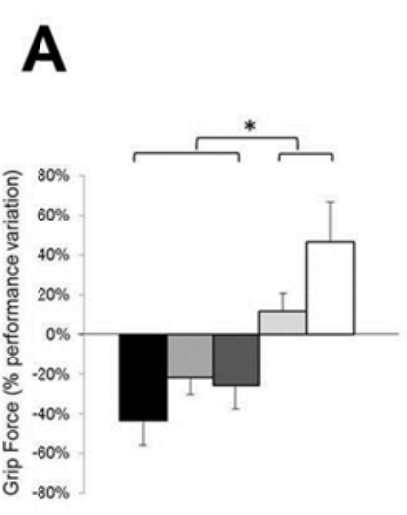

B

C
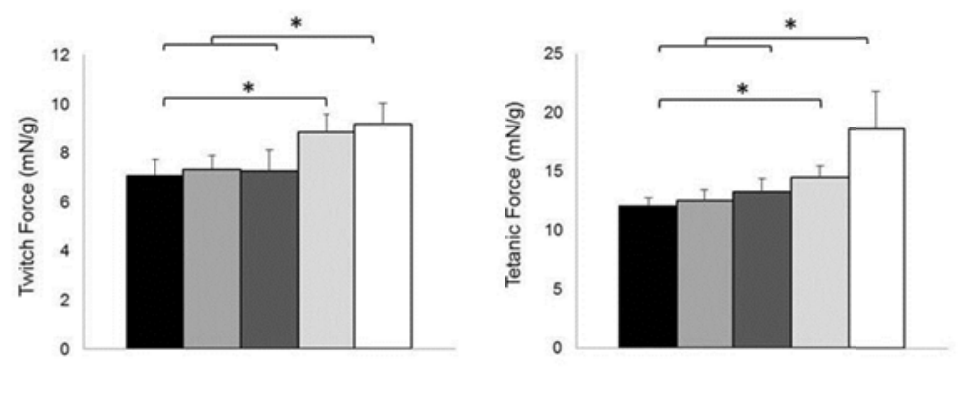

घU घIGF-1 घMSC 口IGF+MSC 口CNT

\section{FIGURE 4}

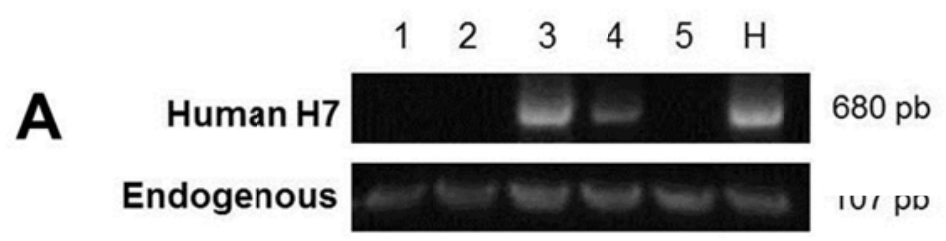

B

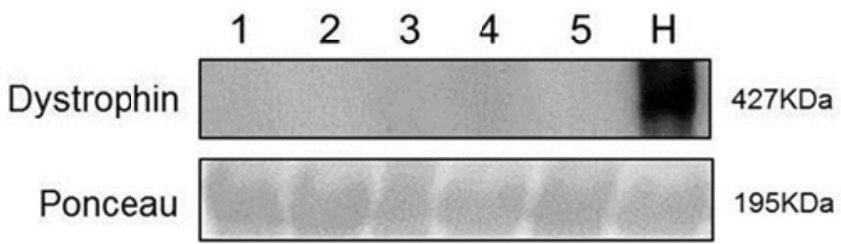




\section{FIGURE 5}
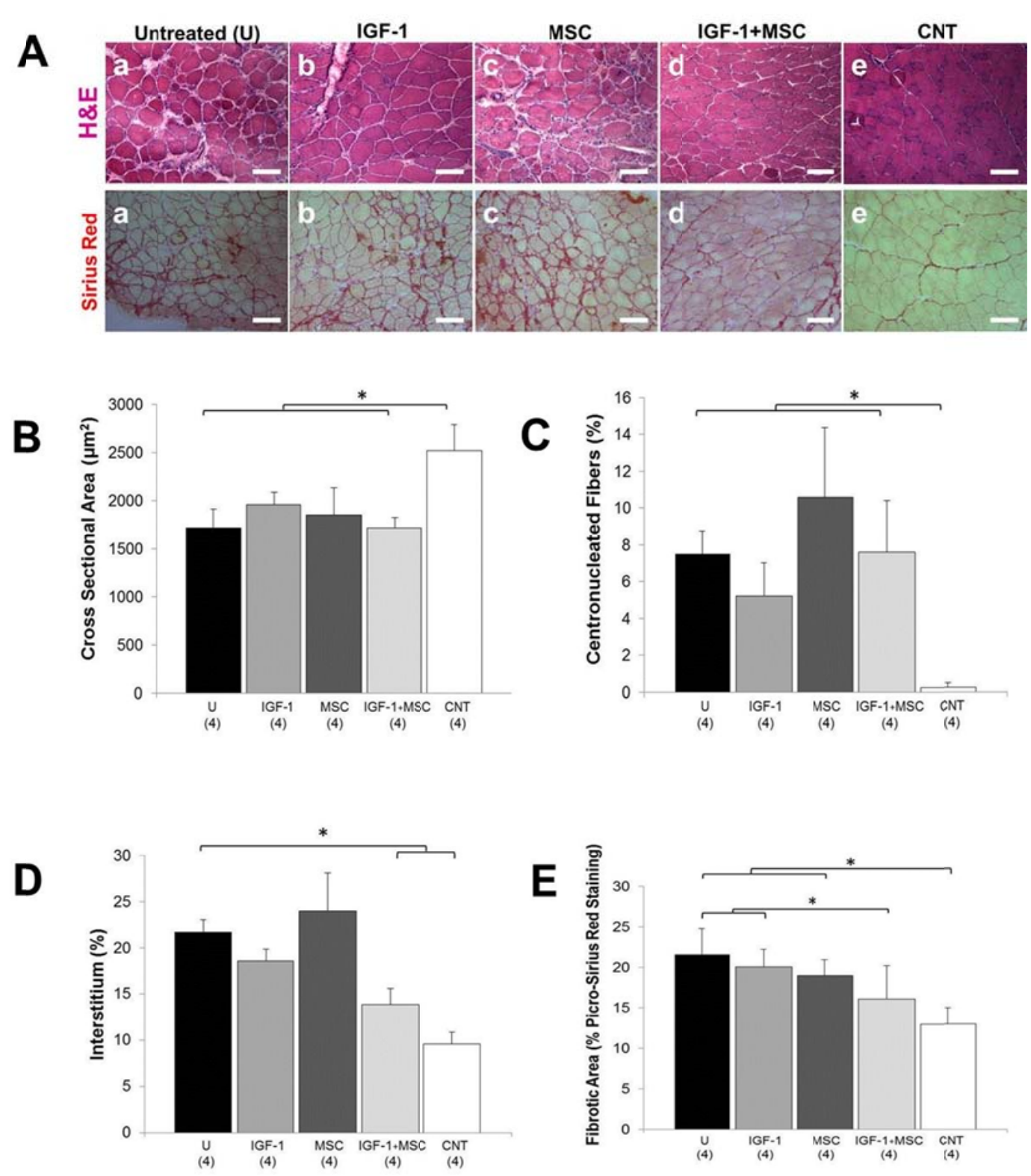


\section{FIGURE 5}
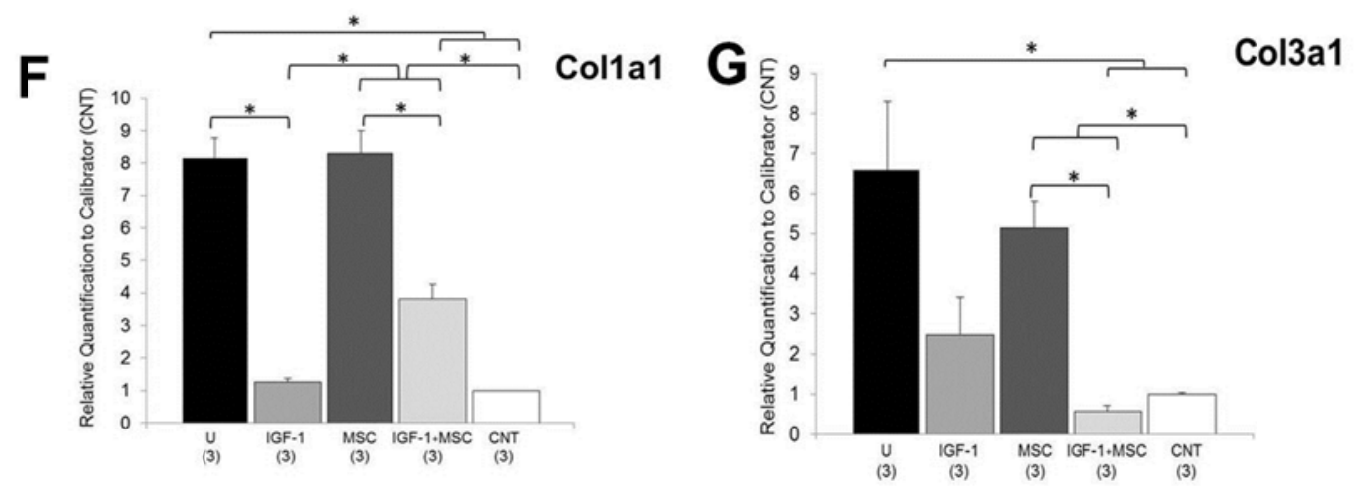

H

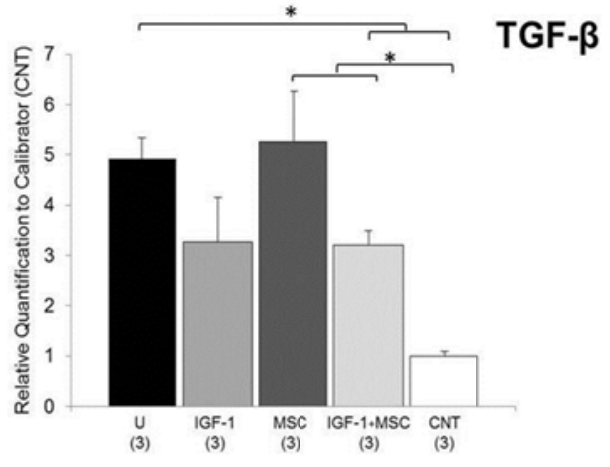

I

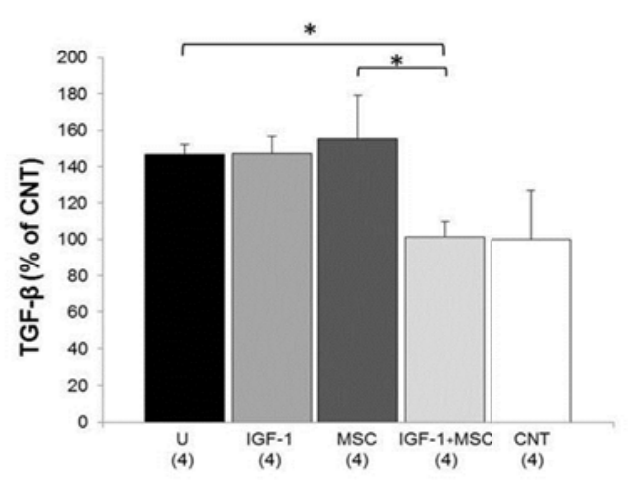

J

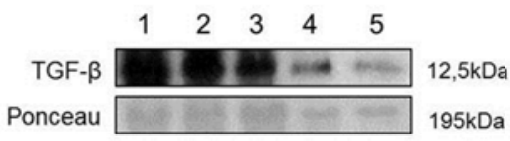




\section{FIGURE 6}

A

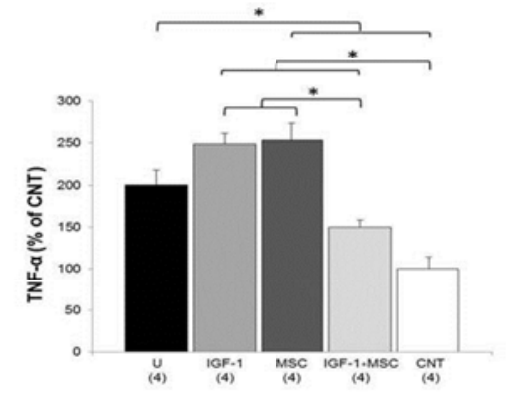

C

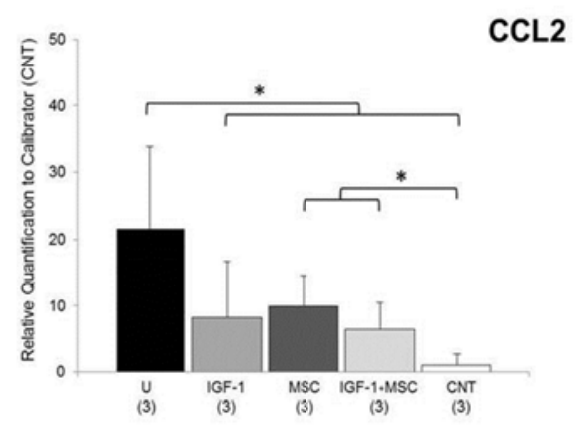

E
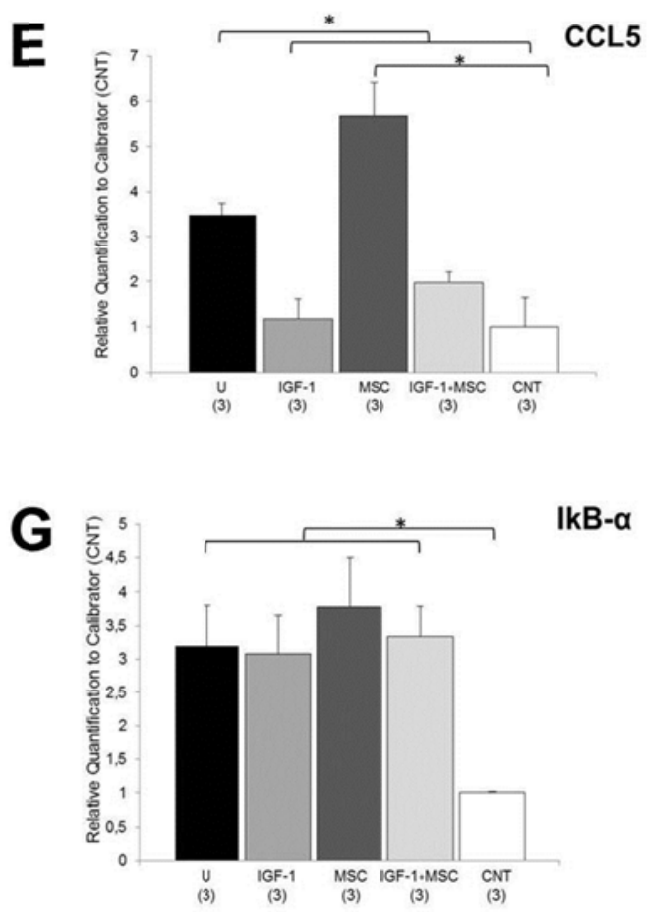

B

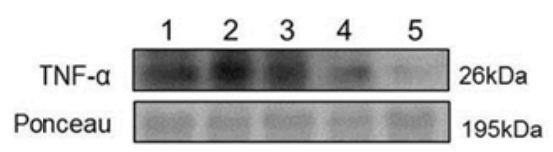

D

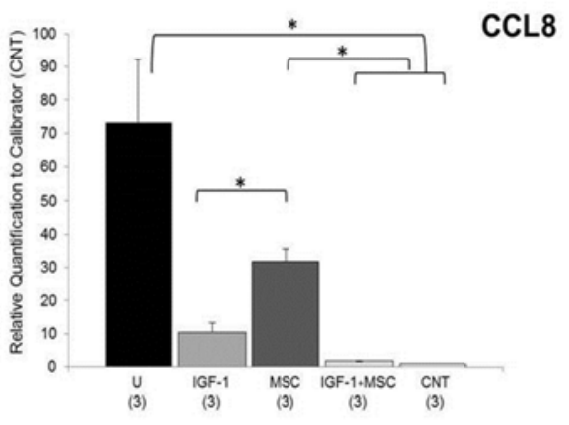

F

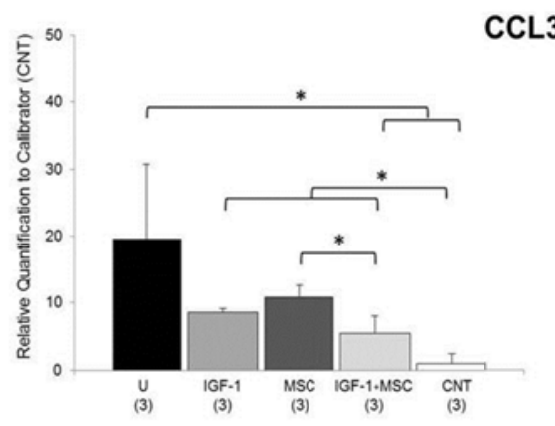




\section{FIGURE 7}
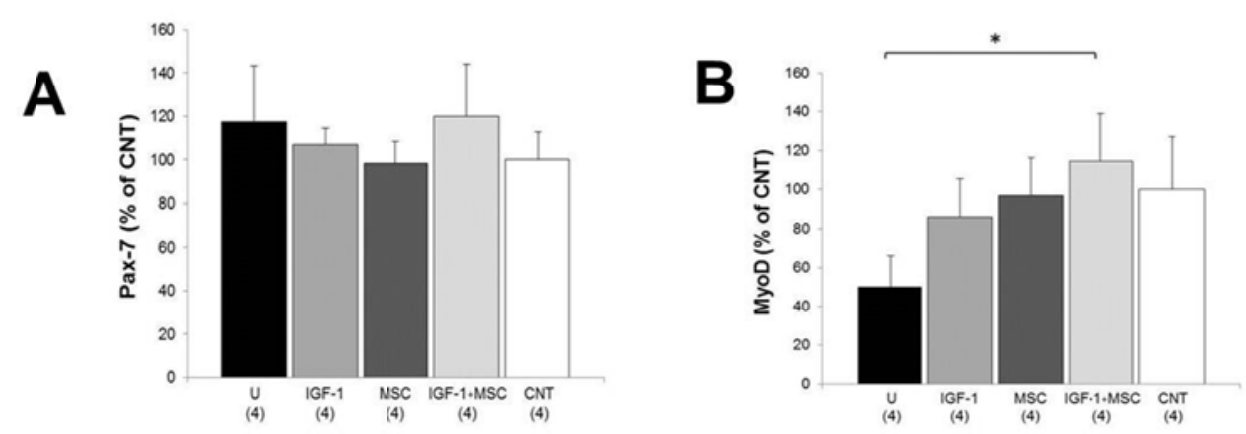

C

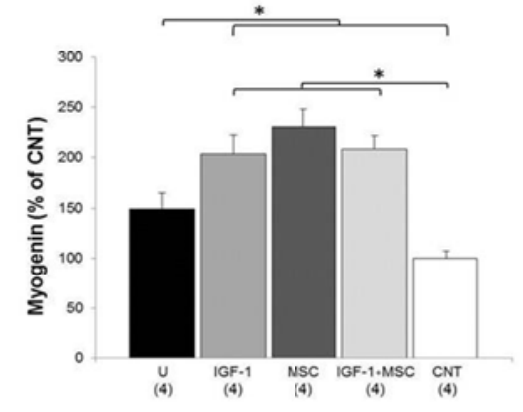

E

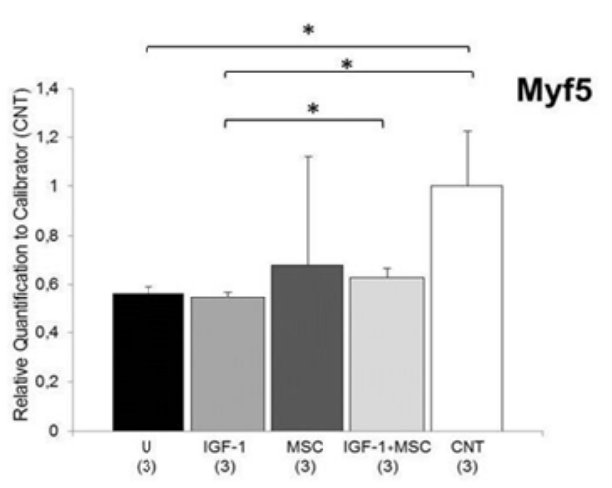

G

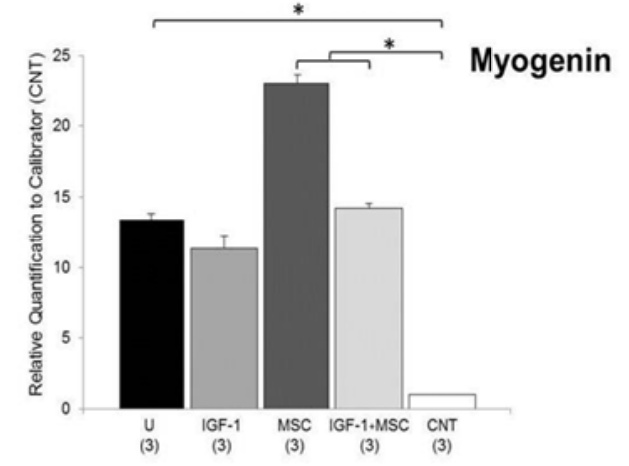

D

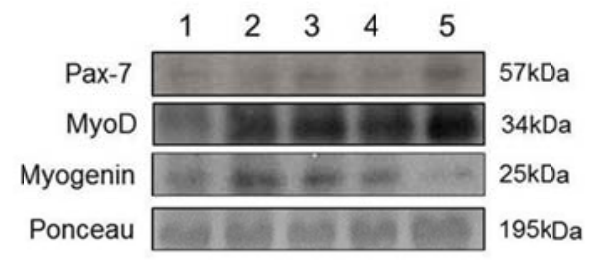

F

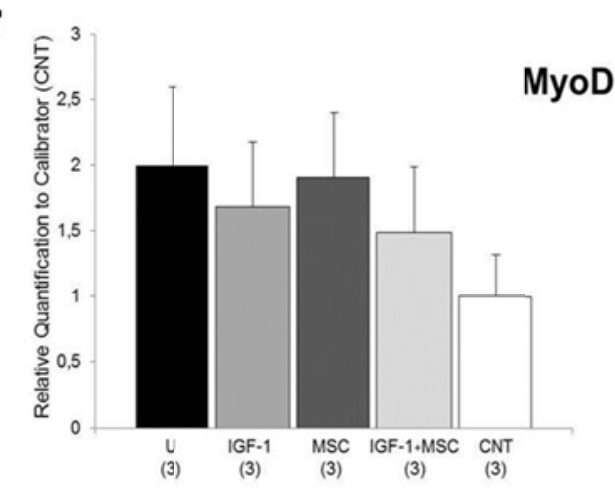


FIGURE 8

A

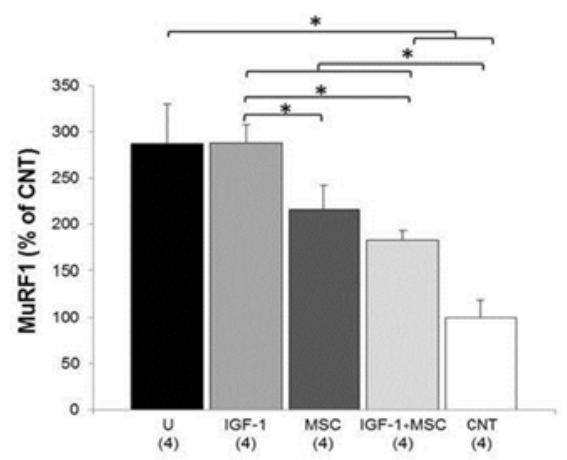

C

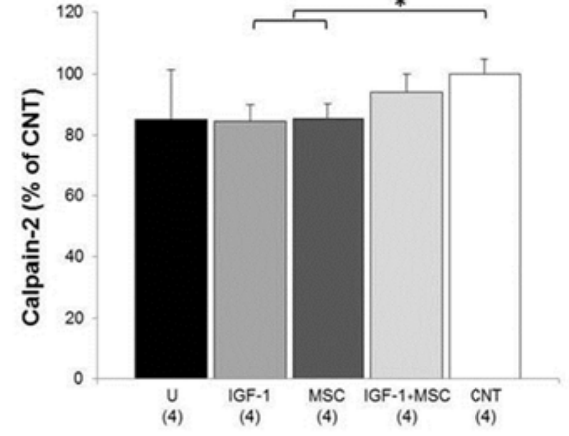

B

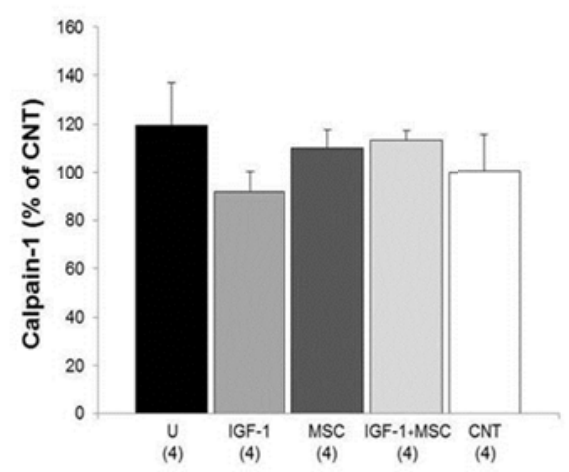

D

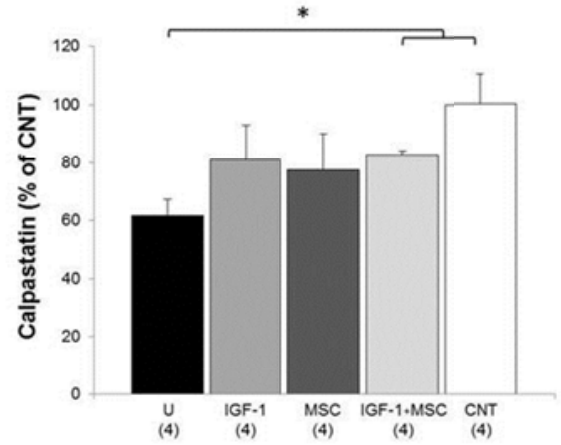

E

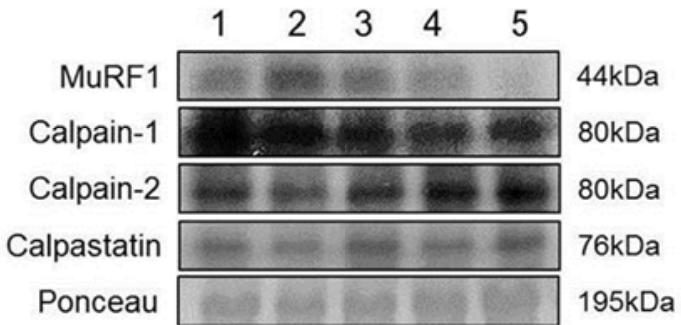


FIGURE 9

A

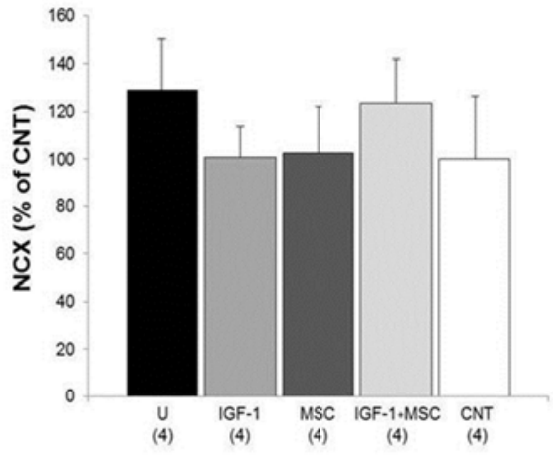

B

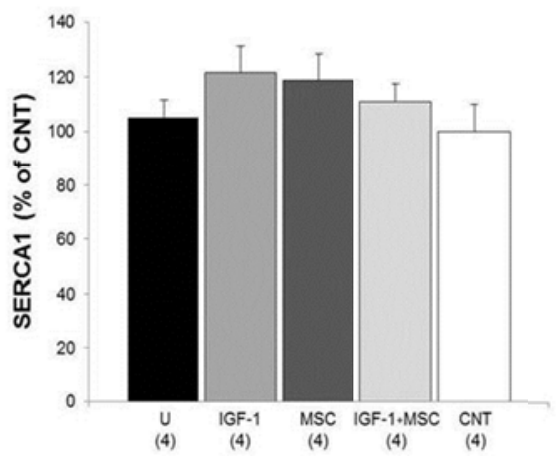

C

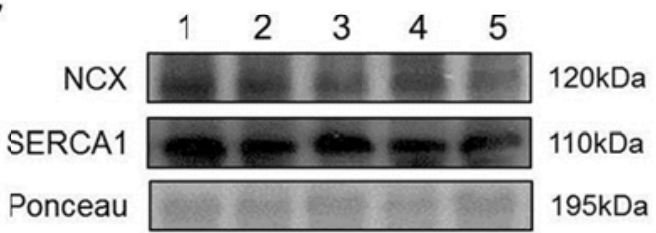




\section{Capítulo 6}

\section{ADMINISTRAÇÃO LOCAL DE IGF-1, EM ASSOCIAÇÃO A CÉLULAS-TRONCO MESENQUIMAIS HUMANAS, EM UM MODELO MURINO DE DISTROFIA MUSCULAR}

Artigo em preparação para submissão - Outubro de 2011

Evaluation of intramuscular injections of IGF-1 associated with mesenchymal stromal cells in a murine model of congenital muscular dystrophy

Mariane Secco, Carlos Bueno Júnior, Natassia M. Vieira, Camila Almeida, Mayra Pelatti, Elen H. Miyabara, Mariz Vainzof, Oswaldo K. Okamoto, Mayana Zatz. 


\section{ABSTRACT}

Progressive muscular dystrophies (PMDs) are a group of inherited disorders characterized by muscle weakness and wasting. Although several promising experimental strategies are emerging, currently there is no effective therapy for these conditions. Recently, we reported that the association of both IGF-1 recombinant protein and mesenchymal stromal cells (MSCs), systemically administrated, markedly improved muscle strength in LAMA2 ${ }^{d y / 2 j}$ dystrophic mice - a murine model of congenital muscular dystrophy. Here we demonstrated that, in opposition to our previous results, intramuscular injections of IGF-1 did not result in functional improvement of LAMA $2^{\text {dy/2j }}$ dystrophic muscle, even when associated to MSCs. This finding suggests that IGF-1 should be delivered systemically in association with MSCs, to promote a more effective muscle functional recovery in murine models for muscular dystrophy. 


\section{RESUMO}

As Distrofias Musculares constituem um grupo de doenças genéticas caracterizadas por degeneração progressiva e irreversível da musculatura esquelética. Atualmente nenhum tratamento efetivo se encontra disponível para os diferentes tipos de distrofias musculares. No entanto, diversas abordagens terapêuticas têm sido investigadas. Recentemente nós demonstramos que a associação de células estromais mesenquimais ao fator de crescimento IGF-1, sistemicamente administrados, foi capaz de melhorar significativamente a força muscular de camundongos distróficos LAMA2 ${ }^{\text {dy/2j }}$ - um modelo murino para a Distrofia Muscular Congênita tipo 1A. Ao contrário dos resultados previamente reportados, aqui nós mostramos que injeções intramusculares de IGF-1 não resultaram em melhora clínica funcional do músculo de camundongos LAMA2 $^{d y / 2 j}$, mesmo quando em associação a MSCs. Em conjunto, esses dados reforçam a superioridade de métodos terapêuticos sistêmicos, sobretudo nos casos de distrofias musculares. 
Brief Article

\title{
Evaluation of intramuscular injections of IGF-1 associated with mesenchymal stromal cells in a murine model of congenital muscular dystrophy
}

\author{
Mariane Secco ${ }^{1}$, Carlos Bueno Júnior ${ }^{1}$, Natassia M. Vieira , Camila Almeida ${ }^{1}$, \\ Mayra Pelatti , Elen H. Miyabara ${ }^{1}$, Mariz Vainzof ${ }^{1}$, Oswaldo K. Okamoto ${ }^{1}$, \\ Mayana Zatz ${ }^{1 \dagger}$ \\ 1 \\ Human Genome Research Center, Department of Genetic and Evolutive \\ Biology, University of São Paulo, São Paulo, Brazil. \\ 2 \\ Department of Anatomy, Institute of Biomedical Sciences, University of São \\ Paulo, São Paulo, Brazil.
}

\section{Keywords}

Human mesenchymal stromal cells, umbilical cord, IGF-1, local delivery, muscular dystrophy therapy

${ }^{\dagger}$ Address correspondence to: Mayana Zatz, mayazatz@usp.br

Centro de Estudos do Genoma Humano, Departamento de Genética e Biologia Evolutiva, Universidade de São Paulo, São Paulo, SP, Brazil.

Rua do Matão, 106 - Cidade Universitária, 05508-090 São Paulo, SP, Brasil

Phone / fax number: (55) (11) 3091-7966

\section{Research support}

This work was supported by grants from CEPID-FAPESP (Centro de Pesquisa, Inovação e Difusão-Fundação de Amparo a Pesquisa do Estado de São Paulo), CNPq (Conselho Nacional de Desenvolvimento Científico e Tecnológico) and INCT (Instituto Nacional de Ciência e Tecnologia). 


\section{Brief Article}

Mesenchymal stromal cells (MSCs) have emerged as leading candidates for regenerative treatment of many diseases, including muscular dystrophies (Kerkis et al., 2008; Vieira et al., 2008; Gang et al., 2009; Ichim et al.,2010; Vieira et al., 2010; Vieira et al., 2011). Several research groups have attempted to optimize MSC-based therapeutics, aiming to successful clinical application (Wagner et al., 2009; Quattrocelli et al., 2010). We recently reported that the association of IGF-1 recombinant protein and MSCs, systemically administrated, markedly reduced muscle inflammation and fibrosis, and significantly improved muscle strength in LAMA2 $2^{d y / 2 j}$ dystrophic mice, a murine model for congenital muscular dystrophy (Secco et al., submitted).

Regarding the route of administration, our group has previously demonstrated that systemic delivery of human MSCs in golden retriever muscular dystrophy (GRMD) dogs are more effective than MSCs muscle local injections (Kerkis et al., 2008; Vieira et al., 2011). However, it is not known if IGF-1 recombinant protein, in association with systemic MSCs delivery, is more effective when administrated systemically or locally. Previous studies have demonstrated that, IGF-1 administrated directly into muscle is able to activate intracellular signals involved in muscle hypertrophy and promote the muscle functional amelioration, in a muscle injury model induced by myotoxin (Schertzer and Lynch, 2006). Other study demonstrated that IGF-1 intramuscular injections contribute to muscle repair by the recruitment of progenitor cells-derived from bone marrow to damaged muscles (Sacco et al., 2005). Li et al. (2007) also showed that IGF-1 enhances the migratory capacity of MSCs in vitro. Taking into account these findings, here we investigated whether IGF-1 administrated 
locally into muscle is capable to enhance MSCs homing to damaged skeletal muscle and, consequently, improve cell transplantation success in a dystrophic murine model.

In order to address this question, we analyzed, for the first time, the effects of IGF-1 administration directly into muscle, in combination with MSCs systemically delivered, in LAMA2 ${ }^{d y / 2 j}$ dystrophic mice.

In opposition to our previous results observed with IGF-1+MSCs systemic delivery, intramuscular injections of IGF-1 did not result in significant functional improvements of muscular strength of LAMA2 ${ }^{d y / 2 j}$ dystrophic mice, even when associated to MSCs (FIGURE 1). In addition, as summarized in TABLE 1, continuous local administration of IGF-1 protein for 8 weeks, MSC injections alone or the association of both approaches did not alter morphometric properties of injected animals, such as body, heart and liver mass, in comparison to untreated dystrophic LAMA2 ${ }^{d y / 2 j}$ mice. Moreover, IGF-1 local delivery into muscle did not cause muscle hypertrophy, as evidenced by unchanged Tibialis Anterior (TA) muscle mass and fibers cross-sectional area (CSA), in comparison to untreated dystrophic mice (FIGURE 2).

It is has been suggested that myofiber hypertrophy is not crucial for a significant muscle functional amelioration. Corroborating with this observation, our previous study (Secco et al., submitted) described a functional recovery in dystrophic animals treated systemically with IGF-1+MSC regardless of muscle hypertrophy. On the other hand, the effects of IGF-1 on muscle repair seem to be strongly related with the modulation of the inflammatory response, and the reduction of fibrosis (Pelosi et al., 2007). Here we showed that the 
association of locally administrated IGF-1 and MSCs did not change the amount of inflammation neither interstitial fibrosis, as evidenced by the unchanged interstitium percentage in comparison to untreated animals (FIGURE 2). This finding might explain why there was no significant functional improvement of muscular strength in the treated animals. In addition, curiously, we observed a significant decrease in tetanic force of $L A M A 2^{d y / 2 j}$ dystrophic muscle that received vehicle solution injections (FIGURE 1C). This data indicate that successive injections into skeletal muscle can provoke an additional muscle damage, which could to be accounting the negative results regarding the functional muscle amelioration.

Although previous studies have showed encouraging results regarding muscle local delivery of IGF-1 on muscle repair (Schertzer and Lynch et al., 2006; Sacco et al., 2005), these studies were done in a different animal model. Schertzer and Lynch (2006) used a mouse model of muscle damage induced by myotoxin, which has an inflammatory process much milder than the LAMA $2^{d y / 2 j}$ dystrophic mice. Moreover, the damage is restricted to only a Tibialis Anterior muscle and does not involve the entire body musculature as in muscular dystrophy mice. Although we cannot rule out the possibility that successive local injections might trigger a different reaction against injected cells than systemic delivery our results suggest that the systemic administration of IGF-1+MSCs, is the best choice to promote muscle functional recovery in murine models for muscular dystrophy.

Since a significant obstacle in designing a therapy for PMDs is the requirement to reach the entire body musculature, our results in different animal models indicate that systemic delivery would be more efficient. Studies aiming to 
analyze the best route for stem cells homing are extremely important to design therapeutic clinical protocols for several diseases, including muscular dystrophies.

\section{EXPERIMENTAL PROCEDURES}

All experiments were approved by the research ethics committee of the Biosciences Institute, University of São Paulo.

MSCs from human umbilical cord tissue were isolated and characterized using methods previously described (Secco et al., 2008, 2009). A cohort of 42 one-month old B6.WK-Lama2 ${ }^{\text {dy/2J }}$ dystrophic mice (Jackson Laboratory) was randomly assigned into four experimental groups: untreated group (U; n=11), MSCs group (MSC; n=13), local IGF-1-treated group (IGF-1; $n=9$ ), and group treated with both local IGF-1 and MSC (local IGF-1+MSC; $n=9$ ). Age-matched B6.WK non-dystrophic mice were used as wild-type controls (CNT; $n=21) .1 \times 10^{6}$ human MSCs from umbilical cord were systemically injected in the tail vein of B6.WK-Lama2 ${ }^{d y / 2 J}$ dystrophic mice, once per week during 8 weeks. The analog recombinant human IGF-1 (Long R3-IGF-1; Sigma-Aldrich) was injected into Tibialis Anterior (TA) muscle (10 $\mathrm{\mu g}$ in 25uL) on the same days of MSCs transplantations. As control, vehicle solution alone was injected into the contralateral leg (vehicle). The muscle functional performance was analyzed one week after the last injection.

To verify whether the locally administrated IGF-1 combined with MSCs, would improve motor ability in LAMA2 ${ }^{d y / 2 j}$ injected mice, we evaluated 
the grip force before and after the treatments. For this purpose, animals were allowed to grab onto the Grip Strength System (model: DFE-002, San Diego Instruments, San Diego, Cal, USA) with each hind paws separately, which measures the maximal force before the animal releases the paws of the bar. In order to confirm these results, we performed tests to measure the muscle contractile properties of the animals, according to protocols previously published. In brief, mice were anesthetized with pentobarbitone sodium (Nembutal,Rhone Merieux, Pinkenba) with supplemental doses administered in order to prevent all responses to tactile stimuli. TA muscles from animal models were stimulated by supramaximal $(10 \mathrm{~V})$ 0.2-ms square wave pulses of $500 \mathrm{~ms}$ at $2 \mathrm{~Hz}$, delivered via two wire electrodes adjacent to the sciatic nerve. To analyze tetanic force, the frequency of electrical stimulus was elevated to $250 \mathrm{~Hz}$. The muscle twitch force (peak of muscle twitch force) and tetanic force (peak of tetanus) were recorded using the Biopac Systems. The muscle strength was analyzed using the AcqKnowledge 3.9.1.6. software.

After completion of all functional tests, the mice were sacrificed by cervical dislocation. The muscles were then excised, weight and prepared for histological analysis, as previous described (Secco et al., submitted). In brief, $10 \mu \mathrm{m}$ muscle cross sections were stained with Hematoxylin \& Eosin (H\&E) as previously described (Dubowitz, 1985). Muscle cross sections were evaluated at 200x magnification and further analyzed on a digitizing unit connected to a computer (Image Pro-plus, Media Cybernetic, Silver Spring, MD, USA). The cross-sectional areas (CSA), centronucleated fibers and interstitium percentage in the muscle were analyzed and quantified in blind test. 


\section{REFERENCES:}

Gang, E.J., Darabi, R., Bosnakovski, D., Xu, Z., Kamm, K.E., Kyba, M., and Perlingeiro, R.C., (2009). Engraftment of mesenchymal stem cells into dystrophin-deficient mice is not accompanied by functional recovery. Exp. Cell Res. 315, 2624-2636.

Ichim, T.E., Alexandrescu, D.T., Solano, F., Lara, F., Campion, R. de N., Paris, E., Woods, E.J., Murphy, M.P., Dasanu, C.A., Patel, A.N., et al (2010). Mesenchymal stem cells as anti-inflammatories: implications for treatment of Duchenne muscular dystrophy. Cell Immunol. 260, 75-82.

Kerkis, I., Ambrosio, C.E., Kerkis, A., Martins, D.S., Zucconi, E., Fonseca, S.A., Cabral, R.M., Maranduba, C.M., Gaiad, T.P., Morini, A.C., et al. (2008). Early transplantation of human immature dental pulp stem cells from baby teeth to golden retriever muscular dystrophy (GRMD) dogs: local or systemic? J. Transl. Med. 6, 35.

Li, Y., Yu, X., Lin, S., Li, X., Zhang, S., and Song YH. (2007). Insulin-like growth factor 1 enhances the migratory capacity of mesenchymal stem cells. Biochem .Biophys. Res. Commun. 356, 780-784.

Pelosi, L., Giacinti, C., Nardis, C., Borsellino, G., Rizzuto, E., Nicoletti, C., Wannenes, F., Battistini, L., Rosenthal, N., Molinaro, M., et al. (2007). Local expression of IGF-1 accelerates muscle regeneration by rapidly modulating inflammatory cytokines and chemokines. FASEB J. 21, 1393-1402.

Quattrocelli, M., Cassano, M., Crippa, S., Perini, I., and Sampaolesi, M. (2010). Cell therapy strategies and improvements for muscular dystrophy. Cell Death Differ. 17, 1222-1229.

Sacco, A., Doyonnas, R., LaBarge, M.A., Hammer, M.M., Kraft, P., and Blau, H.M. (2005). IGF-I increases bone marrow contribution to adult skeletal muscle and enhances the fusion of myelomonocytic precursors. J. Cell Biol. 171, 483492.

Schertzer, J.D., and Lynch, G.S. (2006). Comparative evaluation of IGF-I gene transfer and IGF-I protein administration for enhancing skeletal muscle regeneration after injury. Gene Ther. 13, 1657-1564.

Vieira, N. M., Bueno, C.R. Jr., Brandalise, V., Moraes, L.V., Zucconi, E., Secco, M., Suzuki, M.F., Camargo, M.M., Bartolini, P., Brum, P.C., et al. (2008). Sjl dystrophic mice express a significant amount of human muscle proteins 
following systemic delivery of human adipose-derived stromal cells without immunosupression. Stem Cells 26, 2391-2398.

Vieira, N. M., Valadares, M., Zucconi, E., Secco, M., Bueno, C.R. Jr., Brandalise, V., Assoni, A., Gomes, J., Landini, V., Andrade, T., et al. (2011). Human Adipose-Derived Mesenchymal Stromal cells injected systemically into GRMD dogs without immunosupression are able to reach the host muscle and express human dystrophin. Cell Transplant. [Epub ahead of print].

Vieira, N.M., Zucconi, E., Bueno, C.R. Jr., Secco, M., Suzuki, M.F., Bartolini, P., Vainzof, M., and Zatz, M. (2010) Human multipotent mesenchymal stromal cells from distinct sources show different in vivo potential to differentiate into muscle cells when injected in dystrophic mice. Stem Cell Rev. 6, 560-566.

Wagner, J., Kean, T., Young, R., Dennis, J.E., and Caplan, A.I. (2009). Optimizing mesenchymal stem cell-based therapeutics. Curr Opin Biotechnol. 20, 531-536.

\section{Tables and Figures}

\section{Figure Legends}

Figure 1: Association of local IGF-1 and MSCs did not improve skeletal muscular strength in LAMA2 ${ }^{d y / 2 j}$ dystrophic mice. (A) Grip Force indicated as performance variation before and after the treatments $(B, C)$ Muscle Twitch and Tetanic Force determined at $1 \mathrm{~Hz}$ and $250 \mathrm{~Hz}$ of electrical stimulus frequency, respectively, in non-dystrophic mice (CNT; $n=21)$; untreated dystrophic mice (U; $n=11$ ), MSC treated mice (MSC; $n=13$ ) IGF-1 treated mice (local IGF-1; $n=9$ ), and both local IGF-1 and MSC treated mice $(n=9)$. As control, vehicle solution alone was injected into the contralateral leg (vehicle) of animals treated with local IGF-1. Twitch and Tetanic Forces were normalized to body mass. Data are 
presented as mean $\pm \mathrm{SE} .{ }^{*} \mathrm{P}<0.05$ versus untreated and treated dystrophic mice; ${ }^{\#} \mathrm{P}<0.05$ versus untreated dystrophic mice; Student's $t$ test.

Figure 2: Association of both MSCs and IGF-1 did not cause muscular hypertrophy, neither reduces fibrosis in LAMA2 ${ }^{d y / 2 j}$ dystrophic muscle. (AG) Representative H\&E-stained cross sections of Tibialis Anterior (TA) muscle from non-dystrophic mice (CNT); untreated LAMA2 ${ }^{d y / 2 j}$ dystrophic mice (untreated), MSC treated mice (MSC), local IGF-1 treated mice (local IGF-1), and both local IGF-1 and MSC treated mice. As control, vehicle solution alone was injected into the contralateral leg (vehicle) of animals treated with local IGF1; (H-K) Diagram showing the quantitative analysis of Tibialis Anterior (TA) muscle Mass, Cross-Sectional Area (CSA), Centronucleated Fibers and Interstitium percentage of muscle from non-dystrophic mice (CNT); untreated LAMA2 $2^{d y / 2 j}$ dystrophic mice (untreated), MSC treated mice (MSC), local IGF-1 treated mice (local IGF-1), and both local IGF-1 and MSC treated mice. TA muscle mass was normalized to body mass. The data are presented as mean \pm SE $(n=4) .{ }^{*} P<0.05$ versus untreated and treated dystrophic mice; Student's $t$ test. 
TABLE 1. Basic Parameters of dystrophic LAMA2 ${ }^{d y / 2 j}$ mice after treatment with local IGF-1 and MSC

\begin{tabular}{lccccc}
\hline \hline & $\begin{array}{c}\text { Control } \\
(\mathrm{n}=7)\end{array}$ & $\begin{array}{c}\text { Untreated } \\
(\mathrm{n}=7)\end{array}$ & $\begin{array}{c}\text { MSC } \\
(\mathrm{n}=8)\end{array}$ & $\begin{array}{c}\text { Iocal IGF-1 } \\
(\mathrm{n}=8)\end{array}$ & $\begin{array}{c}\text { Iocal IGF-1+MSC } \\
(\mathrm{n}=8)\end{array}$ \\
\hline & & & & & \\
Body mass (g) & $25.34 \pm 0.78^{\star}$ & $20.61 \pm 0.70$ & $18.98 \pm 0.39 \star \star \star$ & $20.27 \pm 0.94$ & $19.45 \pm 0.64$ \\
Heart mass/body mass (mg/g) & $4.60 \pm 0.13^{\star \star}$ & $4.97 \pm 0.12$ & $5.16 \pm 0.28$ & $4.89 \pm 0.37$ & $4.99 \pm 0.09$ \\
Liver mass/body mass (mg/g) & $52.55 \pm 1.87^{*}$ & $55.96 \pm 2.58$ & $55.35 \pm 2.03$ & $55.09 \pm 2.68$ & $53.37 \pm 2.72$ \\
& & & & & \\
\hline
\end{tabular}

The number of animals in each group is shown in parentheses and the data are presented as mean \pm SE. Heart and liver mass was normalized to body mass. Data are presented as mean $\pm \mathrm{SE} .{ }^{*} \mathrm{P}<0.05$ versus untreated and treated LAMA2 ${ }^{d y / 2 j}$ dystrophic mice, ${ }^{* *} \mathrm{P}<0.05$ versus nondystrophic mice (CNT) and untreated dystrophic mice; Student's $t$ test. 


\section{FIGURE 1}

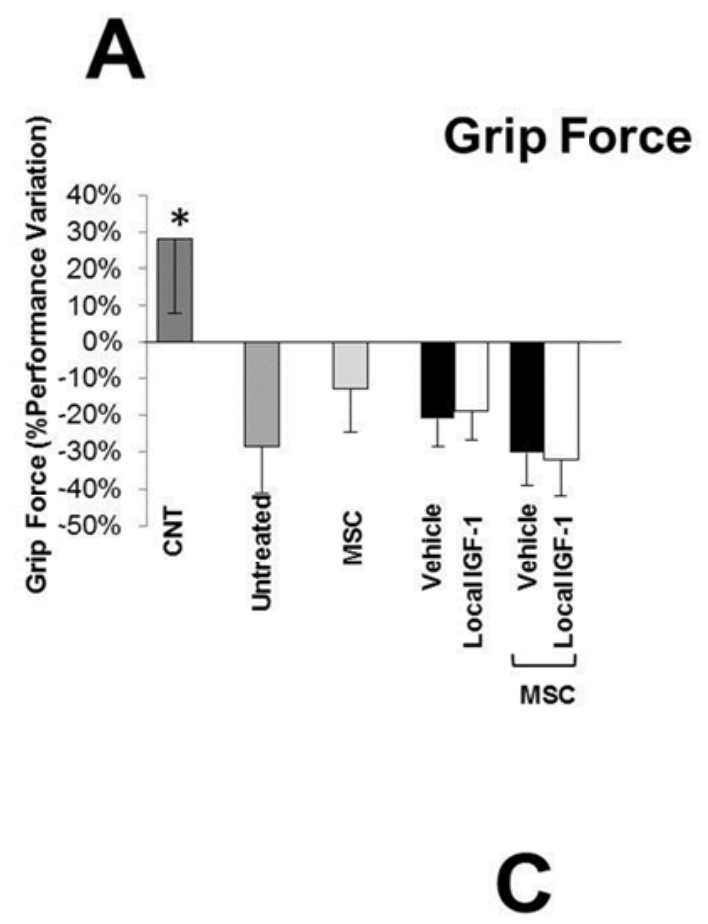

\section{Twitch Force}

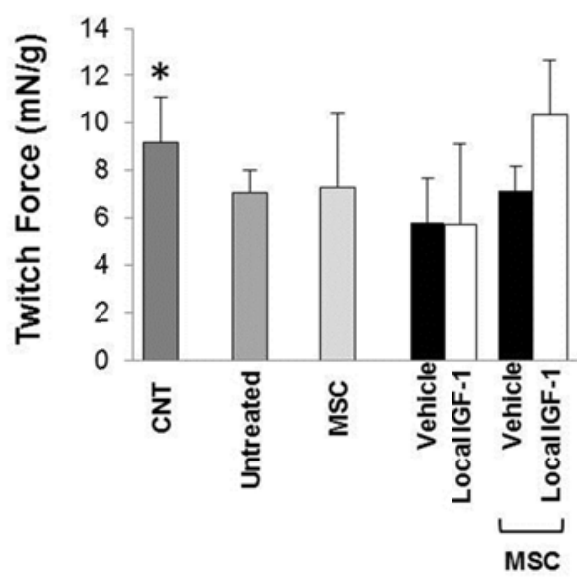

Tetanic Force

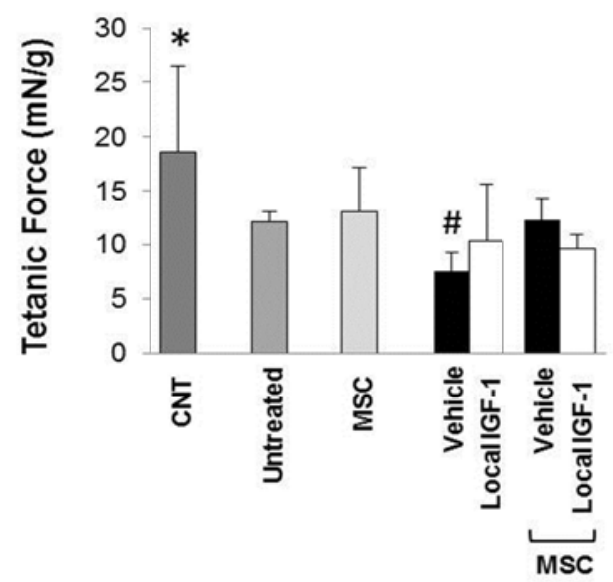


FIGURE 2
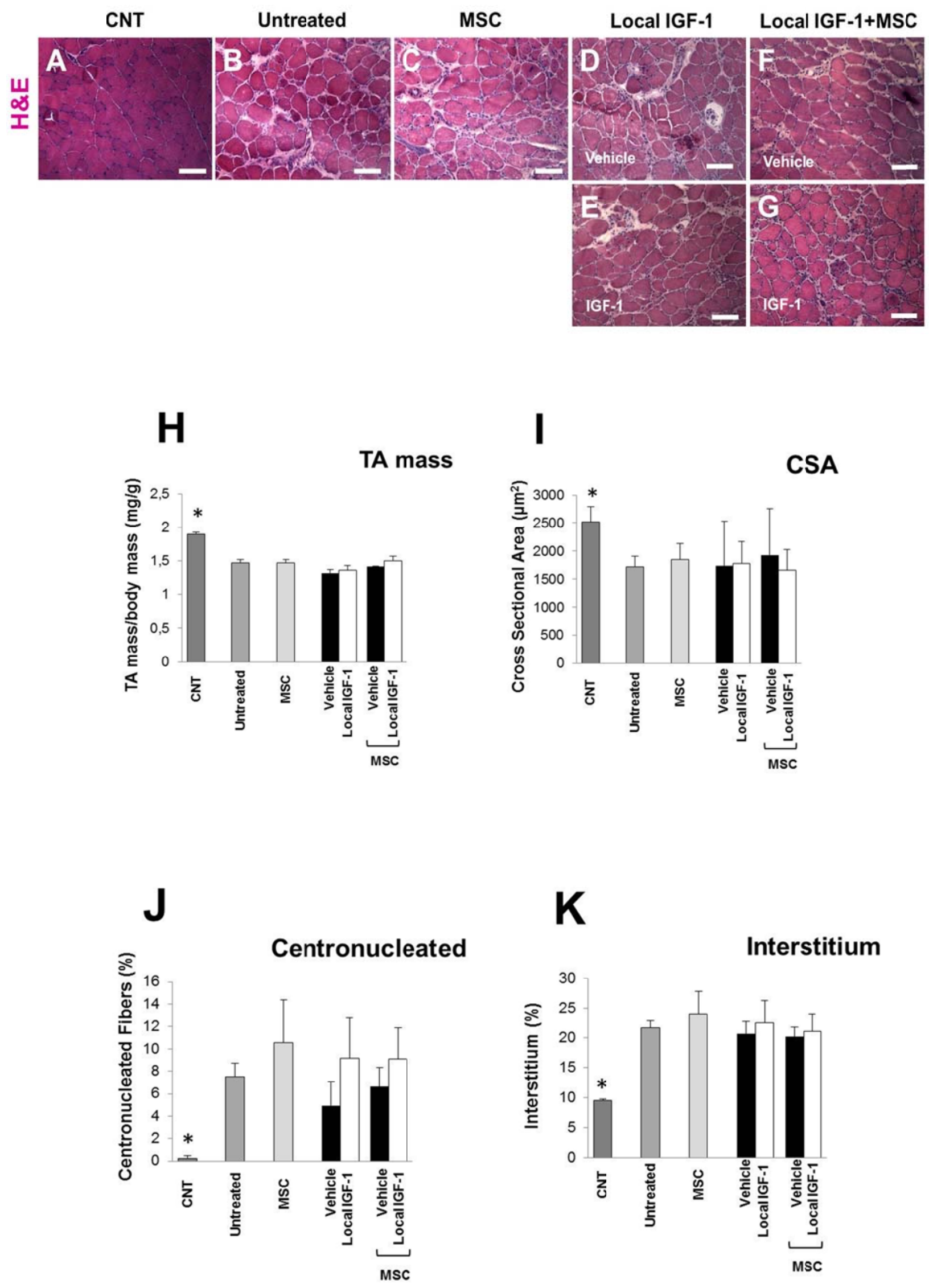


\section{Capítulo 7}

\section{I - DISCUSSÃO GERAL}

Até o presente momento nenhuma terapia eficaz está disponível para os pacientes com diferentes tipos de distrofias musculares progressivas (PMDs, do inglês Progressive Muscular Dystrophies). Desta forma, a avaliação do potencial terapêutico de células-tronco e a otimização dos protocolos de terapia celular são alvos de estudo em diversos centros de pesquisas.

Um dos desafios imediatos no âmbito da terapia celular é a identificação de fontes abundantes e acessíveis de células-tronco. Na primeira etapa do nosso estudo, comparamos a eficiência do isolamento de célulastronco mesenquimais ou células estromais mesenquimais (MSCs, do inglês Mesenchymal Stem Cells) do sangue e do tecido do cordão umbilical humano de amostras pareadas, ou seja, obtidas do mesmo doador, processadas simultaneamente e cultivadas nas mesmas condições (CAPÍTULO 2). Nossos resultados mostraram que não o sangue e sim o tecido do cordão umbilical é rico em MSCs (Secco et al., 2008a,b). Além de serem facilmente isoladas, as MSCs do tecido do cordão apresentam um amplo potencial de expansão in vitro e manutenção da viabilidade e características após congelamento e descongelamento. Uma vez que a rotina nos bancos públicos e/ou privados de cordão é guardar o sangue e descartar outras fontes biológicas como o tecido do cordão umbilical e placenta, alertamos a população e a comunidade científica sobre os resultados obtidos em nossos estudos. Visto que as MSCs têm sido consideradas uma das grandes promessas para a medicina regenerativa, os dados encontrados aqui são de extrema importância.

Igualmente relevantes são os resultados obtidos com a comparação do perfil de expressão gênica das amostras pareadas de MSCs humanas de sangue e tecido de cordão umbilical (CAPÍTULO 3). Nossos dados mostraram que as MSCs de tecido de cordão umbilical apresentam uma maior expressão de genes relacionados com adesão celular, angiogênese e neurogênese, 
enquanto que aquelas obtidas de sangue de cordão umbilical apresentaram uma maior expressão de genes relacionados com sistema imune e osteogênese (Secco et al., 2009). As diferenças encontradas aqui sugerem que o nicho tecidual exerce influência nas características das células. Resultados similares haviam sido previamente reportados por outros grupos (Pannepuci et al., 2004; Wagner et al., 2005; Kern et al., 2007; Tsai et al., 2007; Kim et al., 2011). Por exemplo, Pannepuci et al. (2004) demonstraram que MSCs de medula óssea e cordão umbilical apresentavam diferenças em relação ao perfil de expressão gênica, sendo que aquelas derivadas de medula óssea estariam mais comprometidas com linhagens osteoblásticas e adipocíticas, enquanto que as derivadas da veia de cordão umbilical estariam relacionadas a funções ligadas à angiogênese ou vasculogênese. Cabe salientar, entretanto, que as diferenças relatadas por estes estudos podem também refletir a variabilidade entre indivíduos visto que as amostras analisadas foram obtidas de diferentes doadores, ao passo que nos nossos estudos as comparações foram conduzidas com amostras pareadas.

A análise comparativa de MSCs é de grande relevância, uma vez que pode contribuir para uma melhor compreensão das diferenças entre células-tronco e suas implicações na escolha da mais adequada para diferentes aplicações na terapia celular. A expressão de genes relacionados com a neurogênese, por exemplo, é um ponto favorável à aplicação de MSCs de tecido de cordão umbilical em modelos de doenças neurológicas. De fato, um trabalho dirigido pelo professor Oswaldo Keith Okamoto demonstrou que MSCs de tecido de cordão umbilical humano foram capazes de promover efeitos benéficos em modelos experimentais de doença de Parkinson (Pereira et al., 2007). Estes dados ressaltam a importância de compararmos detalhadamente $o$ potencial miogênico de MSCs obtidas de diferentes fontes, que poderia determinar a efetividade dos transplantes em casos de distrofias musculares (projeto de doutorado em andamento; responsável: Marcos Valadares).

Neste sentido, outra questão importante relativa ao uso de célulastronco para o tratamento de distrofias musculares diz respeito à otimização da 
indução da diferenciação miogênica de MSCs. A grande maioria das metodologias já descritas baseia-se no tratamento in vitro das MSCs com morfógenos e/ou fatores de crescimento isolados ou em combinação, tentando reproduzir processos que ocorrem durante o desenvolvimento. Os protocolos mais bem estabelecidas utilizam estímulos já conhecidos para indução da diferenciação para músculo esquelético, tais como administração de 5azacitidina (5-AZA), dexametasona, e baixas concentrações de soro nos meios de cultivo, mais especificamente pelo uso de soro de cavalo (Choi et al., 2004; Zuk et al., 2001; Vieira et al., 2008a). Entretanto, estas substâncias são agentes de diferenciação não específicos, utilizadas também no direcionamento para outros tipos celulares, o que compromete a pureza da população obtida. Além disso, estes estudos foram feitos, em sua maioria, pela adição de fatores de crescimento isolados, apresentando algumas limitações devido à falta de fatores permissivos ou repressivos que possivelmente estariam presentes in vivo e que poderiam influenciar o potencial das células. De fato, a maioria dos protocolos de diferenciação miogênica reportados para as MSCs foram ineficientes.

No presente estudo, duas abordagens de indução de miogênese em MSCs foram descritas (CAPÍTULO 4 e 5). Primeiramente, utilizamos meios condicionados obtidos do músculo de camundongos distróficos $m d x$ e LAMA $^{d y / 2 j}$, visto que os fatores solúveis liberados em decorrência da lesão são candidatos a exercerem o estímulo necessário para a indução da diferenciação miogênica de células precursoras. Trabalhos anteriores reportaram que a exposição de MSCs de rato a meio condicionado de músculo quimicamente lesionado promovia sua diferenciação miogênica (Santa María et al., 2004). Portanto, o mesmo modelo de lesão química foi padronizado no músculo de camundongos e, posteriormente, os meios condicionados foram preparados e utilizados como controle positivo da diferenciação (CAPÍTULO 4). Além de otimizar os protocolos de diferenciação miogênica de MSCs, o uso dos meios condicionados facilita a identificação dos fatores solúveis presentes no músculo distrófico que poderiam influenciar o potencial miogênico in vivo de MSCs. 
Embora alguns trabalhos já tenham demonstrado que o microambiente in vivo exerce influência sobre as células-tronco (Gharaibeh et al., 2011), ensaios in vitro devem ser realizados com o intuito de entender isoladamente os efeitos dos fatores tróficos liberados no músculo sobre a capacidade de proliferação e diferenciação miogênica de células-tronco.

Nossos resultados demonstraram que somente os fatores solúveis liberados do músculo de camundongos $m d x$ foram capazes de induzir a diferenciação miogênica terminal das MSCs, conforme verificado pela baixa expressão de marcadores miogênicos iniciais, tais como MyoD, e níveis elevados de marcadores miogênicos tardios, incluindo Desmina e MyHC (do inglês Myosin Heavy Chain). Com o intuito de identificar alguns dos fatores envolvidos com estes efeitos, a concentração de IGF-1 (do inglês Insulin-like Growth Factor 1) e TGF- $\beta$ (do inglês Transforming Growth Factor- $\beta$ ) foi quantificada nos respectivos meios condicionados, dada a sua importância no processo de regeneração muscular; as funções do IGF-1 incluem, o aumento da proliferação, diferenciação e fusão de células satélites (Mourkioti and Rosenthal, 2005), enquanto que os fatores da família TGF- $\beta$ estão envolvidos na inibição da diferenciação miogênica e aumento na produção de tecido fibrótico (Tidball et al., 2005; Schabort et al., 2011; Gardner et al., 2011).

Segundo os dados apresentados no CAPÍTULO 4 os níveis de IGF-1 encontram-se elevados nos camundongos $m d x$, o que pode estar associado à elevada capacidade regenerativa encontrada no músculo destes animais. Além disso, a eficiente indução da diferenciação miogênica reportada após cultivo de MSCs em meios condicionados obtidos com músculo de camundongos $m d x$ pode estar associada à alta concentração de IGF-1.

Embora o músculo dos camundongos submetidos à lesão química também tenha apresentado altos níveis de IGF-1, a sua concentração de TGF- $\beta$ é igualmente elevada. Sabe-se que o ambiente muscular após uma lesão é caracterizado pela presença de fatores permissivos e repressivos à ativação e diferenciação de progenitores musculares, que são coordenados 
temporalmente e dependentes de concentração adequada durante o processo de regeneração (Mourkioti and Rosenthal, 2005). Visto que os meios condicionados com músculo destes animais não foram capazes de induzir a miogênese terminal de MSCs com tanta eficiência quanto aqueles obtidos do músculo de camundongos $m d x$, é provável que, neste caso, os efeitos do TGF$\beta$ tenham se contraposto aos efeitos do IGF-1. Além disso, visto que estes meios condicionados foram preparados com apenas dois dias após a lesão ser induzida, é possível que o processo de reparo do músculo esteja em etapas iniciais de ativação e proliferação de células satélites. De fato, nossos resultados mostraram que os meios condicionados preparados a partir do músculo quimicamente lesionado são capazes de aumentar significativamente a proliferação de MSCs em comparação à condição controle (CAPÍTULO 4).

A importância dos fatores solúveis IGF-1 e TGF- $\beta$ no processo de reparo do músculo torna-se mais evidente quando analisamos sua concentração nos animais LAMA2 ${ }^{d y / 2 j}$. Ao contrário do observado nos camundongos $m d x$, o músculo dos modelos distróficos LAMA2 $2^{d y / 2 j}$ apresenta baixos níveis de IGF-1, ao passo que, a concentração de TGF- $\beta$ é elevada. Esses achados estão de acordo com o fenótipo grave exibido por estes animais, cujo músculo apresenta predominância de degeneração e fibrose. A baixa eficiência da diferenciação miogênica de MSCs cultivadas em meios condicionados obtidos a partir de músculos LAMA2 ${ }^{d y / 2 j}$ também parece estar associada aos níveis de IGF-1 e TGF- $\beta$.

Outros trabalhos já haviam demonstrado que o IGF-1 contribui ativamente para o reparo do músculo em condições patológicas, como no caso de distrofias musculares. Em cães distróficos os níveis de IGF-1 parecem estar associados à gravidade do quadro clínico: dados referentes à dosagem sérica revelaram uma maior concentração deste fator de crescimento nos animais portadores da forma clínica benigna em relação aos animais com quadro clínico grave (De Lima et al., 2007). Além disso, em camundongos $m d x$ já havia sido reportado a alta concentração de IGF-1 na musculatura esquelética (De Luca et al., 1999). Sendo assim, os dados mostrados aqui são mais uma evidência de 
que o microambiente interfere na capacidade regenerativa do músculo e está relacionado com o fenótipo dos modelos murinos $m d x$ e LAMA2 $2^{d y / 2 j}$. Nesse sentido, a identificação de alguns dos fatores solúveis presentes nesses microambientes também foi de extrema importância, pois sua manipulação poderá constituir uma estratégia terapêutica atraente no combate da degeneração muscular grave em situações patológicas. Além disso, a informação de que o músculo distrófico influencia o potencial miogênico de MSCs deve ser considerada para o planejamento de futuros protocolos de terapia celular em casos de distrofias musculares.

Dada a sua importância no processo de reparo muscular, um segundo protocolo utilizado para a indução da diferenciação miogênica de MSCs consistiu do seu cultivo em meios suplementados com IGF-1 em diferentes concentrações (CAPÍTULO 5). Outros trabalhos já haviam descrito o papel do IGF-1 na proliferação e diferenciação miogênica de células satélites e/ou progenitores musculares (Mourkioti and Rosenthal, 2005). Entretanto estes efeitos nunca haviam sido reportados para as MSCs. Nossos resultados demonstraram que o IGF-1, por si só, foi capaz de promover a diferenciação miogênica de MSCs com mais eficiência que os protocolos padrões comumente utilizados. Além disso, nós verificamos que este fator de crescimento é capaz de aumentar a interação de MSCs com mioblastos e/ou miotubos humanos provenientes de pacientes DMD e reparar a expressão de distrofina, quando em co-culturas (CAPÍTULO 5).

Esses resultados nos motivaram a verificar se a associação da administração de IGF-1 e MSCs seria capaz de promover uma melhora funcional no músculo de modelos murinos (CAPÍTULO 5 e 6). Escolhemos para tal os camundongos distróficos LAMA2 ${ }^{d y / 2 j}$, uma vez que estes animais apresentam um quadro clínico grave, o que facilita a identificação dos benefícios promovidos pelas abordagens terapêuticas experimentais. Além disso, visto que a perda da capacidade regenerativa do músculo destes animais pode estar relacionada aos baixos níveis de IGF-1 reportados aqui (CAPÍTULO 4), a administração exógena desse fator pode constituir uma abordagem 
terapêutica promissora. Em relação à via de administração das células-tronco, como partimos do pressuposto que a distrofia muscular gera efeitos deletérios em uma série de tecidos e/ou órgãos, não sendo restrita à musculatura esquelética, a injeção sistêmica aparece como uma alternativa atraente, além de ser pouco invasiva. A efetividade desse procedimento já foi previamente comprovada em outros ensaios pré-clínicos em modelos animais de distrofias musculares (Sampaolesi et al., 2006; Kerkis et al., 2008; Vieira et al., 2008, 2011; Rouger et al., 2011). Com relação à administração de IGF-1, duas vias distintas foram comparadas. Primeiramente optou-se pela administração sistêmica de um análogo sintético recombinante do IGF-1 - conhecido como LongR3 IGF-1 - por meio de mini-bombas de infusão osmótica, seguindo o mesmo raciocínio previamente utilizado para a escolha da via de administração das MSCs (CAPÍTULO 5). O Long R3-IGF-1 humano apresenta a mesma sequência de aminoácidos do IGF-1 com a substituição de uma arginina por uma glutamina na posição 13, e a adição de 13 aminoácidos na extremidade $\mathrm{N}$ terminal do peptídeo. Segundo dados do fabricante, essas alterações aumentam a eficiência do fator, uma vez que diminuem a ligação do mesmo com proteínas IGFBPs, (do inglês, insulin-like growth factor binding proteins) presentes no soro ou outros fluidos corpóreos, aumentando a concentração de IGF-1 "livre" e, portanto, sua disponibilidade biológica.

Nossos dados mostraram que as MSCs humanas não são rejeitadas após a injeção sistêmica - mesmo sem imunossupressão - e são capazes de migrar para o músculo dos animais distróficos, conforme verificado pela presença de DNA humano. Resultados similares foram reportados após xenotransplantes de MSCs humanas em modelos animais (Kerkis et al., 2008; Vieira et al., 2008; Zucconi et al., 2011; Nitahara-Kasahara et al., 2011). Estudos previamente publicados pelo nosso grupo mostraram que MSCs humanas de cordão umbilical não foram rejeitas após injeção sistêmica em camundongos distróficos SJL e no modelo canino de distrofia muscular (Vieira et al., 2010). Esses achados podem ser explicados, pelo menos em parte, pelo fato das MSCs serem menos imunogênicas e capazes de modular as respostas 
imunes do hospedeiro. Dessa forma, a presença de MSCs de cordão umbilical humano no músculo de camundongos não imunossuprimidos é um ponto favorável à sua aplicação terapêutica em casos de distrofias musculares.

Mais importante, nossos resultados mostraram que a associação da administração sistêmica de IGF-1 e MSCs promoveu uma melhora clínica significativa do músculo dos animais LAMA2 ${ }^{d y / 2 j}$. Considerando que não foi possível detectar a presença de distrofina humana no músculo esquelético dos camundongos injetados com MSCs, mesmo quando associadas ao IGF-1, é plausivel considerar que a melhora funcional reportada não se baseou exclusivamente na diferenciação miogênica direta das células transplantadas. Contudo, visto que a distrofina é um marcador de músculo terminal, não podemos excluir a possibilidade das MSCs se encontrarem em estágios mais precoces do processo de miogênese. Embora nossos resultados tenham demonstrado que o IGF-1 é capaz de aumentar a diferenciação miogênica de MSCs in vitro, esses mesmos resultados não foram obtidos in vivo. É possível que fatores repressivos a miogênese presentes no músculo dos camundongos distróficos tenham afetado o potencial miogênico das MSCs injetadas.

Resultados anteriores também haviam descrito que MSCs de cordão umbilical não foram capazes de expressar distrofina humana no músculo de camundongos distróficos SJL (Vieira et al., 2010). No entanto, nestes ensaios também não foi reportada a melhora funcional do músculo dos animais injetados, mesmo após seis meses de tratamento com MSCs. Comparativamente, no presente estudo, efeitos terapêuticos significativos foram encontrados após dois meses de tratamento, o que sugere um efeito mais potente determinado pela associação de MSCs e IGF-1.

Embora extensivamente estudados, os mecanismos responsáveis pelos efeitos benéficos promovidos pelas MSCs em ensaios pré-clínicos de distrofias musculares ainda não foram elucidados. As abordagens terapêuticas, sobretudo para a Distrofia Muscular de Duchenne (DMD; do inglês Duchenne Muscular Dystrophy), têm analisado o seu sucesso com base na diferenciação 
miogênica e na restauração da distrofina no músculo. Neste sentido, diversos trabalhos têm buscado otimizar os processos de diferenciação miogênica de MSCs por meio da indução da superexpressão de genes envolvidos na miogênese, tais como Pax-3 e MyoD (Gang et al., 2008; Gang et al., 2009; Wagner et al., 2009; Goudenege et al., 2009; Kocaefe et al., 2010; NitaharaKasahara et al., 2011). No entanto, esses mesmos estudos demonstraram que a diferenciação direta in vivo das células não foi acompanhada de melhora funcional do músculo (Gang et al., 2009). Da mesma forma, diversos outros trabalhos têm mostrado que a expressão de distrofina pode não estar associada a uma melhora clínica. Uma ilustração deste fato são os camundongos $m d x$, que apresentam um quadro clínico mais benigno apesar da ausência de distrofina. Um fenótipo mais leve pode também ocorrer, excepcionalmente, em cães GRMDs (Zatz et al., 2010; Zucconi et al., 2010). Corroborando esses achados, mais recentemente foram encontrados cães sem distrofina e com fenótipo normal, da raça Labrador Retriever (LRMD, do inglês Labrador Retriever Muscular Dystrophy; Diane Shelton, comunicação pessoal). Estas observações indicam que o sucesso dos ensaios terapêuticos não deve basear-se unicamente na análise da restauração da expressão da proteína defeituosa no músculo, pois mesmo sem se diferenciar no tecido alvo, as MSCs podem secretar fatores que levem a uma melhora funcional. De fato estudos recentes têm reportado que as MSCs são capazes de secretar uma variedade de citocinas e fatores de crescimento com propriedades anti-inflamatórias e anti-apoptóticas (Caplan and Correa, 2011; Gharaibeh et al., 2011).

Com base nos resultados reportados aqui (CAPÍTULO 5), é mais provável que os benefícios clínicos do co-tratamento de MSCs e IGF-1, administrados sistemicamente, resultem da combinação da secreção parácrina de citocinas e ou fatores de crescimento pelas MSCs e dos efeitos antifibrogênicos, anti-inflamatórios, anti-apoptóticos e pró-regeneração também previamente reportados para o IGF-1 (Mourkioti and Rosenthal, 2005; Pelosi et al., 2007). Cabe ressaltar que os animais LAMA2 ${ }^{d y / 2 j}$ tratados só com célulastronco ou IGF-1 não exibiram melhora funcional do músculo. Neste sentido, é 
provável que o tratamento do músculo pelo IGF-1 tenha favorecido as ações das MSCs. Esses dados reforçam a importância da combinação de diferentes estratégias terapêuticas para o tratamento de distrofias musculares.

Por fim, com base em relatos da literatura que mostram que a administração local de IGF-1 apresenta resultados superiores à sua administração sistêmica em modelos de lesão muscular induzida por toxinas (Schertzer and Lynch, 2006), optamos por testar os efeitos da injeção local de IGF-1 no músculo TA de camundongos LAMA2 ${ }^{\text {dy/2j }}$ (CAPÍTULO 6) em conjunto com a injeção sistêmica de MSCs, seguindo o mesmo esquema de tratamento proposto anteriormente (CAPÍTULO 5). Visto que já foi descrito a influência do IGF-1 no recrutamento de células precursoras para o sítio de lesão (Sacco et al., 2005), é provável que a administração local de IGF-1 favoreça a migração das MSCs para o músculo e maximize os benefícios clínicos dos protocolos de terapia celular.

Nossos dados, contudo, mostraram que a administração local de IGF-1, mesmo quando associada à MSCs, não resultou na melhora clínica dos animais tratados. É possível que sucessivas injeções locais no músculo dos animais causem uma reação inflamatória inesperada que, por fim, culmina na rejeição das MSCs pelo sistema imune do hospedeiro. Além disso, é plausível assumir que injeções intramusculares sucessivas causam uma lesão adicional no músculo distrófico que prejudica o processo de reparo. Experimentos adicionais para confirmar essas hipóteses são de extrema importância e serão posteriormente realizados.

Corroborando nossos achados, outros trabalhos haviam reportado resultados similares em relação à comparação de vias de administração sistêmica e local de MSCs no músculo de cães distróficos GRMDs (Kerkis et al., 2008; Vieira et al., 2011). Por outro lado, Schertzer and Lynch (2006) demonstraram efeitos benéficos da injeção muscular de IGF-1 comparativamente à via sistêmica. Cabe ressaltar, contudo, que neste último estudo foi utilizado um modelo de lesão muscular induzida por miotoxinas, cujo 
dano se resume a um único grupo de músculo. Por outro lado, nos nossos estudos foram utilizados modelos animais de distrofias musculares que, por serem doenças genéticas, causam efeitos deletérios na musculatura do corpo inteiro. Em conjunto, esses dados reforçam a superioridade de métodos terapêuticos sistêmicos, sobretudo nos casos de distrofias musculares.

Embora o presente estudo tenha demonstrado benefícios significativos no quadro clínico de modelos distróficos LAMA2 $2^{d y / 2 j}$ após associação de MSCs humanas derivadas de tecido de cordão umbilical e IGF-1, questões fundamentais ainda persistem e devem ser pesquisadas. No decorrer deste projeto, estudos in vivo conduzidos em nosso laboratório demonstraram que MSCs de tecido adiposo apresentam maior potencial para diferenciação miogênica do que as MSCs de tecido de cordão umbilical (Vieira et al., 2010). Desta forma, novas estratégias baseadas na associação das células de tecido adiposo à IGF-1 em modelos murinos de distrofias musculares serão de extrema importância e surgem como alternativas a serem exploradas em projetos futuros. Além disso, a confirmação destes resultados no modelo canino de distrofia muscular representará um passo importante para o início dos ensaios clínicos em pacientes. 


\section{II - CONCLUSÕES}

1. O tecido do cordão umbilical é a fonte mais rica e de fácil obtenção de MSCs, comparando-se com o sangue do cordão umbilical;

2. MSCs humanas do sangue e do tecido do cordão umbilical, obtidos do mesmo doador, apresentam diferenças no perfil de expressão gênica;

3. MSCs humanas de cordão umbilical são capazes de se diferenciar em células musculares esqueléticas e expressar distrofina in vitro, quando submetidas a dois protocolos distintos de diferenciação miogênica;

4. Fatores solúveis liberados pelo músculo distrófico de camundongos $m d x$ são capazes de induzir a diferenciação miogênica terminal de MSCs humanas de cordão umbilical in vitro;

5. O IGF-1, por si só, é capaz de induzir a diferenciação miogênica terminal de MSCs humanas de cordão umbilical in vitro;

6. MSCs humanas de cordão umbilical são capazes de interagir com células musculares de pacientes DMD in vitro, quando cultivadas em meios suplementados com IGF-1;

7. A associação de MSCs humanas de cordão umbilical e IGF-1 promoveu uma melhora clínica significativa em camundongos distróficos LAMA2 $2^{\text {dy/2j; }}$;

8. MSCs humanas do cordão umbilical não são rejeitadas e são capazes de atingir à musculatura de camundongos distróficos LAMA2 $2^{d y / 2 j}$, quando injetadas por via sistêmica em animais não imunossuprimidos; 
9. MSCs humanas de cordão umbilical não foram capazes de expressar a proteína distrofina humana in vivo após injeção em camundongos distróficos LAMA $^{d y / 2 j}$, mesmo quando associadas ao IGF-1;

10. Os benefícios clínicos observados pelo tratamento conjunto de MSCs humanas de cordão umbilical e IGF-1 são resultado da combinação de ações anti-inflamatórias, anti-fibróticas e pró-regeneração promovidas pelas MSCs e IGF-1. 


\section{III - REFERÊNCIAS BIBLIOGRÁFICAS}

Caplan, A.I., and Correa, D. (2011). The MSC: an injury drugstore. Cell Stem Cell 9, 11-15.

Choi, S.C., Yoon, J., Shim, W.J., Ro, Y.M., and Lim, D.S.(2004). 5-azacytidine induces cardiac differentiation of P19 embryonic stem cells. Exp. Mol. Med. 36, 515-523.

De Lima, A.R., Nyengaard, J.R., Jorge, A.A., Balieiro, J.C., Peixoto, C., Fioretto, E.T., Ambrósio, C.E., Miglino, M.A., Zatz, M., and Ribeiro A.A. (2007). Muscular dystrophy-related quantitative and chemical changes in adenohypophysis $\mathrm{GH}$ cells in golden retrievers. Growth Horm. IGF Res. 17, 480-491.

De Luca, A., Pierno, S., Camerino, C., Cocchi, D., and Camerino, D.C. (1999). Higher content of insulin-like growth factor-I in dystrophic $\mathrm{mdx}$ mouse: potential role in the spontaneous regeneration through an electrophysiological investigation of muscle function. Neuromuscul. Disord. 9, 11-18.

Gang, E.J., Bosnakovski, D., Simsek, T., To, K., and Perlingeiro, R.C. (2008). Pax3 activation promotes the differentiation of mesenchymal stem cells toward the myogenic lineage. Exp. Cell Res. 314, 1721-1733.

Gang, E.J., Darabi, R., Bosnakovski, D., Xu, Z., Kamm, K.E., Kyba, M., and Perlingeiro, R.C., (2009). Engraftment of mesenchymal stem cells into dystrophin-deficient mice is not accompanied by functional recovery. Exp. Cell Res. 315, 2624-2636.

Gardner, S., Alzhanov, D., Knollman, P., Kuninger, D., and Rotwein, P. (2011). TGF- $\beta$ inhibits muscle differentiation by blocking autocrine signaling pathways initiated by IGF-II. Mol. Endocrinol. 25, 128-137.

Gharaibeh, B., Lavasani, M., Cummins, J.H., and Huard, J. (2011). Terminal differentiation is not a major determinant for the success of stem cell therapy - cross-talk between muscle-derived stem cells and host cells. Stem Cell Res. Ther. 2, 31.

Goudenege, S., Pisani, D.F., Wdziekonski, B., Di Santo, J.P., Bagnis, C., Dani, C., and Dechesne, C.A. (2009). Enhancement of myogenic and muscle repair capacities of human adipose-derived stem cells with forced expression of MyoD. Mol. Ther. 17, 1064-1072.

Kerkis, I., Ambrosio, C.E., Kerkis, A., Martins, D.S., Zucconi, E., Fonseca, S.A., Cabral, R.M., Maranduba, C.M., Gaiad, T.P., Morini, A.C., et al. (2008). Early transplantation of human immature dental pulp stem cells from baby teeth to golden retriever muscular dystrophy (GRMD) dogs: local or systemic? J. Transl. Med. 6, 35. 
Kern, S., Eichler, H., Stoeve, J., Klüter, H., and Bieback, K. (2006). Comparative analysis of mesenchymal stem cells from bone marrow, umbilical cord blood, or adipose tissue. Stem Cells 24, 1294-1301.

Kim, S.H., Kim, Y.S., Lee, S.Y., Kim, K.H., Lee, Y.M., Kim, W.K., and Lee, Y.K. (2011). Gene expression profile in mesenchymal stem cells derived from dental tissues and bone marrow. J. Periodontal Implant. Sci. 41, 192-200.

Kocaefe, C., Balci, D., Hayta, B.B., and Can, A. (2010). Reprogramming of human umbilical cord stromal mesenchymal stem cells for myogenic differentiation and muscle repair. Stem Cell Rev. 6, 512-522.

Mourkioti, F., and Rosenthal, N. (2005). IGF-1, inflammation and stem cells: interactions during muscle regeneration. Trends Immunol. 26, 535-42.

Nitahara-Kasahara, Y., Hayashita-Kinoh, H., Ohshima-Hosoyama, S., Okada, H., Wada-Maeda, M., Nakamura, A., Okada, T., and Takeda S. (2011). Longterm Engraftment of Multipotent Mesenchymal Stromal Cells That Differentiate to Form Myogenic Cells in Dogs With Duchenne Muscular Dystrophy. Mol. Ther. [Epub ahead of print].

Pelosi, L., Giacinti, C., Nardis, C., Borsellino, G., Rizzuto, E., Nicoletti, C., Wannenes, F., Battistini, L., Rosenthal, N., Molinaro, M., et al. (2007). Local expression of IGF-1 accelerates muscle regeneration by rapidly modulating inflammatory cytokines and chemokines. FASEB J. 21, 1393-1402.

Pereira, M.C., Secco, M., Suzuki, D.E., Janjoppi, L., Rodini, C.O., Torres, L.B., Araújo, B.H., Cavalheiro, E.A., Zatz, M., and Okamoto, O.K. (2011). Contamination of Mesenchymal Stem-Cells with Fibroblasts Accelerates Neurodegeneration in an Experimental Model of Parkinson's Disease. Stem Cell Rev. [Epub ahead of print].

Rouger, K., Larcher, T., Dubreil, L., Deschamps, J.Y., Le Guiner, C., Jouvion, G., Delorme, B., Lieubeau, B., Carlus, M., Fornasari, B. et al. (2011). Systemic Delivery of Allogenic Muscle Stem (MuStem) Cells Induces Long-Term Muscle Repair and Clinical Efficacy in Duchenne Muscular Dystrophy Dogs. Am. J. Pathol. [Epub ahead of print].

Sacco, A., Doyonnas, R., LaBarge, M.A., Hammer, M.M., Kraft, P., and Blau, H.M. (2005). IGF-I increases bone marrow contribution to adult skeletal muscle and enhances the fusion of myelomonocytic precursors. J. Cell Biol. 171, 483492.

Sampaolesi, M., Blot, S., D'Antona, G., Granger, N., Tonlorenzi, R., Innocenzi, A., Mognol, P., Thibaud, J.L., Galvez, B.G., Barthélémy, I., et al. (2006). 
Mesoangioblast stem cells ameliorate muscle function in dystrophic dogs. Nature 444, 574-579.

Santa María, L., Rojas, C.V., and Minguell, J.J. (2004). Signals from damaged but not undamaged skeletal muscle induce myogenic differentiation of rat bonemarrow-derived mesenchymal stem cells. Exp. Cell Res. 300, 418-426.

Schabort, E.J., Van der Merwe, M., and Niesler, C.U. (2011). TGF- $\beta$ isoforms inhibit IGF-1-induced migration and regulate terminal differentiation in a cellspecific manner. J. Muscle Res. Cell Motil. 31, 359-367.

Schertzer, J.D., and Lynch, G.S. (2006). Comparative evaluation of IGF-I gene transfer and IGF-I protein administration for enhancing skeletal muscle regeneration after injury. Gene Ther. 13, 1657-1564.

Secco, M., Moreira, Y.B., Zucconi, E., Vieira, N.M., Jazedje, T., Muotri, A.R., Okamoto, O.K., Verjovski-Almeida, S., and Zatz, M. (2009). Gene expression profile of mesenchymal stem cells from paired umbilical cord units: cord is different from blood. Stem Cell Rev. 5, 387-401.

Secco, M., Zucconi, E., Vieira, N.M., Fogaça, L.L., Cerqueira, A., Carvalho, M.D., Jazedje, T., Okamoto, O.K., Muotri, A.R., and Zatz, M. (2008a). Multipotent stem cells from umbilical cord: cord is richer than blood! Stem Cells $26,146-150$.

Secco, M., Zucconi, E., Vieira, N.M., Fogaça, L.L., Cerqueira, A., Carvalho, M.D., Jazedje, T., Okamoto, O.K., Muotri, A.R., and Zatz, M. (2008b). Mesenchymal stem cells from umbilical cord: do not discard the cord! Neuromuscul. Disord. 18, 17-18.

Silva, W.A. Jr., Covas, D.T., Panepucci, R.A., Proto-Siqueira, R., Siufi, J.L., Zanette, D.L., Santos, A.R., and Zago, M.A. (2003). The profile of gene expression of human marrow mesenchymal stem cells. Stem Cells 21, 661-669.

Tidball, J.G. (2005). Inflammatory processes in muscle injury and repair. Am. J. Physiol. Regul. Integr. Comp. Physiol. 288, 345-353.

Tsai, M.S., Hwang, S.M., Chen, K.D., Lee, Y.S., Hsu, L.W., Chang, Y.J., Wang, C.N., Peng, H.H., Chang, Y.L., Chao, A.S., et al. (2007). Functional network analysis of the transcriptomes of mesenchymal stem cells derived from amniotic fluid, amniotic membrane, cord blood, and bone marrow. Stem Cells 25, 25112523.

Vieira, N.M., Bueno, C.R. Jr., Brandalise, V., Moraes, L.V., Zucconi, E., Secco, M., Suzuki, M.F., Camargo, M.M., Bartolini, P., Brum, P.C., et al. (2008). Sjl dystrophic mice express a significant amount of human muscle proteins following systemic delivery of human adipose-derived stromal cells without immunosupression. Stem Cells 26, 2391-2398. 
Vieira, N.M., Valadares, M., Zucconi, E., Secco, M., Bueno, C.R. Jr., Brandalise, V., Assoni, A., Gomes, J., Landini, V., Andrade, T., et al. (2011). Human Adipose-Derived Mesenchymal Stromal cells injected systemically into GRMD dogs without immunosupression are able to reach the host muscle and express human dystrophin. Cell Transplant. [Epub ahead of print].

Vieira, N.M., Brandalise, V., Zucconi, E., Jazedje, T., Secco, M., Nunes, V.A., Strauss, B.E., Vainzof, M., and Zatz, M. (2008a). Human multipotent adiposederived stem cells restore dystrophin expression of Duchenne skeletal-muscle cells in vitro. Biol. Cell. 100, 231-41.

Vieira, N.M., Zucconi, E., Bueno, C.R. Jr., Secco, M., Suzuki, M.F., Bartolini, P., Vainzof, M., and Zatz, M. (2010) Human multipotent mesenchymal stromal cells from distinct sources show different in vivo potential to differentiate into muscle cells when injected in dystrophic mice. Stem Cell Rev. 6, 560-566.

Wagner, J., Kean, T., Young, R., Dennis, J.E., and Caplan, A.I. (2009). Optimizing mesenchymal stem cell-based therapeutics. Curr. Opin. Biotechnol. 20, 531-536.

Wagner, W., Wein, F., Seckinger, A., Frankhauser, M., Wirkner, U., Krause, U., Blake, J., Schwager, C., Eckstein, V., Ansorge, W., and Ho, A.D. (2005). Comparative characteristics of mesenchymal stem cells from human bone marrow, adipose tissue, and umbilical cord blood. Exp. Hematol. 33, 1402-1416.

Zatz, M., Zucconi, E., Valadares, M., and Jazedje T. (2010). Phenotypes in golden retriever. Neuromuscul. 20, 71.

Zucconi, E., Valadares, M.C., Vieira, N.M., Bueno, C.R. Jr., Secco, M., Jazedje, T., Da Silva H.C., Vainzof, M., and Zatz M. (2010). Ringo: discordance between the molecular and clinical manifestation in a golden retriever muscular dystrophy dog. Neuromuscul. Disord. 2064-2070.

Zucconi, E., Vieira, N.M., Bueno, C.R. Jr., Secco, M., Jazedje, T., Costa Valadares, M., Fussae Suzuki, M., Bartolini, P., Vainzof, M., and Zatz, M. (2011). Preclinical studies with umbilical cord mesenchymal stromal cells in different animal models for muscular dystrophy. J. Biomed. Biotechnol. 2011:715251.

Zuk, P.A., Zhu, M., Mizuno, H., Huang, J., Futrell, J.W., Katz, A.J., Benhaim, P., Lorenz, H.P., and Hedrick, M.H. (2001). Multilineage cells from human adipose tissue: implications for cell-based therapies. Tissue Eng. 7, 211-228. 


\section{Anexo I}

Neuromuscular Disorders 2008; 18:17-18

Mesenchymal stem cells from umbilical cord: do not discard the cord!

Mariane Secco, Eder Zucconi, Natassia M. Vieira, Luciana L. Q. Fogaça, Antonia Cerqueira, Maria Denise Fernandes Carvalho, Tatiana Jazedje, Oswaldo K. Okamoto, Alysson R. Muotri, Mayana Zatz. 


\title{
Mesenchymal stem cells from umbilical cord: Do not discard the cord!
}

\author{
Mariane Secco a,1, Eder Zucconi ${ }^{\text {a, }}{ }^{\text {, }}$, Natassia M. Vieira ${ }^{\text {a }}$, Luciana L.Q. Fogaça ${ }^{\text {a }}$, \\ Antonia Cerqueira ${ }^{a}$, Maria Denise F. Carvalho ${ }^{a}$, Tatiana Jazedje ${ }^{a}$, Oswaldo K. Okamoto ${ }^{b}$, \\ Alysson R. Muotri ${ }^{c}$, Mayana Zatz ${ }^{\mathrm{a}, *}$ \\ ${ }^{a}$ Human Genome Research Center, Department of Genetic and Evolutive Biology, University of São Paulo, São Paulo, SP, Brazil \\ ${ }^{\mathrm{b}}$ Department of Neurology and Neurocirurgy, Federal University of São Paulo, São Paulo, SP, Brazil \\ ${ }^{\mathrm{c}}$ Laboratory of Genetic, The Salk Institute for Biological Studies, 10010 North Torrey Pines Road, La Jolla, CA 92037, USA
}

Received 27 October 2007; accepted 19 November 2007

Keywords: Human umbilical cord; Human umbilical cord blood; Mesenchymal stem cells; Umbilical cord banks

On 10th February 2007, English entrepreneur Sir Richard Branson, best known for his Virgin brand of over 360 companies, announced the establishment of a cord blood bank, the Virgin Health Bank, in London. What makes this bank different is a dual public-private approach. A fifth of the cord blood would be stored for private use for the child or a family member and the rest would be donated to the public part of the bank which will be accessible to anyone in the world who needs it, at no cost. Additionally, Branson has pledged to donate his $50 \%$ of proceeds from Virgin Health Bank to researchers investigating the potential of cord blood stem cells [1].

The idea for the dual bank emerged when he was visited by a senior director of the National Blood Center, asking for his support in a charitable role, because children were dying through lack of umbilical cord blood. Initially Sir Richard offered 3 million pounds to the National Health Service to help them increase their storage capacity for umbilical cord blood, but the center was not comfortable with accepting funds from private sources. So Sir Richard decided to set up a company to do the job.

This is an initiative that should be applauded but we want to draw attention to a very important and urgent aspect. The routine procedure in umbilical cord banks has been to store the blood and discard other tissues, such as the cord and/or placenta, which is a much better source of mesenchymal stem cells than blood [2]. Umbilical cord

\footnotetext{
* Corresponding author.

E-mail address: mayazatz@usp.br (M. Zatz).

${ }^{1}$ These authors contributed equally to this work.
}

blood is rich in haematopoietic stem cells [3-6]. However the successful isolation of mesenchymal stem cells, which are undifferentiated cells able to self-renew, with high proliferative capacity, from the cord blood is controversial [713]. These cells comprise a rare population of multipotent precursors that in addition to supporting haematopoiesis are able to differentiate into various cell types such as chondrocytes, osteocytes, adipocytes and myocytes [14-17].

Bone marrow has been considered as one of the main sources of mesenchymal stem cells for both experimental and clinical applications and most of the knowledge concerning these cells came from bone marrow studies. However, obtaining them is painful and yields a low number of cells $[18,19]$. More recently, human umbilical cord blood taken after full term delivery of the newborn, from a sample that would be inevitably discarded has been regarded as an alternative source for transplantation and therapy because of its haematopoietic and mesenchymal components. However, while some researchers succeeded in the isolation of mesenchymal stem cells from umbilical cord blood [7-10] others failed or obtained low yield [11-13]. More recently, some groups have reported success in isolating and establishing mesenchymal stem cells cultures from umbilical cord vein and UC stroma, also called Wharton's jelly $[11,16,20,21]$. According to Tondreau et al. [22], these discrepant results might be explained by different isolation and culture methodologies.

In order to address this question we compared, for the first time, the efficiency in obtaining mesenchymal stem cells from 10 match-paired umbilical cord units harvested from the same donors, where the blood and the cord were 
processed simultaneously and under the same culture conditions [2]. Mesenchymal stem cells from blood were obtained from only one among the 10 cord samples collected but we were able to generate large amounts of primary mesenchymal stem cells cultures from all cord samples, with a $100 \%$ yield, which showed that the low yield of these progenitor cells in umbilical cord blood is not due to different culture methodologies. These results are in accordance with our previous experience where we observed that the efficiency in isolating mesenchymal stem cells from approximately 100 umbilical cord blood units stands around $10 \%$ (unpublished data). These cells isolated by a fast and simple procedure using short enzymatic digestion, may be expanded in vitro, cryogenic stored and thawed [2]. Despite the advantages of umbilical cord blood in haematopoietic reconstitution [3-5], results from our study demonstrated that the umbilical cord and not the blood is the best choice for isolating mesenchymal stem cells for future applications.

Storing umbilical cord blood in private or public banks has been recently the subject of many ethical dilemmas. A great obstacle to the altruistic proposal of Sir Richard Branson to split umbilical cord blood samples in both private and public banks is that the number of cells from one umbilical cord blood unit is usually not sufficient for an adult weighing more than $50 \mathrm{~kg}$, which is a main limiting factor. In short, the important take home message is that regardless of being public or private, these banks are discarding the umbilical cord, a precious source of mesenchymal stem cells. Therefore, we suggest storing both the blood and the umbilical cord, which would allow maximum recovery of hematopoietic and mesenchymal stem cells for possible therapeutic applications in the future. Moreover, the possibility of originating different cell lines obtained from umbilical cord of neonates with malformations or genetic disorders, in particular myogenic lineages from patients with mutations responsible for neuromuscular disorders, may open new avenues for research of vast interest in addition to speed up screening process for therapeutic drugs.

\section{References}

[1] The umbilical cord blood banking Richard Branson's way. Lancet 2007;369:437.

[2] Secco M, Zucconi E, Vieira NM, et al. Multipotent stem cells from umbilical cord: cord is richer than blood! Stem Cells 2007. doi:10.1634/stemcells.2007-0381.

[3] Cohena Y, Nagler A. Hematopoietic stem-cell transplantation using umbilical cord blood. Leuk Lymphoma 2003;44:1287-99.
[4] Ooi J. The efficacy of unrelated cord blood transplantation for adult myelodysplastic syndrome. Leuk Lymphoma 2006;47:599-602.

[5] Laughlin MJ, Barker J, Bamback B, et al. Hematopoietic engraftment and survival in adult recipients of umbilical-cord blood from unrelated donors. N Engl J Med 2001;344:1815-22.

[6] Hayani A, Lampeter E, Viswanatha D, Morgan D, Salvi SN. First report of autologous cord blood transplantation in the treatment of a child with leukemia. Pediatrics 2007;119:296-300.

[7] Lee OK, Kuo TK, Chen WM, Lee KD, Hsieh SL, Chen TH Isolation of multipotent mesenchymal stem cells from umbilical cord blood. Blood 2004;103:1669-75.

[8] Erices A, Conget P, Minguell JJ. Mesenchymal progenitor cells in human umbilical cord blood. Br J Haematol 2000;109:235-42.

[9] Goodwin HS, Bicknese AR, Chien SN, Bogucki BD, Quinn CO, Wall DA. Multilineage differentiation activity by cells isolated from umbilical cord blood: expression of bone, fat and neural markers. Biol Blood Marrow Transplant 2001;7:581-8.

[10] Bieback K, Kern S, Kluter H, Eichler H. Critical parameters for the isolation of mesenchymal stem cells from umbilical cord blood. Stem Cells 2004;22:625-34.

[11] Romanov YA, Svintsitskaya VA, Smirnov VN. Searching for alternative sources of postnatal human mesenchymal stem cells: candidate MSC-like cells from umbilical cord. Stem Cells 2003;21:105-10.

[12] Mareschi K, Biasin E, Piacibello W, Aglietta M, Madon E, Fagioli F. Isolation of human mesenchymal stem cells: bone marrow versus umbilical cord blood. Haematologica 2001;86:1099-100.

[13] Wexler SA, Donaldson C, Denning-Kendall P, Rice C, Bradley B, Hows JM. Adult bone marrow is a rich source of human mesenchymal 'stem' cells but umbilical cord and mobilized adult blood are not. Br J Haematol 2003;121:368-74.

[14] Zuk PA, Zhu M, Ashjian P, et al. Human adipose tissue is a source of multipotent stem cells. Mol Biol Cell 2002;13:4279-95.

[15] Gang EJ, Jeong JA, Hong SH, et al. Skeletal myogenic differentiation of mesenchymal stem cells isolated from human umbilical cord blood. Stem Cells 2004;22:617-24.

[16] Karahuseyinoglu S, Cinar O, Kilic E, et al. Biology of the stem cells in human umbilical cord stroma: in situ and in vitro surveys. Stem Cells 2007;25:319-31.

[17] Kern S, Eichler H, Stoeve J, Kluter H, Bieback K. Comparative analysis of mesenchymal stem cells from bone marrow, umbilical cord blood, or adipose tissue. Stem Cells 2006;24:1294-301.

[18] Mueller SM, Glowacki J. Age-related decline in the osteogenic potential of human bone marrow cells cultured in three-dimensional collagen sponges. J Cell Biochem 2001;82:583-90.

[19] Stenderup K, Justuesen J, Clausen C, Kassem M. Aging is associated with decreased maximal life span and accelerated senescence of bone marrow stromal cells. Bone 2003;33:919-26.

[20] Wang HS, Hung SC, Peng ST, et al. Mesenchymal stem cells in the Wharton's jelly of the human umbilical cord. Stem Cells 2004;22:1330-7.

[21] Sarugaser R, Lickorish D, Baksh D, Hosseini M, Davies JE. Human umbilical cord perivascular (HUCPV) cells: a source of mesenchymal progenitors. Stem Cells 2005;23:220-9.

[22] Tondreau T, Meuleman N, Delforge A, et al. Mesenchymal stem cells derived from CD133-positive cells in mobilized peripheral blood and cord blood: proliferation, Oct4 expression, and plasticity. Stem Cells 2005;23:1105-12. 


\section{Biografia}

Mariane Secco é Bacharel e Licenciada em Ciências Biológicas pela Universidade Presbiteriana Mackenzie (2005). Atualmente é aluna de pósgraduação (Doutorado Direto) do Departamento de Genética e Biologia Evolutiva do Instituto de Biociências da Universidade de São Paulo (2011). Esta tese é apresentada para a obtenção de Titulo de Doutor em Ciências, na área de Biologia/Genética.

\section{Publicações científicas relevantes:}

1. SECCO M, Zucconi E, Vieira NM, Fogaça LL, Cerqueira A, Carvalho MDF, Jazedje T, Okamoto OK, Muotri AR, Zatz M. Multipotent stem cells from umbilical cord: cord is richer than blood! Stem Cells, 26:146-50, 2008.

2. SECCO M, Zucconi E, Vieira NM, Fogaça LL, Cerqueira A, Carvalho MDF, Jazedje T, Okamoto OK, Muotri AR, Zatz M. Mesenchymal stem cells from umbilical cord: Do not discard the cord! Neuromuscul Disord, 18:17-8, 2008.

3. Vieira NM, Brandalis V, Zucconi E, Jazedje T, SECCO $\mathbf{M}$, Nunes VA, Strauss BE, Vainzof M, Zatz M. Human multipotent adipose derived stem cells restore dystrophin expression of Duchenne skeletal muscle cells in vitro. Biol Cell, 100: 231-41, 2008.

4. Vieira NM, Bueno CR Jr, Bradalise V, Moraes LV, Zucconi E, SECCO M, Suzuki MF, Camargo MM,Bartolini P, Brum PC, Vainzof M, Zatz M. Sjl dystrophic mice express a significant amount of human muscle proteins following systemic delivery of human adipose-derived stromal cells without immunosupression. Stem Cells, 26: 2391-8, 2008.

5. SECCO M, Moreira YB, Zucconi E, Vieira NM, Jazedje T, Muotri AR, Okamoto OK, Verjovski-Almeida S, Zatz M. Gene expression profile of mesenchymal stem cells from paired umbilical cord units: cord is different from blood. Stem Cell Rev, 5:387-401, 2009.

6. Jazedje T, SECCO M, Vieira NM, Zucconi E, Gollop TR, Vainzof M, Zatz $M$. Stem cells from umbilical cord blood do have myogenic potential, with and without differentiation induction in vitro. J Trans/ Med, 14:7-6, 2009. 
7. Zucconi E, Vieira NM, Bueno DF, SECCO M, Jazedje T, Ambrosio CE, Passos-Bueno MR, Miglino MA, Zatz M. Mesenchymal stem cells derived from canine umbilical cord vein - a novel source for cell therapy studies. Stem cells Dev, 19:395-402, 2009.

8. Jazedje T, Perin PM, Czeresnia CE, Maluf M, Halpern S, SECCO M, Bueno DF, Vieira NM, Zucconi E, Zatz M. Human fallopian tube: a new source of multipotent adult mesenchymal stem cells discarded in surgical procedures. J Trans/ Med, 7:46, 2009.

9. Vieira NM, Zucconi $E$, Bueno $C R$ Jr, SECCO M, Suzuki MF, Bartolini $P$, Vainzof M, Zatz M. Human multipotent mesenchymal stromal cells from distinct sources show different in vivo potential to differentiate into muscle cells when injected in dystrophic mice. Stem Cell Rev, 6:560-6, 2010.

10. Vieira NM, Brandalise V, Zucconi E, SECCO M, Strauss BE, Zatz M. I solation, characterization, and differentiation potential of canine adiposederived stem cells. Cell Transplant, 19:279-89, 2010.

11. Zucconi E, Valadares MC, Vieira NM, Bueno CR Jr, SECCO M, Jazedje T, da Silva HC, Vainzof M, Zatz M. Ringo: discordance between the molecular and clinical manifestation in a golden retriever muscular dystrophy dog. Neuromuscul Disord, 20:64-70, 2010.

12. Zucconi E, Vieira NM, Bueno CR J r, SECCO M, Jazedje T, Costa Valadares M, Fussae Suzuki M, Bartolini P, Vainzof M, Zatz M. Preclinical studies with umbilical cord mesenchymal stromal cells in different animal models for muscular dystrophy. J Biomed Biotechnol, 2011:715251, 2011.

13. Pereira MC, SECCO M, Suzuki DE, Janjoppi L, Rodini CO, Torres LB, Araújo BH, Cavalheiro EA, Zatz M, Okamoto OK. Contamination of Mesenchymal Stem-Cells with Fibroblasts Accelerates Neurodegeneration in an Experimental Model of Parkinson's Disease. Stem Cell Rev, [Epub ahead of print], 2011.

14. Vieira NM, Valadares $M$, Zucconi E, SECCO M, Bueno CRJ r, Brandalise V, Assoni A, Gomes J, Landini V, Andrade T. et al. (2011). Human Adipose-Derived Mesenchymal Stromal cells injected systemically into GRMD dogs without immunosupression are able to reach the host muscle and express human dystrophin. Cell Transplant, [Epub ahead of print]. 